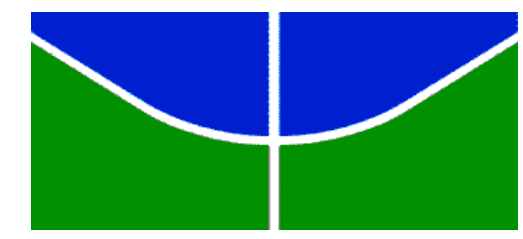

Universidade de Brasília

Centro de Estudos Avançados Multidisciplinares

Programa de Pós-Graduação em Direitos Humanos e Cidadania

\title{
A HISTÓRIA É DE TODOS NÓS: \\ NARRATIVAS SOBRE A FORMAÇÃO DO MEMORIAL DA RESISTÊNCIA
}

Viviane Fecher

Brasília / DF 


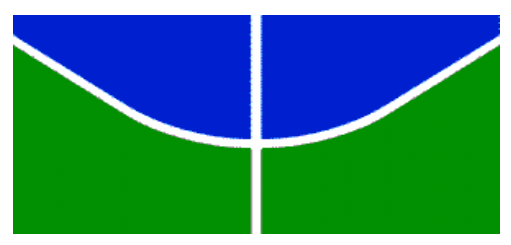

\title{
A HISTÓRIA É DE TODOS NÓS: \\ NARRATIVAS SOBRE A FORMAÇÃO DO MEMORIAL DA RESISTÊNCIA
}

\author{
Viviane Fecher
}

Dissertação apresentada ao Programa de Pós-Graduação em Direitos Humanos e Cidadania, da Universidade de Brasília. Área de Concentração: Direitos Humanos e Cidadania.

Linha de Pesquisa: História, Direitos Humanos, Políticas Públicas e Cidadania -, como requisito parcial para obtenção do título de Mestre em Direitos Humanos.

Orientadora: Prof $^{a} \cdot$ Dr$^{a}$. Cléria Botelho da Costa 
Ficha catalográfica elaborada automaticamente com os dados fornecidos pelo(a) autor(a)

FF291h

Fecher, Viviane

A história é de todos nós: narrativas sobre a formação do Memorial da Resistência. / Viviane Fecher; orientador Cléria Botelho da Costa. -Brasilia, 2015.

$211 \mathrm{p}$.

Dissertação (Mestrado - Mestrado em Direitos Humanos e Cidadania) -- Universidade de Brasília, 2015 .

1. Direitos humanos. 2. Cidadania. 3. História oral. 4. Memória. 5. Lugares de memória. I. Botelho da Costa, Cléria, orient. II. Título. 


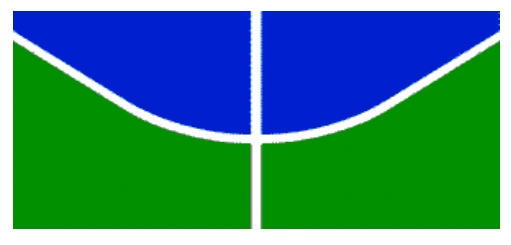

\begin{abstract}
Dissertação de autoria de Viviane Fecher, intitulada A HISTÓRIA É DE TODOS NÓS: NARRATIVAS SOBRE A FORMAÇÃO DO MEMORIAL DA RESISTÊNCIA, submetida ao Programa de Pós-Graduação em Direitos Humanos e Cidadania - Área de Concentração: Direitos Humanos e Cidadania. Na linha de Pesquisa: História, Direitos Humanos, Políticas Públicas e Cidadania.

Defendida e aprovada pela banca examinadora abaixo assinada:
\end{abstract}

Prof $^{a}$. Dr ${ }^{a}$. Cléria Botelho da Costa (Presidente)

Universidade de Brasília - PPGDH/UnB

Prof $^{\mathrm{a}}$. Dr ${ }^{\mathrm{a}}$. Eneá de Stutz e Almeida

Universidade de Brasília - FD/UnB

Profa. Dr $^{\mathrm{a}}$. Lucilia de Almeida Neves Delgado

Universidade de Brasília - PPGDH/UnB

Prof $^{\mathrm{a}}$. Dr ${ }^{\mathrm{a}}$. Maria Salete Kern Machado (suplente)

Universidade de Brasília - PPGDH/UnB

Brasília, 2015. 


\section{DEDICATÓRIA}

Ao meu pequeno Théo, por me lembrar todos os dias que ainda posso ser criança.

À minha avó Alzira, em memória, por cuidar de mim e me mostrar a beleza das flores da laranjeira, do sabor da ameixa no pé e do banho do sabiá.

A todas e todos que, diante das injustiças, se levantam e resistem. 


\section{AGRADECIMENTOS}

"A maior riqueza do homem é sua incompletude."

Manoel de Barros

Aos professores e professoras do Programa de Pós Graduação em Direitos Humanos e Cidadania da Universidade de Brasília, minha gratidão por ter encontrado na academia um espaço de acolhida dos meus ideais na crença em uma ciência construída a partir do afeto e do diálogo com o outro. Em especial, à professora Vanessa Maria de Castro, pela dedicação em meio a tantas intempéries na ccordenação do Programa, sem nunca se deixar desanimar e, acima de tudo, nos incentivando e torcendo por nós.

À minha querida orientadora, professora $\mathrm{Dr}^{\mathrm{a}}$. Cléria Botelho da Costa, gratidão imensa por ter abraçado minha pesquisa com tanto carinho e pela paciência, dedicação e perseverança constantes. Obrigada por confiar e acreditar em mim.

Às professoras doutoras Lucilia de Almeida Neves Delgado e Eneá de Stutz e Almeida, pelos ricos aportes trazidos na banca examinadora. Ao Prof. Dr. José Geraldo de Sousa Junior, pelas valiosas contribuições na banca de qualificação.

Aos amigos que me inspiram diariamente com seu brilhantismo na busca incessante pela memória, verdade e justiça, dos tempos de ontem e nas lutas de hoje: Paulo Abrão, Inês Virgínia Prado Soares, Marlon Alberto Weichert, Sueli Aparecida Bellato e Marcelo Torelly - obrigada pela honra dos trabalhos conjuntos, pela confiança e incentivos tão generosos. Aos conselheiros da Comissão de Anistia e procuradores da República, pelos exemplos e inspirações.

Aos narradores, que generosamente compartilharam comigo suas histórias de vida para que eu pudesse avançar nesta empreitada, e deram vida e ânimo à minha pesquisa - Rose Nogueira, Elza Lobo, Ivan Seixas e Maurice Politi.

A tantos outros nomes que poderiam igualmente emprestar suas vozes nesta tarefa de nos aproximar de nosso passado comum, mas que certamente o fizeram preenchendo meus pensamentos com seus exemplos de luta - lara, Gilney, Alípio, Martinelli, Paiva, Betto, Suzana, Victoria, Denise, Clara, Laura, Rita, muitos que nem 
sabem, mas que também estiveram comigo durante a construção dessas linhas.

À Katia Felipini, entusiasta de primeira hora do Memorial da Resistência e Ana Brito, pesquisadora apaixonada, pelas contribuições na minha pesquisa.

À Raquel Nogueira, Andreia Valentim, Tatiana Tannus Grama e Muller Borges, companheiros de jornada, nas dores e delícias da Comissão de Anistia e na vida. Marleide Ferreira Rocha e Luciana Ramos, meninas mulheres guerreiras, exemplos de vida, pelos incentivos que sempre me fortalecem. Aos colegas, amigos e amigas da Procuradoria Federal dos Direitos do Cidadão, pela torcida sempre cheia de entusiasmos e pelos exemplos de luta na vasta agenda dos direitos humanos.

À minha querida turma de mestrado, gratidão infinita. Aos que, enquanto colegas de jornada, partilharam comigo suas angústias, crescimentos e prazeres do compromisso que assumimos. $E$ aos amigos e amigas que esta vivência me presenteou, Diego Bernardo de Mendonça, Larissa da Silva Araújo, Fredson Oliveira Carneiro e Fábio Soares Alvino, pelos incentivos, afetos e risos, tão essenciais quanto nossos saberes compartilhados. À Priscila Paz Godoy, pelo carinho e aconchego, bálsamos em nosso mar revolto. À Julia Barros Schirmer, obrigada, de tudo e tanto, por me devolver o amor pelo meu trabalho. Em vocês renovo a certeza de que vale à pena crer e lutar por um mundo onde justiça e poesia caminhem de mãos dadas.

À minha família querida, pelo apoio e torcida que me permitiram avançar e concluir esse projeto. Aos Minghetti Joaquim, em especial, Regina e Joaquim, pelo suporte, carinho e respeito, acima de tudo. À família petropolitana que sempre vibrou por minhas vitórias e conquistas. Lica, Lara, Lua e Bel, minhas irmãs, por embarcarem nas minhas viagens, ouvirem meus lamentos e loucuras, e por nunca desistirem de mim.

Claudia, minha mãe amada, obrigada por ter me dado asas e por sempre acreditar nos meus sonhos, incondicionalmente.

E aos meus amores, Fábio e Théo, difícil, impossível agradecer tamanha abnegação, as renúncias dos momentos em família, a saudade nas minhas ausências, a paciência calada... Enfim, obrigada por terem permanecido aqui, meu porto seguro. 


\section{RESUMO}

Esta dissertação aborda alguns aspectos do processo de formação do Memorial da Resistência, lugar de memória na cidade de São Paulo, que reconfigura o prédio que abrigou o antigo DEOPS/SP durante a ditadura iniciada em 1964. A análise tem como ponto de partida as narrativas de ex-presos políticos que vivenciaram experiências naquela carceragem e que, quase quatro décadas mais tarde, a partir do ano de 2007, participaram do processo de sua transformação em memorial. A partir da perspectiva da participação social, busco compreender o papel da reconstituição de experiências de vida e dos lugares de memória na tarefa de enfrentar e superar episódios de sistemáticas violações de direitos humanos. Tratase de uma abordagem possível, dentre tantas, sobre histórias de vida e suas implicações no exercício da cidadania.

Palavras-chave: Memória social. História oral. Lugares de memória. Justiça de transição. Ditadura. Direitos Humanos. Cidadania. Memorial da Resistência. 


\section{ABSTRACT}

This dissertation discusses some aspects of the creation process of the Resistance Memorial, a place of memory in São Paulo, which reconfigures the building that once housed the old Deops/SP during the dictatorship that began in 1964. The analysis takes as its starting point the narratives of former political prisoners who lived experiences in those detention cells and, nearly four decades later, from 2007, participated in the process of its transformation into a memorial. From the perspective of social participation, seek to understand the role of the reconstitution of life experiences and places of memory in the task of facing and overcoming episodes of systematic human rights violations. This is one among many possible approaches to life stories and their implications in the exercise of citizenship.

Keywords: Social memory. Oral history. Memory places. Transitional justice. Dictatorship. Human Rights. Citizenship. Resistance Memorial. 


\section{LISTA DE ABREVIATURAS}

ALN - Ação Libertadora Nacional

AP - Ação Popular Marxista Leninista do Brasil

COC - Conselho de Orientação Cultural do Memorial da Resistência

CNPJ - Cadastro Nacional de Pessoa Jurídica

CONDEPE - Conselho Estadual de Defesa dos Direitos da Pessoa Humanado

Estado de São Paulo

DHESCA - Direitos Humanos Econômicos, Sociais, Culturais e Ambientais

DOI-CODI- Destacamento de Operações de Informações - Centro de Operações de

Defesa Interna

DEOPS - Departamento Estadual de Ordem Política e Social

DOPS - Departamento de Ordem Política e Social

MASP - Museu de Arte de São Paulo Assis Chateaubrian

MIS - Museu da Imagem e do Som

MPF - Ministério Público Federal

MRT - Movimento Revolucionário Tiradentes

MR- 26 - Movimento Revolucionário 26 de Março (MR-26)

OBan - Operação Bandeirantes

ONG - Organização Não Governamental

ONU - Organização das Nações Unidas

PSDB - Partido da Social Democracia Brasileira

PT - Partido dos Trabalhadores

PUC - Pontifícia Universidade Católica

P2 - Polícia Secreta

RG - Registro Geral

SESC - Serviço Social do Comércio

STF - Supremo Tribunal Federal

STM - Superior Tribunal Militar

TCC - Trabalho de Conclusão de Curso

UNESCO - Organização das Nações Unidas para a Educação, a Ciência e a Cultura USP - Universidade de São Paulo 
"Não quero lhe falar, meu grande amor, das coisas que aprendi nos discos. Quero lhe contar como eu vivi e tudo que aconteceu comigo. Viver é melhor que sonhar..."

Canção "Como nossos pais", de Belchior

"Recordar: do latim, re-cordare, voltar a passar pelo coração."

Eduardo Galeano 


\section{SUMÁRIO}

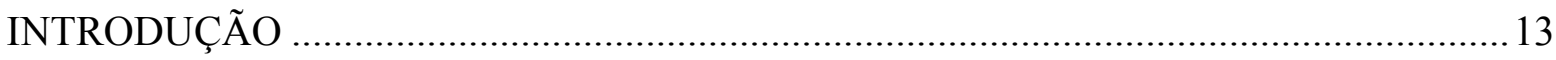

1 "OLHA, EXISTIU UMA RESISTÊNCIA BRASILEIRA": O SENTIDO E O PROCESSO DE FORMAÇÃO DO MEMORIAL DA RESISTÊNCIA .................................28

1.1 "Conhecer o passado para entender o presente e construir o futuro": a caminhada dos movimentos sociais na reconstituição da memória no Brasil

1.2 "Nós fincamos a bandeira da democracia": reivindicação e retomada DEOPS/SP para a construção do Memorial da Resistência 64

1.3 "A história é de todos nós": concepção e construção do Memorial da Resistência........74 2 “A HUMANIDADE VENCEU A BARBÁRIE": MEMORIAL DA RESISTÊNCIA COMO ESPAÇO VIVO DE EXERCÍCIO DA CIDADANIA

2.1 "Você não pode deixar o barco parado, tem que tocar": participação nas atividades do Memorial da Resistência

2.2 "E vocês, resistem a que?": no encontro de gerações, o compromisso com a juventude

2.3 "Aqui não é uma questão de violência": espaço expositivo marcado por homenagem e solidariedade 132

2.4 "Um grãozinho de areia": a percepção dos ex-presos políticos sobre os resultados do Memorial da Resistência

3 "NEM HERÓIS, NEM VÍTIMAS": A ESCOLHA PELOS CAMINHOS DE LUTA NA DITADURA E NA DEMOCRACIA 152

3.1 "Porque a ditadura é que está errada": quando resistir é preciso 152

3.2 "Um caminho de sempre pensar nos outros": entre perdas, incertezas e dores, venceu a solidariedade.

3.3 "Sou militante dos direitos humanos desde o dia que saí da cadeia": a vida depois, agora e adiante. 185

CONSIDERAÇÕES FINAIS 192

REFERÊNCIAS

ANEXO. 208 


\section{INTRODUÇÃO}

Algumas linhas de debates mais contemporâneos sobre a memória de experiências traumáticas alertam para uma "perigosa explosão" de seus usos que, em alguma medida, significariam o atestado de uma sociedade, que vive presa ao passado por falta de perspectiva futura. Em outras linhas se questionaria também o revanchismo que as memórias carregam e, por fim, até mesmo uma possível ética do esquecimento ${ }^{1}$.Qual, então, o sentido, de se revisitar um passado de sistemáticas violações de direitos humanos? Uma das provocações que impulsionam a presente pesquisa é justamente o papel das reconstituições de experiências de vida na superação das violações de direitos humanos e as consequentes reformas culturais, sociais e políticas que podem impelir. Eis o ponto de partida que sustenta o presente trabalho.

Partindo das narrativas que reconstituem as experiências de quatro ex-presos políticos presos nas carceragens do Departamento de Ordem Política e Social de São Paulo, o DEOPS/SP, durante a ditadura instaurada no Brasil no ano de 1964, e que, décadas mais tarde reuniram-se em torno da retomada e da ressignificação daquele ambiente, para transformá-lo no Memorial da Resistência, busquei compreender como o espaço atua na reconstituição daquelas violências e resistências no presente, de modo a contribuir com seu enfrentamento e superação.

A formação desse espaço, entre os anos de 2007 e 2009, veio no exato momento em que o Brasil aprofundava seus estudos no enfrentamento do legado da ditadura, por meio de ações de verdade, justiça e memória, enquanto conjunto de mecanismos propulsores das transições pós-conflito.

No Brasil, desde o próprio período de exceção, muitas ações vêm sendo realizadas dentro dessa perspectiva, embora em núcleos mais fechados e nem sempre com iniciativas e apoio do Estado. Com o fim da ditadura muitos grupos sociais mantiveram-se firmes na luta pela defesa dos direitos humanos, mantendo aberta a agenda de busca da verdade sobre as mortes e desaparições forçadas,

\footnotetext{
${ }^{1}$ Ver ensaio "Resistência à memória: usos e abusos do esquecimento público", de Andreas Huyssen In:Culturas do passado-presente: modernismos, artes visuais, políticas de memória.
} 
exigindo reparações e responsabilizações, realizando homenagens e evocando memórias.

As buscas dos desaparecidos da Guerrilha do Araguaia, guiada pelos familiares; as buscas de desaparecidos no Cemitério de Perus, em São Paulo, também por impulso das famílias; investigações civis e criminais por parte de Ministério Público Federal; reparações no âmbito da Comissão Especial sobre Mortos e Desaparecidos Políticos (CEMDP) ${ }^{2}$ e agora pela Comissão de Anistia do Ministério da Justiça $(\mathrm{CA} / \mathrm{MJ})^{3}$, são alguns exemplos de que a agenda nunca esteve fechada, embora não seja exagero afirmar, também, que se mantinha corrente em núcleos bem mais modestos que a grandiosidade da pauta exige, e exigiria mais tarde.

Foi no ano de 2003 que iniciei meus primeiros contatos com a agenda da justiça de transição no Brasil, embora naquela época ainda não se falasse nesses termos. Naquele ano passei a trabalhar como assessora na Comissão de Anistia, segundo órgão federal com atribuição de promover políticas de reparação aos perseguidos políticos.

Nasci no final da ditadura, no ano de 1978, na cidade serrana de Petrópolis, Estado do Rio de Janeiro, a 67 quilômetros da capital, e foi entre papéis amarelados, recortes de jornais velhos e narrativas em primeira pessoa, protocolados e arquivados nos escaninhos de Brasília, que eu soube, já na vida adulta, pela primeira vez, da existência de um centro clandestino de detenção na minha cidade. Na região central de Petrópolis, entre casas de classe média alta, região bem valorizada, estima-se que a Casa da Morte de Petrópolis, um verdadeiro centro de extermínio de lideranças da oposição à ditadura, recebeu pelo menos 19 militantes, dos quais somente uma sobreviveu. ${ }^{4}$

\footnotetext{
${ }^{2}$ Criada pela Lei $n^{\circ} 9.140$, de 04 de dezembro de 1995, que reconhece como mortas pessoas desaparecidas em razão de participação, ou acusação de participação, em atividades políticas, no período de 2 de setembro de 1961 a 15 de agosto de 1979, e dá outras providências.

3 Criada pela Lei $n^{\circ} 10.559$, de 28 de agosto de 2002, para regulamentar o artigo 8 do Ato das Disposições Constitucionais Transitórias, a Comissão tem o objetivo de analisar os pedidos de reparação de perseguidos políticos, a CA conta atualmente com o maior acervo de depoimentos de vítimas da ditadura, tanto em acervo documental, nos seus mais de 70 mil requerimentos protocolados, quanto acervo digital composto por áudios, vídeos, fotografias, cartazes, dentre outros materiais da época.

4 "Relatório Preliminar de Pesquisa sobre a Casa da Morte de Petrópolis", assinado e publicado pela Comissão Nacional da Verdade em março de 2014. Disponível em:
} 
A força da história daquele lugar contrapôs-se, em minha percepção, ao vazio e ao silêncio de sua existência para aquela comunidade. Nenhuma palavra sequer, nenhuma menção, nenhuma placa indicativa, nenhuma conversa sobre o caso. Essa e outras histórias sobre o que foram os tempos de governo de exceção e suas heranças saltavam daqueles papéis, assim como dos rostos e vozes nas sessões de apreciação de requerimentos de anistia realizadas no Palácio da Justiça em Brasília, sede da Comissão. A partir dali, vivenciaria pelos próximos anos um contato cada vez mais estreito com as narrativas de vítimas e familiares de vítimas da ditadura. $\mathrm{E}$, naquele contato, iniciava um trabalho que me traria muito mais que experiência profissional. Para além de aprofundar meus conhecimentos sobre parte importante da história do Brasil e atuar no processo de reparação a perseguidos políticos, fui estreitando meus laços com as testemunhas daquele período, suas histórias de vida e a própria história do país.

Com o passar do tempo, as vozes daqueles tantos cidadãos e cidadãs foram ganhando um espaço nunca antes visto no Brasil, e formando o maior acervo sobre a ditadura construído na primeira pessoa, em que os próprios perseguidos políticos, homens e mulheres, contam suas experiências de resistência, sequestro, prisão, tortura, perda de companheiros, exílio, clandestinidade, perda do emprego, exonerações, humilhações, censura e superações.

O conjunto de recordações de períodos de sistemáticas violações de direitos humanos vem sendo considerado um valioso mecanismo para a superação de suas heranças, na reforma de aparatos do Estado e, também, nos esclarecimentos das circunstâncias em que se deram as violações. Além de servirem a processos administrativos e judiciais e como fonte de pesquisas acadêmicas e jornalísticas, o conjunto dessas recordações sociais, quando avivadas, pode colaborar sobremaneira para a construção de uma nova cultura política de proteção e promoção dos direitos humanos e da dignidade humana. ${ }^{5}$

\footnotetext{
$<$ http://cnv.gov.br/images/pdf/petropolis/Versao_final_-_Casa_da_Morte_relatorio_preliminar_revisado.pdf.>Acesso em: 10 jul. 2015.

${ }^{5}$ TORELLY, Marcelo D. Justiça Transicional, Memória Social e Senso Comum Democrático: notas conceituais e contextualização do caso brasileiro. In: Repressão e Memória Política no Contexto Íbero-Brasileiro: Estudos sobre Brasil, Guatemala, Moçambique, Peru e Portugal. Brasília: Ministério da Justiça, Comissão de Anistia; Portugal: Universidade de Coimbra, Centro de Estudos Sociais, 2010.p. 104-123.
} 
Segundo estudos que estão sendo realizados nas práticas de diversos países, os quais passaram por períodos de sistemáticas violações de direitos humanos e que vêm implementando mecanismos para vencer os seus legados, a memória social é capaz de atuar como mediadora de gerações, reforçando a capacidade de transmissão de valores, conteúdos e atitudes, enquanto constituintes da nova cultura social. ${ }^{6}$

Especialmente no Brasil, a memória coletiva ou social da ditadura passou a ganhar ênfase nos últimos anos como política pública, momento em que passou a adotar explicitamente as recomendações da justiça de transição - processo internacionalmente reconhecido e utilizado em países que sofreram períodos de massivas e sistemáticas violações de direitos humanos. A memória coletiva estaria, então, entre os eixos primordiais desse processo de transição democrática, capaz de romper com a cultura das violações, fazendo uso de diversos mecanismos, como monumentos, datas comemorativas, nomes de logradouros e lugares de memória.

No ano de 2010, desenvolvi, em sede de especialização latu sensu, meu primeiro trabalho acadêmico na temática da memória coletiva da ditadura, com foco nas atuações oficiais e não oficiais de preservação e promoção de memórias aplicadas no caso brasileiro. Ali conheci mais profundamente parte dos trabalhos realizados por órgãos de Estado e, também, pela sociedade civil e por grupos de vítimas e familiares de vítimas nesta seara ${ }^{7}$. Ainda durante a especialização, a utilização dos chamados lugares de memória, despertavam meu interesse, enquanto possíveis mecanismos colaboradores do enfrentamento e superação de episódios de violação de direitos humanos.

Convertidos em "suportes ou propagadores de memória coletiva", esses espaços se anunciam como veículos de reflexão sobre os acontecimentos do passado de modo a transmiti-los às gerações presentes e futuras, além de

\footnotetext{
${ }^{6} \mathrm{BOSI}, 2003$,p. 15.

${ }^{7}$ Naquele ano, passei a trabalhar na Procuradoria Federal dos Direitos do Cidadão, órgão do Ministério Público Federal, prestando assessoramento a procuradores e procuradoras da República atuantes no tema da Justiça de Transição, dentre eles, ações de memória.

${ }^{8}$ Principios Fundamentales sobre Sitios de Memoria, documento elaborado pelo Instituto de Políticas Públicas em Direitos Humanos do Mercosul (IPPDH), adotado por ocasião da XXII Reunião de Altas Autoridades em Direitos Humanos e Chancelarias do Mercosul e Estados Associados (RAADH), realizada de 3 a 6 de setembro de 2012, na cidade de porto Alegre, Brasil. Disponível emhttp://www.ippdh.mercosur.int/principios-fundamentales-para-las-politicas-publicas-en-materia-desitios-de-memorial. Acesso em:
} 
promoverem ações que vão desde o reconhecimento das violações até homenagem às lutas.

Incorporados a uma corrente mais contemporânea da sociomuseologia, voltada à interação desses espaços com a comunidade local e em resposta a seus anseios, esses ambientes se mostravam crescentes no Brasil. Surgiam, assim, para mim, ainda mais perguntas referentes ao processo de construção da memória social da ditadura, sua materialização e sua função social.

Dessa forma, questiono de que modo a reconstituição de experiências de vida contribui para o enfrentamento das sistemáticas violações de direitos humanos. Como os lugares de memória, à medida que se propõem a materializar as memórias sociais, auxiliam nesse processo? Como se dá a participação social nessa construção?

Partindo dos questionamentos acima, persegui a hipótese de que este processo, mais que construir memórias, estimula o diálogo e a reflexão necessárias à ampliação do exercício da cidadania.

A partir destas questões, ao decidir dar continuidade à minha pesquisa, agora em sede de mestrado, não tive dúvidas, desde o início, sobre o macro tema a ser pesquisado: a reconstituição de recordações como forma de enfrentamento e superação de sistemáticas violações de direitos humanos, ou melhor, investigar como e de que maneira a memória social intervém ou contribui para esse processo.

Pela característica multidisciplinar da própria temática da justiça de transição, e pelo desejo de desenvolver um trabalho que envolvesse participação social, construção da memória coletiva e lugares de memória, o projeto apontava para a necessidade de me apoiar, ao menos de início, sobre referenciais da história, sociologia, psicologia social e do direito.

Assim, cheguei ao Programa de Pós-Graduação em Direitos Humanos e Cidadania - PPGDH da Universidade de Brasília. Entre suas linhas de pesquisa, encontra-se História, direitos humanos, políticas públicas e cidadania, que tem como proposta o estudo de políticas públicas de direitos humanos como garantia da cidadania por meio da investigação dos processos históricos.

Já sob orientação da professora do Programa Cléria Botelho da Costa, vinculada ao Departamento de História da Universidade de Brasília, iniciei a leitura 
dos recortes necessários, optando por uma pesquisa em profundidade. O projeto inicialmente apresentado à banca de seleção do PPGDH, no ano de 2013, tinha a pretensão de analisar o processo de participação social na construção da memória da ditadura por meio do estudo de diversos lugares de memória. O universo da proposta inicial, no entanto, era extenso demais para os objetivos de uma pesquisa no tempo possível do mestrado. Assim optei pela delimitação do objeto a um único memorial.

Parti em busca de um lugar de memória sobre as experiências vivenciadas durante a ditadura iniciada em 1964, que deveria contar com alguns predicados: estivesse em pleno funcionamento, já tendo passado pelas fases de concepção, projeto, construção, inauguração e mantivesse atividades correntes; e tivesse contado com a participação da sociedade na sua formação. Assim, cheguei ao Memorial da Resistência, inaugurado em 2009, na cidade de São Paulo, espaço construído no próprio prédio que serviu ao Departamento Estadual de Ordem Política e Social de São Paulo - DEOPS/SP, entre os anos de 1940 a 1983, notabilizado como uma das polícias políticas mais truculentas e sangrentas da repressão.

Delimitado o objeto, optei por utilizar as narrativas dos resistentes políticos como fonte principal da pesquisa. O interesse maior era reconstituir o processo de formação daquele espaço a partir das recordações do grupo que lá esteve preso e que anos mais tarde trabalhou por sua retomada e ressignificação. Acabei por utilizar, da mesma forma, textos produzidos pelos agentes públicos e profissionais do Memorial, mas enquanto fontes complementares. Outras fontes documentais também foram consultadas, como documentos do Fórum Permanente de Ex-Presos e Perseguidos Políticos de São Paulo e da entidade Núcleo Memória. Somaram-se à pesquisa vídeos institucionais sobre o DEOPS e o Memorial, e outras entrevistas concedidas pelos narradores, disponíveis na rede mundial de computadores.

A escolha da história oral como nascente para a reconstituição do processo de formação do Memorial da Resistência é também a opção pelo desejo de compreender as dimensões subjetivas do projeto e do próprio trabalho, forjadas nos sentimentos, emoções, valores, consciência, motivações e percepções daqueles que vivenciaram aquelas experiências. 
É importante destacar que, na escolha de trabalhar a oralidade, tão pouco busquei a veracidade dos fatos. Não coloquei em momento algum, os narradores no banco dos réus. Não se trata de inquirir qual versão é a mais verdadeira, pois o narrador, "como todos nós, conta a sua verdade" (BOSI, 2003, p.65).

Ao contrário, a intenção maior foi dar espaço para que as diversas versões viessem à tona, na composição maior da grande colcha de retalhos que se configura a memória social. Neste conjunto de recordações, surgem imagens que nos permitem compreender o que foi o processo de formação do Memorial da Resistência.

Tendo, então, como objetivo geral a reconstituição da memória coletiva do processo de formação e transformação do espaço, a partir das múltiplas visões dos que vivenciaram as experiências do DEOPS, demarquei alguns objetivos específicos: (1) conhecer e analisar a história de idealização, nascimento, formação e transformação do Memorial da Resistência, desde os episódios que o antecederam, por meio da reconstituição do histórico de funcionamento do DEOPS/SP e os caminhos que levaram até Memorial; (2) apreender as dimensões individuais e subjetivas dos sujeitos envolvidos no processo; e (3) analisar essas apreensões em diálogo com as teorias da psicologia social, história, sociologia e direito.

A opção pelas narrativas exigia, então, a identificação e delimitação dos colaboradores. O sítio virtual do Memorial da Resistência indicava a parceria com a entidade Núcleo de Preservação da Memória Histórica, ou Núcleo Memória, formado no âmbito do Fórum Permanente de Ex- presos Políticos de São Paulo. Meu contato inicial com o Núcleo veio por meio de lara Xavier, militante política desde a ditadura, fundadora e presidente do Comitê Memória, Verdade e Justiça do Distrito Federal. lara, com quem me relaciono desde meus trabalhos desenvolvidos junto à Comissão de Anistia do Ministério da Justiça, me colocou em contato com Maurice Politi, expreso político do DEOPS/SP e um dos fundadores do Núcleo Memória. Foi ele quem me colocou em contato com os demais ex-presos que atuaram na formação do Memorial.

Ao todo, foram oito os ex-presos políticos do DEOPS/SP que participaram do 
processo de formação do Memorial da Resistência. ${ }^{9}$ Considerando a opção pela análise das narrativas em profundidade, não se tratando de um trabalho de amostragem, mas de registro de vozes e reconstituição de lembranças, cheguei ao recorte de aproximadamente cinquenta por cento de participantes do processo de criação do Memorial, e deliberei por quatro narradores.

Com esse número, optei por garantir a equidade de gênero, embora essa questão não faça parte dos critérios de análise dos conteúdos das entrevistas, decidindo pela escuta de dois homens e duas mulheres. As únicas duas mulheres identificadas no processo foram Rose Nogueira e Elza Lobo. Entre os homens, escolhi dois fundadores do Núcleo Memória, entidade que se formaria mais tarde para atuar na promoção da memória em diversas frentes na cidade de São Paulo: Maurice Politi e Ivan Seixas. Os quatro narradores foram resistentes políticos que se insurgiram contra a ditadura, ainda bem jovens, e que na condição de presos políticos, passaram, dentre tantos outros espaços no Estado de São Paulo, também pelas carceragens do DEOPS/SP. ${ }^{10}$

Realizados os convites para que colaborassem com a pesquisa, uma primeira percepção me chamou bastante atenção. Sentia nas suas falas, mesmo por e-mail e telefone, um sentimento de gratidão, que, além de me comover, também me surpreendeu.

A temática das violações de direitos humanos praticadas durante a ditadura instaurada no Brasil tem sido bastante explorada pela pesquisa acadêmica nos últimos anos e, também, despertado o interesse dos meios de comunicação. Além disso, os quatro convidados são bem atuantes na militância pelos direitos humanos e têm suas histórias de vida durante a ditadura já bastante reverberadas em

\footnotetext{
${ }^{9}$ A participação na construção do Memorialé atribuída ao grupo de narradores e em registros do próprio Memorial a mais quatro ex-presos: Raphael Martinelli, Alípio Freire, Frei Beto e José Paiva, não ouvidos na presente pesquisa. Não raro, em suas falas, os quatro narradores fazem menção à participação desses quatro e me incitam a também entrevistá-los. Neste momento, parecia haver uma preocupação voltada à consideração com a participação de todos os envolvidos, de modo que ninguém ficasse de fora da pesquisa.

${ }^{10}$ Outros nomes, constantemente citados nas narrativas, e também em documentos sobre a criação do Memorial da Resistência, certamente dariam excelentes fontes de pesquisa. No entanto, como dito, o tempo e tipo de análise por profundidade, me impediram de buscá-los. Sou, no entanto, muito grata às indicações e disponibilidade, inclusive, dos que não cheguei a ouvir como colaboradores: Alípio Freire e Raphael Martinelli.
} 
diversas publicações sobre o tema. ${ }^{11}$ Por que, afinal, a tamanha alegria com meu convite?

Todos, sem exceção, além da disponibilidade imediata em participar da pesquisa, expressavam imensa felicidade pela minha escolha em pesquisar suas atividades no Memorial da Resistência. Com a continuidade dos contatos e, posteriormente, durante as entrevistas, comecei a entender o diferencial de meu convite que despertava no grupo essa grande emoção. Na percepção do próprio grupo, em geral, os perseguidos políticos brasileiros são procurados para falar das violações sofridas e testemunhadas e das dores vivenciadas àquela época. Meu foco de pesquisa, porém, era justamente outro: suas histórias de vida já no período de democracia, mais precisamente seu papel na formação da memória social e do Memorial da Resistência. Neste ponto, ouso anunciar que os narradores já previam nas entrevistas a possibilidade de falar não só sobre a resistência política à ditadura, mas também e, sobretudo, sobre a militância política e a luta por direitos nos dias atuais. Essas são referências que surgem constantemente nas quatro narrativas.

Antes de apontar a metodologia utilizada e a formatação dos capítulos, é necessário esclarecer a escolha terminológica como me refiro ao grupo de colaboradores, aqui chamados também de narradores ou memorialistas. Os quatro rejeitam qualquer termo que os vitimize e se autodenominam "resistentes". Poderia assim ter optado por essa nomenclatura.

No entanto, a condição que os une como narradores neste trabalho é sua participação no processo de formação do Memorial da Resistência na qualidade de "testemunhas" do DEOPS/SP, uma vez que foram mais que espectadores daquelas carceragens, sendo atores, partícipes e protagonistas das experiências ali vivenciadas na condição de presos políticos. Para tanto, afastei o termo "testemunha" e optei por me referir a eles como "ex-presos políticos", sem nenhuma conotação pejorativa de enxergá-los como vítimas.

Delimitado o grupo de narradores, escolhi como metodologia a realização de entrevistas semiestruturadas, guiadas por questões-chave e gravadas em áudio.

\footnotetext{
${ }^{11}$ Como exemplo, Maurice Politi conta sua experiência no livro-diário "Resistência atrásdas grades"; Rose Nogueira e Elza Lobo estavam, à época da minha pesquisa, concedendo entrevistas para o documentário "Torre das Donzelas"; e a história de Ivan Seixas é encontrada em diversos depoimentos e testemunhos, além de relatórios oficiais do Estado brasileiro.
} 
Esta modalidade permite que o narrador traga à tona suas lembranças com mais liberdade, desenhando sua própria cronologia, que nem sempre condiz com o tempo do calendário e mergulhando em temas e subtemas que, muitas vezes, não estavam no script do pesquisador, mas que se mostram relevantes para quem recorda. Em muitos momentos, me deixei guiar pelo próprio entrevistado, fato que, mais adiante, acabou por guiar as divisões dos capítulos, conforme as temporalidades e tema surgidos das narrativas. Nesse processo em que se dá o encontro entre ouvinte e narrador, quem fala quer ser ouvido e quem ouve deve saber receber. Ao ouvi-los, fui sendo instigada a colocar-me em diversas daquelas posições de modo a permitir a criação do vínculo necessário entre pesquisador e entrevistado, capaz de permitir um contato dialógico que me daria acesso às suas vivências. Para além das entrevistas pessoais, com o posterior estudo das narrativas, foi necessário solicitar algumas complementações por meio de breve questionário escrito, respondido via correspondência eletrônica.

Tive um encontro com cada um dos narradores, na cidade de São Paulo, em locais escolhidos por cada um deles. Inicialmente, apresentei-lhes o tema, objeto e objetivo da pesquisa, tendo como foco sua experiência no processo de formação do Memorial, e me limitei a solicitar que trouxessem sua apresentação pessoal, contextualização de sua história de vida durante a ditadura e sua visão sobre o processo de formação do Memorial. Ao longo das entrevistas, no entanto, foi necessário, de um modo geral, trazer algumas questões-chaves mais específicas à medida que elas não surgiam espontaneamente, como, por exemplo: como se sentiram ao voltar ao espaço onde estiveram presos; sua relação com os demais expresos políticos; como se viram nesse processo, etc.

Por outro lado, muitos significados surgiram de modo inesperado nas falas: a força da palavra resistência, também nos dias de hoje; o forte compromisso com a juventude atual; as lembranças dos tempos de solidariedade no cárcere; e o sentido de que a "luta" continua são alguns exemplos que pautaram as escolhas da formatação dos capítulos, exigindo, ainda, a reformulação de alguns referenciais teóricos. Na formatação dos capítulos e seus tópicos, as falas diretas deram origem aos títulos, razão pela qual aparecem entre aspas.

A tarefa de registrar vozes trouxe também a compreensão do que Bosi (1987, 
p.3) chama de "cabedal infinito da memória". Antes ou após o término das entrevistas, foi comum ouvir dos narradores muitas impressões que não ficaram registradas na gravação e todas com tamanha riqueza, as quais não foram desconsideradas no presente texto.

Em um desses momentos, por exemplo, presenciei um telefonema. Enquanto almoçávamos no restaurante do Memorial, o narrador Ivan Seixas atendeu a uma ligação. Era um motorista que o atendera naquela semana e que ligava para agradecer pela conversa que tiveram durante a corrida. Casualmente, enquanto corriam pela cidade, Ivan Seixas Ihe contou sobre a "tal" ditadura, a repressão política e as lutas de resistência, histórias até então desconhecidas pelo rapaz. Ao desligar o telefone, emocionado, com os olhos cheios d’água, Ivan Seixas foi categórico: “Isso paga tudo!". A cena já anunciava o que seria, horas depois, nossa entrevista.

Realizadas nos meses de novembro de 2014 e em janeiro de 2015, três entrevistas ocorreram no próprio Memorial, por escolha dos narradores - Elza Lobo, Ivan Seixas e Maurice Politi. Os locais escolhidos parecem refletir já alguns significados igualmente considerados nos momentos de releituras das narrativas e diálogo com as bases teóricas. Por exemplo, notei que os narradores Ivan Seixas e Maurice Politi transitavam de modo bem confortável pelo espaço, sendo bastante conhecidos dos funcionários, o que, posteriormente, identifiquei como consequência da parceria do Memorial com o Núcleo Memória, entidade criada por eles e de suas intensas participações nas atividades realizadas no Memorial. Já a narradora Elza Lobo, embora também participe das atividades do Núcleo, movimentava-se pelo Memorial de modo mais tímido. Rose Nogueira me apresentou parte de sua intimidade, compartilhando comigo a rotina de uma tarde na sua casa, entre cafés, pássaros e flores do jardim, animais de estimação, fotografias do filho e outras tantas lembranças de vida espalhadas pela casa.

Posteriormente às entrevistas, optei por realizar eu mesma as respectivas transcrições, para elaboração do documento escrito não publicado na sua totalidade na qualidade anexo, como se poderia fazer. Escolhi trazer partes das narrativas no decorrer do texto em diálogo com os referenciais teóricos. No trabalho de transcrição, foram mantidas as falas somente com algumas correções de estilo, para 
tornar o texto mais inteligível na leitura. Assim, foram substituídas algumas expressões que funcionam melhor na linguagem oral cuja subtração não prejudica a conotação ou compreensão dos significados das falas como, por exemplo, "né”, "aí", "é", "tá", "certo", "pra" e outras semelhantes.

Os núcleos temáticos foram sistematizados a partir das próprias falas, conforme os assuntos surgiam e se repetiam, sendo identificados com as categorias constituintes da hipótese da presente pesquisa, segundo a qual, a participação social na construção do Memorial da Resistência estimula o exercício da cidadania, quais sejam: percepção do sentido de cidadania; dever de participação social nas escolhas referentes à vida pública; sentido dessa participação; participação voluntária; sentido de transformação social; percepção de expansão e inclusão de direitos; percepção do sentido de memória coletiva; sentido e valor do espaço de memória; reflexos das vivências do passado com o tempo atual, dentre outros.

A partir deste momento, iniciei um diálogo entre as narrativas e os referenciais teóricos. Para buscar compreender as narrativas, me vali dos autores centrados na memória social Maurice Halbwachs e Michael Pollak, ambos da Sociologia. Com Ecléa Bosi, da Psicologia Social, analisei os aspectos do encontro de gerações por meio das narrativas.

As funções e os usos da memória no enfrentamento de sistemáticas violações de direitos humanos foram abordadas a partir dos juristas, especialistas em justiça de transição, Ruti Teitel e Paul Van Zyl, além dos estudos contemporâneos sobre as relações entre memória e direitos humanos a partir do historiador Andreas Huyssen.

$\mathrm{Na}$ análise do papel dos lugares de memória e, mais especificamente, do Memorial da Resistência, fiz uso das teorias do historiador Pierre Nora e do arqueólogo, historiador e museológo Hugues de Varine-Bohan, especialista em sociomuseologia. Por fim, a participação social na formação do Memorial foi analisada a partir da teoria da nova cidadania desenvolvida pela cientista política Evelina Dagnino.

Para guiar o trabalho de escuta, registro e análise das narrativas, utilizei como referenciais teóricos Eugênia Meyer e Tânia Gandon. A primeira me trouxe suportes para analisar as entrevistas considerando a perspectiva imaginativa e inventiva, não como trabalho de busca de uma única verdade, mas, ao contrário, uma busca capaz 
de "atender, escutar e observar as diferentes verdades." Sem deixar de ser "rigorosa e científica", a autora me incentivou a uma escuta mais disponível e desprendida. ${ }^{12} \mathrm{Na}$ medida em que são trabalhados testemunhos diretos, após a conclusão de seus registros, segui seu indicativo de desconstruir as narrativas, buscando compreendê-las na sua totalidade ${ }^{13}$. Com Gandon, me vi estimulada a trabalhar a percepção das disposições subjetivas e simbólicas dos discursos da memória, como gestual e entonação de voz, enquanto elementos essenciais da comunicação oral, bem como a identificação de eixos temáticos e marcos temporais nas falas dos entrevistados ${ }^{14}$.

As narrativas dividem-se em três tempos bem marcantes, nem sempre apresentados em ordem cronológica. Primeiramente, as recordações de um passado bem recente pontuado pelo período em que estiveram envolvidos com o processo de formação do Memorial da Resistência, entre os anos de 2007, até sua inauguração em 2009. Posteriormente, foram trabalhadas as narrativas sobre suas experiências ainda mais recentes nas atividades desenvolvidas por meio do Memorial em diálogo com a comunidade, desde sua inauguração. Por fim, o terceiro tempo abordado trata das reconstituições de suas experiências de vida desde a ditadura até chegar ao reencontro do grupo para a retomada e formação do Memorial.

A partir da divisão temporal, carregada de três sentidos bem marcantes, quais sejam, resistência política, compromisso com a juventude e solidariedade, respectivamente, foram ordenados os três capítulos que dão forma aos resultados da pesquisa.

Tanto o título, quanto os nomes dos capítulos e subtítulos são constituídos de frases ditas pelos próprios narradores. O título "A história é de todos nós", denota, desde o início, o caráter coletivo do desejo e intencionalidade do grupo na escolha pela participação no projeto do Memorial. Suas experiências pessoais, agora reconstituídas, são as experiências de um grupo, quiçá de uma época, tesouro garimpado na oralidade.

\footnotetext{
${ }^{12}$ MEYER, Eugênia. O fim da memória. Revista Estudos Históricos, Rio de Janeiro, v. 22, n. 43, jan.-jun., 2009, p. 31-44.

${ }^{13}$ MEYER. 2009, op. cit. p. 40.

${ }^{14}$ GANDON, 2001, p. 139-155.
} 
Sob o título "Olha, existiu uma resistência brasileira": o sentido e o processo de formação do Memorial da Resistência, o primeiro capítulo traz a reconstituição das lembranças no processo que deu origem ao Memorial da Resistência. Nele, é trabalhado o caminho trilhado pelos movimentos sociais na luta pelo nãoesquecimento das violações de direitos humanos praticadas durante a ditadura, até chegar ao momento de reencontro do grupo de narradores em torno da reivindicação do prédio do DEOPS e as atividades que se seguiram até a inauguração do espaço. O sentido da resistência política é trabalhado com maior profundidade, desde a resistência à ditadura até a resistência política necessária também no Estado Democrático de Direito. É nesse momento que surgem as categorias de justiça de transição, memória coletiva e espaço de memória.

No capítulo segundo, intitulado "A humanidade venceu a barbárie": Memorial da Resistência como espaço vivo de exercício da cidadania, são abordadas as percepções do grupo de narradores quanto ao trabalho realizado no Memorial da Resistência junto à comunidade, após sua inauguração. Aqui é abordado o sentido de compromisso com a juventude e com o direito à memória, apontados com ênfase pelos narradores enquanto fim último de suas ações políticas, em diálogo com os princípios da sociomuseologia.

Por fim, o terceiro capítulo "Nem heróis, nem vítimas": a escolha pelos caminhos de luta na ditadura e na democracia, reconstitui as lembranças do grupo de narradores sobre os tempos de militância e resistência política em face da ditadura, as escolhas políticas na juventude, a vida no cárcere e a eterna luta em defesa dos direitos humanos e da dignidade humana, trazendo como sentido basilar, a solidariedade das celas às ruas e também nos dias de hoje.

Certamente, a jornada de trabalhar histórias de vida me preencheu com ainda mais questionamentos a respeito da matéria abordada. O trabalho não se encerra aqui. Sem nenhuma pretensão de ter esgotado o tema ou, ainda, de oferecer uma única leitura possível das experiências que me foram generosamente compartilhadas, parafraseando Hugues De Varine-Bohan, eis aqui o resultado do que ouvi e do que penso ter entendido. 
"OLHA, EXISTIU UMA RESISTÊNCIA BRASILEIRA"

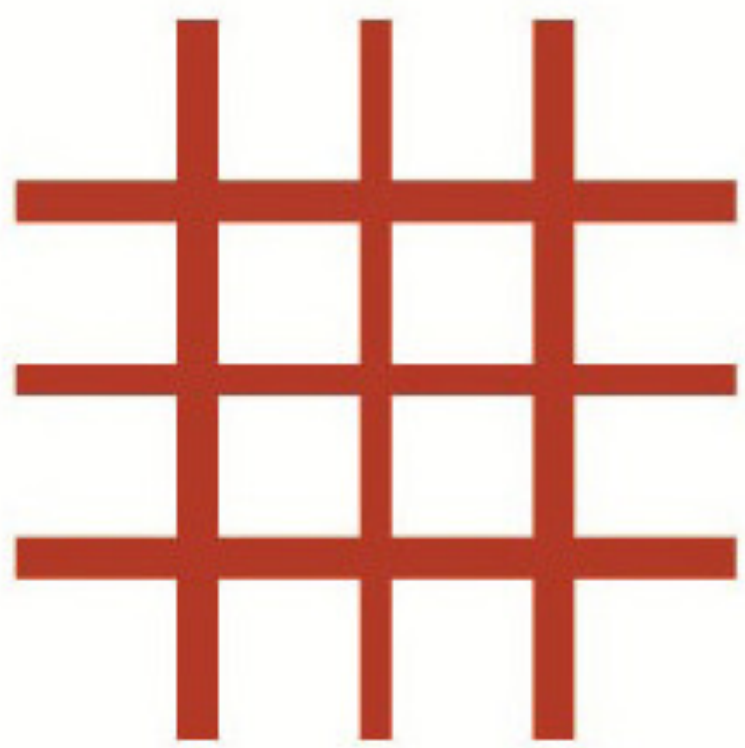

llustração 1. Logotipo do Memorial da Resistência, representando as grades nas janelas das celas. 


\section{1 "OLHA, EXISTIU UMA RESISTÊNCIA BRASILEIRA" 15: O SENTIDO E O PROCESSO DE FORMAÇÃO DO MEMORIAL DA RESISTÊNCIA}

O primeiro capítulo traz como núcleo de análise o processo de formação do Memorial da Resistência, sob a perspectiva do grupo de narradores, ex-presos políticos do DEOPS/SP, em diálogo com os preceitos da nova cidadania, enquanto reivindicação social à participação na construção de expansão de direitos e do próprio sistema político brasileiro. Para chegar neste momento de suas recordações, passamos pela trajetória das reivindicações sociais em face do enfrentamento das violações de direitos humanos praticadas durante a ditadura, desde aqueles tempos, até a organização de um grupo de ex-presos em torno do Memorial. Posteriormente, analiso o fortalecimento da pauta da justiça de transição no Brasil e, mais precisamente, da memória, enquanto mecanismo de superação das violações. Finalmente, chego ao reencontro do grupo de ex-presos políticos, narradores dessa história, e de sua decisão de fortalecer a agenda da memória social.

1.1 "CONHECER O PASSADO PARA ENTENDER O PRESENTE E CONSTRUIR O FUTURO" 16 : A CAMINHADA DOS MOVIMENTOS SOCIAIS NA RECONSTITUIÇÃO DA MEMÓRIA NO BRASIL

No Brasil, passados quase trinta anos desde o fim da última ditadura, iniciada como golpe de 1964, e que perdurou até meados da década de 1980, ainda é possível identificar práticas sucessivas de violações aos direitos humanos por agentes de Estado e que, em muitos momentos, parecem seguir sendo socialmente reproduzidas e toleradas ${ }^{17}$.

\footnotetext{
${ }^{15}$ Fala da narradora Rose Nogueira em entrevista concedida em 07 nov. 2014.

${ }^{16}$ Fala do narrador Ivan Seixas em entrevista concedida em 08nov.2014.

${ }^{17}$ Pesquisa realizada em 2010 pelo Núcleo de Estudos da Violência da Universidade de São Paulo (NEV-USP) concluiu que quase metade dos brasileiros concorda que os tribunais aceitem provas
} 
O período foi marcado por violações e restrições de direitos nos mais variados campos:

O habeas corpus foi suspenso para crimes políticos, deixando os cidadãos indefesos nas mãos dos agentes de segurança. A privacidade do lar e o segredo da correspondência eram violados impunemente. Prisões eram feitas sem mandado judicial, os presos eram mantidos isolados e incomunicáveis, sem direito a defesa. Pior ainda: eram submetidos a torturas sistemáticas por métodos bárbaros que não raro levaram à morte da vítima. A liberdade de pensamento era cerceada pela censura prévia à mídia e às manifestações artísticas e, nas universidades, pela aposentadoria e cassação de professores e pela proibição de atividades políticas estudantis.

O poder judiciário, em tese o garantidor dos direitos civis, foi repetidamente humilhado. Ministros do Supremo Tribunal foram aposentados e tiveram seus direitos políticos cassados. Outros não fizeram honra à instituição, colaborando com o arbitrário. O número de ministros foi aumentado para dar maioria aos partidários do governo. Além disso, a legislação de exceção, como o Al-5, suspendeu a revisão judicial dos atos de governo, impedindo os recursos aos tribunais. ${ }^{18}$

A repetição quase obsessiva das múltiplas violências de Estado ocorre, em grande parte, pela impossibilidade social de reconhecê-las como tal ${ }^{19}$, sendo atribuída sua prática também à permanência de uma forte cultura de silêncio e obscurantismo, responsável por inviabilizar a real e total compreensão dos acontecimentos por parte da sociedade, em especial, por aquelas gerações que não vivenciaram as experiências do passado. A questão aparece como uma das conclusões dos trabalhos de investigação realizados pela Comissão Nacional da Verdade, em seu Relatório Final, publicado em dezembro de 2014:

obtidas através de tortura. Ainda, quase um terço dos entrevistados defende o uso pela polícia de algum tipo de ação que possa ser tipificada como tortura. Disponível em: <http://www.nevusp.org/downloads/down264.pdf> (p. 293-389). Acesso em: 24ago. 2012. Outro estudo, realizado em 2012 pelo Instituto de Pesquisa Econômica Aplicada (IPEA), apurou que a maioria dos entrevistados desconhecia a Lei da Anistia de 1979. Entre aqueles que conheciam a Lei, no entanto, mais da metade aprovavam a investigação das práticas de violações de direitos humanos e algum tipo de punição para os responsáveis, demonstrando que o conhecimento sobre os acontecimentos gerou indignação social e intolerância para com as práticas violentas do Estado. Disponível

em: <http://www.ipea.gov.br/portal/images/stories/PDFs/SIPS/120229_sips_defesanacional_3.pdf>. Acesso em: 24 jul. 2015.

${ }^{18}$ CARVALHO, 2013, p.193-194.

${ }^{19}$ GENRO, Tarso; ABRÃO, Paulo. Memória Histórica, Justiça de Transição e Democracia sem Fim. In: Repressão e Memória Política no Contexto Íbero-Brasileiro: Estudos sobre Brasil, Guatemala, Moçambique, Peru e Portugal. Brasília: Ministério da Justiça, Comissão de Anistia; Portugal: Universidade de Coimbra, Centro de Estudos Sociais, 2010. p. 16-24. 


\begin{abstract}
A CNV, ao examinar o cenário de graves violações de direitos humanos correspondente ao período por ela investigado, pôde constatar que ele persiste nos dias atuais. Embora não ocorra mais em um contexto de repressão política - como ocorreu na ditadura militar -, a prática de detenções ilegais e arbitrárias, tortura, execuções, desaparecimentos forçados e mesmo ocultação de cadáveres não é estranha à realidade brasileira contemporânea. Relativamente à atuação dos órgãos de segurança pública, multiplicam-se, por exemplo, as denúncias de tortura, o que levou à recente aprovação da Lei $n^{\circ} 12.847 / 2013$, destinada justamente à implementação de medidas para prevenção e combate a esse tipo de crime. É entendimento da CNV que esse quadro resulta em grande parte do fato de que o cometimento de graves violações de direitos humanos verificado no passado não foi adequadamente denunciado, nem seus autores responsabilizados, criando-se as condições para sua perpetuação. ${ }^{20}$
\end{abstract}

A falta de conhecimento sobre as violações do passado tem, ainda, reflexos que vão além da repetição das violações de direito. O esquecimento forçado imposto às vítimas e a ocultação de seu sofrimento, causados pela forma como a história oficial foi reproduzida ao longo dos anos, a partir de registros do próprio Estado violador, omitindo as versões de uma grande parcela das testemunhas, são modos simbólicos de perpetuar as violações sofridas no passado. São vozes que permanecem sufocadas, sem encontrar eco nos documentos oficiais revelados e nos livros que se propõem a contar a "história oficial." Disso, decorre não somente prejuízos para as vítimas diretas, mas tem reflexos que afetam o modo de participação social na esfera pública e no seu destino político.

Enquanto "a história dos vencedores" era a única oficialmente reconhecida e reverberada pelo Estado, sabe-se hoje que essas vozes, embora sufocadas, não se mantiveram totalmente caladas. Com o fim da ditadura, muitos ex-perseguidos políticos, sobreviventes, familiares de vítimas e militantes de direitos humanos, mantiveram-se firmes na construção de uma agenda voltada a garantir o nãoesquecimento das violações de direitos humanos praticadas pelo Estado, e das histórias de resistência política que fizeram frente à repressão.

A luta contra o regime instaurado com o golpe de 1964 é, para Evelina

${ }^{20}$ BRASIL. Relatório da Comissão Nacional da Verdade. Brasília: CNV, 2014. v. 1, p. 976. Disponível em: <http://www.cnv.gov.br/images/pdf/relatorio/volume_1_digital.pdf>. Acesso em: 01 jun. 2015. 
Dagnino, parte fundamental do processo de alargamento da democracia iniciado com a promulgação da Constituição Federal de 1988. A autora faz referência às mobilizações das décadas de 1960 a 1980, em face da ditadura, pela anistia, pelas eleições diretas e ampliação de participação nas decisões políticas. ${ }^{21}$ Daí afirmarse que a luta no enfrentamento das violações em escala praticadas durante a última ditadura caminhou juntamente com a própria ampliação da cidadania no Brasil:

A então chamada nova cidadania, ou cidadania ampliada começou a ser formulada pelos movimentos sociais que, a partir do final dos anos setenta e ao longo dos anos oitenta, se organizaram no Brasil, em torno de demandas de acesso aos equipamentos urbanos como moradia, água, luz, transporte, educação, saúde, etc. e de questões como gênero, raça, etnia, etc. Inspirada na sua origem pela luta pelos direitos humanos (e contribuindo para a progressiva ampliação de seu significado) como parte da resistência contra a ditadura, essa concepção buscava implementar um projeto de construção democrática, de transformação social, que impõe um laço constitutivo entre cultura e política. ${ }^{22}$

Este movimento que, segundo a socióloga argentina Elizabeth Jelin, foi comum às ditaduras da América Latina, começou a mudar as relações dos sujeitos com o Estado. Até esse período, o ideal de cidadania era restrito praticamente aos homens de classe média, moradores das cidades e com educação formal. Nos anos de 1970, as mobilizações sociais, estavam prontas para a emergência "de novas maneiras de expressar as reivindicações sociais, políticas e culturais. A sociedade civil começou a ser mobilizada, gerando ações e demandas baseadas nos direitos e responsabilidades de cidadania."(2006, p. 165). ${ }^{23}$

José Murilo de Carvalho, defende que é neste momento da chamada "abertura política", que pôs fim às décadas de exceção de direitos, que a "cidadania, literalmente, caiu na boca do povo. Mais ainda, ela substituiu o próprio

\footnotetext{
${ }^{21}$ DAGNINO, Evelina. Sociedade civil, participação e cidadania: de que estamos falando? In: MATO, Daniel (coord.), Políticas de cidadania e sociedade civil em tempos de globalização. Caracas: FACES, Universidade Central de Venezuela, 2004. p. 95-110.

${ }^{22}$ Ibidem, p. 103.

${ }^{23}$ JELIN, Elizabeth. Cidadania Revisitada: Solidariedade, Responsabilidade e Direitos. In: JELI, Elizabeth; HERSHBERG, Eric (orgs) Construindo a Democracia: Direitos Humanos, Cidadania e Sociedade na América Latina. São Paulo: EDUSP, 2006. p. 155-179.
} 
povo na retórica política. Não se dizia mais "o povo quer isto ou aquilo", dizia-se "a cidadania quer'" (CARVALHO, 2013, p. 7).

Neste momento de expansão de direitos, imbuídos pelas lutas de resistência à ditadura, pela anistia política e pela redemocratização, as pautas desses grupos se estendiam para além das questões afetas à apuração das circunstâncias das violações de direitos humanos da ditadura. Constituíam, como afirma Maria da Glória Gohn, uma pauta traduzida na luta "para ter direito a ter direitos [e] não eram voltados apenas para si próprios, olhavam para o outro, até para poderem construir a própria identidade" (GOHN, 2010, p. 17).

Esses grupos, originários da luta pelo fim da ditadura e formados, em grande parte, por sobreviventes e familiares estão, ao longo das últimas décadas, atuando em torno de uma agenda comum que os legitima enquanto movimento social. Assim, segundo a definição de Gohn:

[...] possuem uma identidade, têm um opositor e articulam ou se fundamentam num projeto de vida e de sociedade [...], e têm contribuído para organizar e conscientizar a sociedade; apresentam conjuntos de demandas via práticas de pressão/mobilização; têm uma certa continuidade e permanência" (idem, p. 16)

Ainda conforme Gohn, esses grupos têm forte influência sobre as pautas e redefinições da esfera pública e grande poder de controle social, sendo capazes de construir inovações sociais e novos saberes. ${ }^{24}$

Trata-se, como afirma Ilse Scherer, da participação cidadã em sentido mais amplo, na tentativa de encaminhar suas ações em prol de "políticas sociais e públicas, protestos sociais, manifestações simbólicas e pressões políticas" (SCHERER - WARREN, 2006, p. 110).

Durante todas essas décadas, as tentativas de superar o legado desse período de exceção e violação de direitos, contou com o protagonismo desses grupos em inúmeras frentes, desde a luta pela anistia. ${ }^{25}$ Atuaram de modo

\footnotetext{
${ }^{24} \mathrm{GOHN}, 2010$, p.16.

${ }^{25}$ A União Brasileira de Mães, cassada em 1969; Movimento Feminino pela Anistia (MFPA), criado em 1975 pela advogada paulista Therezinha Godoy Zerbine e um grupo de mulheres paulistas, por meio do qual declaram assumir suas responsabilidades de cidadãs em prol da anistia; Comitês Brasileiros pela Anistia (CBAs), criados a partir de 1978 e espalhados em vários estados e que ganharam a força dos movimentos estudantis e da sociedade civil a partir de 1977. Em 1979, várias outras entidades já haviam se juntado à luta pela anistia: artistas, operários, profissionais liberais,
} 
contundente e pioneiro na busca por informações que levassem ao paradeiro dos corpos dos desaparecidos políticos, sua identificação e entrega aos familiares. ${ }^{26}$ Promoveram investigações em arquivos, propuseram denúncias no âmbito do Poder Judiciário e, também, internacionalmente. Trabalharam junto ao Poder Legislativo para a aprovação de marcos teóricos ${ }^{27}$, e na formação e composição de comissões de investigação e reparação às vítimas e familiares. ${ }^{28}$ Atuaram igualmente na localização, acesso e salvaguarda de documentos e por políticas de abertura de arquivos. Foi essa ação incansável que, muitas vezes, possibilitou a atuação de agentes do Estado, inclusive permitindo a elucidação de circunstâncias de torturas, assassinatos e desaparições forçadas.

A mobilização social de entidades brasileiras em torno das violações praticadas durante a ditadura também alcançou igualmente o cenário internacional. Ainda durante a ditadura a Anistia Internacional era constantemente acionada pelos familiares. No ano de 1979, uma parceria entre a mobilização social interna, formada por advogados e religiosos, e entidades internacionais, culminaria com o projeto Brasil Nunca Mais, primeiro relatório que trouxe a público as torturas cometidas no Brasil. ${ }^{29}$

Em 7 de agosto de 1995, instados pela desídia do Estado brasileiro em

etc. Informações dos livros "Anistia Ampla, Geral e Irrestrita: história de uma luta incompleta" e "Dossiê Ditadura: Mortos e Desaparecidos Políticos no Brasil (1964-1985)". 2a edição revista, ampliada e atualizada. São Paulo, 2009, p. 23.

${ }^{26}$ Nesta frente, se encontram, por exemplo, a descoberta de valas clandestinas na cidade de São Paulo e as primeiras buscas dos corpos dos militantes assassinados na Guerrilha do Araguaia. Para mais em detalhes consultar Dossiê Ditadura: Mortos e Desaparecidos Políticos no Brasil (19641985). $2^{\mathrm{a}}$ edição revista, ampliada e atualizada. São Paulo, 2009, p. 24-766.

${ }^{27}$ Como exemplo: Lei $n^{\circ} 9.140 / 1995$, por meio da qual o estado brasileiro assumiu sua responsabilidade pela morte e desaparecimento de pessoas, criando a Comissão Especial sobre Mortos e Desaparecidos Políticos - CEMDP, que tem, dentre outras atribuições, a indenização de familiares e a busca e identificação das ossadas; e Lei $n^{\circ} 10.559 / 2002$, pela qual são estabelecidos parâmetros de reparação de perseguidos políticos, criando a Comissão de Anistia do Ministério da Justiça - CA/MJ, que vem pautando também uma política de reparação simbólica e coletiva. Mais recentemente, estiveram envolvidos com a aprovação das leis de Acesso à Informação e lei que criou a Comissão Nacional da Verdade.

${ }^{28}$ Compõem a Comissão Especial sobre Mortos e Desaparecidos Políticos e a Comissão de Anistia, além das recentes comissões da verdade instaladas desde 2011 em diversos estados e municípios para a colaboração com a Comissão Nacional da Verdade. Secretaria Nacional de Justiça. Comissão de Anistia. Corte Interamericana de Direitos Humanos. Jurisprudência da Corte Interamericana de Direitos Humanos: Direito à vida, Anistias e Direito à Verdade. Tradução da Corte Interamericana dos Direitos Humanos. Brasília: Ministério da Justiça, 2014. Disponível em: <http://pt.slideshare.net/justicagovbr/01-derecho-a-la-vida-web>. Acesso em: 20 jul. 2015.

${ }^{29}$ Mais detalhes disponíveis em <http://bnmdigital.mpf.mp.br/\#!/bnm-historia>. Acesso em: 02 jun. 2015. 
esclarecer as circunstâncias de mortes e desaparecimentos dos militantes da Guerrilha do Araguaia (localizar, identificar e entregar suas ossadas), seus familiares acionaram a Comissão Interamericana de Direitos Humanos com o chamado Caso Gomes Lund versus Brasil. Submetido à Corte Interamericana de Direitos Humanos, em 26 de março de 2009, teve sua sentença proferida em 20 de novembro de 2014, por meio da qual o Brasil é responsabilizado internacionalmente "pelo desaparecimento forçado e, portanto, pela violação dos direitos ao reconhecimento da personalidade jurídica, à vida, à integridade pessoal e à liberdade pessoal."30

Em decorrência da mobilização internacional, a própria Corte Interamericana de Direitos Humanos vem sendo constantemente acionada por grupos sociais de diversos países signatários da Convenção Americana de Direitos Humanos, para apreciar denúncias que envolvem a prática de sistemáticas violações de direitos humanos em contextos de governos de exceção. O organismo vem formando uma vasta e consistente jurisprudência sobre a importância dos processos de enfrentamento das violações do passado, bem como da reconstituição e preservação da memória. ${ }^{31}$

Por meio das sentenças internacionais, grupos sociais internos recebem ainda mais subsídios para reforçar sua luta no âmbito doméstico, como no caso da recente sentença do Caso Gomes Lund. Foi, inclusive, na esteira da decisão da Corte para o caso, que o Ministério Público brasileiro inaugurou uma nova fase de investigações. ${ }^{32}$

A "mobilização jurídica em escalas nacional e transnacional", como descreve

\footnotetext{
${ }^{30}$ ORGANIZAÇÃO DOS ESTADOS AMERICANOS. Corte Interamericana de Direitos Humanos. Sentença no Caso Gomes Lund e outros (Guerrilha do Araguaia) versus Brasil. [24 nov. 2010]. Disponível em: <http://www.corteidh.or.cr/docs/casos/articulos/seriec_219_por.pdf>. Acesso em: 10 jun. 2015

${ }^{31}$ Jurisprudência publicada em português em: Secretaria Nacional de Justiça. Comissão de Anistia. Corte Interamericana de Direitos Humanos. Jurisprudência da Corte Interamericana de Direitos Humanos: Direito à vida, Anistias e Direito à Verdade. Tradução da Corte Interamericana de Direitos Humanos. Brasília: Ministério da Justiça, 2014. Disponível em <http://pt.slideshare.net/justicagovbr/01-derecho-a-la-vida-web>. Acesso em: 20 jul. 2015.

${ }^{32}$ Diversos grupos de trabalho foram criados no âmbito da instituição, promovendo uma série de investigações e medidas na esfera cível e criminal. Mais informações disponíveis em: $<$ http://pfdc.pgr.mpf.mp.br/institucional/grupos-de-trabalho/direito-a-memoria-e-averdade/apresentacao>. Acesso em: 29 abr. 2015. <http://2ccr.pgr.mpf.mp.br/coordenacao/gruposde-trabalho/justica-de-transicao/composicao/Portaria\%2021.pdf>. Acesso em: 29 abr. 2015.
} 
a investigadora Cecília Macdowell Santos, tem sido considerada, assim, um "elemento importante para o trabalho da justiça-memória no Brasil, onde se destaca o papel de mobilização e denúncia de ex-presos políticos e grupos de familiares de mortos e desaparecidos políticos" (SANTOS, 2010, p.128).

É neste cenário da última década que a pauta do enfrentamento do legado da ditadura ganhou novo fôlego no Brasil, abrindo-se ao movimento internacional da chamada justiça de transição, definida inicialmente pela professora de direito Ruti Teitel, enquanto "concepção da justiça associada a períodos de mudança política, caracterizados por respostas no âmbito jurídico, que têm o objetivo de enfrentar os crimes cometidos por regimes opressores do passado" (TEITEL, 2011, p.135).

Segundo o Relatório do Secretário-Geral ao Conselho de Segurança da Organização das Nações Unidas (ONU), de agosto de 2004, a justiça de transição compreende, ainda

[...]o conjunto de processos e mecanismos associados às tentativas da sociedade em chegar a um acordo quanto ao grande legado de abusos cometidos no passado, a fim de assegurar que os responsáveis prestem contas de seus atos, que seja feita a justiça e se conquiste a reconciliação. Tais mecanismos podem ser judiciais e extrajudiciais, com diferentes níveis de envolvimento internacional (ou nenhum), bem como abarcar o juízo de processos individuais, reparações, busca da verdade, reforma institucional, investigação de antecedentes, a destituição de um cargo ou a combinação de todos esses procedimentos." 33

Trata-se, segundo Paige Arthur, de buscar resposta "aos novos dilemas práticos" surgidos ao longo das últimas décadas nas inúmeras experiências pósconflito, sendo-lhe atribuída também a ideia de "rede internacional de indivíduos e instituições cuja coerência interna é mantida por conceitos comuns, objetivos práticos e distintos pedidos de legitimidade" (ARTHUR, 2011, p. 76).

Será também, conforme Paul Van Zyl, um esforço na "construção da paz sustentável, após um período de conflito, violência em massa ou violação sistemática dos direitos humanos comprometendo-se, em última análise, com a

\footnotetext{
${ }^{33}$ ORGANIZAÇÃO DAS NAÇÕES UNIDAS. O Estado de Direito e a justiça de transição em sociedades em conflito ou pós-conflito. Revista Anistia Política e Justiça de Transição, Brasília, Ministério da Justiça, n. 1, p. 325, jan.- jun. 2009.
} 
prevenção de novos abusos (ZYL, 2011, 47-48).

Mas, findado o regime político de exceção e promulgada uma Carta Constitucional há quase três décadas, por que então falar de justiça de transição no Brasil? Renan Quinalha, ao apresentar um recente estudo sobre os contornos do conceito de justiça de transição, apresenta como sendo seu primeiro passo a liberalização do regime. Segundo o autor, trata-se da liberalização de "uma situação de liberdades civis instituídas que não chegam a transformar, no entanto, o aparato do poder" (QUINALHA, 2013, p. 148-149), e que vai operar de modo superficial e pontual combinando questões intermediárias entre os dois extremos. Esta "abertura" ou "distensão", como são conhecidos esses momentos, contam com algumas iniciativas bastante conhecidas:

Menor grau de censura à imprensa, liberdade pouco maior de
organização e ação da classe operária, reintrodução de algumas
salvaguardas legais e individuais no ordenamento jurídico, tais
como habeas-corpus, a libertação da maioria dos prisioneiros
políticos, o retorno dos exilados políticos e a tolerância da oposição
política (QUINALHA, 2013, p. 183).

No Brasil, a "abertura" política se deu mais oficialmente a partir da aprovação da Lei de Anistia, em 28 de agosto de 1979, embora os anos antecedentes já tivessem iniciado esse processo, por meio de medidas distensionadoras. ${ }^{34}$

Um segundo passo da transição, segundo o autor, é a própria democratização, "momento mais avançado e expressivo do ponto de vista da garantia de direitos e das liberdades públicas comparativamente à liberalização, por demandar uma efetiva transformação do próprio regime político-autoritário." 35 Com a promulgação da Constituição Federal de 1988, estavam dadas as bases iniciais para a consolidação de um Estado Democrático.

No Brasil, o tempo transcorrido desde o fim da ditadura não foi suficiente para estancar a percepção de que ainda hoje restam pendentes muitas questões ainda não enfrentadas a fundo, tais como: o paradeiro dos desaparecidos, a responsabilização criminal e as reformas institucionais. Estes são exemplos de

\footnotetext{
${ }^{34}$ CARVALHO, 2003, p. 184.

${ }^{35}$ Idem, 2013, p.184.
} 
situações que desencadeiam a sensação de transição ainda inacabada, lenta e gradual, apontada pela narradora Rose Nogueira, uma das entrevistadas, e que são características da "falta de ruptura" presente em vários momentos da história do Brasil, como ocorreu, por exemplo, com o fim da escravidão e a Proclamação da República:

Nós temos uma história de, como é que eu vou chamar? De uma certa condescendência. Não temos rupturas, não temos grandes rupturas. Não temos grandes rupturas. [...] Olha, agora nós temos uma história lenta. Nossa transição é lenta. ${ }^{36}$

Essa "falta de ruptura", destacada pela narradora, é uma referência ao modo como se deu a "distensão" política brasileira pós-ditadura: com a permanência de atores "simpatizantes" do antigo regime, seus próprios agentes e colaboradores se mantendo presentes no cenário político e, ainda, com respaldo da interpretação de uma lei de anistia que perdoasse os crimes praticados pelos agentes de Estado.

No entanto, entre os momentos de abertura e de consolidação democrática, as transições, ao contrário do que se supõe, "não são momentos pontuais, mas processos que se arrastam no tempo e encadeiam diversos acontecimentos diferentes e, muitas vezes, até contraditórios entre si"(QUINALHA, 2013, p. 179). Além disso, uma temporalidade não se esvai de uma só vez. Ensina a memória, aliás, que várias delas coexistem.

Neste sentido é que o enfrentamento dos legados da ditadura se encontra presente no Brasil, tornando-se atual no contexto nacional a partir do ano de 2007. É neste momento que ocorre uma sucessão de eventos promovendo inigualável debate e visibilidade sobre os mecanismos de enfrentamento das questões ainda abertas da ditadura. Podem ser citados alguns dos eventos que fizeram parte desta guinada: a publicação o do Livro-relatório Direito à Memória e à Verdade, em 2007; a implementação das Caravanas da Anistia promovendo reparação de experseguidos políticos por diversas cidades e a oficialização do pedido de desculpas nos julgamentos de ex-perseguidos políticos, ambas no âmbito da Comissão de Anistia do Ministério da Justiça, a partir de 2008; ingresso, a partir de 2007, da entidade internacional Centro Internacional de Justiça de Transição no Brasil, com

\footnotetext{
${ }^{36}$ Entrevista concedida em 07 nov. 2014.
} 
atuação junto aos órgãos como o Ministério da Justiça e o Ministério Público ${ }^{37}$; a Ação de Descumprimento de Preceito Fundamental proposta pelo Conselho Federal da Ordem dos Advogados do Brasil no Supremo Tribunal Federal, em face da aplicabilidade da Lei de Anistia para os crimes praticados por agentes de Estado; sentença da Corte Interamericana de Direitos Humanos, em 2010; o III Plano Nacional de Direitos Humanos, trazendo como disposição expressa o Direito à Memória e à Verdade, também em 2010; a edição da Lei de Acesso à Informação, no ano de 2011; as ações criminais propostas pelo Ministério Público Federal em face de agentes da ditadura e, finalmente, a instalação da Comissão Nacional da Verdade, também em 2011.

Ao mesmo tempo em que a pauta da justiça de transição ganhava corpo, também a mobilização social parecia ganhar novo ânimo:

A partir daquele momento, para além da atuação intensa e histórica do movimento de familiares de mortos e desaparecidos e dos Grupos Tortura Nunca Mais, especialmente, do Rio de Janeiro e de São Paulo e o Movimento de Justiça e Direitos Humanos do Rio Grande do Sul (em especial nas perseguições no Cone Sul e Operação Condor), emergem novas frentes de mobilização segundo pautas amplas da Justiça de Transição. ${ }^{38}$

É também quando vão surgir diversos grupos com a autodenominação de "movimentos por memória, verdade e justiça". São dezenas de grupos e associações com atuação voltada à depuração do passado de violações de direitos humanos praticadas durante a ditadura e, portanto, com atuação direta no processo de transição democrática ${ }^{39}$. Esses grupos vão compor as novas agendas para a efetivação de mecanismos que contribuam com o enfrentamento das questões ainda abertas em relação às violações de Estado da ditadura.

O rol não taxativo de mecanismos eficazes no enfrentamento do legado de

\footnotetext{
${ }^{37} \mathrm{O}$ ICTJ é entidade sem fins lucrativos que já atuou em inúmeros cenários pós-conflito. No Brasil, tem auxiliado com a publicação e distribuição de material didático; cursos, palestras e seminários para trocas de experiência. Disponível em: <https://www.ictj.org/es/our-work/regions-andcountries/brasil>. Acesso em: 15 jun. 2015.

${ }^{38}$ ABRÃO, Paulo; TORELLY, Marcelo. As razões da eficácia da Lei de Anistia no Brasil e as Alternativas para a Verdade e a justiça em relação às graves violações de direitos humanos ocorridas durante a ditadura militar (1964 - 1985). In.: PRADO, Alessandro Martins; BATISTA, Cláudia Karina Ladeia; SANTANA, Isael José (Orgs.).Direito à Memória e à Verdade e Justiça de Transição no Brasil: uma história inacabada! Uma República inacabada!. 1.ed. Curitiba: CRV, 2011. p. 189-234.

${ }^{39}$ Idem, 2011, p. 212.
} 
violações, estruturado a partir das diversas experiências concretas, compõe alguns núcleos, que passam a servir de guia e paradigma no enfrentamento das questões que permeiam as violações sistemáticas de direitos humanos. As medidas adotadas nesse processo englobam ações como revelação da verdade, reforma das instituições que praticaram os abusos, a promoção da reconciliação ${ }^{40}$,a oficialização do pedido de desculpa pelo Estado, a efetivação de uma política de reparações, publicação de memórias e "todo tipo de acerto de contas relacionados aos crimes e sofrimentos passados" ${ }^{\prime 1}$.

No campo da reparação, que visa exatamente reconhecer e compensar os danos causados, tem havido considerável expansão do conceito, para além do aspecto pecuniário e individual, abarcando também danos morais e coletivos. A política conta com a participação ativa de ex-perseguidos políticos e familiares, desde a criação da Comissão Especial sobre Mortos e Desaparecidos Políticos CEMDP, ainda no ano de 1995 e, mais recentemente, com a Comissão de Anistia, em funcionamento desde 2002.

Na busca pela verdade, as investigações sobre as circunstâncias em que se deram as violações, os agentes, modus operandi, colaboradores e a totalidade de danos e vítimas é uma pauta que conta com o pioneirismo da mobilização social. Sua atuação costuma fomentar a criação de comissões da verdade enquanto mecanismo de apuração. No caso brasileiro, a Comissão Nacional da Verdade, criada no ano de 2011, apesar de não contar com processo participativo da sociedade, como sugerem os indicadores sobre o melhor funcionamento desse tipo de mecanismo, ela foi também fruto do III PNDH, importante documento gerado a partir de um conjunto de conferências nacionais de participação social. Houve, ainda, sistemático acompanhamento, por parte dos diversos grupos sociais, em relação ao trabalho da $\mathrm{CNV}{ }^{42} \mathrm{~A}$ mobilização social promoveu, ainda, a criação de dezenas de comissões da verdade no âmbito dos estados, municípios e entidades de modo a complementar o trabalho da comissão nacional.

${ }^{40}$ ZYL, op. cit., p. 47

${ }^{41}$ TEITEL, op. cit., p. 159.

${ }^{42} \mathrm{Um}$ exemplo deste acompanhamento são os relatórios do ISER, sobre as atividades da CNV. Disponível em:<http://www.iser.org.br/pdfs/II_relatorio_CNV_ISER_WEB_160713_ALT.pdf.>Acesso em: 25 mai. 2015 
Na luta pela responsabilização criminal, surgem as ações de investigação, processos judiciais, apuração de responsabilidades e punição, atividades que vem sendo também suscitadas pela mobilização social e promovidas pelo Ministério Público ${ }^{43}$.

Também a depuração das instituições públicas por meio de reformas institucionais e legislativas tem sido reivindicadas pelas mobilizações. A reformulação das forças militares e policiais também são constantes reivindicações desses grupos sociais, que tem tratado a questão em diálogo com os repetidos e sistemáticos episódios de violência policial que culminam com práticas que vão desde a tortura até desaparições forçadas.

Por fim, a memória surge como mais um dos eixos da justiça de transição com aplicabilidade também no Brasil e que conta com a mobilização social em um processo novo, porém, em expansão. Como elemento de enfrentamento do passado de violações, a memória surge calcada na reconstituição e preservação das recordações, baseando-se na diversidade de depoimentos e de documentos para formar todo um tecido da memória social. Nesse processo, acaba por permear os demais. À medida que se constrói uma memória sobre as experiências daquele período, partindo das vozes de quem vivenciou a experiência, igualmente se trabalham, por exemplo, aspectos como a busca pela verdade e a reparação moral e coletiva.

\footnotetext{
${ }^{43}$ Este tem sido considerado um dos pontos de maior conflito nos processos de transição, refletindo polarizações que se perpetuam, principalmente sobre as bases do perdão e de interpretações restritivas da anistia política, como aponta Renan Quinalha. Neste aspecto, o caso brasileiro é bem emblemático. A Lei de Anistia aprovada no ano de 1979 e que permitiu a libertação de inúmeros presos políticos e o retorno de outros muitos que estavam no exílio, foi recebida por parte de seus intérpretes ao longo das últimas décadas, como um impeditivo legal para a responsabilização dos agentes de Estado. O tema, no entanto, já vem sendo enfrentado pela Corte Interamericana de Direitos Humanos de modo a garantir a inaplicabilidade das auto-anistias aos crimes contra a humanidade, assim consideradas as violações de direitos humanos praticadas de modo sistemático. $\mathrm{Na}$ própria sentença aplicada ao caso brasileiro, a Corte cita outros casos em que considerou inválidas as anistias. A questão ainda é objeto de judicialização no âmbito interno, tanto na ADPF 153 quanto em outra ação igualmente provocada no Supremo Tribunal Federal. Na ADPF 153, em cuja sentença de 28 abr. 2010, o STF decidiu, por sete votos a dois, pela validade da Lei de Anistia, ainda resta pendente a apreciação de embargos de declaração. Há, ainda no âmbito do STF, outra ação versando sobre o caso, a ADPF 320. Trata-se de ação promovida pelo Partido Socialista Brasileiro (PSOL), pleiteando a revisão da Lei de Anistia. Para maiores detalhes, consultar processos

<http://www.stf.jus.br/portal/processo/verProcessoAndamento.asp?incidente=2644116 $<$ http://www.stf.jus.br/portal/processo/verProcessoAndamento.asp?incidente=4574695> em: em: 10 jun. 2015. 
Segundo o filósofo francês Paul Ricceur, a memória é a operação pela qual as coisas voltam ao espírito do sujeito, sendo o seu vínculo com suas experiências vivenciadas no passado, de modo a garantir a "continuidade temporal da pessoa." Para o autor, trata-se de uma viagem do sujeito no tempo dele mesmo, que vai permitindo que ele se lembre de si enquanto vai lembrando de algo:

Essa continuidade permite-me remontar sem ruptura do presente vivido até os acontecimentos mais longínquos de minha infância. De um lado, as lembranças distribuem-se e se organizam em níveis de sentido, em arquipélagos, eventualmente separados por abismos, de outro, a memória continua sendo a capacidade de percorrer, de remontar no tempo, sem que nada, em princípio, proíba prosseguir esse movimento sem solução de continuidade (RICCEUR, 2007, p.108).

Desenvolvendo a ideia de Santo Agostinho sobre o aspecto interior da memória, Ricceur resgata o espaço interno no qual a memória individual se aloca no sujeito, enquanto "vasto palácio", uma espécie de repositório das inúmeras lembranças, do qual o sujeito se vale por meio da memória. ${ }^{45}$ Recorrendo a este depósito para lembrar, somos surpreendidos por lembranças que se precipitam, saltam, pulam ou, ao contrário, se escondem e desaparecem.

Esse arcabouço individual, no entanto, que compõe a memória individual, memória pessoal e interior ou, ainda, a memória autobiográfica, não se forma, segundo o sociólogo francês Maurice Halbwachs, se não estiver conectada com o contexto social no qual o sujeito esteve ou está inserido. ${ }^{46}$ Isto se dá, para o autor, porque "jamais estamos sós" e, mesmo que os outros não estejam presentes materialmente conosco, sempre carregamos em nós certa quantidade de pessoas.

Quando um homem entra em sua casa sem estar acompanhado por ninguém, sem dúvida, durante algum tempo, "ele andou só", na linguagem corrente - mas ele esteve sozinho apenas na aparência, pois, mesmo nesse intervalo, seus pensamentos e seus atos se explicam por sua natureza de ser social e porque ele não deixou sequer por um instante de estar encerrado em alguma sociedade. ${ }^{47}$

Seguindo a análise da constituição da memória no contexto social,

\footnotetext{
${ }^{44}$ RICOEUR, Paul. A memória, a história, o esquecimento. Campinas: UNICAMP, 2007. p. 107.

${ }^{45}$ RICCEUR, Paul. op. cit., p. 109.

${ }^{46}$ HALBWACHS, Maurice. A Memória Coletiva. São Paulo: Centauro, 2003. p. 71.

${ }^{47}$ HALBWACHS, Maurice. op. cit., p. 42.
} 
Halbwachs trouxe luz à existência de uma memória social, coletiva, exterior, ou, ainda, histórica, forjada e enriquecida na diversidade de lembranças de indivíduos que compõem um determinado grupo em um determinado contexto espacial e temporal. $^{48}$

Ao tratar da memória em seus aspectos individuais e coletivos, o sociólogo Michael Pollak destaca que às experiências diretamente vividas se somam ainda as experiências dos outros na formação de nosso arcabouço de lembranças:

Quais são, portanto, os elementos constitutivos da memória, individual ou coletiva? Em primeiro lugar, são os acontecimentos vividos pessoalmente. Em segundo lugar, são os acontecimentos que eu chamaria de "vividos por tabela", ou seja, acontecimentos vividos pelo grupo ou pela coletividade à qual a pessoa se sente pertencer. São acontecimentos dos quais a pessoa nem sempre participou, mas que, no imaginário, tomaram tamanho relevo que, no fim das contas, é quase impossível que ela consiga saber se participou ou não. Se formos mais longe, a esses acontecimentos vividos por tabela vêm se juntar todos os eventos que não se situam dentro do espaço-tempo de uma pessoa ou de um grupo. ${ }^{49}$

O avivamento das memórias sociais, no processo de enfrentamento das violações do passado, que tem em seu núcleo o diálogo entre passado, presente e futuro, atuará como colaborador para a formação de uma nova cultura política necessária ${ }^{50}$. Poderá atuar como mecanismo mediador de gerações, reforçando a capacidade de transmissão de valores, conteúdos e atitudes, enquanto constituintes da nova cultura social ${ }^{51}$.

A partir do resgate do conjunto de vivências e impressões, lembranças e esquecimentos que, durante muito tempo, permaneceram na clandestinidade, a memória social, seria traduzida enquanto imperativo para a construção de uma sociedade mais justa e madura, capaz de projetar seu futuro no esforço presente de dar novo sentido às violações do passado ${ }^{52}$. Esse processo de busca de

\footnotetext{
${ }^{48}$ HALBWACHS, Maurice. op. cit., p. 98.

${ }^{49}$ POLLAK, Michael. Memória e Identidade Social. Estudos Históricos, Rio de Janeiro, v. 5, n. 10 , 1992, p. 200-212.

${ }^{50}$ TORELLY, Marcelo D. Justiça Transicional, Memória Social e Senso Comum Democrático: notas conceituais e contextualização do caso brasileiro. In: Repressão e Memória Política no Contexto Íbero-Brasileiro: Estudos sobre Brasil, Guatemala, Moçambique, Peru e Portugal. Brasília: Ministério da Justiça, Comissão de Anistia; Portugal: Universidade de Coimbra, Centro de Estudos Sociais, 2010.p. 104-123..

${ }^{51} \mathrm{BOSI}$, Ecléa. O tempo vivo da memória. São Paulo: Ateliê editorial, 2003. p. 15.

${ }^{52}$ FILHO, José Carlos Moreira. Dever de memória e a construção da história viva: a atuação da Comissão de Anistia do Brasil na concretização do direito à memória e à verdade. In: Repressão e
} 
evocações das lembranças e impressões sociais é que teria a capacidade de projetar sobre a própria sociedade uma potência de cura, reconciliação e transformação ${ }^{53}$, surgindo a memória social como exercício participativo na construção da nova sociedade pós- conflito.

Ainda, a memória social é, segundo os ensinamentos de Pollak, um campo de batalhas entre vencedores e vencidos onde está em disputa, todo o tempo, aquilo que será lembrando ou esquecido. Em geral, o segundo grupo acaba por ter seus "gritos" abafados pela "história oficial", narrada em documentos oficiais por meio da visão de apenas um grupo: o dos vencedores. ${ }^{54}$ No entanto, mesmo abafados, não deixam de existir. Seguem sobrevivendo em seus núcleos, passando informações de geração a geração, exatamente como vem acontecendo com núcleos de familiares, sobreviventes e militantes de direitos humanos que atuam na temática das violações da ditadura. Suas experiências sempre existiram e seguiram sendo reavivadas, como coloca o autor, na condição de memória subalterna, subterrânea:

A despeito da importante doutrinação ideológica, essas lembranças durante tanto tempo confinadas ao silêncio e transmitidas de uma geração a outra oralmente, e não através de publicações, permanecem vivas. (POLLACK, 1983, p.5).

Para o autor, ainda, à medida que essas vozes se fazem mais presentes em cena, mais se faz evidente "o fosso ideológico", entre aquela comunidade, cujas histórias de vida e necessidades vinham sendo abafadas, e o próprio Estado que vem apresentando uma narrativa incompleta, parcial e muitas vezes, mentirosa. $\mathrm{O}$ fenômeno que se segue à ocupação do espaço público por essas vozes subterrâneas, permite que "reivindicações múltiplas e dificilmente previsíveis se acoplem a essa disputa da memória." 55

\footnotetext{
Memória Política no Contexto Íbero-Brasileiro: Estudos sobre Brasil, Guatemala, Moçambique, Peru e Portugal. Brasília: Ministério da Justiça, Comissão de Anistia; Portugal: Universidade de Coimbra, Centro de Estudos Sociais, 2010. p. 186-227

${ }^{53}$ RICOEUR, Paul. O bom uso das feridas da memória. In: Les résistances sur le Plateau Vivarais-Lignon (1938-1945): Témoins, témoignages et lieux. de mémoires. Les oubliés de I'histoire parlent. Editions du Roure, 2005.

${ }^{54}$ POLLACK, Michael. Memória, esquecimento, silêncio. In: Revista Estudos Históricos, Rio de Janeiro, v. 2, p. 4, mar. 1989.

${ }^{55}$ Idem, 1983, p.4.
} 
Um dos elementos mais relevantes neste processo, segundo Pollak, é, justamente, a história oral, já que

Ao privilegiar a análise dos excluídos, dos marginalizados e das minorias, a história oral ressaltou a importância de memórias subterrâneas que, como parte integrante das culturas minoritárias e dominadas, se opõem à "memória oficial". ${ }^{56}$

Quando a memória social a que se faz referência está relacionada às lembranças de um passado de violências sistemáticas, esta polaridade se faz clara em relação ao obscurantismo e negacionismo imposto, em geral, pelos agentes, cúmplices e apoiadores das violações. Em se tratando de episódios de violação de direitos humanos, a falta das lembranças fomenta e possibilita o esquecimento das violências e até mesmo a inexistência total de sua prática no imaginário social, principalmente, para as gerações que não vivenciaram diretamente os episódios. No caso da ditadura brasileira, isto ficou bem marcado com a ausência de informações mínimas sobre as circunstâncias em que se deram as mortes, desaparições, torturas, banimentos, demissões e demais violências praticadas pelo próprio estado com o apoio da várias áreas privadas e internacionais. Durante muitos anos não se estudou a ditadura nas escolas brasileiras. A imprensa ou a arte tão pouco se interessavam pelos personagens daquela época, nem pelo seu enredo. A batalha estava vencida e a história bem direcionada ao esquecimento das violações.

Assim, as memórias que se quer salvaguardar e se ver emergir quando se fala em mecanismos de enfrentamento das violações de direitos humanos do passado, ou seja, por meio da justiça de transição, são justamente aquelas antes veladas: dos vencidos, chamadas por Michael Pollak de memórias subalternas. 0 campo onde antes predominava as recordações de "um lado", contará agora com uma diversidade de vozes, na condição de elemento de grande importância no enfrentamento das questões jurídicas, políticas e sociais que permeiam um legado de violações do passado.

Estudos de casos de superação dos legados de violações, têm considerado a memória e os direitos humanos enquanto pontos que se cruzam não só em suas trajetórias, mas também naquilo em que, de fato, buscam alcançar, como destaca o

\footnotetext{
${ }^{56}$ Ibidem, p. 4.
} 
professor alemão Andreas Huyssen (2014, p. 196):

Os dois se interessam pela violação e a proteção dos direitos humanos básicos, e ambos têm de recorrer à história para fazê-lo. Ambos querem reconhecer, se não corrigir, os erros e as injustiças do passado, e ambos projetam e imaginam um futuro melhor para o mundo. Ambos brotaram, até certo ponto, de discursos jurídicos, morais e filosóficos sobre o genocídio e as violações dos direitos humanos após a Segunda Guerra Mundial.

Essa relação, nem sempre de fácil identificação e compreensão, vê-se sustentada na perspectiva de direitos humanos enquanto processo constante e inacabado de conquista e expansão de modos de vida com mais dignidade ${ }^{57}$, tornando imperiosa a reconstituição e perpetuação de sua trajetória. Nesse sentido, como define Huyssen, "somente a memória das violações dos direitos humanos pode alimentar o futuro dos direitos humanos no mundo, fornecendo um elo substancial entre passado e futuro." ${ }^{58}$ Ou seja, para avançar em garantias e direitos é preciso olhar para trás.

A interseção parece ter aflorado no cenário internacional a partir das barbáries do Holocausto, despertando parte dos países que compunham as cúpulas políticas para a necessidade de pensar estratégias imperativas que não permitissem que Auschwitz, ou algo parecido, se repetisse jamais. ${ }^{59}$

É certo que muitas histórias de violações em escala se deram antes deste episódio. No entanto, também é possível afirmar que foi justamente a partir desta barbárie que se impulsiona um pensamento em relação às vítimas do passado e de outros episódios como, por exemplo, da escravidão, das eras de conquistas, do colonialismo. É quando se descobre, como lembra o filósofo espanhol Reys Mate, a "fraternidade das vítimas", a partir da qual todas as memórias contemporâneas se fundem (2009, p. 31).

Posteriormente, com outras duas ondas de sistemáticas violações de direitos humanos em diversos países e continentes, surge o que Huyssen chama "cristalização da política global dos memoriais", processo ocorrido na década de 1990: as transições democráticas pós-ditaduras na América Latina e pós-Apartheid,

\footnotetext{
${ }^{57}$ FLORES, Joaquin Herrera. A (re) invenção dos direitos humanos. Trad. Carlos Roberto Diogo Garcia, Antonio H. G. Suxberger e Jefferson A. Dias. Florianópolis: Fundação Boiteux, 2009, p. 27. ${ }^{58}$ HUYSSEN. 2014. op. cit., p. 196.

${ }^{59}$ FILHO. 2010.op. cit., p. 188.
} 
na África do Sul e os processos mais recentes de limpeza étnica e milhares de assassinatos em Ruanda e nos Balcãs, antiga luguslávia. ${ }^{61}$

À medida que os direitos humanos foram ganhando corpo no debate internacional, do mesmo modo também o discurso da memória foi ascendendo. Emergia, naquele momento histórico, o discurso sobre a necessidade de reconstituição das experiências, sobretudo das vítimas, no sentido de que "a dignidade das vítimas, suas lutas e seu destino devessem ser preservados na memória, sobretudo porque era um objetivo expresso dos mestres do genocídio obliterar qualquer lembrança das vítimas." ${ }^{2}$ Aquele projeto de esquecimento deveria ser não só combatido, mas evitado de modo radical. E por ser um projeto de esquecimento, no qual se busca a eliminação não só das vítimas mas também das recordações de suas experiências, uma das formas de ser evitado é justamente pela memória.

A imperiosidade de se conhecer o passado de violações surge, assim, como modo de superação não somente para as vítimas diretas, mas também de heranças sociais, políticas e culturais, ideia que permeia a fala de Elza Lobo, uma das narradoras da pesquisa, quando afirma que "as pessoas precisam saber do que aconteceu" e que "se você deixa como se fosse um passado escondido você não faz com que as pessoas saibam o que aconteceu":

[...] eu acho importante que essa memória venha à tona para que as pessoas realmente conheçam para que não mais aconteça. Não acho também que estamos tão livres de não acontecer. Depende dos momentos históricos que se vive. ${ }^{63}$

A necessidade de revisitar os acontecimentos do passado em uma conotação coletiva da memória, quando se trata de sistemáticas violações de direitos humanos, é muito clara, também, para a narradora Rose Nogueira:

E tudo a gente só aperfeiçoa se a gente tiver memória, se a gente tiver a busca da verdade, de como aconteceram as coisas. Nós precisamos saber disso tudo. Se a gente não tiver um aprofundamento histórico, a gente também cai numa certa mediocridade do cotidiano. É bom saber, porque você está aqui hoje viva, pensa assim e tudo. Isso seria motivo até de aprofundar com a juventude, para que cada um pensasse assim e formasse

\footnotetext{
${ }^{61}$ HUYSSEN, op. cit., p.139.

62 HUYSSEN, op. cit., p.200.

${ }^{63}$ Entrevista concedida em 08 nov. 2014.
} 
esse coletivo legal. ${ }^{64}$

Ao contrário, como já mencionado, manter o passado na sombra e insistir na negativa de acontecimentos e responsabilidades, colaboram sobremaneira com o sentimento coletivo de que "nada aconteceu". Ao negar as práticas de violência, elas acabam por se tornar invisíveis, com a tendência de serem repetidas de modo confortável, sem causar espanto ou indignação social. Esta parece ser uma das grandes preocupações de Elza Lobo, que, a todo o momento, insiste no objetivo das ações de memória que participa: "para que (a ditadura) nunca mais aconteça." 65

Também a pauta voltada expressamente à reconstituição da memória social referente ao período da ditadura é recente no Brasil, tanto em relação às políticas advindas do Estado quanto de iniciativas da sociedade. No entanto, mesmo quando não se falava no termo justiça de transição, também a memória já vinha sendo reconstituída, principalmente, pelos grupos sociais formados por familiares, militantes de direitos humanos e ex-perseguidos políticos.

Enquanto agrupavam documentos e depoimentos, na intenção primeira de buscar as evidências dos crimes, as verdades sobre as mortes, desaparições e torturas, provas para as reparações, esses movimentos foram, ainda que de modo inconsciente e reflexo, colaborando com a reconstituição da memória de toda uma geração. À medida que suas atividades de busca pela verdade se desenvolviam, formavam também acervos de depoimentos e um complexo conjunto de documentos. ${ }^{66}$

A este processo, esses grupos têm também promovido conscientemente ações de registro e propagação de suas vivências durante a ditadura, por meio de exposições artísticas e fotográficas, execução de filmes e documentários, organização e disponibilização de arquivos, registros orais, manifestações, datas comemorativas, cultos, e construção de memoriais, dentre outros.

Na esfera do Estado, também as ações de memória vêm se desenvolvendo

\footnotetext{
${ }^{64}$ Entrevista concedida em 07 nov. 2014.

${ }^{65}$ Entrevista concedida em 08 nov. 2014.

${ }^{66}$ Caso dos requerimentos de anistia junto à Comissão de Anistia, hoje com aproximadamente $70 \mathrm{mil}$ requerimentos, formando o maior acervo nacional de narrativas em primeira pessoa, na voz dos próprios perseguidos políticos.
} 
na última década. A Comissão Especial sobre Mortos e Desaparecidos Políticos, por meio, do projeto "Direito à Memória e à Verdade", aponta algumas de suas ações neste caminho:

a) a publicação e distribuição do relatório Direito à Memória e à Verdade em escolas públicas; b) outras três publicações a fim de ressaltar aspectos relevantes da luta contra o regime militar; c) a exposição fotográfica "A ditadura no Brasil 1964-1985"; e d) o projeto "Memorial Pessoas Imprescindíveis", que consiste em painéis e esculturas colocados em diversos locais públicos. ${ }^{67}$

A Comissão de Anistia do Ministério da Justiça, no ano de 2008, por meio das Caravanas de Anistia, passou a realizar sessões itinerantes para apreciar seus requerimentos de anistia. Assim, "transferiu seu trabalho cotidiano das quatro paredes de mármore do Palácio da Justiça para a praça pública, para escolas e universidades, associações profissionais e sindicatos, bem como a todo e qualquer local onde perseguições ocorreram."

Nesses espaços, possibilitou que milhares de testemunhas tornassem públicas, pela primeira vez, as suas experiências de luta e as violações sofridas. Com a ampliação de acesso ao seu trabalho, por meio das Caravanas, uma multiplicidade de vozes compõem hoje o maior acervo de depoimentos de sobreviventes e familiares de mortos e de desaparecidos políticos da ditadura no Brasil:

Com a ampliação do acesso público aos trabalhos da Comissão, cresceram exponencialmente $o$ número de relatos de arbitrariedades, prisões, torturas, mas também pode-se romper com o silêncio para ouvir centenas de depoimentos sobre resistência, coragem, bravura e luta. ${ }^{69}$

Nesta diversidade de vozes reside a possibilidade de ampliar a reflexão social sobre os acontecimentos, abrindo margem não só ao debate público, mas também, às escolhas sobre caminhos a serem refeitos e trilhados:

\footnotetext{
${ }^{67}$ ORGANIZAÇÃO DOS ESTADOS AMERICANOS. Corte Interamericana de Direitos Humanos. Sentença no Caso Gomes Lund e outros (Guerrilha do Araguaia) versus Brasil. [24 nov. 2010]. Dsiponível em: <http://www.corteidh.or.cr/docs/casos/articulos/seriec_219_por.pdf>. Acesso em: 10 jun. 2015.

${ }^{68}$ RODEGHERO, Carla Simone; GUAZZELLI, Dante Guimarães; DIENSTMANN, Gabriel. Não calo, grito: Memoria visual da ditadura civil-militar no Rio Grande do Sul. Porto Alegre: Tomo Editorial, 2013. 1.ed.

${ }^{69}$ Idem
} 
O testemunho compartilhado pelo perseguido político num espaço coletivo como o das Caravanas propicia a reconstituição da história, o enfrentamento do passado e uma intensa valorização dos ideais e vivências. Aqueles que as escutam são sensibilizados a compreendê-las sob o prisma dos atores sociais que, embora pretensamente invisibilizados pela política da amnesia, foram protagonistas da história. ${ }^{70}$

O órgão também tem fomentado ações de memória em parceria ou com total participação da sociedade civil por meio do Projeto Marcas da Memória ${ }^{71}$, que

Expande ainda mais a reparação individual em um processo de reflexão e aprendizado coletivo, fomentando iniciativas locais, regionais e nacionais que permitam àqueles que viveram um passado sombrio, ou que a seu estudo se dedicaram, dividir leituras do mundo que permitam a reflexão crítica sobre um tempo que precisa ser lembrando e abordado sob auspícios democráticos. ${ }^{72}$

No final de 2014, por ocasião da publicação do Relatório Final da Comissão Nacional da Verdade, o órgão recomendou a adoção de uma série de medidas de "preservação da memória das graves violações de direitos humanos", propondo a instituição de demarcações nos meios urbanos e rurais e a instauração do Museu da Memória, em Brasília. Propôs também a revogação de homenagens realizadas a agentes públicos e privados, que atuaram diretamente nas práticas de violações ou em sua colaboração.

Outras medidas protetoras e promotoras da memória foram igualmente recomendadas: a continuidade de localização e abertura de arquivos; a alteração de currículos escolares referente à história política; a retificação de registros de óbito; a retificação de registros em sistemas de segurança pública que ainda penalizam vítimas da ditadura; modificação de currículos militares; e a proibição de eventos de comemoração do golpe. ${ }^{73}$ Todas essas medidas estão relacionadas à

\footnotetext{
${ }^{70}$ ABRÃO, Paulo et. al. Educação e Anistia Política: idéias e práticas emancipatórias para a construção da memória, da reparação e da verdade no Brasil. In: Repressão e Memória Política no Contexto Íbero-Brasileiro: Estudos sobre Brasil, Guatemala, Moçambique, Peru e Portugal. Brasília: Ministério da Justiça, Comissão de Anistia; Portugal: Universidade de Coimbra, Centro de Estudos Sociais, 2010. p. 60-87.

${ }^{71}$ Suas ações estão divididas nos seguintes campos: audiências públicas, história oral, chamadas públicas defomento à iniciativas da sociedade civil e publicações.

${ }^{72}$ RODEGHERO, Carla Simone; GUAZZELLI, Dante Guimarães; DIENSTMANN, Gabriel. Não calo, grito: Memoria visual da ditadura civil-militar no Rio Grande do Sul. Porto Alegre: Tomo Editorial, 2013. 1.ed.

${ }^{73}$ BRASIL.Relatório da Comissão Nacional da Verdade. Brasília: CNV, 2014. v. 1, p. 976. Disponível em: <http://www.cnv.gov.br/images/pdf/relatorio/volume_1_digital.pdf>. Acesso em: 01
} 
reconstituição e preservação da memória social do período da ditadura.

$\mathrm{Na}$ ideia de reconstituir e preservar a memória social, ainda outros mecanismos têm sido adotados como forma de enfrentamento dos legados dos períodos de violação. São os chamados "lugares de memória". A partir do desaparecimento das sociedades-memória, o historiador francês contemporâneo Pierre Nora levantou a questão da necessidade de lugares no mundo exterior onde a memória pudesse ser cristalizada, uma vez que já não era construída de modo natural no interior dos sujeitos de uma coletividade fragmentada. ${ }^{74}$

Para a tarefa de materializar a memória, Nora cunhou o termo "lugar de memória", enquanto espaço de refúgio da memória social que já não se faz mais no interior dos sujeitos e dos grupos, amparando-se, assim, no mundo exterior para subsistir. Surgem como "lugares de refúgio, santuário das fidelidades espontâneas e das peregrinações do silêncio" onde "um fio invisível liga os objetos sem uma relação evidente". ${ }^{75}$ Para o autor, ainda, os lugares de memória são formados a partir da "constituição gigantesca e vertiginosa do estoque material daquilo que nos é impossível lembrar" e "daquilo que poderíamos ter necessidade de nos lembrar" (NORA, 1983, p. 15). Por meio de signos materiais e imateriais e ainda monumentos e museus, que possam imprimir e externalizar o que antes era transmitido pelas sociedades-memória, a razão de ser desses espaços, reside na sua intenção de retornar o tempo passado para o presente, bloquear o esquecimento, tornar a morte imortal e materializar o imaterial.

Ainda que da reflexão de Nora, os "lugares de memória" apontem, em um primeiro momento como resultado de uma sociedade catastroficamente fragmentada, a força destes elementos dentre aqueles que constituem as memórias, principalmente, as de grupos, é trazida por Pollak:

Entre eles incluem-se evidentemente os monumentos, esses
lugares da memória analisados por Pierre Nora, o patrimônio
arquitetônico e seu estilo, que nos acompanham por toda a nossa
vida, as paisagens, as datas e personagens históricas de cuja
importância somos incessantemente relembrados, as tradições e
costumes, certas regras de interação, o folclore e a música, e, por

jun. 2015.

${ }^{74}$ NORA, Pierre. Entre memória e História. A problemática dos lugares. Revista Projeto História, São Paulo, v. 10, p. 8, dez. 1993

${ }^{75}$ NORA, op. cit., p. 27. 
que não, as tradições culinárias. ${ }^{76}$

A utilização destes mecanismos no enfrentamento das violações do passado surge como "atividade política e social", que visa colaborar com a perpetuação da memória no concreto, no espaço, gesto, imagem e objeto. ${ }^{77}$ Neste intento, são, ainda, projetos que potencializam a participação social, o debate e a reflexão política:

[...] projetos de memorialização, através de todas as suas fases, têm o potencial de envolver um público mais amplo no debate e discussão sobre o passado e sua visão para o futuro. [...] a memorialização pode servir para promover o debate e engajamento público e construtivo. [...] os locais de memória podem ser ativados através de programas de educação para garantir o diálogo e o engajamento público existente. ${ }^{78}$

Diversos países, que passaram por períodos de graves atentados aos direitos humanos, vem fazendo uso desses mecanismos capazes de salvaguardar e materializar a memória coletiva das violações e das lutas de resistência como meio valioso de reparação simbólica às vítimas e de debate público voltado à superação dos traumas sociais e à não-repetição das violências, como explica documento publicado pelo Centro Internacional de Justiça de Transição - ICTJ, especialmente, para um caso de memorialização no Brasil, referente à sede da União Nacional dos Estudantes - UNE:

Muitos países estão tratando também de responder à dimensão coletiva e simbólica das violações de direitos humanos mediante os chamados processos de "memorialização" que buscam criar memoriais públicos ou ressignificar espaços públicos. É este o caso, dentre outros, do Chile, Argentina, Marrocos, Camboja e etc. São representações cívicas ou atividades comemorativas que se relacionam com eventos do passado e se situam ou realizam em espaços públicos. Estão desenhados para evocar uma reação ou um conjunto de rações específicas incluindo um reconhecimento público do evento passado e de pessoas ou coletivos neles representados, uma reflexão pessoal ou coletiva a respeito de um acontecimento passado; estão desenhados para fomentar um conhecimento, ocupar-se do legado na atualidade do acontecimento passado e estimular o diálogo em torno dele.

\footnotetext{
${ }^{76}$ POLLAK, 1989, op. cit. p. 3-15.

${ }^{77}$ NAIDU, Ereshnee. Da Memória à Ação: Um Kit de Ferramentas para Memorialização em Sociedades pós-conflito. Brasília: Ministério da Justiça, Comissão de Anistia, 2010.

${ }^{78}$ NAIDU, op. cit., p. 16.
} 
Propõem um enfoque integrado entre passado e futuro. ${ }^{79}$

Para a Coalisão Internacional de Sítios de Consciência ${ }^{81}$, rede internacional composta atualmente por mais 185 instituições de diversos países, cujo objetivo "consiste no empenho comum em ligar o passado ao presente e a memória à ação", o passado tem um grande poder "na construção de um futuro justo, humano e pacífico":

\begin{abstract}
Vimos como - em todas as partes do mundo - o passado tem lições para o nosso futuro. Ao analisar os fatores subjacentes que resultaram no Holocausto podemos encontrar maneiras de prevenir o genocídio hoje; caminhando na pele de gerações passadas de imigrantes, podemos entender melhor as lutas de imigração hoje; e para desvendar os mecanismos das ditaduras do passado, podemos lutar contra a repressão hoje. É por isso que nós trabalhamos não só para preservar a memória do que aconteceu antes, mas também para compreender o contexto em que estes eventos ocorreram e aplicar estas lições para as lutas de hoje pelos direitos humanos e da justiça social. Sítios de Consciência vão usar as lições da história para despertar a consciência das pessoas em todo o mundo, para que possam escolher as ações que promovam a justiça e a paz duradoura hoje. ${ }^{82}$
\end{abstract}

Por fim, a materialização da memória social propõe-se, ainda, às múltiplas funções: integração social; reconstrução de relações sociais; demarcação de uma nova identidade nacional e promoção do diálogo público construtivo, dentre outras. $^{83}$

Do mesmo modo, também a pauta dos espaços de memória é igualmente nova no cenário brasileiro, mais uma vez, tanto para o Estado quanto para a própria mobilização social. Algumas ações neste sentido vêm sendo implementadas, ora por parte do Estado ora por iniciativa de grupos sociais ${ }^{84}$. É

\footnotetext{
${ }^{79}$ Tradução livre do documentoLOZANO, Carlos; GUILLEROT, Julie. Concepto, fundamentos y opciones para emprender tareas de reparación colectiva y simbólica en Brasil.Bogotá: ICTJ, 2010. Disponível em: <https://www.ictj.org/sites/default/files/ICTJ-Brasil-Reparations-Options-2010Spanish.pdf >. Acesso em: 26 jul. 2015.

${ }^{81}$ Disponível em:<http://www.sitesofconscience.org/pt-br/membros/>. Acesso em: 13 jun. 2015.

${ }^{82}$ Disponível em:<http://www.sitesofconscience.org/pt-br/abordagem/>. Acesso em: 13 jun. 2015.

${ }^{83}$ NAIDU, op. cit., p. 12.

${ }^{84} \mathrm{Em}$ busca aleatória pela Rede Mundial de Computadores, é possível identificar uma diversidade de iniciativas brasileiras, embora não haja ainda uma sistematização desse trabalho. Alguns casos assim identificados: tombamento do antigo DOI/CODI da Rua Tutóia em São Paulo; construção do memorial do Cemitério de Vila Formosa, em São Paulo, no local correspondente ao ossário clandestino de desaparecidos políticos; tombamento do prédio do Batalhão de Polícia do Exército,
} 
possível notar que muitos grupos sociais, por todo o Brasil, têm reivindicado espaços que foram utilizados pela repressão para transformá-los em memoriais. ${ }^{85}$

E foi em consonância com estas bases e em meio a um cenário que expandia os debates em torno do enfrentamento desse passado e do uso de mecanismos de transição no Brasil, que um grupo de ex-presos políticos da cidade de São Paulo decidiu reivindicar o prédio do DEOPS/SP por volta do ano de 2007. Dentre eles, os quatro narradores que contribuem para a presente pesquisa.

A partir das quatro narrativas aqui analisadas, é que reconstituo parte desse processo de expansão de direitos, qual seja o processo de construção do Memorial da Resistência, desde a retomada do espaço pelo grupo de testemunhas do DEOPS, passando pela reconstituição das histórias de vida ali experimentadas, até a inauguração do espaço e sua troca de experiências com a comunidade nos dias atuais.

A decisão do grupo em se unir em torno da transformação do DEOPS em memorial parece então ter emergido de uma conjuntura de elementos positivos de promoção da memória, no ano de 2007:

O momento certo e as pessoas certas apareceram no início de 2007, quando se notou o despertar de uma nova mobilização em

no Rio de Janeiro;tombamento da antiga sede do Departamento de Ordem Política e Social (DOPS), em Belo Horizonte/MG; e construção do Memorial da Anistia Política do Brasil, embora de iniciativa do Estado brasileiro, por meio do Ministério da Justiça, em 2008, conta com o apoio e a participação ativa da Associação dos Amigos do Memorial da Anistia, dentre outros. A Secretaria de Direitos Humanos da Presidência da República, por meio do projeto "Lugares de Memória", identificou 222 espaços como estes. Disponível em: <http://cemdp.sdh.gov.br/modules/wfchannel/index.php?pagenum=14>. Acesso em 13 jun. 2015.

${ }^{85}$ São algumas dessas experiências: Memorial do Cemitério Ricardo de Albuquerque. Projeto inaugurado em 2011 que contou com a iniciativa da sociedade civil por meio da entidade Grupo Tortura Nunca Mais do Rio de Janeiro, formado também por sobreviventes e familiares de vítimas da ditadura, criou um espaço de homenagem aos quatorze mortos e desaparecidos políticos que teriam registro de enterro no local. Centro de Memória, Verdade e Justiça de Petrópolis. Iniciado pela sociedade civil local, por meio do Centro de Defesa dos Direitos Humanos - Grupo Ação Justiça e Paz de Petrópolis, no ano de 2012, o projeto pretende a transformação em memorial dos Centros Clandestino de Detenção - CCD conhecido como Casa da Morte de Petrópolis/RJ, local de onde desapareceram aproximadamente 19 militantes e de onde só uma presa sobreviveu. Memorial da Luta pela Justiça - Advogados Brasileiros contra a ditadura. Também na cidade de São Paulo, outro projeto pretende transformar o prédio da antiga Auditoria Militar em espaço de memória. Centro de Memória Viva da Resistência Latino-Americana - Na cidade de Porto Alegre-RS, o Comitê Carlos de Ré, uma iniciativa popular criada em 2011 em torno da pauta da justiça de transição, pleiteia a criação de um memorial no espaço que foi sede do DOPS naquela capital.

<http://www.torturanuncamais-rj.org.br/jornal/gtnm_74/memoria.html>; $\quad$ <http://www.cddh.org.br/>; ${ }^{85}$ Disponível em:<http://www.oabsp.org.br/noticias/2013/08/06/espera-inaugurar-o-memorial-da-lutapela-justica-no-proximo-ano-1/>;

$<$ https://comitedaverdadeportoalegre.wordpress.com/campanhas/>; 
defesa de uma verdadeira justiça de transição, que não havia ocorrido quando da transição do regime militar para o civil, e do resgate histórico dos valores democráticos contra a cultura da violência do Estado sobre o cidadão. Um novo governo, sensível ao assunto e com boa vontade e identificação para com a História, foi o dado que faltava para alcançarmos nosso primeiro objetivo. ${ }^{86}$

O reencontro do grupo se dá, segundo o narrador Ivan Akselrud Seixas, em torno do Fórum Permanente de Ex-Presos Políticos de São Paulo. Nas suas lembranças, foi entre os anos de 2007 e 2008, que o grupo se reuniu:

Em 2007, 2008, se não me engano, não lembro mais quando foi, eu entrei para o Fórum de Ex-Presos Políticos, eu e Politi, coincidentemente. O Politi eu não via há anos. Ele tinha se aposentado e voltou à militância. Funcionário de grande multinacional, ele estava no Brasil e começou a militar exatamente nessa área, e a gente se encontra exatamente no Fórum.

Nascido na cidade de Porto Alegre/RS, em 1954, o hoje jornalista Ivan Seixas é atual Vice-Presidente do Fórum. Sua entrevista foi realizada no prédio do Memorial, local de sua escolha, no dia 08 de novembro de 2014, em uma sala que ele mesmo fez questão de reservar para a ocasião. Preso aos 16 anos de idade, juntamente com pai, mãe e irmãs, pela atuação na resistência armada, Ivan conheceu diversas carceragens no Estado de São Paulo, dentre elas, o DEOPS. Seu pai foi assassinado nas primeiras horas após a prisão em razão das incessantes torturas, mesmo período em que Ivan ouvia os gritos da mãe e das irmãs sendo também torturadas no mesmo prédio do DOI-CODI. Passou quase 6 anos preso, dos quais muitos meses "sequestrado", sem registro oficial de prisão. ${ }^{87}$ Ivan esteve no DEOPS/SP em vários momentos, entre os anos de $1971 \mathrm{e}$ 1973, o que vai, mais tarde, ser fundamental na reconstituição do Memorial:

A participação de Ivan Seixas na formação do Memorial surge em sua fala carregada não pelo sentido das dores que certamente suas lembranças fazem

\footnotetext{
${ }^{86}$ SEIXAS, Ivan; POLITI, Maurice. Os elos que vinculam as vivências carcerárias com as perspectivas de comunicação museológica: olhar dos ex-presos politicos. In: ARAÚJO, Marcelo Mattos; BRUNO, Maria Cristina Oliveira. (Coord.) Memorial da Resistência de São Paulo. São Paulo: Pinacoteca do Estado, 2009. 201 p. 199-207.

${ }^{87}$ SEIXAS, Ivan. Depoimento de Ivan Seixas sob o título: Ivan Seixas - Preso e torturado pelo regime militar aos 16 anos. [10 abr. 2014]. Disponível em: <https://www.youtube.com/watch?v=4mt1FVvXdql>. Acesso em: 26 jul. 2015. Depoimento de IvanSeixas para SBT: Amor e Revolução - Depoimento \#5. [11 abr. 2011]. Disponível em: $<$ https://www.youtube.com/watch?v=w7IXQGOgFS4>. Acesso em:13 jun. 2015.
} 
aflorar, mas do sentido de solidariedade:

[...] eu sou ex-preso político, sou militante dos direitos humanos desde o dia que saí da cadeia. Passei a ser militante dos direitos humanos e, principalmente, da preservação da história do Brasil. Para a gente poder conhecer o país tem que conhecer a história. Eu faço parte também do grupo de preservação da memória política que tem um lema que nos guia que é "conhecer o passado para entender o presente e construir o futuro", pois só dessa forma você pode elucidar o que a gente tem no dia de hoje e principalmente fazer a construção de um futuro melhor. ${ }^{88}$

Para o narrador Maurice Politi, igualmente o reencontro do grupo se deu por meio das atividades do Fórum, do qual já foi membro da diretoria, sendo hoje um de seus associados. O narrador e eu nos encontramos no café do Memorial da Resistência em uma tarde de sexta-feira, dia 10 de janeiro de 2015. Com trânsito livre, parecia bem à vontade no espaço.

Imigrante egípcio, nascido em 1949, na cidade de Alexandria, Maurice Politi chegou ao Brasil aos oito anos de idade, juntamente com seus pais. Pela atuação junto à Ação Libertadora Nacional - ALN, o narrador foi preso no ano de 1970. Condenado inicialmente a 10 anos de reclusão, teve a pena posteriormente reduzida para 4 anos. Passou por vários espaços prisionais em São Paulo (DOICODI, DEOPS, Presídio Tiradentes, Casa de Detenção Carandiru e Penitenciária de Segurança Máxima em Presidente Venceslau/SP), sofrendo intensas subsequentes torturas. Participou de uma greve de fome coletiva por 33 dias, e teve seu processo de naturalização iniciado em 1969 revogado. Ao final, foi expulso do país, retornando somente após a Lei de Anistia, quando teve extinta sua punibilidade. Sua naturalização se deu somente em $1985 .{ }^{89} \mathrm{Sem}$ terminar os estudos universitários na Universidade de São Paulo, passou quase 25 anos longe do Brasil, entre o período de expulsão e o emprego em uma multinacional, retornando, com esposa e filhos, no ano de $2004 .{ }^{90}$

Passados mais de 25 anos fora do Brasil, entre exílio e trabalho, o narrador uniu-se ao Fórum quando retornou, momento em que a entidade ampliava sua

\footnotetext{
${ }^{88}$ Entrevista concedida em 08 nov.2014.

${ }^{89}$ BRASIL. Livro do votos da Comissão de Anistia: verdade e reparação aos perseguidos políticos do Brasil. Brasília: Ministério da Justiça; Florianópolis: Instituto Primeiro Plano, 2013. p.398-400

${ }^{90}$ Foram também consultadas outras fontes sobre a biografia de Maurice Politi: e POLITI, Maurice.

Depoimento para a História: A Resistência à Ditadura Militar no Paraná - Dh Paz. [08 fev. 2014]. Disponível em: <https://www.youtube.com/watch?v=r7rw40XWWww>. Acesso em: 26 jul. 2015.
} 
pauta de atuação para a promoção da memória política:

Quando eu volto, eu começo a reencontrar velhos companheiros, pessoas que justamente estavam começando essa luta pelo Memorial. E eu começo a me envolver no Fórum dos ex-presos Políticos de São Paulo, que é uma entidade que foi formada em $2001 .{ }^{91}$

$\mathrm{Na}$ fala da narradora Rosemary Nogueira, o reencontro do grupo se deu por volta dos anos 2005 e 2006, e sua atuação na retomada do espaço do Memorial também se deu em razão de sua participação no CONDEPE - Conselho Estadual de Defesa dos Direitos da Pessoa Humana. A narradora percebe esse processo enquanto uma integração de esforços por vários meios:

Eu era lá a presidente do CONDEPE e propus pelo CONDEPE, mandei um parecer que ele estava deturpado o prédio e ele deveria se transformar em um memorial. Eu prefiro a palavra memorial do que museu. Apareceram o Politi e o Ivan, foram lá no CONDEPE, o Ivan passou a integrar o Fórum de Ex-presos Políticos, e aí falando com eles, mais o Alípio e a Elza Lobo. Nós estávamos nos reencontrando naquele momento. Eu acho que isso era 2005, 2006, por aí, eu não sei muito bem. Aí a gente conversar para brigar pelo memorial. E aí tinha o CONDEPE, que era um Conselho de Estado brigando junto. Chamamos e assumimos essa luta. $E$ aí conseguimos. Foi transformado em memorial. ${ }^{92}$

Paulistana nascida em 1946, descendente de imigrantes italianos, Rose Nogueira, como se apresenta a jornalista, me recebeu em sua casa, em uma manhã de sexta-feira, dia 07 de novembro de 2014. Nossa conversa durou quase quatro horas, com pouco mais de uma hora e meia de gravação. A fala da narradora perpassa vários momentos de sua vida desde a infância, sempre correlacionando a história de vida de sua família com momentos históricos. O que, à primeira vista, poderia traduzir-se enquanto uma espécie de fuga ao tema proposto para a entrevista, se apontou no decorrer da conversa como uma verdadeira colcha de retalhos formada pela vasta bagagem de suas lembranças, conferindo à narradora a certeza "de que a história não é um evento ou vários eventos grudados, porém é um processo constante". ${ }^{3}$

Presa aos 23 anos, um mês após o nascimento de seu único filho, a

\footnotetext{
${ }^{91}$ Entrevista concedida em 10 jan. 2015.

92 Entrevista concedida em 07 nov. 2014.

${ }^{93}$ Entrevista concedida em 07 nov. 2014.
} 
caminhada que a levou até o Memorial foi, para a narradora, a continuidade de uma vida inteira em defesa dos direitos humanos:

\begin{abstract}
Eu sou dessa geração do pós-guerra, depois que o nazismo e o fascismo foram vencidos. E até hoje eu continuo anti-fascista. Sou socialista e gosto de ser. Lutei contra a ditadura desde os dezoito anos, que eu tinha em sessenta e quatro e acabei sendo presa aos vinte e três [...]. Desde o dia que eu saí da prisão eu decidi que eu lutaria pelos direitos humanos. E é o que eu faço até hoje e vou continuar fazendo onde eu estiver. ${ }^{94}$
\end{abstract}

Para a narradora Elza Ferreira Lobo, nascida no ano de 1937, na capital São Paulo, contando com 77 anos à data da entrevista, o reencontro do grupo para a formação do Memorial é também parte de uma constante "caminhada".

A entrevista com Elza se deu também em uma sala reservada no Memorial da Resistência. Sua fala é marcada pela preocupação constante em transmitir às novas gerações as informações sobre o que ocorreu durante a ditadura. Elza acredita que somente dessa forma se evitará o retorno de um período de exceção. Daí seu entendimento de que participar desse movimento é uma obrigação cidadã.

Formada em Jornalismo e Educação, Elza Lobo foi presa em 1969, permanecendo nesta condição por dois anos, entre vários espaços prisionais.

A narrativa de Elza permanece focada no trabalho conjunto realizado antes, durante e depois da prisão, no sentido de auxiliar, construir e superar. Passou muitos anos fora do país, em autoexílio na Argentina, Chile, Peru e França, retornando após a aprovação da Lei de Anistia de 1979. Com trajetória de vida sempre ligada à educação irrestrita e ao fim do analfabetismo, este é um ponto alto na percepção de Elza sobre a importância de participar do Memorial.

A experiência dos narradores no processo de construção do Memorial foi compartilhada com mais quatro ex-presos e, não raro nas suas falas, acabam citando essas outras participações sempre com a conotação e também atribuir aquela coletividade os trabalhos realizados. Ivan Seixas e Maurice Politi, por exemplo, fazem referência à liderança de Raphael Martinelli na decisão de retomar o prédio e de dedicarem-se à pauta mais abrangente da memória. ${ }^{95}$

\footnotetext{
94 Entrevista concedida em 07 nov. 2014.

95“"Raphael Martinelli, foi líder ferroviário e amigo pessoal de Jango. Perseguido e torturado pela ditadura, nunca deixou de lutar pela classe dos ferroviários e hoje é advogado e um tenaz militante
} 
Já com quase 90 anos de idade, o então Presidente da Federação Nacional dos Ferroviários quando eclodiu o golpe de 1964, Raphael Martinelli foi considerado um dos mais importantes líderes sindicais do Brasil. Segundo as lembranças de Ivan Seixas, por volta de 2007, Raphael chamou a atenção do grupo para a necessidade de reivindicar aquele espaço: "Quando o Martinelli fala: 'Olha, a gente tem que brigar para ter um Memorial lá onde era o DOPS, porque tá um horror aquilo lá', então nós viemos aqui conversar com o Secretário de Cultura". 96

Nas lembranças de Ivan Seixas, "o Memorial era uma luta antiga do Martinelli", que "lutou para transformar isso aqui no Memorial", "sempre brigando para ter esse Memorial." Há uma certa reverência na fala de Ivan Seixas ao citar Raphael, a quem chama carinhosamente de "velho" e por quem é chamado de "moleque".

As "provocações" de Raphael surgem também nas recordações do narrador Maurice Politi, como o grande estímulo daquele momento:

Mas tinha uns mais aguerridos, como o Martinelli. O Martinelli falou "Não, nós não podemos ficar só na reivindicação da reparação. Nós temos um problema político." E uma das nossas propostas no campo da educação, da memória, era a conversão do que era o Memorial da Liberdade. ${ }^{97}$

A decisão de envolver-se com a retomada do prédio parece não ter sido compartilhada por todos os membros do Fórum, já que alguns demonstravam um certo cansaço, como lembra o narrador Maurice Politi: "os mais velhos do Fórum, porque nós éramos considerados, eu e o Ivan, os mais jovens, eles diziam: Nós já conseguimos o que queríamos, agora queremos levar nossa vida tranquilamente'".

Segundo Politi, alguns também manifestaram discordância com a ideia de se envolver em um projeto de governo que não fosse de "esquerda". Nesse momento de suas falas, os narradores Maurice e Ivan evidenciam suas prioridades e o compromisso com a ampliação da agenda de promoção da memória, acima de

dos direitos humanos." Disponível em:<http://martinelliraphael.blogspot.com.br/.> Acesso em: 31 mai. 2015. Mais informações na recente biografia: BASTOS, Roberto Gicello. Estações de Ferro: Raphael Martinelli. São Paulo: Pinacoteca do Estado, 2015..

96 Entrevista concedida em 08 nov. 2014.

${ }^{97}$ Entrevista concedida em 09 jan. 2015. 
divergências partidárias. Havia naquela oportunidade, a possibilidade de levar para o Estado seus projetos políticos e, ainda, como traduz Dagnino, "suas crenças, interesses, concepções de mundo, e representações do que deve ser a vida em sociedade." 98

A memória social se instala de fato em uma arena de disputas políticas. $\mathrm{E}$ como política de Estado, lembrar e esquecer são resultados também de escolhas políticas. É o que ocorre, por exemplo, com monumentos ora erguidos, ora destruídos, conforme mudanças de governo, principalmente, autoritários. Nesta seara, o narrador Maurice defende que a reconstituição da memória política deve ser uma política acima de lados e partidos políticos: "tem gente que dizia "não vou me meter com governo tucano, isso não vai dar certo", e nós falamos: "não, não importa quem seja, o importante é que saia um projeto de um museu que é como a gente quer".

Havia, no entanto, um grupo de pelo menos oito pessoas, todas com experiência de passagem pelas carceragens do DEOPS, que estavam imbuídas do espírito defendido por Maurice Politi. Além dos quatro narradores, também estiveram envolvidos no processo pelo menos outros quatro ex-presos políticos, todos tendo passado, em algum momento, pelas carceragens do DEOPS/SP.

Além de Raphael Martinelli, também José Paiva, Alípio Freire e Frei Betto, somam-se ao grupo de "representantes dos ex-presos" políticos do DEOPS que trabalhou no processo de construção do Memorial da Resistência ${ }^{99}$.

O desejo dos narradores de reconstituir suas memórias sobre as experiências vividas no DEOPS e durante a ditadura, e que tomava corpo agora com o reencontro do grupo, é o desejo de recomposição de um passado comum que foi mantido em suas mentes mesmo com o distanciamento do grupo durante os anos que antecederam o reencontro. Isso se dá, segundo ideia defendida por Halbwachs, porque conservaram um sentimento de pertencimento ao grupo. ${ }^{100}$

$\mathrm{O}$ autor baseia-se na premissa de que uma lembrança depende menos da

\footnotetext{
${ }^{98}$ DAGNINO, 2004, p. 98.

${ }^{99}$ Seus nomes, igualmente confirmados pela equipe de profissionais do Memorial, surgem nas falas dos narradores todo momento. Nessas ocasiões, não raro os narradores tentam me convencer da importância de que todos sejam igualmente entrevistados para minha pesquisa, em uma clara defesa do espírito coletivo que os uniu em torno do projeto.

${ }^{100}$ HALBWACHS, 2003, p. 39.
} 
existência interna de "um vestígio do evento" que nos mantermos conectados em contato com um grupo, onde somos "capazes de nos identificar com ele e de confundir o nosso passado com o dele" (HALBWACHS, 2003, p. 33).

A capacidade de nos lembrarmos enquanto membros de um grupo está muito presente na fala da narradora Elza Lobo que, a todo instante, faz referência à primeira pessoa do plural, relacionando as ações sempre nas expressões "nós", "nossa" e "a gente". O sentido de coletividade é exaltado não só em referência ao trabalho realizado junto ao Memorial, mas também à resistência que se fez presente em face da ditadura.

No presente caso, o distanciamento do grupo, não minimizou o desejo em comum de restituir suas lembranças de momentos compartilhados, especialmente, àqueles nos tempos de DEOPS. Poderia se concluir, em respeito à linha defendida por Halbwachs, que os membros do grupo conservaram vivos "certos tesouros do passado e certos pressentimentos do futuro", a partir de "sua participação real, ativa e natural na existência de uma coletividade."101

As motivações que levaram o grupo a decidir pela reivindicação do prédio onde vivenciaram suas experiências compartilhadas de dor e resistência, surgem nas quatro falas de modo a apontar um leque bem vasto, não distinto, mas complementar, de sentidos, sempre vistos como um passo natural em suas vidas, permeadas pelo compromisso com os direitos humanos: dever de homenagem para com os que morreram na resistência política; dever de memória; e o dever de lançar luz à resistência política que se fez presente em face do arbítrio da ditadura; dentre outras questões.

Instigado a participar desta nova agenda, o narrador Maurice Politi viu sua atuação como um caminho natural que fatalmente deveria ser percorrido. Sua fala é carregada da consciência de um dever cívico de "politização", como um resultado possível da promoção da memória:

No meu caso, muito sinceramente, ao voltar ao DOPS e me envolver nisso não senti como um obstáculo que eu tinha que transpor. Me pareceu uma coisa natural que eu tinha que fazer. À medida que me integrei com o Fórum dos ex-presos para ajudar nesse processo de politização achei que era uma evolução natural

\footnotetext{
${ }^{101}$ Idem, 2003, p. 175.
} 
que a gente pleiteasse um lugar que já estava aberto. [... $]^{102}$

Outro sentimento que aflora das narrativas é a necessidade de prestar homenagem a todos que resistiram à repressão, aos que sobreviveram a ela e aos que pelas suas mãos morreram. Para Maurice, essa homenagem pode dar um sentido e significado a essas mortes: "teve gente que deu a vida por isso. Pessoalmente, eu achei aquilo como um dever meu. Então, voltar ao DOPS para mim era um dever: eu tenho que voltar, tenho que ajudar e não importa o que digam." 103

A decisão de reocupar o lugar, surge também como um compromisso em contar o que aconteceu ali para a juventude, no presente. Esta necessidade é uma das razões que levaram Ivan a decidir participar do processo: "nós tínhamos uma preocupação de memória [...] a gente quer transformar aquilo em um memorial que mostre o que aconteceu ali [...] mostrar para as pessoas que isso existiu." ${ }^{104}$

Essa possibilidade de lançar luz à resistência política que se fazia no cárcere a nas ruas, é também a motivação que surge na fala da narradora Rose, ao falar de sua participação no processo de formação do Memorial:

Eu gostei muito de participar desse processo, de pensar isso. Me fez um bem enorme, pessoalmente, mas principalmente porque eu estava com companheiros mostrando para a sociedade brasileira: "olha, existiu uma resistência brasileira". ${ }^{105}$

O envolvimento social é tido pela literatura internacional contemporânea, nos casos específicos em que os lugares de memória refletem as memórias de massivas e sistemáticas violações de direitos humanos, como um dos aspectos mais relevantes para que um memorial possa alcançar profícuos objetivos.

A mobilização dos ex-presos para a reformulação do espaço e sua participação nesse processo dá ao lugar características que vão além de mera exposição técnica de fontes de pesquisas. Tal entendimento é reflexo do compromisso assumido pelo grupo, quando aceita compartilhar, para além de suas

\footnotetext{
${ }^{102}$ Entrevista concedida em 10 jan. 2015.

${ }^{103}$ Entrevista concedida em 10 jan. 2015.

104 Entrevista concedida em 08 nov. 2014

${ }^{105}$ Entrevista concedida em 07 nov. 2014.
} 
vivências, dores e lamentos, também as responsabilidades pela tomada de decisões na concepção do novo espaço, convertendo-se em "atores-realizadores do Memorial". ${ }^{106}$

Ainda, a experiência na construção de memoriais tanto mais terá sucesso quanto mais contar com o envolvimento social, especialmente por parte dos que vivenciaram diretamente as experiências que se quer contar ${ }^{107}$. A iniciativa e a participação social tem sido destaque nas execuções práticas da memorialização, como destaca Patricia Tappatá de Valdez:

A memória conta com uma variedade de ferramentas e canais para ser elaborada e transmitida, e isso lhe permite sobrepor-se aos esforços por torná-la hegemônica. Assim, os monumentos, placas, ícones ou marcas em espaços, ou a nominação de espaços públicos em recordação às pessoas ou a acontecimentos, são habitualmente iniciadas ou impulsionadas por grupos reunidos em torno de motivações comuns: sua posição de familiares, a defesa de direitos humanos, posições políticas ou militância à época que se rememora. ${ }^{108}$

A participação social no processo de ressignificação de um espaço que foi palco de sistemáticas violações de direitos humanos em espaço de memória, aponta, ainda, para uma dimensão de ação coletiva capaz de transformar a relação do indivíduo com seu destino político, de seus concidadãos e da própria comunidade. À medida que esse processo conta com a participação social, por meio da organização, ação e reivindicação para transformar a realidade, convertese em pleno exercício da nova cidadania.

Decididos a retomar o prédio, e a participar efetivamente de sua transformação em espaço vivo de memória, o grupo segue ao encontro do encorajamento possível para "a prática de responsabilidade coletiva da cidadania", defendido por Jelin, como necessário a romper com a ideia de que a população não reivindica seus direitos. Desta forma, vai buscar justamente afetar de modo

\footnotetext{
${ }^{106}$ VARINE-BOHAN, Hugues. Os princípios da Sociomuseologia a serviço da preservação da memoria da resistência política: uma reflexão sobre as metodologias aplicadas ao projeto. In: ARAÚJO, Marcelo Mattos; BRUNO, Maria Cristina Oliveira. (Coord.) Memorial da Resistência de São Paulo. São Paulo: Pinacoteca do Estado, 2009. p. 209- 221.

${ }^{107}$ NAIDU, op.cit., p. 12.

${ }^{108}$ VALDEZ, Patricia Tappatá de. Cuando nada es suficiente. In: TOSI, Giuseppe et al (Orgs.) Justiça de transição: direito à justiça, memória e à verdade. João Pessoa: Editora da UFPB, 2014. p. 36-37.
} 
radical o relacionamento entre coletividade e Estado por meio do exercício de seus direitos de cidadania na vida prática ${ }^{109}$, trazendo para o Memorial a dimensão de ação coletiva.

Ao longo da história de desenvolvimento da cidadania, tão diverso, complexo e, não linear em cada país, algumas percepções se solidificam com mais clareza na aproximação com uma cidadania plena. Se, de um lado, necessita a divisão das riquezas e o compartilhamento de bens e serviços, também depende "da luta e das reivindicações" sociais para a melhoria de vida da coletividade e, ao final, "uma sociedade mais justa, igualitária, com menos diferenças sociais. ${ }^{110 " ~ O s ~ p r o j e t o s ~ d e ~}$ participação social, ainda que focados em agendas que pareçam à primeira vista, voltadas à núcleos restritos de direito, tem sempre a vocação de atuar na expansão de um rol infinito de direitos.

Nesta tarefa, a anunciada nova cidadania, defendida por Evelina Dagnino, segue como balizadora de um projeto verdadeiramente democratizante, tendo como base o nexo entre cultura e política, incorporando características da sociedade contemporânea como:

Papel das subjetividades, a emergência de sujeitos sociais de novo tipo e de direitos de novo tipo, a ampliação do espaço da política. Essa é uma estratégia que reconhece e enfatiza o caráter intrínseco e constitutivo da transformação cultural para a construção democrática. ${ }^{111}$

A partir destas bases, a nova cidadania compõem-se dos seguintes elementos constitutivos:

A nova cidadania assume uma redefinição da ideia de direitos, cujo ponto de partida é a concepção de um direito a ter direitos. Essa concepção não se limita a provisões de direitos legais, ao acesso a direitos definidos previamente ou à efetiva implementação de direitos formais abstratos. Ela inclui a invenção/criação de novos direitos, que surgem de lutas específicas e de suas práticas concretas. [...] A nova cidadania requer - é inclusive pensada como consistindo nesse processo - a constituição de sujeitos sociais ativos (agentes políticos), definindo o que consideram ser seus direitos e lutando para seu reconhecimento enquanto tais. [...]A nova cidadania transcende uma referência central do conceito

\footnotetext{
${ }^{109}$ JELIN, Elizabeth. p. 165

${ }^{110}$ PINSKY, Jaime. PINSKY, Carla Bassanezi , (orgs.). História da Cidadania. 6 ed., São Paulo: Contexto, 2014. p. 13.

${ }^{111}$ DAGNINO, Evelina. Os movimentos sociais e a emergência de uma nova noção de cidadania. Anos 90. In: (org.). Política e sociedade no Brasil. Ed. Brasiliense, 1994, p. 103-115.
} 
liberal: a reivindicação ao acesso, inclusão, participação e pertencimento a um sistema político já dado. O que está em jogo, de fato, é o direito de participar na própria definição desse sistema, para definir de que queremos ser membros, isto é, a invenção de uma nova sociedade. ${ }^{112}$

Ao realizar uma leitura da participação dos ex-presos políticos a partir destas bases e componentes, é possível identificar nesta atuação o compromisso com um projeto verdadeiramente democratizante, pela presença de pelo menos três aspectos, que serão aprofundados mais à diante: primeiro, buscam justamente trabalhar suas histórias de vida, ou seja, suas subjetividades, em prol da construção de uma memória social da ditadura. Em segundo lugar, ao projetarem suas vozes, lançam luzes sobre um grupo de sujeitos sociais cuja "história oficial" tratou de tentar invisibilizar, ocupando agora o seu espaço como novo sujeito de novos direitos (direito à verdade; à memória; à resistir; à reparação; à justiça; ao luto; à informação pública; e etc.). Por fim, se dirigirem aos jovens propondo reflexões sobre práticas sociais e culturais atuais em diálogo com as experiências do passado, dispondo-se a promover mudanças de caráter político, social e cultural. Eis o complexo e profícuo envolvimento que se inicia com a retomada do espaço.

1.2 "NÓS FINCAMOS A BANDEIRA DA DEMOCRACIA"113: REIVINDICAÇÃO E RETOMADA DEOPS/SP PARA A CONSTRUÇÃO DO MEMORIAL DA RESISTÊNCIA

Ecléa Bosi ensina que "uma história de vida não foi feita para ser arquivada ou guardada numa gaveta como coisa, mas existe para transformar a cidade onde ela floresceu". ${ }^{114}$ Nesse sentido, transformar o espaço antes ocupado por uma das polícias políticas mais perversas da ditadura, se propõe a ressignificar essas violações e chamar atenção para as resistências políticas que se fizeram presentes

\footnotetext{
${ }^{112}$ DAGNINO, Evelina. Sociedade civil, participação e cidadania: de que estamos falando? In: MATO, Daniel (coord.), Políticas de cidadania e sociedade civil em tempos de globalização. Caracas: FACES, Universidade Central de Venezuela, 2004. p. 95-110.

${ }_{113}^{13}$ Fala de Ivan Seixas na entrevista concedida em 08 nov. 2014.

${ }^{114} \mathrm{BOSI}$, Ecléa. O tempo vivo da memória. São Paulo: Ateliê editorial, 2003. p. 69.
} 
no cárcere e nas ruas.

O espaço objeto de reivindicação do grupo de ex-presos e que ocupa um suntuoso prédio de tijolinhos vermelhos no Largo General Osório, n 66, na região central da cidade de São Paulo, é rico de significados para o grupo e, também, para a própria memória da cidade. Alguns memoriais podem até ser construídos do "zero", em espaços neutros e imparciais. No entanto, quando se opta pela transformação do próprio espaço, o qual abrigou as experiências de vida que se quer narrar, o memorial será preenchido de significados ímpares, e de sentidos que verdadeiramente reconstituem e preservam as histórias ali vivenciadas. A ocupação e a transformação são opções de tal maneira carregadas de sentido que vão, desde a concepção do memorial, corroborar com seu significado e objetivos.

O objeto da reivindicação do grupo encontra-se inserido em um contexto geográfico e social permeado pelas complexidades das grandes metrópoles brasileiras, quais sejam, as várias faces da gritante desigualdade social.

À sua volta está o prédio sede da Pinacoteca de São Paulo ${ }^{115}$, espaço que recebe grandes exposições de artistas internacionais e o Museu da Língua Portuguesa. Nas proximidades está a Estação da Luz, mais um ponto de referência para a história da cidade, enquanto estação férrea que recebia os imigrantes e forma hoje um complexo arquitetônico tombado. Nessa mesma região encontra-se o que é considerado "o maior centro de comércio da América Latina e um dos principais pontos turísticos da capital."116

De um lado, o Memorial é vizinho da Sala São Paulo, um complexo cultural que abriga espetáculos de orquestras sinfônicas e óperas de reconhecimento mundial. De outro, tem a sua frente diversos prédios ocupados pelos movimentos de resistência por moradia adequada e uma grande população morando nas ruas de sua redondeza. Não raro, a região é um cenário de conflitos policiais, tanto com

\footnotetext{
115“'A Pinacoteca do Estado é um museu de artes visuais, com ênfase na produção brasileira do século XIX até a contemporaneidade, pertencente à Secretaria de Estado da Cultura. Fundada em 1905 pelo Governo do Estado de São Paulo, é o museu de arte mais antigo da cidade. Está instalada no antigo edifício do Liceu de Artes e Ofícios, projetado no final do século XIX pelo escritório do arquiteto Ramos de Azevedo, que sofreu uma ampla reforma com projeto do arquiteto Paulo Mendes da Rocha, no final da década de 1990." Disponível em: http://www.pinacoteca.org.br/pinacotecapt/default.aspx?mn=534\&c=1004\&s=0\&friendly=institucional\&video=false.

116 Disponível em: <http://www.cidadedesaopaulo.com/sp/br/o-que-visitar/atrativos/pontosturisticos/4406-rua-25-de-marco>. Acesso em: 28 jun. 2015.
} 
os ocupantes dos imóveis abandonados, quanto com a população que vive nas ruas. Esse efervescente contexto social, marcado pelas desigualdades dos centros urbanos brasileiros, surge nas palavras de Rose, em um momento em que narra com detalhes o que sabe sobre a história daquela região:

[...] é onde hoje chama Sala São Paulo, que é da Secretaria de Cultura. É onde se tem muitos concertos e escola de música. E do lado de fora, olha a nossa sociedade, é chamado de cracolândia, a praça da frente, que já foi uma estação rodoviária e foi demolida. Então, São Paulo tem essa característica de transformação, de boniteza, de beleza pela grandiosidade e de destruição ao mesmo tempo. É o convívio pelas duas coisas. ${ }^{117}$

A retomada do espaço e sua transformação em espaço vivo de memória, como acredita o narrador Ivan, possibilita que o próprio local ganhe novo significado, inclusive para a comunidade na qual se insere. Um espaço vazio de significados é também vazio para a sociedade que o circunda, convertendo-se no que Bauman denomina os "lugares vazios" de significado, onde a percepção que se tem deles é de uma sobra na projeção da cidade, uma quase invisibilidade e inexistência na sua cartografia. Sobre a exclusão desses espaços no imaginário social, Bauman destaca que neles "não se entra e onde se sentiria perdido e vulnerável, surpreendido e um tanto atemorizado pela presença de humanos". ${ }^{118}$

À medida que o prédio é ocupado e transformado, em espaço de homenagem e espaço vivo de reflexão política, essa ocupação configura-se como "salvamento" desse espaço no mapa dos lugares vazios de significado. Ainda, ao passo que visa recuperar de volta para a sociedade um espaço que estava antes sendo utilizado para a prática de violações pelo próprio Estado, este processo se vê investido de legítima retomada social, como destaca com orgulho o narrador Ivan:

Você sabe aquela foto dos soldados que vão conquistando o terreno e eles vão lá e cravam a bandeira? É isso que eu sinto. Eu sinto que como a gente fez a transformação nesse Memorial, nós cravamos a bandeira. Isso aqui é nosso. Sempre foi da sociedade. Isso nunca foi da ditadura, ela usurpou da gente, ela usurpou. Isso aqui era um armazém de trens. Eles usurparam e deram uma destinação canalha que é torturar, prender e tudo mais. Nós recuperamos isso para a sociedade, nós retomamos e fincamos a

${ }^{117}$ Entrevista concedida em 07 nov. 2014.

${ }^{118}$ BAUMAN, Zygmunt. Modernidade Líquida. Rio de Janeiro: Jorge Zahar Ed., 2001. p. 199-200. 
bandeira da democracia. ${ }^{119}$

O processo de retomada do prédio foi antecedido por uma série de ocupações e, até mesmo, por alguns momentos de abandono do local. Tais eventos reforçam a ideia de que a memória social é uma arena que põe em disputa o que será recordado e, em consequência, o que será esquecido. Mesmo quando não havia reivindicação social para fazer uso do local, o espaço estava lá, cumprindo uma função, ainda que fosse a função do "não recordar". Com a reivindicação dos ex-presos políticos, o que se quer é, também, dentre tantos outros aspectos, reconstruir e ressignificar essa função.

Sob a gestão da Pinacoteca do Estado de São Paulo desde 2004, quando o grupo decidiu que lutaria pelo espaço onde compartilharam suas experiências havia duas propostas do Estado de São Paulo em andamento para a ocupação do local. A primeira, para sediar a Escola Superior ou Universidade Livre de Música e a segunda para ocupação de uma escola de teatro.

No ano de 1999, quando o imóvel foi tombado pelo Conselho de Defesa do Patrimônio Histórico, Artístico, Arqueológico e Turístico do Estado de São Paulo (CONDEPHAAT), foram realizados dois eventos culturais no espaço, em referência à ditadura, em virtude dos vinte anos de comemoração da Lei de Anistia de 1979. ${ }^{120}$

\footnotetext{
${ }^{119}$ Esta mesma ideia foi, no ano de 2014, defendida pela Comissão Nacional da Verdade do Brasil. Ao analisar o uso de diversas instalações públicas pelas Forças Armadas durante a ditadura, no sentido de cumprir seus objetivos no esclarecimento das circunstâncias de graves violações de direitos humanos, e tendo apurado um pequeno universo de 24 casos específicos em que houve a prática de violações, o órgão questionou os comandos do Exército, Marinha e Aeronáutica sobre a ocorrência de torturas e mortes em seus estabelecimentos. Mesmo oficialmente reconhecidas pelas comissões de investigação criadas pelo Brasil que precederam a criação da CNV - Comissão Especial sobre Mortos e Desaparecidos Políticos (1995) e Comissão de Anistia (2002), as violações de direitos humanos praticadas em delegacias e presídios destacados pela CNV foram, mais uma vez, negadas pelas Forças Armadas. Mais informações no documento publicado pela CNV em, intitulado "Quadro parcial das instalações administrativamente afetadas ou que estiveram administrativamente afetadas às forças armadas e que foram utilizadas para perpetração de graves violações de direitos humanos." Disponivel em: <http://www.cnv.gov.br/images/pdf/relatorio_versao_final18-02.pdf>. Acesso em: 24 mar. 2015.

${ }^{120}$ Segundo MENEZES, Caroline Grassi Franco; e NEVES, Kátia Felipini, 2009, p. 37: A exposição "Anistia 20 anos" trazia a público o contexto político-social durante a ditadura e a luta pela anistia política, por meio de painéis, fotografias, cartazes e documentos originais da época. O espetáculo teatral "Lembrar é resistir", por sua vez, foi encenado dentro da carceragem do DEOPS, antes da reforma do espaço, com "representação dramática do passado de repressão vivido por milhares de brasileiros presos e torturados pelo regime". Foi de tamanho sucesso que permaneceu em cartaz de setembro de 1999 até o final de 2000, sendo, posteriormente, encenada na cidade do Rio de
} 
No ano de 2002, as obras de revitalização foram concluídas e o prédio foi entregue à Secretaria de Cultura com a proposta de instalação de dois museus no local. O primeiro seria o Museu do Imaginário do Povo Brasileiro, ${ }^{121}$ voltado à preservação e difusão das tradições populares. Criado pelo governador do Estado, com a finalidade de coletar, difundir, preservar e estimular a "produção das artes e da cultura popular brasileira", acabou por não ter sua implantação concretizada.

O segundo espaço, voltado à temática da ditadura, recebeu o nome de Museu do Cárcere, sendo criado em janeiro de 2002, em atenção à "importância da preservação de símbolos da resistência à repressão e da difusão dos ideais de liberdade". Com a proposta de ser instalado nas dependências do DEOPS, trazia como objetivo "estimular o exercício da cidadania e seus valores democráticos, por meio de mostras, exposições e outras manifestações artísticas e culturais". ${ }^{122}$

Seis meses mais tarde, em julho daquele mesmo ano, o governador do Estado de São Paulo revogou a criação do Museu do Cárcere, criando, em seu lugar, o Memorial da Liberdade, para ser instalado na "área prisional do prédio do antigo DOPS". No decreto, são citadas como base para sua criação: a promoção e facilitação da educação e do conhecimento sobre os direitos do homem e das liberdades fundamentais; investigação e estudos para reforçar a compreensão, a tolerância e a paz; preservação e difusão dos ideais de liberdade; promoção de ações educativas que consolidem os princípios democráticos; e a manutenção dos valores democráticos. ${ }^{123}$ Nesses termos, o Memorial da Liberdade foi inaugurado em 4 de julho de 2002. ${ }^{124}$

Os fundamentos e a concepção do Memorial da Liberdade, no entanto, pareciam não corresponder aos anseios de um grupo de ex-presos políticos de São

\footnotetext{
Janeiro, nas dependências da sede do DOPS daquele Estado.

${ }^{121}$ Criado pelo decreto $n^{\circ} 46.507$ de 21 de janeiro de 2002.

${ }^{122}$ Decreto $n^{\circ} 46.508$, de 21 de janeiro de 2002.

${ }^{123}$ Decreto $n^{\circ} 46.900$, de 5 de julho de 2002. Acesso em: 17 mar. 2015.

124 O espaço contou, naquele momento, com três instalações artísticas: "Intolerância", inaugurada ainda no Museu do Imaginário do Povo Brasileiro, do artista plástico Siron Franco, composta de "dez esculturas e 880 figuras humanas executadas com roupas e sapatos preenchidos com espuma"; mostra "Cotidiano Vigiado - Repressão, Resistência e Liberdade nos Arquivos do DOPS 1924-1983", com fotos e documentos originários do acervo do DEOPS/SP; e a exposição "Cidadania - 200 anos da Declaração Universal dos Direitos do Homem do Cidadão". Ainda como Memorial da Liberdade, o espaço abrigou, em 2005, a exposição "Caderno de Notas - Vlado, 30 anos", organizada pelo sindicato dos Jornalistas no Estado de São Paulo, reunindo obras de 45 artistas, marcou três décadas do assassinato do jornalista Vladimir Herzog.
} 
Paulo. A descaracterização física e o conteúdo expositivo incomodaram os narradores por várias questões: ausência de representação de suas experiências de vida; nova face de autoritarismo, com ares de "limpeza", corroborando com o alienação, negação e o abandono por parte do Estado, são alguns exemplos.

A indignação em face do "embelezamento" do espaço, a ausência de referências sobre as histórias vivenciadas entre aquelas grades e paredes, a demolição das celas, as fotos de pontos turísticos do país e até a limpeza do Memorial da Liberdade incomodavam de fato o grupo de narradores.

O prédio guardava pouco de sua estrutura original interna preservada ao longo das décadas, como explicam Ivan e Maurice:

A reforma promovida, pelos governantes, fez desaparecer as quatro
celas solitárias, as duas coletivas e a carceragem do presídio do
DEOPS/SP. Nas celas que sobreviveram a essa reforma
desapareceram os diminutos banheiros e as inscrições feitas pelos
presos nas paredes e portas, ao longo de toda a história do local. ${ }^{125}$

O espaço apresentava naquele momento muito mais a simbologia da riqueza e do poder econômico de uma época, do que a representação da repressão e da resistência políticas, não retratando as experiências vivenciadas no espaço nos tempos da ditadura. Seu "embelezando", soou, para os narradores, como "uma ação autoritária", carregada de interesse em descaracterizar as mazelas ali vividas, como se ao Estado Democrático não fosse do interesse conhecê-las. ${ }^{127}$ Aqui, fica evidenciada a disputa política na qual se insere a memória social, nas escolhas daquilo que será lembrado ou esquecido nos espaços sociais, como visto em Michael Pollak. ${ }^{128}$

A omissão das características originárias do DEOPS no então Memorial da Liberdade representou, naquele momento, para o narrador Maurice, o abandono: "e a gente vinha aqui e era uma tristeza. Vinha cinquenta pessoas por mês. Não tinha nada escrito. Das quatro celas algumas tinham uns cartazes, mas não tinha nenhuma explicação e o lugar tinha sido abandonado." 129

Sem nunca mais ter voltado ao local desde o fim de sua prisão, a narradora

\footnotetext{
${ }^{125}$ SEIXAS; POLITI; 2009,p. 200.

${ }^{127}$ Ibidem,2009,p. 200.

${ }^{128}$ Ver POLLACK, Michael. "Memória, esquecimento, silêncio". In: Revista Estudos Históricos, v.2, Rio de Janeiro, 1989.

${ }_{129}$ Entrevista concedida em 10 jan. 2015.
} 
Rose Nogueira é confrontada com estes mesmos sentimentos, quando retorna ao local para uma entrevista, ainda por volta de 2002:

Lá no DOPS era um prédio lindíssimo, limpíssimo. No tempo que fiquei lá era uma imundície, era um horror, era aquela coisa horrorosa. Eles demoliram uma parte, nas celas que foram de presos políticos, no caso da ditadura. [...] Tinha fotos da fundação de Brasília, por exemplo, foto do Palácio do Planalto, foto de Copacabana, do Cristo Redentor, de cartões postais brasileiros. E eu fiquei muito indignada com aquilo e falei: "Meus Deus, por aqui já passou Monteiro Lobato, e passamos nós também. Aqui passaram todos os combatentes pela liberdade de São Paulo"130

A discordância com a forma como o espaço era apresentado à sociedade surge também na fala da narradora Elza: "Tinha começado antes quando foi colocado como Memorial da Liberdade e a gente não concordava com aquilo, porque não era Memorial da Liberdade. O que aconteceu foi realmente o Memorial da Resistência." Elza também descreve a falta de referência às experiências vivenciadas naquele espaço:

Não fazia referência ao que era antes. Ele ficou muito tempo fechado. O primeiro grupo que se envolveu foi só numa a representação teatral que foi muito importante, com a atriz que tinha ficado presa aqui. $O$ fato de representar trouxe muito o lado esse resgate, de estar abrindo o espaço de um lugar onde as pessoas tiveram um outro tipo de vivência. As pessoas tiveram outro tipo de vivencia. ${ }^{131}$

As ideias de abandono, desfiguração e distanciamento com as experiências de repressão e resistência políticas confrontam o compromisso com memória e educação políticas, aspectos que formavam o núcleo de objetivos dos narradores no interesse de construir um memorial. Desde o início, esses pontos também foram de preocupação dos agentes públicos, vistos, inclusive, como uma questão sistêmica da própria museologia e identificada por eles também no Memorial da Liberdade:

A ideia de abandono, a realidade dos vestígios fugazes, a constatação relativa à descaracterização dos monumentos, a convivência cotidiana com ruínas tem sido, de forma reiterada, um dos cenários em que os processos museológicos buscam apoiar as

\footnotetext{
${ }^{130}$ Entrevista concedida em 07 nov. 2014.
}

131 Entrevista concedida em 08 nov. 2014. 
suas bases fundadoras. [...] ${ }^{132}$ Partimos, portanto, da consideração de que esse abandonado conjunto prisional representava um território de extrema importância para a interpretação sobre a relevância da resistência ali construída e vivenciada pelos presos políticos, a qual teve enorme contribuição para a redemocratização do país. ${ }^{133}$

A descaracterização percebida no cenário que abrigou o DEOPS/SP, realizada por meio de demolições, retirada de móveis, substituição de materiais originários, e até mesmo simples pinturas de parede, é apontada pelas especialistas que trabalharam em sua reconstituição como uma forma de varrer do presente as evidências do passado político.

Quase sem luz, ocultam os seus antigos desígnios deixando de mostrar o grotesco e a exclusão premeditada pelo Estado. [...] Lapidadas pelo restauro, são fragmentos esgarçados da memória, memória perversa que guarda sussurros, gemidos. Nos andares superiores, desapareceram as salas majestosas e o mobiliário talhado por mestres do ofício para servir às autoridades da ordem. ${ }^{134}$

Essa descaracterização ganha também contornos de "despiste histórico". Com o subterfúgio de homenagem, mas só na aparência, frustra a identificação do que de fato teria acontecido no lugar e de como se dava, de fato, o cotidiano dos presos e de seus repressores, sendo "algo bonito, mas sem significado histórico."135

Outras implicâncias, ainda, advêm com a descaracterização do espaço, como a destituição de sua identidade:

Restaurado, o prédio mantém hoje seu partido arquitetônico com novas funções muito mais direcionadas à cultura do que à memória política. De forma muito tímida e surda, o Memorial da Liberdade rende suas homenagens aos presos mortos e desaparecidos da Ditadura Militar. [...] Enfim, o local carece de uma identidade política, apesar da preservação das celas que foram maquiadas para manter as ideias fora do lugar. ${ }^{136}$

\footnotetext{
${ }^{132}$ ARAÚJO, Marcelo Mattos et al. A implantação do programa museológico. In: ARAÚJO, Marcelo Mattos; BRUNO, Maria Cristina Oliveira (Coord.).Memorial da Resistência de São Paulo. São Paulo: Pinacoteca do Estado, 2009. 53 p. 53-97.

${ }^{133}$ ARAÚJO, 2009. op. cit.,55

${ }^{134}$ BRUNO, Maria Cristina Oliveira; CARNEIRO, Maria Luiza Tucci; AIDAR, Gabriela. Projeto Museológico de Ocupação. A implantação do programa museológico. In: ARAÚJO, Marcelo Mattos; BRUNO, Maria Cristina Oliveira (Coord.). Memorial da Resistência de São Paulo. São Paulo: Pinacoteca do Estado, 2009.p. 39-49.

${ }^{135}$ SEIXAS; POLITI. op. cit., p. 200.

${ }^{136}$ BRUNO, 2009. op. cit., p. 40-41.
} 
Por essas razões aqui apontadas, recapitular os atributos originais do lugar cujas lembranças se quer reconstituir é, portanto, uma necessidade premente quando se deseja trabalhar a memória social, a partir da devolução da "identidade social e política" ao prédio:

Atentos aos processos de higienização da memória, não devemos
perder de vista as múltiplas funções atribuídas a este prédio desde
o início do século XX até os dias atuais. Não devemos ser
coniventes com os restauros arquitetônicos implementados por
políticas públicas interessadas em passar um verniz sobre o
passado político do Brasil República ou das duas ditaduras, a de
Getúlio Vargas a Militar. ${ }^{137}$

O sentimento despertado no grupo, de indignação com a reforma que descaracterizou o lugar, reforça a ligação do espaço com as memórias das experiências vividas como sendo algo muito marcante, quando não determinante, para a reconstituição da memória social. Este processo ocorre com frequência, segundo Bosi, nas experiências de convívio no cárcere, nas interações dos movimentos sociais e na realização de marchas e assembleias, situações em que o espaço será importante referencial na reconstituição da memória social. ${ }^{138}$

A partir de referências de pessoas, acontecimentos e também lugares, por meio dos quais captamos experiências vividas e herdadas, é que a memória social poderá ser forjada, como defende Michael Pollak. ${ }^{139}$

Ainda, segundo Maurice Halbwachs, no processo de formação social da memória, "não há memória coletiva que não aconteça em um contexto espacial." ${ }^{140}$ Segundo o autor, é revisitando o espaço pelo qual passamos muitas vezes, que nossa imaginação ou pensamento é capaz de reconstruir e de lembrar. Considerando, por exemplo, os laços de parentesco, grupos econômicos e religiosos, que a princípio independeriam do convívio espacial, o autor destaca que, em diversos momentos, o espaço compartilhado por esses grupos receberá inevitavelmente suas marcas e vice-versa, sendo inviável tratar suas identidades de modo destacado desse referencial físico.

\footnotetext{
${ }^{137}$ BRUNO, 2009. op. cit., $39-40$.

${ }^{138}$ BOSI, 2003. op. cit., p. 27-28.

139 POLLAK, 1989, op. cit., p. 9.

${ }^{140}$ HALBWACHS, 2003. op. cit.,p.170.
} 
Uma vez que decidem por reivindicar o lugar, este processo, implica fatalmente, retornar ao local e reencontra-se com suas representatividades nas suas recordações. Nesse percurso, serão suscitadas, fatalmente, diversas lembranças. Por se tratar de exercício que conclama experiências compartilhadas de momentos de dor, sofrimento e perdas, é de se esperar que estes sentidos surjam nas suas recordações. Cada narrador vai trabalhar as lembranças desse momento de reencontros de uma maneira muito peculiar, mas que, sem dúvida iniciam-se pelas dores.

As experiências com a dor das torturas no DEOPS surgem nas memórias da narradora Elza: "você saia da violência da tortura, a mais terrível, no DOI-CODI, e aí você vinha para esse prédio aqui que também era um espaço de tortura, uma situação muito pesada."141

A morte de um companheiro de cela após sessões de tortura aflora nas lembranças do narrador Maurice "teve um que, por caso, eu e o Martinelli, estávamos na cela, e ele morreu. Ele tinha trinta e poucos anos, bateram tanto nele e quando voltou para a cela não parava de sair sangue, sangue, sangue". ${ }^{142}$

Maurice faz ainda uma relação entre essa experiência e a decisão de participar do processo de construção do Memorial: "e a gente viu que ele estava morrendo. Então quando eu lembro disso, eu falo 'a sua morte não foi em vão', as pessoas aprendem com a morte dele o que é a democracia".

Assim também não deixa de lembrar Ivan Seixas: "as pessoas morreram aqui. Morreram torturadas".

Nas lembranças do narrador Maurice, no entanto, pisar novamente o prédio do DEOPS foi menos doloroso que pisar em outros locais por onde passou naqueles tempos.

Voltar ao prédio, para a narradora Rose foi bem contraditório, sendo "muito ruim e muito bom ao mesmo tempo e muito terapêutico." Ela recorda das dificuldades que superou para se envolver no projeto:

Era difícil, mas eu já vinha (no Memorial), já tinha encontros, a gente já vinha trabalhando com isso. Não foi gostoso. No livro foi a

\footnotetext{
${ }^{141}$ Entrevista concedida em 08 nov. 2014.

142 Entrevista concedida em 10 jan. 2015.
} 
primeira vez que eu falei de mim. Eu falei com ela (Kátia Filipini, gestora do Memorial) que é preciso falar das nossas coisas. Um prédio sozinho sem seres humanos, mesmo depois que a gente for embora a gente vai estar lá. E não foi só a nossa geração. Teve muita coisa. ${ }^{143}$

Ocorre que, de modo bem marcante, todos os quatro narradores, no momento em que abordam as experiências vividas no DEOPS, atribuem ao tempo vivido naquelas carceragens também a recordação de um tempo de "descanso", em uma época de suas vidas marcada por sistemáticas prisões, suplícios, perdas e incertezas. Esse "descanso" surge representado pelas recordações de solidariedade e companheirismo com os quais o grupo identifica o período de vida naquele espaço.

Para Maurice Politi, identificar o local onde esteve preso com esse sentimento contraditório de conforto foi de fato uma surpresa. O sentido que mais Ihe foi percebido não foi o ligado às violências vivenciadas, mas o da solidariedade que se manifestava no convívio do cárcere entre os presos:

Achei que voltar aqui para fazer isso me trazia lembranças, mas para ser sincero, a lembrança que eu tenho do DOPS, entre uma ou outra seção mais violenta, eu não fui torturado aqui no DOPS, eu fui torturado na OBan. Aqui, ao contrário, aqui foi onde eu senti mais solidariedade. Aqui eu penso mais na solidariedade que aqui se manifestou. [...] Aqui é mais a ideia de companheirismo.

Superadas essas fases e certos da iniciativa, o grupo atende agora o chamado do Estado para compor o processo formação do Memorial.

\section{3"A HISTÓRIA É DE TODOS NÓS" ${ }^{144: ~ C O N C E P C ̧ A ̃ O ~ E ~ C O N S T R U C ̧ A ̃ O ~ D O ~}$ MEMORIAL DA RESISTÊNCIA}

Com um amplo cenário aberto às mais variadas pautas da justiça de transição, o reencontro do grupo e a decisão pela reivindicação de prédio do DEOPS/SP, o grupo vai, finalmente, ao encontro do Estado de São Paulo, seu curador. A partir deste encontro será firmada uma parceria entre o grupo de ex-

\footnotetext{
${ }^{143}$ Entrevista concedia em 07 nov. 2014.

${ }^{144}$ Fala do narrador Ivan Seixas em entrevista concedida em 08 nov. 2014.
} 
presos e uma equipe multidisciplinar de diversos profissionais. Unindo o tecnicismo e a expertise de profissionais com os olhares sensíveis das próprias testemunhas, está posta a essência do projeto do Memorial: um espaço construído sobre uma diversidade de vivências.

Do desejo de retomada do espaço pelo grupo, no ano de 2007, até sua inauguração em 2009, foram percorridas várias fases. Nas lembranças dos quatro narradores, no entanto, ficaram marcados alguns momentos: a aproximação com os gestores públicos do prédio, "surpreendentemente acolhedora" às suas reivindicações; a escolha por uma construção calcada na diversidade; a necessidade "imediata" em escolher um novo nome para o então Memorial da Liberdade, que representasse verdadeiramente as experiências vividas naquele local; e a participação na reconstituição do espaço, especialmente, as celas.

A concepção do projeto técnico museológico, embora tenha ficado a cargo de equipe multidisciplinar de profissionais especialistas, também contou sobremaneira com referências as reconstituições das lembranças do grupo, sendo este um de seus pontos fortes na construção das bases representativas do Memorial, calcada nas múltiplas visões das próprias testemunhas das experiências daquele espaço.

São os narradores Ivan Seixas e Maurice Politi que, juntamente com Raphael Martinelli, ${ }^{145}$ decidem buscar uma aproximação com o Estado de São Paulo para levar sua reivindicação de transformação do Memorial da Liberdade ${ }^{146}$. Nesse instante, encontram de um modo para eles surpreendente, gestores sensíveis às suas demandas e o suporte necessário ao que, posteriormente, culminaria com a concepção do Memorial da Resistência, como lembra Ivan Seixas:

Então nós viemos aqui conversar com o Secretário de Cultura. $\mathrm{Na}$

\footnotetext{
${ }^{145}$ Embora os narradores não deixem, em vários momentos, de citar a participação dos ex-presos Alípio e Paiva.

${ }^{146}$ No ano de 2004, foi instituída na Secretaria de Estado da Cultura a Estação Pinacoteca, "como parte integrante da Pinacoteca do Estado, do Departamento de Museus e Arquivos", tendo as seguintes finalidades: I - a exposição de parte do acervo da Pinacoteca do Estado ou de obras cedidas em comodato; II - a realização de exposições temporárias; III - o desenvolvimento de trabalho educativo junto à população, em especial com crianças, jovens e portadores de deficiências. Decreto 48.461, de 20 de janeiro de 2004. Disponível em: <http://www.al.sp.gov.br/repositorio/legislacao/decreto/2004/decreto-48461-20.01.2004.html>. Acesso em: 17 mar. 2015.
} 
época o João Sayad, que, para nosso espanto, foi de uma sensibilidade muito grande. Ele não é da área de cultura, mas mostrou uma sensibilidade muito grande. A gente teve uma segunda conversa onde ele falou: "Eu fui lá olhar do que é que vocês estão falando e aquilo lá é um horror. Aquilo lá parece um apart-hotel, está tudo bonito, não lembra o que vocês me falaram, está completamente diferente. O que é que vocês querem fazer?" $E$ a gente falou: "Olha, a gente quer transformar aquilo em um memorial que mostre o que aconteceu ali." ${ }^{147}$

A intenção, na época, era ocupar todo o prédio, como lembra Maurice, como se, somente dessa forma, o trabalho de retomada se cumpriria plenamente: "a nossa ideia inicial era ocupar o prédio todo. O Fórum dos Ex-presos, no início, nas suas intervenções, queria ocupar o prédio todo, porque o prédio todo era do DOPS, o prédio todo era a delegacia."

A receptividade do Estado é merecedora de admiração e gratidão, também segundo a sua fala:

Tivemos a sorte de quem cuidava do DOPS do ponto de vista legal era o Marcelo Araújo, da Cultura, na época era diretor da Pinacoteca, um homem esclarecido, um advogado, que também, muito mais jovem que nós, mas que nos anos 80 ele fez faculdade, na redemocratização. Então, um homem de pensamento liberal, aberto. $^{148}$

O empenho do grupo em convencer o Estado sobre a necessidade e oportunidade de promover a reformulação, teve relevante papel na abertura desta parceria, como narra Elza Lobo: "A ideia do Memorial (da Resistência) acabou sendo aceita pelos dirigentes. Eu acho que ele foi sendo ganho à medida que se foi trazendo debates, trazendo informações." 149

E a atuação do grupo, por meio do Fórum, é tida pela própria equipe técnica do Memorial, como um dos destaques do processo:

[...] entre as premissas e opções, não podemos negligenciar outros aspectos de igual relevância para o delineamento desse processo museológico como, por exemplo, a conquista do Fórum Permanente dos ex-presos e perseguidos políticos do Estado de São Paulo que, neste caso, se traduziu em vontade política para esta nova equação do Memorial. ${ }^{150}$

\footnotetext{
147 Entrevista concedida em 08 nov. 2014.

148 Entrevista concedida em 10 jan. 2015.

149 Entrevista concedida em 08 nov. 2014

150 ARAÚJO, 2009. op. cit. p.55.
} 
Os encontros entre os grupos de ex-presos políticos e os gestores públicos cresciam e a parceria aparentava afinar suas intenções, como recorda o narrador Maurice:

Nós tínhamos conversado com o Secretário da Cultura da época, João Sayad, ele nos recebeu, Martinelli, Ivan e eu, e nós falamos "Olha, secretário, esse lugar tem que ser revitalizado." Ele concordou. E disse: "Mas só que nós vamos fazer isso profissionalmente, não vamos fazer meia-boca." 151

A parceria que se formava naquele momento é reconhecida pelo próprio Estado como aspecto relevante ao sucesso do processo de transformação do espaço, por meio do "trabalho coletivo e multiprofissional" que foi, posteriormente, colocado em prática:

$\mathrm{E}$, notadamente, a opção da equipe por construir este processo museológico contando com a parceria e cumplicidade de alguns dos protagonistas das experiências vivenciadas neste espaço carcerário. $^{152}$

Não só o Estado acatou o pedido de reivindicação social do espaço para transformá-lo, como também decidiu aceitar o envolvimento do grupo de ex-presos na sua própria concepção museológica, no sentido de construir um lugar de memória firmado no "diálogo com àqueles que aqui partilharam experiências, conviveram momentos dramáticos e, por resistirem, garantiram a possibilidade de, hoje, esse espaço encontrar um novo destino, permeado de perspectiva educacional" (ARAÚJO, 2009, p.83).

Essa parceria entre Estado e os ex-presos, no caso do Memorial da Resistência, é tida por Hugues de Varine-Bohan, historiador e arqueólogo francês, que visitou o espaço após sua inauguração, como "um modo de gestão original" e como "um sistema de cooperação exemplar", ${ }^{153}$, que vai se estender para além da inauguração do Memorial, sendo identificado da mesma forma nas suas atividades educativas e culturais cotidianas com a comunidade. Seria, assim, um projeto calcado na multiplicidade dos testemunhos.

A ideia de cooperação dos testemunhos de quem vivenciou as experiências

\footnotetext{
151 Entrevista concedida em 10 jan. 2015.

152 ARAÚJO, 2009. op. cit., p.54-55.

154 POLLAK, 1992. op. cit., p. 2.
} 
no local, no caso, o grupo de ex-presos políticos, ultrapassa a concepção do Memorial estendendo-se até a execução do projeto museológico. A partir da diversidade de recordações será formada a grande "colcha de retalhos" da memória social, em consonância com a defesa de Pollak, segundo a qual a memória é um "fenômeno construído coletivamente e submetido a flutuações, transformações e mudanças constantes." 154

Uma premissa também era certa na visão do grupo de ex-presos políticos: o Memorial "deveria ter o ponto de vista dos personagens, que resistiram a regimes arbitrários e lutaram (e continuam lutando) por um Brasil justo e pela liberdade, sem identificação temporal com qualquer corrente política ou partidária.”"155

A opção por um processo de construção coletiva de formação do Memorial, firmado no aporte das diversas experiências dos ex-presos políticos, sinaliza para a formação de um verdadeiro "vínculo fiduciário" entre Estado e testemunhas, vínculo esse que, segundo Ricceur (2007, 174-175), se constitui no:

[...] assentimento à palavra de outrem, princípio do vínculo social, a tal ponto que ele se torna um habitus das comunidades consideradas, e até uma regra de prudência: começar por confiar na palavra de outrem, depois duvidar, se fortes razões inclinarem para isso.

A operação do ato de narrar pode vir, conforme Ricceur, impregnada de dúvidas quanto à sua confiabilidade. Partindo de representações da vida cotidiana, os relatos são processos compostos de, pelo menos, três fases: "percepção da cena vivida", "retenção da lembrança" e "fase declarativa da narrativa da reconstituição dos traços do acontecimento." (RICCEUR, 2007, p.171). Ao longo desta cadeia de operações em que atua o testemunho, as desconfianças recairiam sobre cada uma dessas etapas, abrindo margem à necessidade de se implementar um processo de apuração de flagrantes distorções.

Ricceur vai então chamar a atenção a uma série de componentes essenciais que vão atribuir maior ou menor grau de confiabilidade às narrativas e que, certamente, em algum momento, foram considerados quando da opção dos usos dos testemunhos para a construção do Memorial: fronteira entre realidade e ficção

\footnotetext{
${ }^{154}$ POLLAK, 1992. op. cit., p. 2.

155 SEIXAS; POLITI. 2009. op. cit. 203.
} 
(realidade factual versus declaração da experiência); autodesignação, atribuição a si da experiência narrada (há uma associação entre a realidade da coisa ocorrida e a presença do narrador nos locais de ocorrência); crédito perante terceiros; aceitação por parte da testemunha em ser convocada em caso de necessário confronto de informações; sua capacidade de reiterar seu testemunho ao longo do tempo; e a institucionalização do testemunho. ${ }^{156}$

Por fim, Ricceur ensina que trabalhar com testemunhos é também trabalhar com uma multiplicidade de representações do passado por meio de "narrativas, artifícios retóricos, colocação de imagens" e outros signos. ${ }^{157}$

Segundo Araújo, é o acolhimento destes diversos aportes que imprime no Memorial da Resistência a noção de resistência política:

\begin{abstract}
Acolhemos os testemunhos de representantes dos ex-presos políticos como os caminhos fundantes para a identificação da construção da noção de resistência que pretendíamos imprimir às soluções expositivas e educacionais. Procuramos identificar os sentidos que eles atribuem às memórias da resistência vivenciada nos diferentes períodos da prisão. E de alguma pudemos partilhar com eles algumas opções em relação aos enfoques temáticos e, consequentemente, algumas revisões sobre as opções de espacialização e concepções dos recursos expográficos. ${ }^{158}$
\end{abstract}

Esta multiplicidade de olhares é que vai permitir a reconstituição das experiências daquele espaço, a exemplo da composição das celas. Desde a intenção de reconstituir o espaço das celas do DEOPS por meio de maquete representativa, o conjunto das falas das testemunhas é que possibilitou a composição do espaço, sendo fruto do conjunto de representatividades nas lembranças de cada um. Neste exercício conjunto, surgem os mais variados componentes espaciais presentes nas narrativas: o tamanho das celas e dos banheiros, os escritos nas paredes, a divisão da carceragem entre feminina e masculina, a existência do "fundão", cela que ficava ao final do corredor, tipos de móveis, espaço total utilizado pelo DEOPS, entre outros.

O que ocorre, neste ponto, é um confronto de subjetividades individuais, "que se reconstitui progressivamente uma forma de verdade, mesmo quando o

\footnotetext{
${ }^{156}$ RICCEUR, 2007. op. cit. 172- 175.

${ }^{157}$ RICCEUR, 2007, op. cit. p. 170.

${ }^{158}$ ARAÚJO, 2009, p 62.
} 
resultado não é autêntico" (DE VARINE BOHAN, 2009, p.209).

Firmada a parceria entre o grupo de ex-presos políticos e o Estado, por meio da Secretaria de Cultura, era hora de trabalhar na concepção museológica. Uma questão, no entanto restava ainda pendente na visão das testemunhas. Desde o início, o grupo sentia a necessidade de ver criado um espaço que refletisse sua verdadeira história, não deixando dúvidas sobre os crimes cometidos pelos agentes de Estado entre aquelas paredes, mas, sobretudo, que representasse a resistência política dentro e fora da carceragem. Ivan e Maurice reforçam que o grupo queria ver representado ali um local, que trouxesse como propositura o rompimento com a sensação de "medo de encarar o passado. ${ }^{159 "}$

O mesmo incômodo sentido em relação à descaraterização advinda com a reforma realizada no espaço, enquanto Memorial da Liberdade, abordada no tópico anterior, se fez igualmente presente em relação ao nome que carregava o lugar.

O narrador Ivan lembra sua indignação à época, já nas primeiras reuniões com os gestores: "com certeza não está correto o nome Memorial da Liberdade, porque ali houve tudo menos liberdade". ${ }^{160}$

É exatamente a mesma forma como a narradora Elza se recorda do retorno ao local, ao falar das sensações do grupo no Memorial da Liberdade, fazendo menção a uma indignação coletiva: "a gente não concordava com aquilo porque não era Memorial da Liberdade".

Esse inconformismo encontrou a acolhida imediata da Secretaria de Cultura, dando início à busca pelo novo nome do Memorial, como lembra Ivan sobre a conversa com o secretário:

Então, Memorial da Resistência, Memorial da Lutas, Memorial da Tortura, o que você quiser, mas da Liberdade não." E então ele falou assim: "Vamos fazer o seguinte, façam o pedido e eu renomeio com o nome que vocês quiserem. Qual é?" 161

O narrador se recorda que o grupo tinha uma ideia muito clara em relação ao memorial que queriam:

[...] a nossa decisão, dos quinze, dezesseis, dezessete, que estavam envolvidos na assessoria, que eram ex-presos, em

\footnotetext{
159 SEIXAS; POLITI. 2009. Idem. p. 199

160 Entrevista concedida em 08 nov. 2014.

161 Entrevista concedida em 08 nov. 2014.
} 
hipótese alguma era de ser alguma coisa que criasse uma aparência de loas à tortura, nem positivamente, nem negativamente. A tortura era uma coisa que estava presente, mas nós queremos homenagear é a resistência. ${ }^{162}$

Era preciso encontrar um nome que pudesse refletir não só a visão do que foi o DEOPS no passado, mas também que representasse adequadamente a ideia que tinham da função daquele espaço no presente. Um nome que representasse um espaço de homenagem às lutas contra um estado de exceção no passado, porém que tivesse fixado no presente. Surgiu, assim, a ideia de homenagear a resistência:

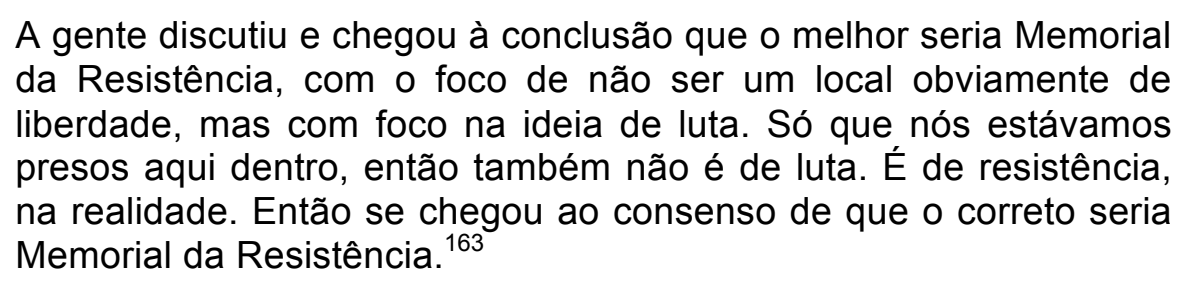

A reformulação do nome daquele espaço aproximaria, então, o expectador da realidade de sua história: "o nome mais lógico para aquele espaço era Memorial da Resistência, visto que as pessoas presas ali sofreram todo tipo de vexames e torturas, todavia resistiram a tudo em nome da dignidade humana. ${ }^{164 "}$

Essa mudança representou, para os próprios agentes públicos envolvidos na proposta de reformulação do espaço, "a possibilidade de ruptura com um conceito pretérito - Memorial da Liberdade - para a construção de uma nova perspectiva conceitual - Memorial da Resistência"165. Indo além, defendem que "a resistência política que se enraizou nos meandros das ditaduras brasileiras e ainda nos mobiliza" ocupa lugar central da nova agenda inaugurada com o Memorial da Resistência.

Essa mobilização de resistência à repressão política a que se referem, das décadas de 1960 e 1970, é considerada por Sérgio Adorno como um primeiro momento em que a sociedade brasileira manifesta publicamente sua indignação e repúdio à histórica cultura de violência no Brasil. Para o autor, os hábitos da costumeira violência se davam indistintamente tanto nos espaços privados quanto

\footnotetext{
162 Entrevista concedida em 08 nov. 2014.

163 Entrevista concedida em 08 nov. 2014.

164 SEIXAS; POLITI. 2009. p. 201.

165 ARAÚJO, 2009. p. 59.
} 
públicos, desde a forma de tratamento dada aos escravos, à mulher e à criança, aos que viviam nas ruas, aos movimentos operários e sociais. E foi justo ao longo da ditadura iniciada em 1964 que a sociedade passou a expressar publicamente sua indignação e discordância em relação às práticas de violência, em manifesta resistência política. Era o início das denúncias em face das violações cometidas pela ditadura e, hábito que, posteriormente, prosseguiria e se fortaleceria ao longo das próximas décadas, já com a volta da democracia, principalmente, diante das ações policiais. ${ }^{166}$

Para a narradora Rose, no entanto, a resistência política sempre esteve presente em vários momentos da história brasileira - desde as lutas de Zumbi dos Palmares e de João Cândido, nas histórias dos escravos negros, que plantavam manga escondidos dos senhores de escravo para deixar como alimento para as suas futuras gerações até ações contra o Estado Novo, e na resistência à ditadura iniciada em 1964.

As histórias de luta e resistência sociais surgem na narrativa de Rose entrelaçando fatos históricos com a própria experiência familiar, como a avó que trabalhava na indústria têxtil quando teve que esconder a gravidez para não ser prejudicada no emprego. Deste fato familiar, Rose extrai sentidos da luta feminista e trabalhista, por exemplo.

Para a narradora, conhecer todo esse processo histórico de resistência brasileira é necessário, inclusive, à compreensão da própria história do Memorial:

Nós formamos a resistência brasileira, que inclui vítimas que foram mortas, desaparecidas, torturadas, nessa área, mas que no pensamento resistiu à ditadura. A gente acha muito bonito ver filme de resistência francesa, italiana, até alemã, inglesa. E nós tivemos muitas resistências. Tivemos resistência ao Estado novo quando ele se tornou "fascistão", nós tivemos a resistência em 64 , em 68, dentro da ditadura tem muitas coisas. Eu acho que a gente integra a resistência brasileira. [...] É tudo um processo e nós vamos chegar no Memorial, mas tem que contar todas essas histórias de resistência. ${ }^{167}$

\footnotetext{
${ }^{166}$ ADORNO, Sergio. As raízes históricas e sociais da violência no Brasil.Canal do Núcleo de Estudos da Violência - NEV-USP. [28 jan. 2015]. Disponível em: <https://www.youtube.com/watch?v=PkTdCtZReX8>. Acesso em: 30 jun. 2015.

${ }^{167}$ Entrevista concedida em 07 nov. 2014.
} 
O sentido de resistência trazido na fala de Ivan faz referência aos feitos de todos aqueles que enfrentaram a ditadura, inclusive dos que morreram lutando contra esse período. Também está na sua fala, a resistência política como representação do próprio processo de reivindicação do prédio e sua retomada pelos ex-presos. É um sentimento expresso de modo bem contundente quando afirma que "a humanidade venceu a barbárie", que "quem manda somos nós" e que "nós fincamos a bandeira da democracia". Esse sentido é também reverberado pelo narrador quando fala dos trabalhos realizados durante as atividades atuais do Memorial, voltados à juventude, e que serão vistos no próximo capítulo.

Para Maurice Politi, esse debate sobre resistência também permanece atual e deve ser incentivado entre os jovens.

O significado da resistência ao qual se referem parece, para Ivan, alcançar a geração de jovens com quem o Memorial se propõe a dialogar, despertando nele uma forte emoção ao citar as mensagens deixadas nos livros de registros dos visitantes do Memorial: "Eu sempre vou lá e sempre olho e saio assim com uma emoção redobrada. Deixam nome, sobrenome, local e comentário. Você imagina o que é você ler 'Obrigado, resistentes! Temos democracia graças a vocês'. Isso derruba qualquer um". ${ }^{168}$

O narrador cita, ainda, a nova conotação dada à palavra resistente e a força que ela apresenta para redefinir a visão social sobre as lutas políticas. Com a ampliação dos debates públicos, ressalta: "antes disso eu, Ivan, era terrorista, depois disso eu passei a ser resistente." Todas essas falas justificam e legitimam a escolha do novo nome do espaço: Memorial da Resistência.

Passando então para a fase da concepção museológica, chega o momento em que se definem os objetivos do espaço de memória, o público que se quer dialogar, bem como a metodologia que será utilizada. Para alcançar seus objetivos, um projeto de memorial deve responder a uma série de questionamentos de modo a auxiliar na definição das escolhas que devem ser feitas para a construção do espaço:

Qual o propósito e o objetivo do projeto? Será que ele visa facilitar a reconciliação? Será que reconhece grupos específicos de

\footnotetext{
${ }^{168}$ Entrevista concedida em 08 nov. 2014.
} 
vítimas? Fornece lições para as futuras gerações? [...] Qual a necessidade (e de quem) o projeto irá responder? Como, então, essas iniciativas de memorialização se relacionam com outras iniciativas de memorialização no cenário nacional? De que forma, se houver, elas dialogam umas com as outras? Que histórias (e de quem) serão contadas? [...] a iniciativa irá inflamar as tensões pósconflito ou contribuirá para o processo de construção da democracia? Se o projeto fará perguntas difíceis relacionadas com, por exemplo, a reconciliação, o perdão e a justiça, a sociedade/comunidade está pronta para se desenvolver com essas questões? ${ }^{169}$

Os lugares de memória, enquanto "suportes ou propagadores de memória coletiva" 170 , quando versam sobre violações sistemáticas de direitos humanos, devem se propor à múltiplas funções: conhecimento da verdade; medida de reparação simbólica; reconhecimento das vítimas e sua reintegração social; reconstrução de relações sociais anteriormente divididas; evidência no auxílio à punição; garantias de não-repetição ${ }^{171}$; contribuição para o luto e a cura; demarcação de uma nova identidade nacional; e promoção do diálogo público construtivo ${ }^{172}$.

Solicitado pela direção da Pinacoteca à equipe multidisciplinar formada por profissionais da Museologia, História e Educação ${ }^{173}$, o Projeto Museológico de Ocupação foi entregue em 10 de agosto de 2007, contendo uma proposta inicial de reformulação museológica do espaço. O narrador Maurice conhece os detalhes da equipe multidisciplinar:

Tinha três vertentes: a parte arquitetônica, que ficou com a Pinacoteca, para fazer a reforma do lugar; a museológica, que ficou com a professora Cristina Bruno, e ela convocou a Katia para ajudar; e a parte de história ficou com a professora Maria Luiza Tucci Carneiro, da USP, trabalhava muito com arquivo, uma

\footnotetext{
${ }^{169}$ NAIDU, 2010, op.cit., p. 23.

${ }^{170}$ INSTITUTO DE POLITICAS PÚBLICAS EM DIREITOS HUMANOS DO MERCOSUL (IPPDH). Principios Fundamentales sobre Sitios de Memoria, XXII Reunião de Altas Autoridades em Direitos Humanos e Chancelarias do Mercosul e Estados Associados (RAADH), 2012, Porto Alegre. Disponível em: <http://www.ippdh.mercosur.int/backend/Uploads/Sitios_de_memoria_FINAL_ES_INTERACTIVO.pd $f>$. ${ }^{17 i}$ Idem.

${ }^{172}$ NAIDU, 2010, op. cit., p. 12.

${ }^{173}$ O Projeto foi concebido pela museóloga Maria Cristina Oliveira Bruno, do Museu de Arqueologia e Etnologia - MAE/USP), pela historiadora Maria Luiza Tucci Carneiro, da Faculdade de Filosofia, Letras e Ciências Humanas - FFLGH/USP) e pela educadora Gabriela Aidar, da Ação Educativa da Pinacoteca do Estado de São Paulo).
} 
especialista em arquivos, ela que fez toda a parte de concepção de história. ${ }^{174}$

Aprovado pela Secretaria de Cultura e pelo Governo do Estado, o Projeto pauta-se na carência de espaços-símbolos que representem "a história da repressão, assim como a da resistência no Brasil contemporâneo"175, e tem como premissas: dar novo sentido ao abandono; oferecer nova perspectiva de interpretação aos vestígios das experiências vividas no DEOPS/SP e ressignificar artefatos permitindo novas compreensões.

Para dar conhecimento ao histórico do DEOPS e a trajetória de ocupação do prédio, o Projeto defende a priorização de algumas características, tais como:

[...] evidenciar os vetores de memória, de uma instituição de controle do exercício da cidadania [...]; difundir a importância da preservação dos vestígios da memória; problematizar os distintos caminhos da memória da repressão e da resistência política; e atualizar as questões relativas à repressão e resistência para os dias atuais. ${ }^{176}$

O Projeto apresenta proposta de reocupação espacial contemplando a reconstituição das celas, momento em que já promove as escolhas dos temas que serão representados: tributo à liberdade; tributo à resistência; e diálogo entre repressão e resistência, por exemplo. As formas de representatividades também são apresentadas por meio do Projeto: sons e imagens; depoimentos; iconografia e etc. $^{177}$

Sobre estes fundamentos, o Projeto do Memorial da Resistência se firma em alguns alicerces: trazer um "novo olhar" para o prédio e suas histórias; promover constante diálogo entre passado, presente e futuro; e exaltar a resistência em detrimento do sofrimento.

Nesse último ponto, Ivan Seixas afirma que a composição de todo o espaço foi pensada não para ser de "loas à tortura, nem positivamente, nem negativamente." Não nega a presença de referências à tortura no Memorial, uma

\footnotetext{
174 Entrevista concedida em 10 jan. 2015.

${ }^{175}$ BRUNO, 2009. op. cit. p. 42.

${ }^{176}$ Idem, 2009. p. 43.

177 BRUNO. 2009. op. cit. p. 46.
} 
vez que ela era rotina na vida dos presos do DEOPS/SP e, portanto, também faz parte das suas recordações. No entanto, nas escolhas das representatividades que se fariam presentes no Memorial houve uma opção bem definida por destacar a "resistência política", mesmo quando se aborda repressão, controle e violação: "Não faz sentido você ficar mostrando show de horrores em que as pessoas sairiam correndo, não querem voltar mais. Tem que ser alguma coisa propositiva, reflexiva, que fale disso, mas que não seja uma coisa assustadora." 178

Um dos objetivos estampados na concepção do Memorial está em propor ao visitante o lançamento de um novo olhar". Diz-se novo por, justamente, lançar luz sobre o edifício e suas histórias, por retirar o véu que encobria as experiências vivenciadas naquele espaço, principalmente, para as novas gerações. O projeto de reconstituição pretendeu fazer visível não só a parte arquitetônica, mas as histórias que habitaram suas paredes e que fazem parte de sua vida.

Para alcançar este objetivo, o projeto museológico propôs, ainda, um constante diálogo entre repressão e resistência, porém inspirado na "valorização da solidariedade, dos princípios democráticos e do respeito à diferença." ${ }^{179}$ Deixou claro, também, o diálogo que trava, em toda sua concepção, entre os acontecimentos do passado e do presente, característica que se verá mais claramente quando da explanação de suas ações de integração com a sociedade. ${ }^{180} \mathrm{Na}$ sua essência, o Memorial é, ainda, "um tributo a todos os que, imbuídos do ideal de justiça e democracia, lutaram e lutam contra a opressão."

O projeto estava finalmente pronto e Maurice se lembrou do convite feito pelo Estado para que o grupo continuasse no trabalho "[...] (o Secretário de Cultura) Pegou o plano e entregou para nós. Falou: "Olha, esse é o plano, mas eu quero que vocês opinem. E não só queremos que vocês opinem como queremos que participem da concepção e de quando a gente for botar em prática."

O narrador Maurice recorda que, em um dado momento, as participações de cada um dos ex-presos foram se dando de um modo diferente, "como é de esperar em um processo desses", segundo ele:

Depois que esse grupo se formou e começou a trabalhar, eles

\footnotetext{
178 Entrevista concedida em 08 nov. 2014.

179 ARAÚJO, 2009. 75.

${ }^{180}$ Idem, p. 75.
} 
pediram que participássemos. E nós fomos, claro. Começamos a participar ativamente. Alguns mais ativamente que outros. Como é normal em um processo desse. ${ }^{181}$

Em 1 de maio de 2008foi dado início à implantação do novo Projeto Museológico do atual Memorial da Resistência, "em referência e homenagem ao espírito de luta e defesa dos valores democráticos contra a ditadura militar." ${ }^{\text {182 } \mathrm{A}}$ mudança do nome foi oficializada em uma cerimônia que marcou o início da implantação do novo projeto museológico que surgia. A data escolhida foi marcada de grande significado e é rememorada nas palavras de Ivan Seixas de modo muito simbólico pela homenagem ao Dia do Trabalhador:

Para você ver como é isso, quando o João Sayad mudou o nome ele falou assim: "Vamos fazer um ato para mostrar que mudou 0 nome." Aí nós escolhemos dia $1^{\circ}$ de maio, não por acaso. "Em $1^{\circ}$ de maio, nós vamos fazer um ato para rebatizar." Aí foi uma emoção muito grande, $1^{\circ}$ de maio, data histórica para os trabalhadores, nós todos socialistas temos um vínculo muito grande com isso. ${ }^{183}$

A ocasião contou com episódio que Ivan Seixas recorda, achando graça, em referência à presença de um grupo de integralistas cujo movimento teve início em 1932, sob o lema "Deus, Pátria e Família" e as bases da "hierarquia e da disciplina", para a integração de uma pátria "organizada, una, indivisível, forte, poderosa, rica, próspera e feliz": ${ }^{184}$ O momento foi, para Ivan, marcado de tensão, pela possibilidade do grupo desencadear alguma manifestação violenta, uma vez que anunciaram estar lá para mostrar o "repúdio às indenizações milionárias para os terroristas."

Adiantando o modo como vê hoje as manifestações em face das

\footnotetext{
${ }^{181}$ Entrevista concedida em 10 jan. 2015.

${ }^{182}$ MENEZES, Caroline Grassi Franco; NEVES, Kátia Felipini. O programa museológico e a abertura de novos caminhos preservacionistas e educacionais: rotas para um novo caminho. In: ARAÚJO, Marcelo Mattos; BRUNO, Maria Cristina Oliveira. (Coord.) Memorial da Resistência de São Paulo. São Paulo: Pinacoteca do Estado, 2009.p. 29-38.

${ }^{183}$ Entrevista concedida em 08 nov. 2014.

${ }^{184}$ Segundo o "Manifesto de 07 de outubro de 1932": "O Integralismo não é um partido: é um movimento. É uma atitude nacional. É um despertar de consciências. É a marcha gloriosa de um povo. O Integralismo proclama que não há direito algum que se sobreponha aos direitos da Nação, limitados esses pelos princípios do Direito Natural baseados em Deus, pois assim essa garantirá eficientemente os direitos dos indivíduos, dos grupos de indivíduos, dos municípios, das províncias, dirimindo contendas, harmonizando interesses." Disponível em:<http://www.integralismo.org.br/?cont=825\&ox=2>. Acesso em: 30 mai. 2015.
} 
divergências políticas, em um Estado Democrático, dotado de instituições que asseguram o cumprimento das liberdades democráticas, Ivan recorda que negociou com eles que fizessem "pacificamente" sua manifestação. Ao recordar o episódio, o narrador lembra que fez questão de dizer ao grupo que até mesmo aquele momento de livre expressão só era possível graças ao trabalho de resistência que conquistou a democracia, o que, para ele, foi uma "demonstração do que é o improviso e como mexer com os caras."

Iniciada a implantação do novo projeto, foram sendo realizadas reuniões para coleta dos testemunhos dos ex-presos, enriquecendo o processo reconstituição das memórias que preencheria os significados do Memorial:

Essa dinâmica, que contou com a coleta de testemunhos e
reuniões com grupos de ex-presos, foi intensificada e desdobrada
em reuniões setoriais com distintos segmentos das equipes de
especialistas e reuniões gerais com todos os participantes do
projeto. À medida que o trabalho foi crescendo, as seleções e
opções se mostraram mais multifacetadas, pois contávamos com
aportes dos protagonistas das memórias, mas, também, com
subsídios de diferentes especialistas que sempre atuaram de forma
muito propositiva em relação ao projeto como um todo. ${ }^{185}$

Maurice Politi recorda o envolvimento do grupo com a equipe de profissionais especialistas, já apontando para intensidade do trabalho: "E foi esse o processo de aproximação com a equipe museológica, a equipe de historiadores, as nossas entrevistas, todo nosso depoimento, horas e horas que a gente passou." ${ }^{186}$

O movimento compartilhado no Memorial da Resistência envolveu o grupo para além da indicação de projeções museográficas. O processo de tomada de decisão faz com que a responsabilidade pelas escolhas seja compartilhado em uma demonstração de verdadeiro compromisso com a execução de um projeto desse porte, trazendo "as testemunhas também como indivíduos, na lista de atores-realizadores do Memorial" (DE VARINE BOHAN,2009 p.212).

Em toda dinâmica de trabalho coletivo, à medida que se dá voz a uma diversidade de visões - característica natural da memória coletiva -será igualmente construída a arena de disputa, trazida por Pollak. ${ }^{187}$

\footnotetext{
${ }^{185}$ ARAÚJO. 2009, p.65.

${ }^{186}$ Entrevista concedida em 01 out. 2014.

${ }^{187}$ POLLAK. 1989, p. 5
} 
Em episódio que exemplifica o exercício de disputa entre as diversas recordações no trabalho construir o Memorial, o narrador Ivan Seixas relembra, achando graça, que saiu "vencedor". Chamados a reconstituir a carceragem na forma de maquete, que seria apresentada aos visitantes, Ivan recorda que insistiu com o grupo na existência de uma "escadinha" no fundo do corredor de banho de sol, da qual nenhuma outra testemunha se lembrava. Aquele objeto do qual ninguém mais se recordava, Ivan tinha a certeza da sua existência, já que fazia uso para alívio das dores na coluna. Suas lembranças do objeto não foram compartilhadas pelos demais presos que insistiam na sua ilusão, até que um fotógrafo procurou o grupo com fotos da tal escada. Do episódio, o narrador dá risada: "aí todo mundo: "Tá bom, tá bom, você tem razão. Você é o moleque, sempre tem razão." Começaram a brincar comigo. E na maquete foi parar a escadinha." 188

Mesmo apontando divergências nas recordações do grupo, Ivan tem consciência de que o Memorial é resultado de um esforço coletivo em reconstituir uma memória que não pertence a um ou outro, mas é, antes de acima de tudo, também de uma coletividade:

Estou contando para mostrar como foi o processo de construção coletiva. E ainda bem que a gente conseguiu reunir um grupo de pessoas em que a marca desse grupo foi a generosidade. Não tem "a minha organização, a minha história." É a história de todos nós. Então, esse negócio que eu estou contando eu falei: "Tá bom, eu abro mão, não teve escada, esquece." Aí um dia depois falaram "Tá bom Ivan, você tinha razão" (risadas). ${ }^{189}$

À medida que trabalham, no projeto do Memorial, o espaço nas suas lembranças, surgem peculiaridades que marcaram de modo bem definitivo um ou outro narrador. A narradora Rose, quando fala da sua percepção sobre o tamanho das celas, lembra que as via muito maiores na juventude do que agora, quando de seu retorno ao local. Neste momento, toma sua percepção em analogia à capacidade da juventude de ver as coisas de forma ampliada, tanto a dor quanto a resistência. A narradora celebra esta virtude:

A gente pensa com a vida que quando a gente é mais moça e é

\footnotetext{
${ }^{188}$ Entrevista concedida em 08 nov. 2014

189 Entrevista concedida em 08 nov. 2014.
} 
criança, as coisas parecem muito maiores. Então aí que a gente vê como a juventude é bonita, que conserva essa lembrança daquele mundo tenebroso, terrível, imenso na sua cabeça e, ao mesmo tempo, da sua própria luta. ${ }^{190}$

Em outros momentos de sua fala, Ivan continua a citar detalhes espaciais do local, demonstrando orgulho em manter na memória as lembranças das minúcias daquele espaço, reforçando que foi o preso do grupo que mais tempo ficou no local: "Eu conheço e conheci várias fases. A época que não tinha beliche e a época que tinha. A época que tomava banho de sol e a época que não tomava. Então, teve vários momentos."191

O trabalho de reconstrução espacial envolveu o grupo de maneira bem intensa. Esse momento, inclusive, foi considerado pela equipe museológica como "a parte mais difícil de equacionamento expográfico". Foi quando se exigiu o esforço conjunto de recordar problemas e tragédias, dores, inseguranças e perdas, tudo isso permeado por demonstrações de coragem e afeto durante os tempos de passagem pelo DEOPS/SP. ${ }^{192}$ Ao recordarem esse período do processo de construção do Memorial, há em todas as falas bastante ênfase nesse trabalho. Ivan Seixas rememora a colaboração na reconfiguração das celas:

As celas, nós reconstituímos. A cela é reconstituída. [...] Nós é que fizemos o exercício de recuperação da memória para lembrar não só da planta, mas também dentro da cela que estava mais preservada arquitetonicamente. Que cor de parede, como era a iluminação, o banheiro, o piso. Tudo isso a gente fez um exercício para reconstituir: "eu lembro que era assim", "eu lembro que era assado, e tal." 193

O autor da ideia de tentar caracterizar as celas o mais próximo da realidade, não surge de maneira clara nas lembranças da narradora Rose, que lembra ter ido ao local para escrever na parede e ter colaborado com a construção da maquete, juntamente com Alípio Freire.

Ivan relembra a tarefa de reconstituição dos nomes dos presos nas paredes, por meio de escrituras feitas à época para registro dos que passavam por aquela

\footnotetext{
${ }^{190}$ Entrevista concedida em 07 nov. 2014.

191 Entrevista concedida em 08 nov. 2014

192 ARAÚJO. 2009. 82.

193 Entrevista concedida em 08 nov. 2014.
} 
carceragem, como um processo coletivo, onde todos foram "colocando a mão na massa":

Depois teve a reconstituição das marcas na parede. Como preso não tem nada para fazer, então a perninha do "i" você leva uma semana fazendo aquele "i". A gente tinha que fazer em três dias. Então arrumamos pregos, ferramentas e ficamos (som de arranhado) escrevendo aquelas coisas todas. E todo mundo escrevendo e lembrando do que a gente viu.

Nessa função de deixar gravado no concreto as lembranças das histórias vivenciadas, por meio da reprodução dos escritos dos presos, o narrador Ivan vê não só um "esforço de memória", mas o próprio sentido de homenagens às histórias vividas e a todos os que passaram por lá, sobreviventes ou não:

Fizemos os nossos nomes, os nomes de companheiros que tinham morrido, lembrando como é que foi. Então, para nós foi uma valia muito grande, não só o esforço de memória, mas, principalmente, a justiça que a gente queria fazer com os que morreram. Tanto os que morreram torturados, quanto os que passaram aqui e já morreram. Então era preciso lembrar os nomes deles e botar. ${ }^{194}$

Foi nessa fase do processo de construção do Memorial, que Ivan se deu conta da força que aquelas palavras gravadas por outros presos nas paredes das celas teve em sua vida, tanto na época da prisão no DEOPS/SP, quanto na própria época de construção do Memorial:

Uma das frases que me marcou muito, e que eu sempre falo isso por causa do escritor, que é o José Bento Monteiro Lobato, quando eu cheguei à cela seis tinha escrito na parede "Aqui esteve JB Monteiro Lobato." É de quando ele esteve preso aqui na época da campanha do Petróleo é Nosso. E aquilo, eu moleque - eu tinha dezesseis anos quando fui preso e eu tinha lido Monteiro Lobato eu fiquei encantado. Imagina: "eu tô preso na mesma cela que o Monteiro Lobato!" Fiquei emocionado. Quando eu chego aqui e vi que sumiram com tudo, isso não pode, a primeira inscrição que eu fiz foi isso: "Aqui esteve JB Monteiro Lobato." Porque achei que assim era uma homenagem a ele, a luta dele. ${ }^{195}$

A reconstituição das celas foi uma das últimas etapas antes da inauguração do Memorial. Após um longo processo de esforço da memória e de diálogos e negociações múltiplas, em meio à necessidade de compatibilizar inúmeras visões e

\footnotetext{
${ }^{194}$ Entrevista concedida em 08 nov. 2014.

${ }^{195}$ Entrevista concedida em 08 nov. 2014.
} 
expectativas, o Memorial da Resistência foi inaugurado em 24 de janeiro de 2009. O trabalho do grupo de ex-presos, no entanto, não se encerrava ali. Ao contrário, a abertura do Memorial ao público inaugurava, em verdade, um espaço de atuação efetiva para o grupo junto à comunidade e, em especial, junto à juventude, em uma nova temporada de atuação: o Memorial da Resistência em ação. 


\section{"A HUMANIDADE VENCEU A BARBÁRIE"}

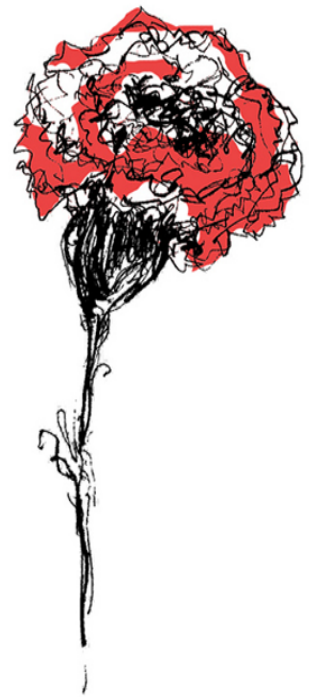

http://p3.publico.pt/sites/default/files/4_2013/cravo_mleme.png Ilustração 2: Cravo vermelho. Autor desconhecido. 


\section{2 "A HUMANIDADE VENCEU A BARBÁRIE"196: MEMORIAL DA RESISTÊNCIA COMO ESPAÇO VIVO DE EXERCÍCIO DA CIDADANIA}

Este segundo capítulo trata das narrativas do grupo de ex-presos políticos do DEOPS/SP sobre suas experiências nas atividades que dão vida ao Memorial da Resistência, desde as vésperas de sua inauguração, ainda no ano de 2008 , até a atualidade das entrevistas nos anos de 2014 e 2015.

A partir delas é possível analisar o Memorial sob os aspectos da Nova Museologia ou sociomuseologia, bem como sob as definições internacionais de sítios de consciência, enquanto "espaços-vivos" de construção e diálogo com a comunidade. Apresentadas as atividades atuais de que se vale o Memorial, e identificadas aquelas nas quais mais se envolvem os ex-presos políticos, essas são analisadas à luz de dois compromissos assumidos pelo grupo de narradores: com a memória da resistência e com a juventude. São analisadas, ainda, duas formas destacadas de sua atuação: por meio dos encontros de gerações e pelas marcas de suas recordações reconstituídas no concreto do Memorial. Por fim, são apontadas algumas percepções do grupo sobre os resultados do Memorial da Resistência e a própria presença de suas marcas no espaço.

\section{1 "VOCÊ NÃO PODE DEIXAR O BARCO PARADO, TEM QUE TOCAR"197: PARTICIPAÇÃO NAS ATIVIDADES DO MEMORIAL DA RESISTÊNCIA}

Por meio de um processo de memorialização, segundo o qual a memória se perpetua por meio de lembrança, homenagem e reconhecimento, ${ }^{198}$ é possível atuar na superação de violações de direitos humanos. Na reconstituição das experiências do passado, a memorialização não se propõe somente a trabalhar o concreto, o cimento e o tijolo, mas também referenciais intangíveis - datas comemorativas, danças, cheiros, cores, cultos, ritos, cultura e arte.

A esse conjunto de referenciais que se prestam a reconstituir uma

\footnotetext{
${ }^{196}$ Fala de Ivan Seixas em entrevista concedida em 08 nov. 2014.

${ }^{197}$ Fala de Elza Lobo em entrevista concedida em 08 nov. 2014.

198 NAIDU, Ereshnee. op. cit., p. 11.
} 
experiência de vida, quando ricos de significado, enigma e paixão se denomina "espírito do lugar":

O espírito do lugar é definido como os elementos tangíveis (edifícios, sítios, paisagens, rotas, objetos) e intangíveis (memórias, narrativas, documentos escritos, rituais, festivais, conhecimento tradicional, valores, texturas, cores, odores, etc.) isto é, os elementos físicos e espirituais que dão sentido, emoção e mistério ao lugar. ${ }^{199}$

O sentido "espiritual", no caso, não faz referência ao religioso, mas ao "animado", ao que tem vigor e vivacidade, em alusão a um conjunto de aportes que, indo além de mera exposição de objetos à disposição de um mero espectador, é rico de significados. Nesse sentido, a forma como este conjunto de signos salvaguardados vai dialogar com a comunidade diz muito sobre os objetivos que o lugar de memória quer alcançar: se de uma simples exposição ou se espaço verdadeiramente transformador.

Para trilhar o segundo caminho, é preciso preencher o local de "engajamento cívico" e "participação pública":

Para construir uma cultura de democracia que seja baseada no respeito aos direitos humanos, ao mesmo tempo em que assegure a não repetição de violações, sociedades pós-conflito precisam envolver ativamente o público nas questões relacionadas com 0 passado e imaginar um futuro baseado na paz e na não repetição. ${ }^{200}$

A importância da transcendência das alusões físicas, a partir de referências capazes de comover o visitante, também é percebida pelos próprios narradores, como na fala de Elza Lobo, ao afirmar que "o espaço físico é importante, mas ele tem que ter todo um lado de dar conteúdo para que os que estão chegando realmente percebam o que aconteceu e se interessem em aprofundar."201

Seguindo a teoria da Nova Museologia ou sociomuseologia que, a partir da década de 1960, firma suas bases em defesa de espaços de memória que atuem

\footnotetext{
${ }^{199}$ D INTERNATIONAL COUNCIL ON MONUMENTS AND SITES. Declaração de Québec sobre a preservação do "Spiritu loci". Disponível em: <http://www.international.icomos.org/quebec2008/quebec_declaration/pdf/GA16_Quebec_Declaratio n_Final_PT.pdf>. Acesso em: 26 jul. 2015. Disponível em: $<\bar{h}$ ttp://Www.icomos.org/quebec2008/quebec_declaration/pdf/GA16_Quebec_Declaration_Final_PT. pdf>Acesso em: 20 mai. 2015.

${ }^{200}$ NAIDU, op. cit. p.16.

${ }^{201}$ Entrevista concedida em 08 nov. 2014.
} 
por meio da promoção do diálogo e da reflexão política, mas conectados econômica e socialmente com a comunidade com quem dialoga, De Varine-Bohan, propõe um afastamento do conceito mais tradicional e conservador dos museus. $O$ autor aponta para um conceito mais progressista, no qual os espaços são participativos, dirigidos "para" e "pela" comunidade, de modo a refletir seus anseios e necessidades:

Nessa abordagem, claramente política no sentido mais nobre da palavra, trata-se de utilizar o museu e a educação patrimonial para conscientizar os membros das comunidades, torná-los capazes de autonomia e de iniciativa, prepará-los para uma participação dinâmica no desenvolvimento de seu território e, em geral, na vida pública. ${ }^{202}$

Quando estudou o Memorial da Resistência, ainda no ano de 2009, logo após sua inauguração, De Varine-Bohan viu o projeto como um "reflexo da comunidade de militantes contra a ditadura e das vítimas da repressão", além de estar enraizado e ser direcionado à comunidade local, referindo-se ao alcance junto à sociedade de São Paulo. ${ }^{203}$

Os espaços que seguem essa proposta podem ser compreendidos enquanto "locais históricos, museus e iniciativas dedicadas a lembrar as lutas do passado e enfrentar legados contemporâneo" ${ }^{204}$, colocando-se a serviço de uma forma contemporânea de pensar as experiências de violações de direitos humanos praticadas no passado. Propõem-se, assim, a promover o diálogo entre passado, presente e futuro, por meio da reflexão política e social:

Interpretam a história através do local; empreendem programas que estimulam o diálogo sobre questões sociais prementes; promovem valores humanitários e democráticos como função primária; e compartilham oportunidades do envolvimento público em questões levantadas no local. $^{205}$

Ainda, segundo De Varine-Bohan (2005, s/p), é na participação social que o espaço encontra sua "vocação política":

E chegamos finalmente ao que é mais repreensível no museu

\footnotetext{
${ }^{202}$ DE VARINE-BOHAN, Hugues. O museu comunitário é herético? Rio de Janeiro:Associação Brasileira de Ecomuseus e Museus Comunitários, 2005.

${ }^{203}$ DE VARINE-BOHAN, 2009, p. 212.

${ }^{204}$ NAIDU, p.7.

${ }^{205}$ NAIDU, p.7.
} 
comunitário, aos olhos do mundo dos museólogos profissionais: ele mostra convicto e sem complexos sua vocação política, pois quer ser um instrumento de desenvolvimento do território e da participação da comunidade e de seu patrimônio nesse desenvolvimento.

$\mathrm{Na}$ participação efetiva da sociedade, é possível recuperar, como compreende Ecléa Bosi, a dimensão humana do espaço urbano, uma das questões políticas das mais urgentes da atualidade, segundo a autora. ${ }^{206}$

Esse envolvimento dos ex-presos políticos do DEOPS/SP na concepção do Memorial é que dá, ao espaço, o caráter de proximidade e interesse com as questões políticas:

Esta não é uma exposição fria e distante de eventos mais ou menos antigos, analisados e apresentados por historiadores, utilizando documentos e pesquisas de tipo antropológico. São histórias contadas pelos que a viveram e dentro do contexto da grande história, para permitir que os visitantes se conscientizem da realidade cotidiana dos eventos que ocorreram aqui, em outros locais do estado de São Paulo e por todo o país (DE VARINEBOHAN, 2009, p. 211).

Para De Varine-Bohan (2009, p. 211), a atuação efetiva daqueles que vivenciaram experiências no local faz do Memorial "um instrumento vivo e dinâmico de mobilização e de transmissão da memória de uma época em benefício da geração presente." A riqueza advinda com a participação dos ex-presos nas atividades do Memorial se aproxima do ideal traçado pelo autor sobre os "museus comunitários", quando permite que o espaço seja formado a partir dos referenciais dos sujeitos sociais e não de especialistas. Esses últimos, como se viu no processo de concepção do projeto museológico, são importantes e atuam como necessário apoio técnico. Mas as escolhas, de acordo com De Varine-Bohan (2005, s/p), devem contar com a efetiva participação social:

Para o museu comunitário (ou ecomuseu ou ainda o museu territorial, na medida em que eles sejam realmente comunitários), trata-se do patrimônio reconhecido como tal pela comunidade e por seus membros. É o capital cultural coletivo da comunidade, ele é vivo, evolutivo, em permanente criação. Os responsáveis do museu utilizarão esse capital para atividades inscritas na dimensão cultural do desenvolvimento do território e da comunidade. A conservação é

\footnotetext{
${ }^{206}$ BOSI, 2003, p.76.
} 
uma responsabilidade e uma tarefa coletiva da comunidade, sendo os profissionais do museu essencialmente apoio técnico e científico.

No Memorial da Resistência, o "capital coletivo da comunidade" a que se refere o autor, seria o conjunto de recordações que são reconstituídas pelo conjunto de testemunhas do DEOPS, ou seja, dos ex-presos políticos.Durante as últimas décadas a disputa pelas lembranças e esquecimentos da ditadura tiveram como vencedor o Estado violador, que narrou como e o que quis. Retomar o espaço é então reconfigurar o campo de disputa da memória social e assumir a responsabilidade sobre o capital cultural a ser preservado, trazido pelo autor.

A presença e a participação social convertem o Memorial exatamente naquilo que os narradores Ivan Seixas e Maurice Politi queriam quando decidiram integrar o projeto que faria nascer o Memorial da Resistência:

Nossa intenção primeira era fazer que o espaço adquirisse palavra. Porque o espaço sem palavras, mesmo que ainda tivesse (algo que não ocorria) placas explicativas, não é um espaço vivo. E o que queríamos - e fizemos a equipe entender - é que o espaço do exDEOPS fosse, a partir deste projeto, um ESPAÇO VIVO. ${ }^{207}$

A ideia de fazer do espaço do Memorial uma ágora foi a contrapartida negociada pelo grupo com os agentes públicos do Memorial, permitindo que os expresos políticos ocupassem o espaço. Participar somente da composição museológica, como também fizeram, não estava nos planos do grupo. Era preciso ir além. Havia uma preocupação em fazer do lugar um "instrumento vivo" em referência, a dois aspectos: em primeiro lugar, poder gravar as marcas das reconstituições de suas lembranças no Memorial e, em segundo, poder promover o diálogo com a comunidade: "mais vital para nós era o relato das pessoas que ali tinham estado e as consequências que esse relato teria sobre as pessoas que o fossem visitar, a partir de sua reforma."208

A vitalidade do espaço, ao permitir que as histórias de vida sejam novamente presentificadas e, em certa parte, vivenciadas, está também na percepção da narradora Rose Nogueira:

Você chega lá e escuta a história de cada um, da prisão e tudo.

207 SEIXAS; POLITI, 2009, p. 203

208 SEIXAS; POLITI, 2009, p. 203. 
Você vê as celas, você tem oportunidade de reviver a história. Por isso o Memorial é não um museu de exposição, é uma coisa viva. ${ }^{209}$

A presença e a participação cotidianas dos ex-presos políticos nas atividades do Memorial é um diferencial nas palavras de Elza Lobo. Considerando o tempo transcorrido desde as experiências da ditadura, essa proximidade é que permite um diálogo profundo com as novas gerações:

O que tem muito também que o pessoal organiza é de quando vem
a escola, sempre ter alguém que possa está vindo conversar com
os alunos. Assim eles ficam sabendo o que aconteceu, como é que
aconteceu. Na verdade, como são quarenta e tantos anos fica
como se fosse uma distância muito grande e as pessoas
desconhecem o que acontecia naquele momento. [... $]^{210}$

Ao tempo em que destaca a "distância muito grande" entre as experiências da ditadura e o presente dessa juventude, Elza também aponta para a existência de um fio condutor capaz de ligar essas temporalidades: justamente o encontro entre gerações. E parece ser no diálogo constante com a comunidade, que a narradora vê o caminho possível na contribuição para a não-repetição dos atentados aos direitos humanos. .Participar das atividades do Memorial em contato direto com os visitantes, dialogando com eles a partir da narrativa de suas experiências, seria a melhor forma de despertá-los não só para os acontecimentos do passado, mas também para a necessidade de se manter alerta na prevenção de novas violações. A fala de Elza segue imbuída nesse sentido:

E no Memorial você pode passar as informações. Recebemos no Memorial desde escolas que têm adolescentes até pessoal de faculdade, mais adultos. Eles ficam surpresos. É estranho isso. É aquela ótica de que você tem que estar presente e mostrando o que aconteceu para que não mais aconteça. ${ }^{211}$

As condições de diálogo que o Memorial da Resistência proporciona, permitem, segundo o estudioso De Varine-Bohan, por meio de mecanismos que superam "informações neutras e atitudes passivas", a absorção de conhecimento, a

\footnotetext{
${ }^{209}$ Entrevista concedida em 07 nov. 2014.

${ }^{210}$ Entrevista concedida em 08 nov. 2014.

${ }^{211}$ Entrevista concedida em 08 nov. 2014.
} 
germinação de pensamento crítico e o comprometimento com o futuro. ${ }^{212}$

Para Elza, ainda, a participação dos ex-presos nas atividades do Memorial é uma forma de "mostrar como o ser humano tem a capacidade de dar a volta por cima do que aconteceu e como é que você se reorganiza para caminhar e transformar essa realidade." É nesse encontro que as vozes daqueles que vivenciaram as experiências do passado encontram propagação, não para reverberar a visão do sofrimento dos tempos passados, mas com a perspectiva da resistência e da superação. Afirma, ainda, referindo-se ao coletivo de ex-presos políticos, que é exatamente o que vêm tentando fazer nesses anos por meio de seminários e reuniões com escolas: "então a gente procura fazer com que em diferentes lugares as pessoas saibam o que aconteceu para que não mais aconteça. Para isso você tem que participar no dia a dia das diferentes atividades, fazer debates nas faculdades." 213

O contato com os visitantes parece se dar em uma via de mão dupla. Não só as testemunhas do passado transmitem suas recordações aos jovens, mas também, certamente, esses se deixam afetar pelos ouvintes, em uma experiência verdadeiramente dialógica. O Memorial da Resistência permite e viabiliza justamente o encontro e diálogo diretos daqueles que vivenciaram as experiências do passado com as novas gerações. Dessa forma, estaria o espaço cumprindo um duplo papel de não somente salvaguardar as lembranças, como acredita Pierre Nora, como também, permitir o encontro e a transmissão "ao vivo" dessas recordações, como se fazia nas sociedades-memória.

Enquanto facilitador de encontros e diálogos, o espaço conjuga o conceito atualmente utilizado de "sítio de consciência", que define as mais variadas formas de organizar e tratar as reconstituições de lembranças de memórias traumáticas, desde a perspectiva dialógica e emancipatória, como define a própria Coalisão Internacional de Sítios de Memória:

[...] lugar de memória - um local histórico, museu de base local ou memorial - que confronta tanto a história que aconteceu no local quanto suas implicações contemporâneas. Destacam a coragem, a crueldade, ou a vida cotidiana através de programas de diálogo público que visam ativar a perspectiva dos sítios históricos,

\footnotetext{
${ }^{212}$ DE VARINE-BOHAN, 2009, p.215.

${ }^{213}$ Entrevista concedida em 08 nov. 2014.
} 
conectando-os com questões que enfrentamos hoje e convidando os visitantes a refletir sobre o papel que eles podem desempenhar na revolução destas questões (NAIDU, 2010, p. 7).

Na perspectiva de tornar-se um espaço que convida e provoca à reflexão, os sítios de consciência se propõem a interpretar a história por meio do local; empreender programas que estimulem o diálogo sobre questões sociais atuais; promover os direitos humanos como valor a ser perseguido; e, por fim, promover o envolvimento público com o local e suas questões. ${ }^{214}$

No caso do Memorial, esses objetivos presentes desde a concepção do projeto museológico e na confecção dos espaços de visitação, se mantêm firmes também na forma do Memorial se relacionar com a comunidade, mantendo a mesma perspectiva de construção coletiva. Mesmo antes de sua inauguração, o grupo de ex-presos foi convidado a participar também das atividades do Memorial. Este foi um momento em que parece, segundo algumas falas, ter havido alguns rompimentos no grupo, de acordo com as recordações de Maurice:

Muita gente se afastou, muitos ex-presos, porque também entre expresos tem muita briga, muita disputa política. Teve uma pessoa conhecidíssima no meio, chegou no dia da inauguração, e falou "olha, para fazer essa porcaria era melhor não ter feito nada." Tem gente que pensa assim. Tem gente que não participa porque é muito sofrimento: "Porque eu não posso ir lá, porque preciso pensar em outra coisa. Vocês ficam cultuando."215

Nesse instante, o narrador quis deixar claro que não há saudosismo nessa participação, nem culto ao sofrimento, ao contrário do que pensavam outros expresos políticos com quem dialogava na época: "Não, nós só fazemos atividades do passado relacionado com o presente. Não é saudosismo. Então nós ficamos. Nós ficamos, porque nós achamos que tivemos sucesso." 216

A ideia de participar efetivamente das atividades do Memorial foi recebida com surpresa pelo grupo, que não conseguiu na ocasião, dimensionar como seria esta atuação no Memorial agora em ação, como recorda o narrador Maurice:

Nunca imaginava que ia ser esse sucesso. Eu pensei que nós expresos que íamos ser os monitores, que íamos explicar para os

\footnotetext{
${ }^{214}$ NAIDU, p. 07

${ }^{215}$ Entrevista concedida em 10 jan. 2015.

${ }^{216}$ Entrevista concedida em 10 jan. 2015.
} 
visitantes. Muitos falavam: "Pôxa, eu vou ter que ficar lá esperando que alguém fosse visitar, e tal." $E$ aí a equipe de museologia falou: "Não, vocês não vão ser os monitores, os monitores são gente jovem, que vai falar. Vocês vão vir como convidados." 217

Uma vez que o convite foi aceito, é possível identificar que há pelo menos três formas de participação do grupo de ex-presos no Memorial da Resistência, indicadas em suas falas: como palestrantes nas atividades promovidas diretamente pela equipe de especialistas do Memorial, por meio de ações educativas que recebem alunos e professores; como parte do conselho consultivo do Memorial, que atua, por exemplo, nas escolhas das exposições temporárias; e na gestão direta de encontros, debates, seminários e todo tipo de atividades de diálogo com a comunidade, como as atividades culturais chamadas "Sábados Resistentes".

É o narrador Maurice que conta como se dá a participação no Conselho Consultivo:

Por exemplo, o Memorial tem um Conselho de educação educativa que é formado por seis, sete pessoas. [...] São seis, sete pessoas da sociedade que se reúnem duas vezes por ano, nomeados pelo Secretário da Cultura, sem remuneração, para orientar a pessoa sobre que tipo de exposição temporária é melhor, discutir orçamento, em fim, fazer uma espécie de patronado. É a gente, o Marlon, o Lauro Ávila, que foi do Arquivo do Estado e pessoas da Prefeitura. O Memorial conta com essa participação. ${ }^{218}$

Por meio desse tipo de participação, o Memorial mantém sob consulta dos ex-presos políticos, ou seja, do próprio grupo social que demanda a existência do Memorial, uma série de questões de relevância para a própria gestão do local. Dessa forma, a participação diz respeito também aos rumos que o Memorial da Resistência pode tomar.

Assim, o Memorial, gestado e gerido por meio da parceria de gestores públicos e da sociedade civil, aqui representada pelo grupo de ex-presos políticos, aproxima-se do ideal de espaço público de participação social evocado desde a Constituição Federal de 1988, como núcleo de um projeto verdadeiramente democratizante. Ao mesmo tempo em que conta com a participação social em instâncias decisórias, como o Conselho Consultivo e os Sábados Resistentes, não

\footnotetext{
217 Entrevista concedida em 10 jan. 2015.

${ }^{218}$ Entrevista concedida em 10 jan. 2015.
} 
transfere totalmente a responsabilização das políticas públicas de memória para a sociedade. Parece haver, de fato, um projeto democratizante participativo de parceria, como defende Evelina Dagnino. ${ }^{219}$

Para dar sustentação a esses mesmos objetivos, o Memorial da Resistência dispõe de um programa museológico estruturado em seis eixos:

O programa museológico do Memorial da Resistência está estruturado em procedimentos de pesquisa, salvaguarda (documentação e conservação) e comunicação patrimoniais (exposição e ação educativo-cultural), orientados para os enfoques temáticos sobre resistência, controle e repressão política, por meio de seis linhas de ação que, atuando articuladamente, têm como objetivo fazer dessa instituição um espaço voltado à reflexão e que promova ações que contribuam para o exercício da cidadania, o aprimoramento da democracia e a valorização de uma cultura em direitos humanos: Centro de Referência, Lugares de Memória, Coleta Regular de Testemunhos, Exposição, Ação Educativa e Ação Cultural. ${ }^{220}$

As três primeiras vertentes de atuação, que são o Centro de Referência, Lugares de Memória e Coleta Regular de Testemunhos, se inserem na lógica da formação e compartilhamento de acervos e informações, com um viés voltado à pesquisa.

No sentido de conservar um espaço de convergências dos aportes gerados pelas demais ações programáticas do Memorial, o Centro de Referência é um espaço de pesquisa que visa ampliar o conhecimento, principalmente, voltado ao público de jovens estudantes. Congrega material cultural e educativo produzido pelo próprio Memorial, uma biblioteca púbica e o resultado das diversas atividades do espaço. ${ }^{221}$

Com caráter preservacionista, o programa "Lugares de Memória" busca identificar e inventariar locais que fazem parte dos acontecimentos marcantes da resistência e da repressão, levando até esses espaços os princípios de preservação da memória. Atualmente já são mais de 200 lugares mapeados pelo

\footnotetext{
${ }^{219}$ DAGNINO, 2004. p 97

${ }^{220}$ Disponível em:

$<$ http://www.memorialdaresistenciasp.org.br/memorial/default.aspx?c=entrevistados\&mn=8.> . Acesso em: 06 jun. 2015.

${ }^{221}$ Mais informações disponíveis em:

$<$ http://www.memorialdaresistenciasp.org.br/memorial/default.aspx?mn=44\&c=0\&s=10.>. Acesso em: 20 jun. 2015.
} 
projeto $^{222}$ que se fundamenta na seguinte ideia:

O (re)conhecimento desses lugares pode ser um importante
instrumento de educação para a cidadania, uma vez que aproxima
os fatos que ocorreram no passado com as permanências no
presente. No entanto, é necessário que esses lugares, suportes de
informação, sejam tratados sob uma perspectiva museológica, com
a aplicação de procedimentos técnicos e científicos da cadeia
operatória museológica, ou seja, de pesquisa, salvaguarda e
comunicação patrimoniais.

A Coleta Regular de Testemunhos, visando ampliar o acervo de narrativas sobre a história do DEOPS/SP e da ditadura, registra testemunhos de ex-presos, perseguidos políticos, familiares e ex-funcionários da instituição, mantendo um canal aberto de comunicação para que aqueles que queiram registrar suas impressões e lembranças possam encontrar esse espaço no Memorial. O aporte que surge dessa atividade fornece constantemente novos subsídios às demais ações do Memorial, possibilitando novas escolhas para a exposição de longa duração, as mostras temporárias, material educativo e ações culturais. ${ }^{224}$ Atualmente, o projeto conta com 106 entrevistas realizadas. ${ }^{225}$

Essas três linhas de atuação não surgem nas lembranças dos narradores, indicando que sejam gerenciadas e executadas totalmente pelos profissionais do Memorial. Da análise das narrativas, conclui-se, no entanto, que a atuação do grupo de ex-presos se dá mais diretamente por meio das ações: educativa, cultural e expositiva.

As duas primeiras são aquelas em que se efetivam o contato direto e o diálogo com a comunidade e por meio das quais o grupo de ex-presos mais atua. Também a "Ação Exposição" merece ser trabalhada como eixo que sofre influência direta da atuação dos ex-presos, em razão da participação direta do grupo na estruturação do projeto museológico, bem como da própria montagem e construção

\footnotetext{
${ }^{222}$ Questionário eletrônico respondido por Kátia Filipini em 22 de julho de 2015.

${ }^{223}$ Disponível em:

$<$ http://www.memorialdaresistenciasp.org.br/memorial/default.aspx?mn=9\&c=136\&s=0. $>$. Acesso em: 20 jun. 2015.

${ }^{224}$ Mais informação disponível em:<http://www.memorialdaresistenciasp.org.br/memorial/default.aspx?mn=8\&c=135\&s=0.> . Acesso em: 20 jun. 2015.

${ }^{225}$ Questionário eletrônico respondido por Kátia Filipini em 22 de julho de 2015.
} 
de alguns espaços, como se verá no próximo tópico.

Inicialmente, a Ação Educativa tem como uma de suas proposições o conceito de educação enquanto constante processo reflexivo sobre as práticas do cotidiano, tendo como princípio a preservação e a afirmação da dignidade humana.

Esta linha programática foi pensada de modo a interagir diretamente com profissionais da área da educação e turismo, bem como estudantes, de modo a levar para além das paredes do Memorial os seus conceitos e significados. Leva, ainda, em consideração, os diferentes grupos de visitantes, que vão desde "universidade, faculdades, cursos técnicos, instituições de ensino não formal e grupos de terceira idade, portadores de necessidades especiais e moradores do entorno." 226

A educação em direitos humanos tem sido objeto de intensos e recentes debates no Brasil. O Plano Nacional de Educação em Direitos Humanos IIII, em 2010, apresentou diversas diretrizes que promovam a inserção dos direitos humanos nas práticas de ensino, em diversos níveis, de modo a fortalecer os princípios da democracia e uma cultura de direitos. ${ }^{227}$

Outro eixo do PNDH 3 voltado, especialmente, para o Direito à Memória e à Verdade, também traz diversas ações programáticas para a promoção da memória, entre elas, a diretriz de "desenvolver programas e ações educativas, inclusive, a produção de material didático-pedagógico para ser utilizado pelos sistemas de educação básica e superior sobre graves violações de direitos humanos". ${ }^{228}$

Relatório Final da Comissão Nacional da Verdade, em 2014, aponta em áreas suas recomendações finais, a necessidade de reformulações curriculares, que visem igualmente "valorizar o conhecimento sobre os preceitos inerentes à democracia e aos direitos humanos", especialmente, junto aos cursos de formação das Forças Armadas, órgãos de segurança e academias militares e policiais. ${ }^{229}$

O Memorial segue, assim, em consonância com as discussões mais contemporâneas na área da educação e, para dar efetividade a essa linha de

\footnotetext{
${ }^{226}$ Idem, p. 146

227 Brasil. Secretaria de Direitos Humanos da Presidência da República. Programa Nacional de Direitos Humanos (PNDH-3) / Secretaria Especial dos Direitos Humanos da Presidência da República.ver. e atual. - Brasília: SEDH/PR, 2010. p. 185.

228 Brasil, 2010. p. 216.

${ }^{229}$ Relatório CNV, p. 967.
} 
atuação, realiza momentos de encontro com professores e alunos, distribui material de auxílio que possa ser trabalhado em sala de aula, a partir dos referenciais apresentados nas exposições do Memorial. Se propõe, assim, a expandir os princípios do Memorial para junto da comunidade, principalmente, entre os jovens, tornando o espaço museológico um potencial lugar de transformação social, para além de mero reprodutor de conhecimento e informação. ${ }^{230}$

Essa prática que se pretende chegar ao seio da comunidade com as reflexões iniciadas por meio dos aportes do Memorial surge na fala da narradora Elza, também educadora

Se você, nas escolas, conseguir envolver, principalmente, os professores de história... (...) eles devem estar envolvidos. Nesse sentido, uma das coisas bem marcantes é essa caminhada lá embaixo (nas exposições), onde as pessoas podem ver a história do prédio e quem vivia aqui. ${ }^{231}$

A narradora parece ter consciência de que o processo de expansão do debate acerca das violações de direitos humanos praticadas pelo Estado, debate a que se propõe o Memorial, deve extrapolar as suas paredes. Para ela, sua atuação neste sentido, assim como a dos demais ex-presos políticos, é de contribuir para que isto aconteça:

A gente acha que nos currículos dos cursos deveria realmente ter formalmente um período mais forte de resgate do que aconteceu no país. Tem algumas faculdades que têm feito isso, outras menos. A gente tem procurado estimular, incentivar, para que enquanto a gente estiver por aqui não perca o rumo da nossa caminhada. ${ }^{232}$

O diálogo entre o discurso da exposição e os diferentes perfis de público, segue em constantes e periódicos encontros com alunos, educadores e professores, por meio das diversas atividades que compõem o eixo educativo. 0 trabalho da linha educativa é pensado e projetado por profissionais da área da educação que atuam também como mediadores junto aos visitantes.

A linha educativa desenvolve, as seguintes atividades: visitas educativas, por meio das quais o Memorial recebe estudantes da rede pública e privada de

\footnotetext{
${ }^{230}$ BRUNO, 2009, p.47.

${ }^{231}$ Entrevista concedida em 08 nov. 2014.

${ }^{232}$ Entrevista concedida em 08 nov. 2014.
} 
ensino para visitação mediada por educadores profissionais no espaço; encontros com educadores, professores de diversas áreas, guias turísticos e estudantes onde são trabalhados mais profundamente o papel do DEOPS/SP, os conceitos de repressão e resistência e, também, o material pedagógico de apoio ao professor, com o objetivo de auxiliar o trabalho desses profissionais fora do Memorial; da mesma forma voltado aos profissionais da área da educação e do turismo, além de estudantes, são realizadas palestras com diferentes profissionais de modo a aprofundar alguns temas específicos da Era Vargas e do regime instaurado com o golpe de 1964; curso intensivo de "Educação em Direitos Humanos - Memória e Cidadania" 233 ; 0 projeto "Conhecendo o DEOPS/SP: História e Memória"234; Contação de Histórias voltada ao público infantil na apresentação dos conceitos e conteúdos do Memorial; o programa "Memorial Para Todos", que promove visitas educativas, em especial, voltadas para públicos com deficiência, contando com a utilização de material que torne acessível a compreensão do edifício e de suas temáticas; e a produção de materiais de apoio pedagógico para ser utilizado pelos educadores em sala de aula.

Também parte da linha programática, a atividade denominada "Rodas de Conversa" foi projetada de modo a integrar os profissionais de educação que atuam no Memorial com os ex-presos políticos em atividades voltadas para os profissionais de educação e estudantes:

Rodas de Conversa com ex-presos políticos: proporcionam uma

\footnotetext{
233 "O curso tem por objetivo promover, numa perspectiva multiplicadora, a aprendizagem de conhecimentos específicos, a troca de experiências, a reflexão crítica e a elaboração de projetos educativos no âmbito da Educação em Direitos Humanos (EDH). Sua proposta parte da premissa de que a EDH se compromete com a mudança social em nível de percepções, atitudes e relações, e da perspectiva interdisciplinar e multidimensional entre direitos humanos, conhecimento e realidade, reservando ao papel dos educadores uma responsabilidade central nesse processo. Realizado uma vez ao ano." Disponível em: <http://www.memorialdaresistenciasp.org.br/memorial/default.aspx?mn=12\&c=81\&s=0> Acesso em: 20 jun. 2015.

234 "Realizado em parceria com o Núcleo de Ação Educativa do Arquivo Público do Estado, este projeto se propõe a discutir sobre a atuação do Departamento Estadual de Ordem Política e Social de São Paulo - DEOPS/SP e das manifestações de resistência política da sociedade em oposição ao Estado Novo e ao regime militar. A atividade busca integrar os potenciais educativos do acervo documental do DEOPS/SP e da exposição de longa duração do Memorial. Voltada para grupos de alunos de Ensino Fundamental, Médio e Superior (graduação e pós-graduação universitária), além de grupos de professores, a programação conta com palestra sobre o DEOPS/SP e visita educativa ao Memorial da Resistência. Realizado mensalmente." Disponível em: $<$ http://www.memorialdaresistenciasp.org.br/memorial/default.aspx?mn=12\&c=81\&s=0.> Acesso em: 20 jun. 2015.
} 
experiência educativa de diálogo com ex-presos políticos, que resistiram contra a ditadura militar e estiveram presos no DEOPS/SP. A atividade se desenvolve em dois momentos: a visita educativa ao Memorial da Resistência, acompanhada pelos educadores, e a conversa com um ex-preso político convidado, que compartilha sua experiência pessoal de militância política. É voltado a grupos de alunos do Ensino Médio e Superior, além de grupos de professores e projetos sociais, entre outros. Realizadas conforme a demanda. ${ }^{235}$

Nesses encontros, a atuação integrada entre mediadores profissionais e o grupo de ex-presos, integra técnicas educativas com o diálogo aberto na troca de experiências entre passado, presente e futuro. A participação do grupo que viveu naquele espaço e vivenciou as experiências do DEOPS e da ditadura surge como importante fator propulsor da reflexão política a que se propõe o Memorial da Resistência, de modo a enriquecer a percepção do visitante a partir da personificação das histórias narradas nas exposições. ${ }^{236}$

Os ex-presos dialogam diretamente com o público de professores e alunos, ou seja, de possíveis multiplicadores que poderão levar o Memorial para junto da comunidade, demonstrando a atenção com uma educação transformadora, focada no debate político e no diálogo crítico. Essas são as mesmas bases da educação recebida pela narradora Elza, às quais atribui, inclusive, sua "caminhada na luta pelos direitos humanos." A experiência em uma escola politizada parece ser a justificativa da narradora para seu posterior envolvimento com a educação voltada às classes populares e com a erradicação do analfabetismo. A militância nessa seara se deu ainda durante a militância estudantil, logo no início da ditadura e, mais tarde, após sua libertação, durante o autoexílio em diversos países:

[...] quando a gente começou com todo o trabalho de alfabetização, o movimento de alfabetização de adultos que foi, na minha geração, um marco muito importante, porque a gente começou a fazer com que os jovens participassem. Nós tivemos uma presença muito forte de juntar alguns setores. Juntar o SESC com a Folha de São Paulo e fazer um evento grande no litoral, em Ubatuba, levando os jovens de diferentes escolas para participarem desses

235

Disponível

em: http://www.memorialdaresistenciasp.org.br/memorial/default.aspx?mn=12\&c=81\&s=0. Acesso em: 22/06/2015.

${ }^{236}$ ARAÚJO, Marcelo Mattos. [et al.] O Memorial em Ação. Memorial da Resistência de São Paulo I textos, concepção e coordenação geral Marcelo Mattos Araújo e Maria Cristina Oliveira Bruno; textos de Kátia Felipini Neves [et al.] São Paulo: Pinacoteca do Estado, 2009. p.143. 
grupos de alfabetização. Fomos quase em torno de 200 alunos para lá dar o curso de alfabetização, para fazer um trabalho muito intenso, mesmo já começando o período autoritário, em torno de 1964, 1965. [...] Estava muito ligada ainda ao pessoal de alfabetização de outros países e da UNESCO. Fui fazer um trabalho em outros países: fiquei um tempo na Argentina, um tempo no Chile, outro tempo no Peru. Depois acabei indo para Paris e fiquei na sede do Comitê Coordenador Internacional de Serviço Voluntário, onde também se fazia atividades com diferentes grupos, fazendo discussões sobre a realidade dos mais diversos países. Foi sempre uma caminhada de envolvimento com as realidades locais. ${ }^{237}$

A experiência pessoal da educação na rede pública a qual a narradora teve acesso, como estudante, surge em sua fala como um privilégio de uma geração. Traz muitos detalhes dos tempos da escola em suas recordações, de momentos lúdicos como campeonatos temáticos de geografia, concursos de verbo ou aula de francês que davam doces como prêmios, a mergulho em temas políticos como a leitura de "Geografia da Fome", de Josué de Castro. O envolvimento dos profissionais dedicados e os debates interdisciplinares como métodos constantes, são lembrados pela narradora com alegria e satisfação:

O colégio em Pinheiros, Colégio Estadual Fernão Dias Paes, foi uma grande formação na minha época. Não temos mais colégios com esse perfil de envolvimento dos profissionais como naquela época. Eu resgato isso, porque acho que é importante a gente ter uma memória do passado. [...] Naquele momento a gente tinha um envolvimento muito forte dos professores, profissionais que se dedicavam inteiramente à formação dos alunos[...]. Realmente o colégio foi muito marcante na nossa formação. E os debates eram constantes, porque os professores entre si se articulavam. Não era uma coisa isolada. Eram pessoas que estavam formando esses alunos. Me sinto privilegiada de ter vivenciado essa caminhada. ${ }^{238}$

A narradora parece creditar a esta sua experiência a crença na educação como mecanismo de transformação social, uma convicção que parece carregar ainda nos dias atuais:

Esse foi um caminhar que na minha geração é o resgate que a gente faz de ter sido privilegiado tanto em relação à área colegial como depois na parte de faculdade. Isso fez com que se caminhasse sempre com a preocupação que se tinha que estar

\footnotetext{
${ }^{237}$ Entrevista concedida em 08 nov. 2014.

${ }^{238}$ Entrevista concedida em 08 nov. 2014.
} 
transformando a realidade. ${ }^{239}$

Com o passar dos últimos anos, em atenção a esta diversidade de demandas, essas atividades sofreram várias transformações, de modo que se nota a preocupação em aperfeiçoar constantemente a atividade, conforme os resultados das medições de impacto no público, de modo a refletir as necessidades do público. Assim, metodologias, dinâmicas, roteiros e materiais são constantemente adaptados ou substituídos.

Há a preocupação em tornar o lugar um espaço com público cativo, onde o mesmo visitante sinta desejo de retornar várias vezes, de modo a fazer parte de sua referência como espaço de estudos, diálogos e debates, de modo a justificar a necessidade do Memorial estar afinado com os anseios da comunidade com quem busca o diálogo. Maurice Politi aponta algumas mudanças já projetadas para o espaço, com o objetivo de manter a comunidade desejosa em estar presente no Memorial da Resistência:

Agora vai mudar. Não sei se te falaram isso? Vai mudar a exposição de longa duração, porque os museólogos dizem que se uma pessoa veio uma vez, duas vezes, nunca mais. Aquele negócio de ouvir depoimento vai ficar. Vaiter outras. Você consegue trazer aquele público para escutar outras histórias. ${ }^{240}$

A preocupação em manter-se num espaço sempre em conexão com a comunidade surge novamente na fala de Maurice, ao justificar a necessidade de alterar algumas referências pensadas no projeto museológico inicial, considerando que não suprem mais as expectativas e necessidades da comunidade:

Mas tem outras celas, por exemplo, aquela que tem os vídeos dos mortos, aquela vai mudar. Aquele lugar que é o Centro de Referência onde ficam os dois computadores a gente viu que não é eficiente. A pessoa acabou de visitar a cela não quer mais entrar ali, sabe? Eles estão tão impactados. Ali a gente pensou no início: "Não, tem que ter um lugar porque as pessoas vão querer saber mais. Então põe dois computadores com internet e ela entra nos lugares de memória no Chile ou "quero saber mais sobre a ditadura”, então entro no Brasil Nunca Mais." Mas o pessoal não faz. Então é um espaço perdido que vai remodelado. Vai ser uma remodelação que nós discutimos, nós também somos partícipes dessa remodelação.

\footnotetext{
${ }^{239}$ Entrevista concedida em 08 nov. 2014.

${ }^{240}$ Entrevista concedida em 10 jan. 2015.
} 
Estas conclusões são fruto não só dos encontros entre agentes públicos e ex-presos políticos. O Memorial mantém constante diálogo com a comunidade no sentido de diagnosticar aquilo que está ou não cumprindo sua missão. São realizadas avaliações tanto em pesquisas formais de público como também por meio de filipetas e dos livros de visitas, preenchidos pelos visitantes. Segundo Katia Filipini, "o retorno é muito positivo", o que a leva a crer que o "o Memorial é bastante exitoso."241

Partindo para o segundo eixo de atuação que conta com a participação direta do grupo de ex-presos políticos, a Ação Cultural lança mão de práticas que promovem os temas relacionados às violações e à resistência à ditadura por meio de encontros mais amplos com a comunidade, na forma de seminários, encontros, palestras, lançamentos de filmes e livros, por meio das seguintes atividades:

Cinema da Resistência - o projeto Cinema da Resistência tem como objetivo utilizar o potencial das diferentes manifestações artísticas para abordar os principais temas trabalhados pela Instituição - repressão e resistência políticas e direitos humanos. Consiste na exibição de filmes, seguida de debate com diretor e ou colaborador para sua realização. Realizado como piloto, a partir de 2016 deverá ser realizado no mês de fevereiro, uma vez por semana.

Semana Nacional de Museus: participação do Programa da Semana Nacional de Museus do Instituto Brasileiro de Museus IBRAM/MinC, por meio da realização de atividades como palestras, seminários, oficinas, etc. de acordo com os temas propostos pelo Programa. Realizado uma vez por ano, no mês de maio.

Primavera dos Museus: participação do Programa da Semana Nacional de Museus do Instituto Brasileiro de Museus IBRAM/MinC, por meio da realização de atividades como palestras, seminários, oficinas etc. de acordo com os temas propostos pelo Programa. Realizado uma vez por ano, no mês de setembro.

Projetos multimídia/intervenções artísticas: ações conjuntas com a Pinacoteca do Estado, especialmente, na intervenção artística no muro externo (estacionamento) no âmbito da Virada Cultural. Também está previsto lançamento de edital para projetos multimídia e intervenções artísticas em formatos diversos.

Apoio a propostas externas: apoio à realização de atividades propostas por instituições e outros grupos. Com os Sábados Resistentes, realiza em torno de 25 atividades por ano. ${ }^{242}$

\footnotetext{
${ }^{241}$ Questionário eletrônico respondido por Kátia Filipini em 26 de julho de 2015.

242 Disponível em:

<http://www.memorialdaresistenciasp.org.br/memorial/default.aspx?mn=13\&c=74\&s=0. $>$ Acesso em: 18 abr. 2015.
} 
As atividades culturais foram desenvolvidas e executadas ainda antes da inauguração do Memorial da Resistência, no ano de 2008. Foi também nessa época que alguns ex-presos políticos decidiram mais que participar do projeto museológico e cobraram do Estado o uso direto do espaço, de modo que os permitisse gerir com autonomia algumas atividades. A ideia parecia bem ousada, segundo as lembranças de Ivan:

Como a gente construiu uma relação extremamente leal do Governo conosco, nós dissemos "olha, nós queremos uma contrapartida, não estamos recebendo um centavo para fazer isso, nós queremos o direito de fazer atos políticos aqui dentro." "Como assim?" "Não, não é ato contra esse ou aquele partido, mas é sobre a história. A nossa marca é: nós queremos homenagear os que tombaram, glorificar os atos heroicos, denunciar os atos canalhas do passado, para gente fazer um pé no presente." "Tudo bem". ${ }^{243}$

Dessa negociação com os agentes públicos responsáveis pelo Memorial, nasceu o projeto "Sábados Resistentes", o qual trata-se de "um conjunto de atividades que busca debater questões sociopolíticas do passado e atuais por meio de diferentes formatos, tais como palestras, lançamento de livros, apresentação de filmes e peças de teatro". 244

Segundo as narrativas de Ivan e Maurice, é possível identificar que nesse momento que antecedeu a inauguração do Memorial havia para eles a percepção de um conjunto de fatores positivos a influenciar a pauta da memória política: o sucesso da reivindicação do prédio do antigo DEOPS, estampado no exitoso projeto museológico do Memorial da Resistência; a introdução e expansão do tema da justiça de transição no Brasil, convergindo diversos órgãos e entidades; a estabilidade da pauta da reparação às vítimas; e, agora, a concreta possibilidade de poder ocupar diretamente um espaço com atividades voltadas à promoção da memória, por meio dos "Sábados Resistentes".

Embora a ideia não fosse unanimidade entre os membros do Fórum de expresos, um grupo estava decidido a ampliar substancialmente a atuação na

\footnotetext{
${ }^{243}$ Entrevista concedida em 08 nov. 2014.

${ }^{244}$ Informações disponíveis em:

$<\mathrm{http}: / / \mathrm{www}$.memorialdaresistenciasp.org.br/memorial/default.aspx?mn=13\&c=74\&s=0.> Acesso em: 20 jun. 2015.
} 
promoção da memória. Nasceu, assim, das discussões no interior do Fórum, a entidade "Núcleo de Preservação da Memória", ou "Núcleo Memória", como recorda Ivan:

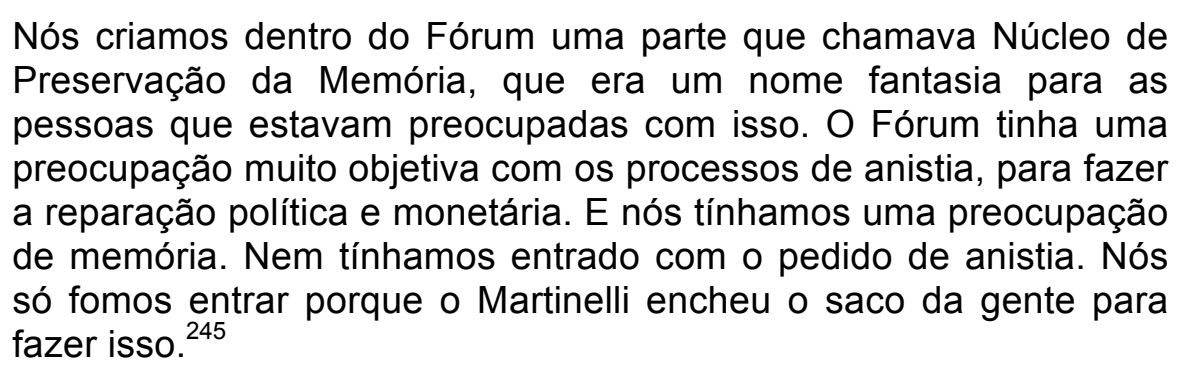

Nesse momento das falas, surgem indicativos de que já havia algumas divergências internas no Fórum em relação a atuar com a pauta da memória. Maurice Politi atribui também a isso a necessidade de criar uma outra entidade que suprisse, então, o anseio desse grupo, que estava determinado a ampliar a pauta da memória política: "como vimos que a gente atuava muito melhor em um grupo pequeno que em um grande com pessoas com várias tendências políticas, a gente construiu o Núcleo Memória."246

Foram os narradores Ivan e Maurice que tomaram a frente na criação do Núcleo, sendo seus membros fundadores. Anistiados políticos pela Lei de Anistia $n^{\circ} 10.559 / 2002$, utilizaram o valor de suas reparações econômicas para a criação da entidade. Atualmente, Ivan faz parte do Conselho de Administração do Núcleo, mas em razão de sua saída da cidade de São Paulo, no ano de 2015, encontra-se afastados de suas atividades mais rotineiras. ${ }^{247}$ Maurice, foi presidente da entidade entre os anos de 2009 e 2011 e, atualmente, é Diretor Administrativo do Núcleo, eleito para o mandato de 2014 a 2017. Participa intensamente das atividades promovidas pela entidade, como organizador, convidado e palestrante. ${ }^{248}$

Elza também integra a Diretoria do Núcleo Memória e participa com frequência da organização de suas atividades e, também, como "palestrante nas rodas de debates com os estudantes das escolas públicas da Cidade de São

\footnotetext{
${ }^{245}$ Entrevista concedida em 08 nov. 2014.

${ }^{246}$ Entrevista concedida em 10 jan. 2015.

${ }^{247}$ Questionário enviado em 02 jun. 2015.

${ }^{248}$ Questionário enviado em 02 jun. 2015.
} 
Paulo, bem como em rodas em Bibliotecas Públicas da Cidade de São Paulo." 249

Sob o lema "conhecer o passado, para entender o presente e construir o futuro", o "Núcleo Memória" surge vocacionado a dedicar-se à promoção e difusão da memória, ampliando meios de conscientização sobre as violações praticadas e a resistência política:

O Núcleo Memória tornou-se uma instituição independente a partir de fevereiro de 2009. Suas atividades consistem na promoção de políticas públicas nas questões referentes à Memória Política, na defesa dos Direitos Humanos e em ações educativas nessas áreas. Em conjunto com outras entidades similares no Brasil e na América Latina, promove a conscientização dos organismos públicos e privados para transformar em memoriais de referência os lugares onde ocorreram violações dos direitos humanos. [...] Em 2009, o Núcleo Memória tornou-se o primeiro membro institucional brasileiro da Coalizão Internacional de Lugares de Consciência. ${ }^{250}$

O Núcleo revestiu de profissionalismo a atuação do grupo de ex-presos na promoção da memória. Conforme Maurice Politi,

essa entidade, o Núcleo Memória, tem relações mais profissionais com o Memorial, temos um contrato com o Memorial. E a gente presta assessoria e a gente recebe uma ajuda de custo. O Núcleo recebe. Que permite a gente manter a sala permite, se alguém precisa vir para um Sábado Resistente, que a gente pague a passagem, o hotel. Esse dinheiro serve para isso. $E$ tem funcionado muito bem desde 2009. Nosso primeiro contrato com o Memorial foi em 2009. ${ }^{251}$

Foi assim que, ainda em 2009, o Núcleo Memória passou a integrar a Rede Latino-Americana de Lugares de Memória e Consciência, uma rede que reúne mais de vinte entidades de onze países da região voltadas à promoção da memória das violações de direitos humanos das ditaduras. Sendo o primeiro representante do Brasil na Rede, posteriormente, foi acompanhado do próprio Memorial, como relembra Maurice:

Por isso então que nós fomos os primeiros (a ingressar na Coalisão) e o segundo é o Memorial, porque quando a gente se associou à Rede da Coalisão Internacional, logo em seguida inaugurou o Memorial. E aí o Memorial também é parte, por isso

\footnotetext{
${ }^{249}$ Quentionário enviado em 10 jan. 2015.

${ }^{250}$ Detalhes do Núcleo disponível em <http://www.nucleomemoria.org.br/conhecal.> Acesso em: 19 mar. 2015.

${ }^{251}$ Entrevista concedida em 10 jan. 2015.
} 
que até agora só esses dois organismos fazem parte..$^{252}$

Como parte da Rede, o Núcleo Memória integra também, a Coalisão Internacional de Sítios de Consciência, rede internacional que reúne sítios históricos, atores e iniciativas de memória, com mais de cento e oitenta membros em todo o mundo. Sua atuação conjunta visa divulgar, encorajar e estimular a memória das violações de direitos humanos e de resistência política, promovendo o uso de lugares como condutores para a concepção e consolidação da democracia. ${ }^{253}$

A ligação de Maurice Politi com o Núcleo Memória denota um envolvimento de fato muito intenso e é ele quem mais trouxe informações sobre a entidade. A simples escolha do nome, por exemplo, ao ser recordada por ele, remonta sua própria história de vida desde o exílio, até o casamento com uma perseguida política argentina e a amizade com grupos de ex-presos políticos argentinos: o tempo do exílio em Israel o levou a conhecer sua ex-esposa, uma argentina também exilada e a passagem posterior pela Argentina onde viveu por sete anos e conheceu o pessoal da "Rede", em referência à Rede Latino- Americana da Coalizão Internacional de Lugares de Consciência e Memória.

Foi no contato com a "Memoria Abierta", entidade argentina participante da Rede, Maurice recorda que chegou a propor criar no Brasil uma entidade chamada "Memória Aberta":

Eu fui para a Argentina e eu falei com a então presidente do Memoria Abierta: "Pronto, nós vamos formar uma entidade no Brasil e nós vamos chamar Memória Aberta." Só que ela não deixou (risos). Ela falou: "Não, vocês criem outro nome. Vocês sempre vão ser nossos parceiros, mas não quero o mesmo nome." Foi até bom. Mas a ideia era seguir os moldes deles. Eles são muito bons estão há anos luz do que a gente é. Mesmo depois de muitos anos, lá tem uma estrutura muito grande. Nós formamos uma estrutura pequena. ${ }^{254}$

Com o passar dos anos, o Núcleo Memória expandiu sua atuação para além

\footnotetext{
${ }^{252}$ Entrevista concedida em 10 jan. 2015.

${ }^{253}$ Disponível em: <http://www.sitesofconscience.org/es/sobre-la-coalicion/.>Além do Brasil, fazem parte da Rede e da Coalisão, Argentina, Chile, Equador, El Salvador, Guatemala, Paraguai, Peru, República Dominicana e Uruguai. Disponível em: <http://www.memoriaabierta.org.ar.>

${ }^{254}$ Entrevista concedida em 10 jan. 2015.
} 
das atividades do Memorial e hoje atua em diversas frentes de memorialização de diversos espaços na cidade de São Paulo. O sentido de ampliar este mapa da memória da repressão e da resistência políticas surge para Maurice como a necessidade de um "roteiro da memória." Em sua fala, deixa transparecer a intenção de participar de um amplo processo de redesenho de São Paulo a partir das recordações de todas essas experiências:

A ideia é essa, que tenhamos em São Paulo, como tem em Paris, o roteiro da memória. E aí a pessoa visita ao DOI-CODI, ao DOPS e à Auditoria, que são os três lugares. Se tivesse o Presídio Tiradentes a gente tombaria o Presídio Tiradentes para ser um quarto lugar. ${ }^{255}$

Um novo e desafiador projeto de memorial na cidade de São Paulo está em andamento e conta com a participação do Núcleo Memória. Ex-sede de uma das divisões mais sangrentas da repressão política, o prédio que foi ocupado pelo Destacamento de Operações de Informações - Centro de Operações de Defesa Interna - DOI-CODI, na Rua Tutóia, bairro de Vila Mariana, já teve seu tombamento efetivado por iniciativa do Núcleo:

E vamos conseguir o DOI-CODI também. DOI- CODI na Rua Tutóia, já foi tombado. E isso foi iniciativa nossa do Núcleo. O Ivan, porque não podia ser a entidade. "Tá, tudo bem, o DOPS está aí, mas e o DOI-CODI?" O Ivan assina a petição como amicus curiae. Fica três anos até que o Marcelo Araújo assume a Secretaria e retoma o processo, até que o lugar é tombado. ${ }^{256}$

Atualmente sede de uma delegacia de polícia de bairro de classe média alta, Maurice destaca a resistência da população local na criação de um memorial:

O problema é que ele é tombado, mas é da Secretaria de Segurança e lá é uma delegacia. [...] Teve um abaixo assinado de mais de sete mil assinaturas da vizinhança alegando que aqui tem muito problema de segurança. [...]O DOI-CODI vai ser mais difícil, porque implica em uma decisão política de uma Secretaria para outra, sendo que é na Vila Mariana, na Rua Tutóia, bairro de classe média e o pessoal, os residentes, não querem que a Delegacia saia. ${ }^{257}$

A resistência da comunidade local é avaliada pelo narrador não como um

\footnotetext{
${ }^{255}$ Entrevista concedida em 10 jan. 2015.

${ }^{256}$ Entrevista concedida em 10 jan. 2015.

${ }^{257}$ Entrevista concedida em 10 jan. 2015.
} 
obstáculo ao projeto. Na sua visão, manter a delegacia no mesmo local do novo memorial, não é o ideal. Mas não será esse o impeditivo se esse for o ponto inegociável com a comunidade. Para ele, o mais importante é a preservação do espaço onde eram praticadas as torturas. Recorda um exemplo na Argentina e conclui que essa pode ser, inclusive, uma boa oportunidade de reflexão com a comunidade sobre o reposicionamento das relações entre as instituições policiais e a prática dos direitos humanos:

Tudo bem, deixa a delegacia em outro lugar. No limite, essa já é uma posição minha, como é na Argentina, que até funcione a delegacia ali. O importante é que o prédio da tortura está intacto. Esse prédio que a gente quer. Claro que não é legal ter a delegacia junto, mas no limite, se precisar, é até legal falar: "Olha, antigamente a delegacia servia para violar os direitos humanos, agora a delegacia serve para proteger a memória." 258

É também Maurice Politi que discorre sobre outra parceria já realizada pelo Núcleo Memória para a formação de mais um memorial em espaço também utilizado pela repressão na cidade de São Paulo, em referência ao prédio, que foi sede da Auditoria Militar:

O que o governo tinha se comprometido era passar o prédio da Secretaria de Segurança para a Secretaria de Cultura. É um prédio do governo federal, não tem nada a ver com o governo estadual. Ele foi cedido em comodato à $O A B$ que tem um termo de parceria com o Núcleo, para gerenciar, e ali vai ser, a hora que tiver grana, vai tocar. ${ }^{259}$

O prédio, localizado à Avenida Brigadeiro Luiz Antonio, $n^{\circ}$. 1.249, será transformado no "Memorial da Luta pela Justiça - Advogados Brasileiros contra a Ditadura". Esse é o local que, segundo as recordações de Maurice, mais o provoca lembranças de dor, dentre os tantos locais pelos quais esteve preso. Ainda assim, foi Maurice Politi que esteve presente na tomada simbólica do prédio, em agosto de 2013, ocasião em que se formalizou publicamente a cessão do espaço à entidade Núcleo Memória. O local abrigou o Tribunal Militar de São Paulo para onde os presos políticos eram levados para prestar depoimentos e ouvir suas sentenças.

Mesmo não tendo sido torturado naquele local, é de sua passagem pela

\footnotetext{
${ }^{258}$ Entrevista concedida em 10 jan. 2015.

${ }^{259}$ Entrevista concedida em 10 jan. 2015.
} 
Auditoria que Maurice guarda um de seus momentos de maior sofrimento durante os anos de cárcere, ao presenciar a dor de sua mãe:

\begin{abstract}
Eu tive muito mais problema de lembrar da Auditoria. E lá eu também não fui torturado. Lá eu lembrava do dia do meu julgamento. Sabe, eu lembro da cena do dia do meu julgamento. Meu advogado tinha garantido à minha mãe que eu ia sair. Eu tinha dois anos presos e ia ser no máximo quatro anos. E para minha mãe, que faleceu e sempre foi muito próxima a mim, o advogado disse "Pena máxima de quatro anos, ele fica em liberdade condicional porque ele já tem dois. Se tivesse com a pena mínima já saia da auditoria, nem volta para a prisão." E aí os caras decidem me enquadrar em outro artigo e me dar dez anos. Quando então me veio naquela sala e eu tô lá e olhei para trás e minha mãe estava lá. Sabe, eu vi ela desfalecendo. Então aquilo até hoje eu lembro. ${ }^{260}$
\end{abstract}

Os frutos do trabalho realizados pelo "Núcleo Memória no Memorial da Resistência" tem alcançado outros grupos de ex-presos e militantes em outros estados. São pessoas que vêm de outras cidades e querem levar esta mesma dinâmica para outras localidades. É o narrador Ivan que lembra, achando graça, dos pedidos para realizarem Sábados Resistentes:

Mas o pessoal aqui de São Paulo é muito engraçado. Uma faculdade de Campinas me pediu para realizar um Sábado Resistente numa terça-feira. Eu falei: "Sábado Resistente tem que ser no sábado, pô" (risos). "Ah, mas a gente não tem aula no sábado." "Então tá bom." Então, assim, criou uma dinâmica em que as pessoas vêm, assistem e dali saem coisas maravilhosas. ${ }^{261}$

Ainda que não seja por parceria formal, a entidade costuma ser muito consultada por outros grupos, conforme destaca Politi. Como exemplo, cita dois casos em outros estados que estão recebendo apoio do Núcleo, um em Pernambuco e outro na Bahia, deixando claro em sua fala, que possui expectativas de ainda mais ampliação em trabalhos desse tipo:

Pernambuco a gente foi lá várias vezes, eu fui lá. Apresentamos nosso
trabalho e ele tem lá agora o Memorial no prédio que era do DOPS, mas
tem a Secretaria de Direitos Humanos trabalhando lá e eles querem fazer
o Memorial no mesmo local. Atuamos também muito com o Carlinhos
Marighella, filho do Carlos Marighella, para o tombamento da casa. Mas
não é parceria formal, porque o Núcleo é uma entidade pequena. Com (o
prédio) da Auditoria que Núcleo vai desabrochar. Aí vai ter mais recurso,
mais gente para trabalhar e fazer um trabalho similar ao trabalho que está

\footnotetext{
${ }^{260}$ Entrevista concedida em 08 nov. 2014.
}

${ }^{261}$ Entrevista concedida em 08 nov. 2014. 
sendo feito aqui. ${ }^{262}$

Pela qualidade e extensão do seu trabalho, a entidade tem sido reconhecida nacional e internacionalmente na promoção e preservação da memória política:

Um destaque especial deve ser concedido à perspectiva ampliada e
sistematizada do Trabalho do Núcleo de Memória Política do Fórum
dos ex-presos políticos de São Paulo que vem desenvolvendo
muitas iniciativas não oficiais de preservação da memória e de
busca da verdade (seminários, exposições, publicações
homenagens públicas, atividades culturais e reuniões de
mobilização em torno da justiça de transição).

É fato que entre as atividades realizadas pelo Núcleo Memória, os "Sábados Resistentes" são aquelas que mais se destacam enquanto "um marco para quem acompanha a trajetória da luta por Verdade, Memória e Justiça, no Estado de São Paulo, transformando o auditório do Memorial da Resistência em um espaço de reflexão e debate a respeito de diversos temas." ${ }^{264} \mathrm{O}$ diálogo entre as gerações e entre os acontecimentos do passado com presente, e o foco no papel da resistência política, são relevantes características do projeto:

Se aborda neles (Sábados Resistentes) a história política do passado, mas fundamentalmente vinculando-os a temas que tocam a atualidade. O espaço é hoje um lugar de encontro que ocorre aos sábados à tarde entre veteranos resistentes do passado e jovens resistentes de hoje. ${ }^{265}$

Em funcionamento desde 2008, os "Sábados Resistentes" já realizaram as mais diversas abordagens temáticas e o sucesso de público levou a um crescimento exponencial da atividade no calendário do Memorial. No ano de 2009, foram realizadas sete atividades, ao passo que em 2013 , foi realizado mais que o dobro de Sábados Resistentes, por exemplo. ${ }^{266}$

Inicialmente, como lembra Ivan, o grupo conseguiu negociar apenas um

\footnotetext{
${ }^{262}$ Entrevista concedida em 10 jan. 2015.

${ }^{263}$ ABRÃO \& TORELLY. 212.

${ }^{264}$ Artigo publicado por Núcleo Memória no sítio da Rede Latinoamericana de Sítios de Consciência. Disponível em <https://redlatinoamericanadesitiosdememoria.wordpress.com/reportajes-desde-lossitios/las-jornadas-de-sabados-resistentes-surgimiento-y-

potencialidades/?blogsub=confirming\#subscribe-blog.> Acesso em: 20 jun. 2015.

265 Idem.

${ }^{266}$ Disponível em:

<http://memorialdaresistenciasp.org.br/memorial/default.aspx?mn=41\&c=75\&s=0.> Acesso em: 18 abr. 2015.
} 
sábado por mês com os gestores públicos do Memorial. A crescente procura de público fez com que o próprio Memorial voltasse atrás e oferecesse mais tempo para estes encontros, como lembra o narrador:

E isso foi tão grande que esses Sábados Resistentes, que era só
uma vez por mês, como falei, de repente o próprio governo, a
Pinacoteca, falou: "Vocês não querem fazer dois por mês?" Eles é
que voltaram para gente. Por quê?? Porque a gente nunca fez aqui
um Sábado Resistente com menos de cem pessoas. O auditório
aqui são cento e oitenta lugares, se não me engano, e sempre
cheio. E elas colocam na lista de participação o seu e-mail e então
as pessoas recebem a programação, vem que é Sábado Resistente
e vem. ${ }^{267}$

São momentos em que lutadores experientes do passado e jovens resistentes de agora se encontram para troca de experiências e debates profundos sobre acontecimentos históricos, luta e envolvimento político. Por isso, Ivan vê muito mais que debates teóricos sendo extintos ali mesmo com o fim do encontro. Para ele, o interesse das pessoas em retornar é muito forte, o que acaba por fazer com que também se criem a partir dali verdadeiras relações de amizade.

\section{2 "E VOCÊS, RESISTEM A QUE?" 268 : NO ENCONTRO DE GERAÇÕES, O COMPROMISSO COM A JUVENTUDE}

Ecléa Bosi faz referência à forma como a nostalgia pode se reverter em expectativa por meio da memória revelada ao mundo por meio da oralidade, descortinando sua outra face: "a crítica da sociedade atual e o desejo de que o presente e o futuro nos devolvam alguma coisa preciosa que foi perdida."269

A autora ensina, ainda, que narrar é passar a experiência de "boca em boca", e que, diferente das histórias contadas pelos livros, "o narrador tira o que narra da própria experiência e a transforma em experiência dos que o escutam."270 É esta mesma troca que agora os ex-presos políticos podem realizar por meio dos do Memorial da Resistência, junto às gerações de jovens que não vivenciaram aqueles momentos de repressão e resistência na ditadura, mas que hoje vivenciam

\footnotetext{
${ }^{267}$ Entrevista concedida em 08 nov. 2014.

${ }^{268}$ Fala de Ivan Seixas na entrevista concedida em 08 nov. 2014.

${ }^{269} \mathrm{BOSI}, 2003$, p. 67.

${ }^{270} \mathrm{BOSI}, 1987$. p. 42.
} 
as experiências próprias de seu tempo.

Ao tratar do encontro de gerações por meio das narrativas de quem vivenciou experiências no passado e agora as compartilha com as novas gerações, Bosi (1987, p. 40-41) defende que:

Momentos desse mundo perdido podem ser compreendidos por
quem não os viveu e até humanizar o presente. A conversa
evocativa de um velho é sempre uma experiência profunda:
repassada de nostalgia, revolta, ressignificação pelo
desfiguramento das paisagens caras, pela desaparição de entes
amados, é semelhante a uma obra de arte.

A memória de pessoas mais velhas, ainda segundo a mesma autora, "pode ser trabalhada como um mediador entre a nossa geração e as testemunhas do passado. Ela é o intermediário informal da cultura, visto que existem mediadores formalizados constituídos pelas instituições (a escola, a igreja, os partidos políticos). ${ }^{271 " ~ B o s i ~ d e f e n d e, ~ a i n d a, ~ q u e ~ e ́ ~ p o r ~ m e i o ~ d a ~ m e m o ́ r i a ~ d a s ~ g e r a c ̧ o ̃ e s ~ d o ~}$ passado que podemos alcançar "um mundo social que possui uma riqueza e uma diversidade que não conhecemos."

Para o narrador Maurice, alcançar os jovens naturalmente distantes das experiências que são traduzidas no Memorial, requer justamente proporcionar-lhes um encontro pessoal com aqueles que vivenciaram as experiências, sendo esse um passo fundamental para que tenham a compreensão da narrativa histórica. Defende que, para "o jovem, quando dialoga com uma pessoa que esteve na situação, que esteve na cela, a percepção do momento é outra." Nesse encontro reside a "felicidade incomparável" defendida por Bosi, sentimento que surge quando se tem a oportunidade de estudar história recente amparado em "testemunhos vivos", podendo verdadeiramente "reconstituir comportamentos e sensibilidades de uma época!"273

A mesma ideia surge na fala de Ivan Seixas, para quem o propósito de toda a atuação junto ao Memorial da Resistência é, acima de tudo, a interação dialógica com a juventude:

A gente tem atuação voluntária, não somos remunerados para

\footnotetext{
${ }^{271}$ Idem, 2003, p. 15.

${ }^{272}$ BOSI, 1987. p. $40-41$.

${ }^{273} \mathrm{BOSI}, 2003$, p.16-17
} 
nada. É questão de militância, de consciência. Esses princípios nos guiam. Tanto para a construção de memoriais, quanto para conversar com os jovens. Nosso objetivo sempre é conversar com os jovens. A gente faz sempre uma ligação nas falas que a gente tem, nas palestras que a gente dáentre o que aconteceu no passado e o que acontece hoje, para ter uma reflexão sobre isso. ${ }^{274}$

A interação entre gerações tem um significado especial na experiência pessoal de Ivan, com outro ex-preso político que também participou da formação do Memorial. E da experiência entre eles, Ivan tira lições para si e que busca também compartilhar com os jovens, sobre luta, escolhas políticas e democracia:

O Martinelli, com os 90 anos dele ele tem um ensinamento para mim. Então ele tinha um ensinamento para mim, já naquela época, e tem um ensinamento para essa molecada hoje. É um cara que tem um papel na história que é marcante. Você não pode ignorar o Martinelli. É um cara que tem muita disposição de contar a experiência dele, inclusive, como exemplo de luta e exemplo de erros que possa ter cometido, para não se cometer mais. Esse é o nosso papel. De dizer: "Olha, faz. Mas não faça errado. Não repita erros. Erre erros novos e, principalmente, tenha a criatividade de explorar ao máximo todas as oportunidades da democracia. Quando não tiver democracia, é outra conversa. Aí a gente volta a conversar. Hoje não, não faça isso."275

Esse compromisso com a geração nascida já sob a égide da Constituição de 1988, fica latente na fala de Maurice, quando relembra o episódio em que um de seus torturadores tentou desqualificar a luta de resistência de sua geração afirmando que as próximas gerações seriam "deles". Passadas mais de quatro décadas, o narrador tem a resposta que não veio naquele dia no cárcere: "a gente está lutando para que essa geração não seja deles. E acho que está sendo um quinhão de areia." 276

Nesse contato intergeracional reside, ainda, a responsabilidade de romper com a falta de conhecimento, os estigmas e a apatia política. A mudança na percepção sobre um momento histórico não vivenciado surge como um sinal de que esta luta não pode ser abandonada. Rose Nogueira faz referências a reivindicações atuais de alguns grupos sociais no Brasil, que tem pedido pela destituição presidencial e pela volta da ditadura, para concluir que "muita gente não

\footnotetext{
274 Entrevista concedida em 08 nov. 2014.

${ }^{275}$ Entrevista concedida em 08 nov. 2014.

${ }^{276}$ Entrevista concedida em 10 jan. 2015.
} 
sabe o que aconteceu." 277

O encontro de ex-presos políticos com os jovens no Memorial da Resistência pode ser considerado um medidor qualificado sobre o grau de permeabilidade dos temas relativos à ditadura e à justiça de transição na juventude. Primeiro, aproveitando esses momentos como oportunidade de despertar nos jovens o interesse pelo debate político qualificado. Ivan Seixas lembra das primeiras reflexões sobre a forma de abordagem:

\begin{abstract}
Nas primeiras conversas que a gente teve, nos programas que 0 pessoal daqui desenvolveu e que são muito bonitos, de rodas de conversas com os professores e, também, palestras para os jovens, a gente teve um momento delicado que foram as primeiras palestras. "O que é que a gente vai dizer para os jovens?" Aí a gente teve que calibrar a oratória. Não podia ser um negócio punk, né. Só tortura e tal. Você tinha que falar alguma coisa que fizesse refletir. ${ }^{278}$
\end{abstract}

Havia, inicialmente, um interesse voltado mais especificamente ao modo de vida dos militantes: o método das torturas sofridas, o que causava mais dor, como era viver na clandestinidade, a vida na luta armada. Quem faz essa reflexão é o narrador Ivan. Para ele, essa constatação, naquele momento inicial dos trabalhos junto à juventude, foi um desalento.

O desconforto do narrador não se deu em razão de ter que falar sobre estas questões, mas pelo fato de não encontrar ali um espaço para debates mais profundos. Nesta época, por exemplo, Ivan lembra que os jovens creditavam à resistência política um atributo que pertenceria somente à juventude do passado. Foi então que decidiu "dar uma invertida" na lógica desses encontros com a juventude:

Então eu falei: "Deixa eu dar uma invertida aqui. Tudo bem, legal vocês falarem que a gente era resistente, que a gente resistiu à ditadura. $\mathrm{E}$ vocês, resistem a quê? Ou está tudo bom para vocês? A mídia, só fala a verdade, não engana vocês? A repressão sexual não existe? A repressão policial não existe? Tá tudo ótimo? Vocês não tem problema nenhum? Vocês não resistem a nada? Vocês são uma juventude satisfeita? Eu quero que vocês me respondam. ${ }^{279}$

\footnotetext{
${ }^{277}$ Entrevista concedida em 07 nov. 2014.

${ }^{278}$ Entrevista concedida em 08 nov. 2014.

${ }^{279}$ Entrevista concedida em 08 nov. 2014.
} 
Assim, foi criada uma dinâmica a partir da devolução da pergunta sobre resistência política aos jovens, abrindo margem à reflexão política e a um diálogo que partisse das experiências de resistência no passado até alcançar os problemas sociais e políticos atuais, gerando, atualmente, o que Ivan vê como uma "discussão muito legal." Para ele, quando as conversas partiram "da curiosidade para a reflexão", foi o início de uma "discussão absolutamente qualificada."

Há nesta forma de diálogo, um anunciado compromisso em manter acesa a ideia da resistência política como força motora de transformação da realidade social a qualquer tempo, como se vê na fala de Maurice:

A gente sempre devolve e pergunta: "E vocês, a que vocês
resistem?" Aí você pega os caras. "Como assim, o que o senhor
quer dizer com isso?" "A quê vocês resistem? Então, está tudo
muito bem, a escola está ótima, a Globo está ótima, o BBB que
você assiste todo dia? É isso que você quer?" Aí eles começam a
perceber. É isso que a gente quer, que eles resistam, nem que seja
no seu bairro.

No momento em que falam da possibilidade de diálogo com a juventude, talvez um dos maiores objetivos do grupo de ex-presos políticos na tarefa de promover a memória, surgem o sentido e a força da palavra "resistência". Ação que deu nome ao Memorial, no lugar da palavra "liberdade", a não-obediência a uma ordem de coisas, surge nas falas dos narradores como um elemento atemporal muito claro, permeando as "duas juventudes", do passado e do presente.

A resistência a que se referem os narradores, viajam no tempo e no espaço de suas recordações. Segue no enfrentamento à ditadura até chegar no enfrentamento à violência policial que assola as periferias nos dias atuais. Essa é, pois, para os narradores, uma questão que faz parte do presente, mesmo em um Estado Democrático de Direito, como afirma Pogrebinschi:

O amadurecimento do estado de direito não foi por si só capaz de garantir uma solução para o problema da legitimidade do poder. Os indivíduos da modernidade, transformados em cidadãos com direitos constitucionalmente assegurados, continuam a se insurgir contra o Estado, governado agora não apenas por homens, mas por leis. ${ }^{281}$

\footnotetext{
${ }^{280}$ Entrevista concedida em 10 jan. 2015.

${ }^{281}$ POGREBINSCHI, Thamy. O direito de resistência na teoria política contemporânea. LUGAR COMUM N 19-20. p.61-86. Disponível em <http://uninomade.net/wp-
} 
Chamada pelo pensamento contemporâneo de desobediência civil, a resistência política moderna, embora compartilhe da mesma essência rebelde com o novo conceito, também é dele diferenciada em alguns pontos. A não-violência, por exemplo, é atribuída conceitualmente à ideia de desobediência, ficando relacionada à resistência e revolução, o uso da violência ${ }^{282}$. Para os narradores da presente pesquisa, no entanto, parece não haver esta diferenciação. Denominam de resistência toda oposição popular em sentido amplo, que se insurja contra poderes do Estado, sempre marcada do sentido de:

[...] opor força ou resistência a; não ceder, não se dobrar; opor força à força; defender-se; fazer face a (um poder superior); opor-se; conservar-se firme e inabalável, não sucumbir; não aceder, negarse, recusar-se: sofrer, suportar; conservar-se, durar, subsistir; oferecer resistência. ${ }^{283}$

A resistência política presente em vários momentos da história do Brasil surge na narrativa de Rose Nogueira:

Você não pode abrir mão disso, você não pode abrir mão de quem você é, você não pode abrir mão de tudo que você traz. Nós trazemos quinhentos anos de dominação que a gente tem que brigar, mas nós trazemos também quinhentos anos de luta, !? A luta dos índios. Quer coisa mais bonita até hoje? ${ }^{284}$

Sua intenção, nesses momentos, é mostrar como a resistência faz parte do processo histórico brasileiro, não sendo algo relativo somente ao período de ditadura pós-1964. Mais adiante, a narradora identifica na história de vida das mulheres de sua família, imigrantes italianas, histórias de luta e resistência contra a opressão do sistema de trabalho nas fábricas têxteis. Essa batalha familiar confunde-se, nas lembranças de Rose, com toda uma luta do próprio operariado.

O uso ou não da violência nas ações de resistência política, surge na fala de Ivan. Nestes períodos, o narrador aproveita para dialogar com a juventude sobre as

content/files_mf/1130031208100\%20direito\%20de\%20resit\%C3\%AAncia\%20na\%20teoria\%20pol\%C $3 \%$ ADtica\%20contempor\%C3\%A2nea\%20-\%20Thamy\%20Pogrebinschi.pdf.> Acesso em: $13 / 04 / 2015$ ${ }^{282}$ POGREBINSCHI. P. 62-63.

${ }^{283}$ Michaelis. Dicionário de Português Online. Editora Melhoramentos. Disponível em: $<$ http://michaelis.uol.com.br/moderno/portugues/index.php?lingua=portuguesportugues\&palavra=resistir.>Acesso em 25/06/2015.

${ }^{284}$ Entrevista concedida em 07 nov. 2014. 
diferenças dos momentos históricos e, em consequência, das diversas formas de luta que se fazem necessárias e justificadas. É também nesse momento de sua fala que o narrador deixa transparecer a confiança na conquista democrática:

Não faça pregação da luta armada como sendo "o método". Hoje nós temos a democracia. Nós temos toda a convivência harmônica democrática, que é capenga, mas é. $E$ a gente tem a responsabilidade de pregar contra a luta armada agora. Nós temos que explorar as liberdades democráticas até onde for. Nós temos que usufruir. [...] O meu dever, inclusive historicamente, é desarmar essas bobagens que existem. E não é pouco, viu? [...] Você não pode romper, porque você vai ser criminoso. Porque é crime. (Eu digo) "Você sabe disso, que é crime? Você vai sequestrar, vai matar pessoas?" [...] Tem a justiça, você tem o Ministério Público, você tem a imprensa, você tem tudo funcionando. ${ }^{285}$

Nesses diálogos, o narrador vê a oportunidade de aprofundar a contextualização dos diferentes momentos históricos que justificam, por suas peculiaridades, as escolhas dos métodos de se opor ao Estado:

Nós fizemos, inclusive, para desarmar um monte de jovens que tem umas ideias, que me pegam para dar curso de guerrilha. Eu falo: "Não dou. Tá pensando que é curso de corte e costura." Não faço porque não é da sua cabeça que determina fazer luta armada. É um processo histórico. ${ }^{286}$

A experiência de vida de Ivan na resistência à ditadura parece ser o ponto de partida para os debates que trava com os jovens. Vê, nesses momentos a oportunidade de explicar o que diferencia, por exemplo, o desobediente (que para os narradores é o mesmo que resistente) do criminoso, lembrando os ensinamentos de seu pai ao justificar a escolha, naquele momento, pela luta armada:

"Vocês sabem qual foi a maior violência que cometeram contra
nós?" "Ah, o choque elétrico!" "Não. Foi nos transformar em
soldados. Meu pai era um mecânico. Virou um guerrilheiro. Eu, filho
de um mecânico, ia ser mecânico ou um operário de outra coisa
qualquer e me transformei num guerrilheiro. Foi uma violência muito
grande. Imagina o que é um cara que está acostumado com chave
inglesa, peças de motor, de repente está com um fuzil na mão, que
ensinou para o filho honestidade, não violência, respeito às leis,
que meu pai, apesar de comunista, sempre fez isso: "existe a lei,
você tem que respeitar." E de repente fala assim: "Nós vamos

\footnotetext{
${ }^{285}$ Entrevista concedida em 08 nov. 2014.

${ }^{286}$ Entrevista concedida em 08 nov. 2014.
} 
assaltar um banco, nós vamos sequestrar, vamos fazer sei mais o quê. Por causa da causa, porque a ditadura é que está errada. Então, nós temos que inverter." Então, foi uma grande violência. ${ }^{287}$

Trazer à discussão junto a um público jovem, o tema da resistência política, evidencia o grau de responsabilidade depositado pelo grupo de ex-presos políticos nesses encontros. São momentos em que o narrador Ivan aproveita para "desarmar" alguns mitos sobre luta armada e clandestinidade: "a gente tem esse papel também. O papel de lembrar, mas também de relativizar o que foi feito. Não é uma coisa grandiosa. Não é uma coisa boa para hoje. Pode ter sido no passado."288

Nesse instante de sua fala surge, também, um misto de confissão e desabafo sobre a própria percepção do que foi sua experiência na oposição à ditadura por meio da luta armada e também na clandestinidade:

Eu faço questão de dizer isso. Porque é o único jeito que você tem de desarmar essa tietagem, que eu acho que é a palavra certa. "É muita aventura?" Eu falo: "Isso não é aventura, cara. É um negócio sufocante." Você sabe o que é viver clandestino? "Fica todo mundo me olhando. Viver clandestino é você ter dois nomes. Se alguém chamar Ivan eu não posso virar a cabeça, porque eu posso denunciar que eu sou o Ivan. E se alguém chamar meu nome de guerra eu não posso virar a cabeça também, porque eu posso estar sendo vigiado e querem saber se eu sou aquele lá. $E$ quem tinha documento falso, tinha três nomes. O nome verdadeiro, o nome da carteira de identidade falsa e o nome de guerra. $E$ você não pode atender nenhum dos três. A sua cabeça tem que ser condicionada a descondicionar dessa coisa do reflexo, se não você pode se trair e você pode morrer. "Você acha que isso é uma vida boa, cara? "Pois é, isso é uma violência. Eu não acho que é uma coisa agradável e eu não vou pregar uma vida dessa forma. Eu acho que é um horror isso. Aí dá para dar uma amenizada.

Mexer com a estrutura de pensamentos dos jovens é um dos objetivos desse contato intergeracional apontados por Maurice. De acordo com o narrador, partindo de suas experiências de reação em face do estado de coisas que se apresentava durante a ditadura, é possível perceber nesses encontros com a juventude a oportunidade de trabalhar também os valores cultuados pela nova geração como, por exemplo, consumo e educação:

\footnotetext{
${ }^{287}$ Entrevista concedida em 08 nov. 2014.

${ }^{288}$ Entrevista concedida em 08 nov. 2014.
} 


\begin{abstract}
"Que valores você cultua? São os valores do shopping, do celular novo a cada três meses, de ir ao shopping. Esses são os valores que você têm? Tudo bem, mas esses são os valores que você quer? Ou você quer ajudar o próximo, que a sua sociedade seja melhor, que tenha mais educação? Então você tem que participar." E nessa participação tem a resistência. Aí você mexe um pouco com a estrutura de pensamento deles. É isso aí. ${ }^{289}$
\end{abstract}

O fomento dessas ideias despertadas nos jovens por meio do encontro com "os de antigamente", chamando-os para o despertar político, aponta para a riqueza da narrativa intergeracional, pois "para quem sabe ouvi-la é desalienadora, pois contrasta a riqueza e a potencialidade do homem-criador de cultura com a mínima figura do consumidor atual" (BOSI,1987, p. 41).

Há, nesses encontros, um chamamento à responsabilidade por questões políticas e sociais que permeiam a atualidade das vidas desses jovens, no sentido da cidadania defendida por Elizabeth Jelin, que engloba o compromisso cívico, "centrado em uma participação ativa na vida pública", e os aspectos simbólicos e éticos que conferem sentido de inserção e identidade, ou seja, sentido de comunidade. ${ }^{290}$

Quando os narradores falam do trabalho realizado junto aos jovens nos encontros do Memorial, insitando-os a pensar questões atuais, estão, na verdade, chamando-os a participarem dos dilemas e decisões relevantes para a vida da própria comunidade.

Além da promoção do diálogo, esses encontros também visam promover momentos de homenagem que celebram as lutas de personalidades e, também, de organizações, como o papel das lutas sindicais, das pessoas que foram para o exílio, de parlamentares e militares; outros momentos são mais didáticos, de modo a compartilhar informações históricas com os jovens, como a apresentação de chacinas emblemáticas, das grandes passeatas, a Guerrilha do Araguaia, a ditadura nos demais países na América Latina e sua interface com o Brasil. Esses

\footnotetext{
${ }^{289}$ Entrevista concedida em 10 jan. 2015.

${ }^{290}$ JELIN, Elizabeth. Cidadania Revisitada: Solidariedade, Responsabilidade e Direitos. In: JELIN, Elizabeth e HERSHBERG, Eric (orgs) Construindo a Democracia: Direitos Humanos, Cidadania e Sociedade na América Latina. São Paulo, EDUSP,2006, p. 155-179.
} 
são temas que foram abordados nos encontros de ex-presos políticos com jovens nos últimos anos, por meio do Memorial da Resistência.

No interesse de manter os acontecimentos do passado sempre em diálogo com situações do presente, os encontros tem tido como pautas temas bem contemporâneos como, por exemplo, as manifestações populares que tomaram as ruas do Brasil em junho de 2013, reivindicando, inicialmente, melhorias no transporte público em diversas cidades e que acabou por ter sua pauta ampliada para questões como o combate à corrupção; a democratização da comunicação; e os caminhos a serem tomados para o cumprimento das recomendações da Comissão Nacional da Verdade, publicadas em dezembro de 2014. ${ }^{291}$

A pauta se apresenta, assim, bem ampla e atual, como recorda Maurice:

E os temas que nós discutimos aqui vão desde o movimento das passeatas de junho de 2013, até a perseguição gay e LGBT na época da ditadura e a situação do negro. Fizemos muita homenagem a pessoas que foram mortas. (Falamos) sobre os torturadores. Fizemos incontáveis temas de discussões nos Sábados Resistentes. ${ }^{292}$

$\mathrm{O}$ crescimento de público jovem nesses encontros tem sido significativo. $\mathrm{O}$ local ordinário para esses encontros no Memorial comporta, segundo o narrador Maurice, mais ou menos 180 pessoas e era, nas suas lembranças, tomado, no início desses encontros, ainda em 2008, por "cotonetes, gente de cabelinho branco." Observa que com o passar do tempo essa realidade foi sendo modificada e os jovens passaram a compor a maioria dos frequentadores do evento. ${ }^{293}$

Por ser um evento permanente, realizado em um final de semana no período da tarde, o interesse crescente do público jovem desperta em Maurice sentimentos de muita surpresa e alegria:

[...] nós temos uma média de cento e vinte, sábado à tarde. Tem dia que tem trezentas, tem dia que tem cinquenta. [...] Mas se você pensar, sábado à tarde, sábado é dia que todo mundo quer fazer outras coisas, desde shopping até ficar em casa, e vir aqui para discutir? E hoje a maioria que vem aqui é gente jovem. E a gente

\footnotetext{
${ }^{291}$ Agenda dos Sábados Resistentes disponível em: <http://www.memorialdaresistenciasp.org.br/memorial/default.aspx? $\mathrm{mn}=41 \& \mathrm{c}=75 \& \mathrm{~s}=0 .>$ Acesso em: 28 jun. 2015.

${ }^{292}$ Entrevista concedida em 10 jan. 2015.

${ }^{293}$ Entrevista concedida em 10 jan. 2015.
} 
apresenta para eles, tema, por exemplo, como Guerrilha do Araguaia, e todos eles vêm porque querem saber o que foi, né? $\mathrm{E}$ a gente trás os personagens que viveram. Então eu acho que é um sucesso. A gente não esperava isso. ${ }^{294}$

Indo mais profundamente na pauta da transição democrática brasileira, o narrador Ivan atribui o crescente interesse da sociedade, em geral, pelos temas referentes à ditadura, também à mudança no cenário nacional, iniciada, como visto, no ano de 2007. Deixando os pequenos núcleos de militantes e pessoas mais diretamente interessadas no assunto, o narrador destaca eventos que passam a ser realizados no Brasil, por diversos órgãos, como sendo contribuintes no despertar social para o tema. Assim, o Memorial da Resistência e os encontros de gerações passariam a integrar uma gama de mecanismos promotores da transição.

Essa ampla visibilidade e ampliação do debate fizeram com que boa parte da sociedade refletisse e renovasse sua percepção sobre diversas questões políticas ligadas à ditadura no Brasil, a começar sobre o próprio entendimento do que foi aquele período - a falta de liberdade, a censura e a prática de crimes contra a humanidade por parte do Estado. As pessoas passaram a enxergar finalmente a existência não mais de um governo legítimo durante aquela época, mas sim a existência de uma "ditadura com torturas e assassinatos" e, também, a resistência. É com semblante de alívio que Ivan destaca aquele momento como um tempo de significativa mudança na percepção social sobre a própria identidade de quem resistiu à ditadura. Foi a oportunidade em que o narrador viu quebrarem-se estereótipos negativos da resistência política: "Antes disso, eu, Ivan Seixas, era terrorista. Depois disso eu passei a ser resistente." ${ }^{295}$ Aqui, o narrador identifica a ressignificação de sentidos que se faz possível a partir da troca de experiências, um acontecimento que aproxima as gerações, modificando e aprimorando percepções:

O ato de recordar e narrar gera, desta forma, uma oportunidade de converter o ouvinte em testemunha, [...] Os relatos emocionados evocam a dor e as marcas das atrocidades sofridas e, igualmente, as motivações ético-políticas que levaram os perseguidos a resistir contra um Estado autoritário. ${ }^{296}$

\footnotetext{
${ }^{294}$ Entrevista concedida em 10 jan. 2015.

${ }^{295}$ Entrevista concedida em 08 nov. 2014.

${ }^{296}$ ABRÃO, 2010, p.73.
} 
Experiências que unem aspectos como educação, reparação, memória, verdade e justiça em encontros intergeracionais se propõem a promover a quebra de versões parciais e distorcidas e obscurantismos relativos a um determinado acontecimento histórico, em especial, referente às violações de direitos humanos e a luta de resistência de uma época passada:

O testemunho compartilhado pelo perseguido político num espaço coletivo como das Caravanas propicia a reconstituição da história, o enfrentamento do passado e uma intensa valorização dos ideais e vivências. Aqueles que escutam são sensibilizados a compreendêlas sob o prisma dos atores sociais que, embora pretensamente invisibilizados pela "política da amnésia", foram protagonistas da história. Por meio do compartilhamento dessas experiências, um duplo movimento é desencadeado: por um lado, possibilita-se transformar a dor em conhecimento e, por outro, permite-se o fim adequado daquela, necessário à superação de uma tragédia: a elaboração do luto em vez do silenciamento. ${ }^{297}$

O encontro entre narrador e ouvinte, ainda que não em uma entrevista, mas sim em uma conversa, não é, como ensina Ecléa Bosi, um ato de "apropriação indébita", no qual um entrega ao outro sua experiência de vida. Em verdade, o que ocorre é que tanto um quanto outro tem a oportunidade de participar de uma "aventura comum" na qual degustarão, ao final, de uma sensação de gratidão: "o ouvinte pelo que aprendeu; o narrador, pelo justo orgulho de ter um passado tão digno de rememorar quanto o das pessoas ditas importantes."298

Esse encontro de gerações, em um espaço onde o jovem pode se encontrar com àqueles que vivenciaram as experiências de repressão e resistência e travar com eles um diálogo sobre as experiências vividas, tem despertado interesses que vão além dos espaços do Memorial.

Tem sido cada vez mais frequente o interesse de jovens estudantes de diversos níveis, em realizar pesquisas sobre a ditadura com a participação do grupo de ex-presos políticos. Não raro, ao final dos encontros, Ivan é abordado pelos jovens para contribuir com suas pesquisas e apresentar-lhes aos demais expresos. O narrador vê, nessa relação, algo que vai para além de uma colaboração com fins acadêmicos. $O$ interesse e a proximidade entre as duas gerações, criam

\footnotetext{
${ }^{297}$ Idem, 2010, p. 73.

${ }^{298}$ BOSI, 2003, p. 61.
} 
"uma relação" e uma espécie de "cumplicidade." Concluindo sua fala sobre esses encontros com a juventude, Ivan Seixas é taxativo: para ele, desses encontros, "saem coisas maravilhosas."

\section{3“AQUI NÃO É UMA QUESTÃO DE VIOLÊNCIA"299: ESPAÇO EXPOSITIVO MARCADO POR HOMENAGEM E SOLIDARIEDADE}

Ao trabalhar os sentidos do espaço na formação da memória coletiva Maurice Halbwachs (2003, p. 157), menciona que "as imagens habituais do mundo exterior são partes inseparáveis do nosso eu." Para o autor, nos apegamos aos objetos não por questão de estética ou comodidade e, sim, porque a atmosfera material que nos circunda traz gravada não só nossa marca mas também a dos outros.

Ecléa Bosi, ao tratar do significado dos objetos e dos espaços que nos cercam, ensina que os objetos, "mais que uma sensação estética ou de utilidade eles nos dão um assentimento à nossa posição no mundo, à nossa identidade; e os que estiveram sempre conosco falam à nossa alma em sua língua natal" (BOSI, 2003, p. 26).

Ao seguir os estudos sobre a relação do sujeito com os sentidos materiais de seu convívio, a autora defende que os objetos carregam as aventuras afetivas de quem deles fez uso. Dessa forma, é possível então, por meio deles e em contato com eles, aproximar-se da experiência vivida.

Tanto no clássico Halbwachs, quanto na leitura de Bosi, é possível identificar o quão significativos são os referenciais físicos que nos circundam, diferenciandose de nós, mas complementando a nós e a nossa própria história de vida.

Trazendo estas referências para um espaço onde se deram experiências coletivas, ainda que fora de um espaço doméstico, como é o caso do prédio do antigo DEOPS/SP, os referenciais materiais desse local guardam igualmente as marcas de um grupo. O espaço ocupado pelo grupo não é, como pontua Halbwachs, "um quadro-negro", uma lousa na qual se grava e apaga sentidos. Ao contrário, o que ali é "escrito" uma vez, por meio da experiência vivida, fica nele

\footnotetext{
${ }^{299}$ Fala de Ivan Seixas na entrevista concedida em 08 nov. 2014.
} 
marcado.

No Memorial da Resistência, além dos momentos de encontro com os perseguidos políticos que estiveram presos naquele espaço, é possível encontrarse também com o próprio prédio, que foi palco daquelas vivências e com a reconstituição física do que foram aquelas carceragens. Muitos encontros, inclusive, se realizam justamente nos espaços onde antes os ex-presos viveram as experiências ali reconstituídas e salvaguardadas, como nas Rodas de Conversas, encontros com alunos, e profissionais da educação e do turismo que se realizam no percurso expositivo.

Os espaços pensados para compor o Memorial da Resistência trazem em sua essência, desde a concepção do projeto museológico, a reconstituição das recordações dos ex-presos. Por meio de uma série de estímulos sensoriais, o espaço expositivo do Memorial se propõe a promover um diálogo entre repressão e resistência políticas, mediado por lembranças de quem viveu o passado que se quer reconstituir. Nas projeções expositivas, as lembranças dos ex-presos foram gravadas no concreto, no som, na imagem e nas luzes, de modo a reconstituir agora o que foi uma masmorra de suplícios e, também, um local de encontros e solidariedade. Há, assim, no projeto expositivo, uma mistura de informação e emoção, como identificou De Varine-Bohan:

Há neste Memorial uma alternância entre a informação- constituída por documentos de arquivos, fotos, o grande quadro cronológico, a história do prédio do DEOPS/SP - e a emoção, resultado dos cenários colocados nas celas, dos testemunhos registrados ou filmados. ${ }^{300}$

A proposta expositiva não se contentou em apenas levar o visitante a conhecer fisicamente as antigas celas do DEOPS/SP, em um mero admirar de objetos. Tão pouco se propôs a lançar mão de exposição de artes, objetos e documentos que não despertassem o visitante para a reflexão transformadora a que o espaço se pretende. Nesse sentido é que foram projetadas duas linhas expositivas, ambas pensadas como meios de diálogo com o público, principalmente, com os jovens - uma temporária e outra de longa duração.

\footnotetext{
${ }^{300}$ DE VARINE-BOHAN, 2009, p. 215.
} 
As "exposições temporárias" foram projetadas de modo a trazer ao local mostras periódicas, nacionais ou internacionais, que versem sobre temáticas conexas com o tema do Memorial. Já a "exposição de longa duração", apresenta uma mostra mais duradoura, não permanente, mas que se estende no tempo de modo a trazer ao visitante uma série de referenciais com os quais pretende por em diálogo e debate os seus diversos conteúdos. É nessa segunda forma de exposição que se dá, igualmente, a ocupação e a reconstituição da antiga carceragem do DEOPS/SP.

Logo em um de seus primeiros espaços de visitação, o Memorial provoca o visitante com os dizeres "lembrar é resistir", ${ }^{301}$ despertando o visitante para a razão de ser da própria necessidade de lembrar, traduzida nas paredes com ideias tais como "enquanto lembramos, tudo é possível." ${ }^{302}$ O primeiro espaço expositivo, logo na entrada do Memorial, é reservado à exposição temporária que vai, por meio de diversos temas relativos aos conteúdos do Memorial, preparar o visitante para uma imersão nas histórias de repressão e resistência políticas ocorridas no Brasil e na consequente reflexão sobre esses acontecimentos históricos.

A diversidade das temáticas abordadas nas exposições temporárias passa por escolhas que também consideram a opinião dos ex-presos políticos, por meio de votação que se dá no âmbito do Conselho de Orientação Cultural do Memorial da Resistência - $\mathrm{COC}^{303}$,- composto por representantes das sociedade civil, da academia, do Ministério Público, do Arquivo Nacional e da mesma forma, de representante dos ex-presos, atualmente na pessoa do narrador Maurice, membro do Núcleo Memória, do qual fazem parte vários outros ex-presos, dentre eles, mais dois narradores. ${ }^{304}$

A participação nas escolhas que decidem os caminhos a serem tomados na

\footnotetext{
${ }^{301}$ Título de uma peça teatral encenada nas suas carceragens antes mesmo da inauguração do Memorial da Resistência, no ano de 1999. O espetáculo, em cartaz de 9 de setembro de 1999 a 17 de dezembro de 2000 , teve o objetivo de "marcar a nova fase do uso do edifício, como um espaço ibre e democrático, sem permitir que fossem esquecidas as histórias de resistência e de opressão impregnadas nas paredes." Livro do Memorial, p. 31.

${ }^{302}$ Frase de Elie Wiesel grafada emuma das paredes do Memorial.

${ }^{303}$ Disponível em:

<http://memorialdaresistenciasp.org.br/memorial/default.aspx?mn=22\&c=82\&s=0.> Acesso em: 26 abr.2015.

${ }^{304}$ Como esclarecido anteriormente, também fazem parte do Núcleo Memória os narradores Elza Lobo e Ivan Seixas.
} 
vida do Memorial segue agora aquela intenção inicialmente construída, desde a concepção museológica, por meio de uma proposta de construção coletiva que unisse competências de profissionais com as vontades dos atores e testemunhas da época que se quer reconstituir.

Criou-se assim, no Memorial da Resistência, o que De Varine-Bohan vislumbrou como sendo "um sistema de cooperação que parece exemplar", ao unir, nas tomadas de decisão, para além da concepção museológica inicial, ex-presos políticos, agentes do Estado e profissionais especialistas das áreas de museologia e educação. ${ }^{305}$

A multiplicidade temática chama a atenção do narrador Ivan que vê nessa pluralidade uma forma de atrair o mesmo público diversas vezes:

E essas mostras que tem, as exposições como essa que tem agora, tem coisas maravilhosas sobre Marighella, sobre futebol, sobre a participação do negro, da mulher. Têm coisas espetaculares que foram feitas e sempre reavivam o interesse. ${ }^{306}$

Para a narradora Rose, há um forte caráter educativo nas mostras transitórias, à medida que exploram "outras batalhas históricas", além daquelas mais diretamente ligadas às experiências nacionais, momento em que a narradora também deixa emergir seu encantamento com temas com os quais se identifica na abordagem do Memorial:

Já teve exposições fantásticas lá, fantásticas. Às vezes sobre um assunto, um tema, às vezes sobre algumas pessoas, sobre um momento. Por exemplo, teve uma exposição lá maravilhosa. E todas são didáticas, com todas você aprende. Uma exposição das arpilheiras chilenas, as bordadeiras. Então, você viu como eu gosto de bordar, né? As bordadeiras chilenas que no bordado mandavam mensagens. $O$ bordado era o instrumento político e era também a representação daquela vida delas, tanto na resistência quanto na vida cotidiana das mulheres chilenas. Nossa, que coisa maravilhosa. E várias outras. Eu acho que é um lugar que atualmente já tem um acervo histórico do período da ditadura muito respeitado. ${ }^{307}$

Nos últimos anos, foram trazidos para esse espaço, os mais variados assuntos e com os mais diversos referenciais (fotografias, pinturas, objetos, etc.),

\footnotetext{
${ }^{305}$ DE VARINE-BOHAN.2009. p. 213.

${ }^{306}$ Entrevista concedida em 08 nov. 2014.

${ }^{307}$ Entrevista concedida em 07 nov. 2014.
} 
demonstrando riqueza de temas e abordagens: articulações entre as diversas ditaduras na América Latina; Operação Condor; advogados em defesa de presos políticos e na denúncia aos crimes que vinham sendo praticados; política e futebol; cumplicidade civil ao golpe de 1964 e durante toda a ditadura; e as dores da ausência causada pelas desaparições forçadas. São todos temas abordados nas exposições temporárias. ${ }^{308}$

Vista a mostra transitória, o Memorial convida ao percurso pela exposição de longa duração. A organização temática desse espaço dividiu o térreo do prédio do antigo DEOPS/SP em quatro módulos expositivos e é o espaço justamente concebido a partir da reconstituição das lembranças dos ex-presos políticos durante todo o processo de formação do projeto museológico do Memorial. Ali também colocaram, além de suas falas, também suas próprias mãos em reconstituição das marcas das vivências naquele cárcere, como se verá mais adiante.

De Varine-Bohan chama a atenção para a nomenclatura "longa duração" utilizada para descrever este espaço, em oposição ao termo mais comumente utilizado de "permanente". Para o estudioso, tal escolha denota a vocação dinâmica do Memorial da Resistência, apontando que não está fechado à possíveis mudanças futuras tratando-se de um lugar com "vontade de evolução e abertura." 309

De fato esta vocação tem sido levada à prática, como ressalta o narrador Maurice Politi. É ele quem conta as mudanças que estão previstas para serem implementadas no Memorial, com a preocupação de despertar novo interesse em quem já o conhece:

Agora vai mudar. Não sei se te falaram isso? Vai mudar a exposição de longa duração, porque os museólogos dizem que se uma pessoa veio uma vez, duas vezes, nunca mais. Aquele negócio de ouvir depoimento vai ficar. Vai ter outras histórias. Você consegue trazer aquele público para escutar outras histórias. Mas tem outras celas, por exemplo, aquela que tem os vídeos dos mortos, aquela vai mudar. Aquele lugar que é o Centro de Referência onde ficam os dois computadores, a gente viu que não é

\footnotetext{
${ }^{308}$ Mais detalhes disponíveis em

<http://www.memorialdaresistenciasp.org.br/memorial/default.aspx?c=exposicoes\&mod=anteriores\& $\mathrm{mn}=47$. . . Acesso em: 28 jun. 2015.

${ }^{309}$ DE VARINE-BOHAN, 2009, p. 221.
} 
eficiente. A pessoa acabou de visitar a cela não quer mais entrar ali, sabe? Eles estão tão impactados. A gente pensou no início: "Tem que ter um lugar, porque as pessoas vão querer saber mais. Então põe dois computadores com internet e ela entra nos lugares de memória no Chile." Mas o pessoal não faz. Então é um espaço perdido que vai ser remodelado. ${ }^{310}$

A fala de Maurice também deixa claro que essas modificações serão realizadas com a participação do grupo de ex-presos: "Vai ser uma remodelação que nós discutimos, nós também somos partícipes dessa remodelação. O Memorial vai ganhar mais espaço, o que é bom. Vamos ter mais espaço para exposição". ${ }^{311}$

Atualmente, os quatro módulos que compõem a exposição de longa duração são divididos do seguinte modo: três ambientes temáticos mais a carceragem, onde ficam as poucas celas remanescentes. Para a projeção deste espaço expositivo foram levados em conta alguns objetivos centrais convergentes para as escolhas das representações expográficas, a proporcionar ao visitante o encontro com os seguintes subtemas: o edifício e suas memórias; convergência e influências mútuas entre controle, repressão e resistência; cotidiano nas celas do DEOPS/SP; e centro de pesquisa. ${ }^{312}$

Ao iniciar a caminhada, o visitante é levado a conhecer a cronologia de ocupação do prédio, desde sua construção em 1851, passando pelas mais variadas reutilizações e momentos de abandono, até ser ocupado pelo DEOPS/SP, no período de 1940 a 1985, e chegar, em $1^{\circ}$ de maio de 2008, a seu novo destino: o Memorial da Resistência. À essa viagem na história de vida do próprio prédio, o Memorial atribui a importância de rememorar "vestígios que permitem confronto do presente com o passado", à medida que sua história "guarda os ruídos dos trens de ferro, as conversas dos trabalhadores que por aqui passavam rumo às estações do subúrbio, a fala estrangeira dos imigrantes em trânsito e os sussurros de cidadãos encarcerados"(ARAÚJO, 2009. p. 77).

Ao abordar a cronologia de ocupação do edifício, inaugurado em 1914, inicialmente, para o abrigo de escritórios e armazéns da Companhia de Estrada de Ferro Sorocabana, o Memorial se propõe a levar o visitante a conhecer momentos

\footnotetext{
${ }^{310}$ Entrevista concedida em 10 jan. 2015.

${ }^{311}$ Entrevista concedida em 10 jan. 2015.

${ }^{312}$ ARAÚJO, 2009, p. 74.
} 
de grande relevância da história da cidade de São Paulo, seus momentos de crescimento, a importância da ferrovia para a economia, bem como os tempos de sua decadência. Com a ocupação do lugar pelo DEOPS/SP, em 1940, e, em seguida, de outras repartições da Polícia Política, leva o público a refletir sobre "como, de um simples e periférico órgão público, ele passa gradativamente, mediante diversas articulações com instâncias de poder, a controlar e a reprimir, em diferentes dimensões, todas as esferas do país" (idem, p. 76).

Continuando a visita, o segundo módulo da exposição de longa duração leva ao tema "controle, repressão e resistência: o tempo político e a memória". Nesse espaço, o Memorial busca estimular a consciência social sobre as pressões e discordâncias políticas no percurso histórico brasileiro, muitas vezes invisível aos processos de aprendizado. Para tanto, faz uso de uma linha do tempo com destaque para acontecimentos geradores de conflitos políticos que ocorreram ao largo dos últimos dois séculos. Esse local interativo, com recursos multimídia, se propõe a permitir ao visitante aprofundar seu conhecimento sobre controle e repressão ampliando, dessa forma, seu conhecimento sobre o alcance e influência das ações engendradas pelo DEOPS/SP de modo diuturno na vida de milhares de cidadãos. $^{313}$

É também nesse momento, que o visitante é levado a conhecer a estrutura física das celas durante os anos de 1969 a 1971, por meio de uma maquete, que reconstitui a carceragem a partir das lembranças do grupo de ex-presos políticos.

O tempo das experiências de cada narrador naquelas celas é bem diverso, e a reconstituição do espaço reflete um emaranhado de lembranças da repressão que se une formando um grande tecido de memória social.

Rose Nogueira e Elza Lobo são as narradoras que estiveram naquelas carceragens ainda no ano de 1969 e ambas foram, posteriormente, transferidas para o Presídio Tiradentes. ${ }^{314}$ Em suas falas, nenhuma delas precisou o ano que

\footnotetext{
${ }^{313}$ ARAÚJO, 2009, p. 79.

${ }^{314}$ Sobre a passagem de Rose Nogueira pelo DEOPS/SP, busquei mais informação extraída da entrevista gravada pelo projeto do documentário "Torre das Donzelas", disponível em http://www.torredasdonzelas.com.br/vozes-da-memoria-videos/rose-nogueira-2/. Acesso em 30/06/2015. Sobre o periodo em que Elza Lobo esteve naquele órgão, busquei informações na entrevista também concedida para o mesmo projeto do documentário Torre das Donzelas, disponível em http://www.torredasdonzelas.com.br/vozes-da-memoria-videos/elza-lobo/. Acesso em
} 
chegou ao DEOPS. Elza, ainda, traz em sua narrativa a totalidade do tempo de prisão, não determinando, nos dois anos em que esteve presa, qual foi o período em que esteve em cada órgão da repressão.

As defasagens na ordem dos relatos e sequências de acontecimentos são segundo Bosi uma consequência da relação afetiva com a mobilidade espacial. Para a autora, quando há a passagem de um lugar ao outro, é possível que se criem borrões "de difícil restauração", nas lembranças. No entanto, a narrativa trará, por certo, uma intenção do sujeito: "ela (a narrativa) pode ser vista como um todo antes de ser segmentada pelo analista. Porque o sujeito aspira constantemente à totalidade, à plenitude de sua pessoa e sua história [...]" (BOSI, 2003, p.63).

Maurice chegou em seguida e é, dentre os narradores, ao contrário, o que evoca a lembrança mais precisa do tempo de DEOPS, contado em dias, meses e anos (entre 20 de abril e 18 de maio de 1970). ${ }^{315}$ Ivan chegaria mais tarde, permanecendo a primeira vez no período entre maio e setembro de 1971. Entre idas e vindas no período de 1971 a 1973, passou por lá o total de um ano e meio. $^{316}$

A diversidade do tempo de cada narrador naquelas carceragens enriquece a possibilidade de reconstituição das lembranças do espaço e apontou para as diversas alterações que aquela arquitetura sofreu ao longo dos anos, uma conclusão histórica que só se faz possível graças às recordações dos ex-presos políticos.

O trabalho de dar forma à reconstituição de uma estrutura que fez parte das experiências de vida do grupo, no caso as celas do DEOPS/SP, constitui-se em um esforço coletivo em que cada membro daquele grupo, ao compartilhar sua lembrança, oferece elementos que auxiliaram na composição das lembranças dos demais recordadores. Para Maurice Halbwachs esse fenômeno é explicado pela evocação das lembranças que um sujeito é capaz de provocar no outro, à medida que compartilharam experiências. Isso tanto se dará quanto maior for a ligação mental do grupo com as experiências compartilhadas, como parece ser o caso do

\footnotetext{
$01 / 07 / 2015$.

${ }^{315}$ Questionário eletrônico respondido em 02/06/2015.

${ }^{316}$ Questionário respondido em 02/06/2015.
} 
grupo de ex-presos políticos que participaram da formação do Memorial da Resistência. $^{317}$

Esse processo se dá, segundo o autor, enquanto germinação em que as lembranças de um sujeito são como espécie de semente da rememoração a esse conjunto de testemunhos exteriores ao outro sujeito, desencadeando um sistema coletivo que produza uma "consistente massa de lembranças." A partir desta "massa", se faz possível reconstituir referenciais desse passado, como é o caso da maquete que reconstitui as lembranças coletivas da carceragem do DEOPS/SP por meio das diversas recordações de quem lá esteve por distintos momentos. ${ }^{318}$

Outra observação relevante é notar que a reconstituição coletiva das celas foi realizada a partir de recordações de pessoas que viveram experiências no mesmo espaço, mas em tempos diferentes. Ainda assim, elas se enxergam como um grupo que compartilhou experiências. É exatamente a ideia já apresentada por Halbwachs, sobre a composição da memória coletiva a partir da ligação mental de diversos sujeitos de um mesmo grupo, a partir das experiências compartilhadas, no caso, a situação de resistência à ditadura que os levou à condição de perseguidos políticos. $^{319}$

Após conhecer a história do edifício, as memórias da repressão política e seu papel histórico também em relação aos conflitos sociais de outros tempos, o visitante, a partir desse instante, é convidado a cruzar o corredor que leva às quatro celas remanescentes e ao corredor de banho de sol, o espaço que efetivamente abrigou as experiências dos ex-presos políticos naquele prédio. A partir dali, o espaço expositivo ganha as marcas das recordações de sofrimento, humilhação e arbítrio do Estado de exceção, mas também, e surpreendentemente, de descansos, encontros, solidariedade e afeto praticados entre os presos políticos.

A intenção em levar o visitante para dentro do espaço onde as experiências foram vivenciadas, para além de despertar a curiosidade de conhecer um lugar com tamanha carga histórica, reside em redefinir as próprias histórias de violações que se fizeram presentes ali. Configura, assim, imprimir novo significado ao "som

\footnotetext{
317 HALBWACHS, 2006. p. 33.

${ }^{318}$ Idem, 2006. p. 33

${ }^{319}$ Idem, 2006. p. 98.
} 
dramático do abrir e do fechar das celas, da luz que nunca se apagava, do barulho do trem que passava ao lado, da resistência que se apoiava nos ecos vindos das manifestações de apoio externas a essas paredes."322

Para aquele que não vivenciou uma época ou experiência, pisar o mesmo chão que foi palco vivo daquelas histórias, potencializa um encontro mais visceral com o passado de modo a despertar no sujeito o sentimento de alteridade e compaixão com as histórias ali contadas. Do mesmo modo que o diálogo com a testemunha do passado provoca esta proximidade, também o encontro com o espaço que foi cenário das experiências, cumpre o mesmo papel. Ao entrar em contato com o concreto, as cores, vozes, luzes e sons, o visitante se vê dentro do cenário que fez parte daquela experiência, momento em que é provocado a passar de visitante a ator da própria história.

Na primeira cela, o Memorial da Resistência narra o processo de sua própria formação, criando no espaço um acervo da história de seu nascimento. Ali apresenta fotos, textos e narrativas dos ex-presos políticos que atuaram desde o processo de concepção museológica, a montagem da exposição de longa duração, o processo de reconstituição e sua inauguração. Neste momento, justifica ao visitante sua escolha museológica por lembrar o cotidiano dos ex-presos políticos nas celas, a burocracia que dava suporte aos horrores praticados pela repressão e a política de controle e, também, a consolidação de uma prática interna dos presos em resistir e confiar na mudança e na forma como as manifestações externas ecoavam para eles. Ao justificar suas escolhas ao visitante, o Memorial proporciona uma reflexão sobre "os dilemas dos processos preservacionistas", que impõe a escolha daquilo que será representado ou não e daquilo que será ou não lembrado.

Convertendo-se em espaço de homenagem aos resistentes, a segunda cela faz referência aos que morreram e aos que continuam desaparecidos, alertando ao visitante sobre a responsabilidade do Estado em relação aos crimes cometidos. Através de projeções de fotografias, textos e sons, entre centenas de histórias que acabaram desta forma no Brasil durante aqueles anos, a composição expográfica optou por fazer um tributo a quatro ex-presos políticos que morreram em circunstâncias ligadas diretamente à sua passagem por aquelas carceragens e

\footnotetext{
${ }^{322}$ ARAÚJO, 2009, p. 81.
} 
pelas mãos dos agentes que lá atuavam. São personagens e histórias lembradas em detalhes pelo narrador Ivan:

As pessoas morreram aqui. Morreram torturadas. Aquelas quatro pessoas que aparecem, você deve ter visto lá, são quatro que morreram aqui. Aí você tem lá o que era meu comandante, Devanir José de Carvalho, torneiro mecânico; o Bacuri, que era um operário de telefonia; o Olavo Hansen, um trotskista que era estudante de química e ao mesmo tempo operário; e o Luiz Hirata, que era um estudante da AP (Ação Popular Marxista Leninista do Brasil) e também um operário, que era da oposição sindical. ${ }^{323}$

Essas mortes no prédio e agora reconstituídas no Memorial da Resistência, revestem-se de homenagem e de luto, esse último, traduzido dentro do contexto das desaparições forçadas pela jurista Inês Virgínia Prado Soares, como sendo o "rito social de lembranças, realçando a ausência de algo ou alguém que se perdeu, fornecendo publicidade à saudade do desaparecido." ${ }^{324}$ Nesse enredo, Soares defende que a guarda do luto dos desaparecidos políticos e, por analogia, também os declaradamente mortos, permite o desfrute da memória coletiva em um panorama democrático, atuando igualmente como reparação simbólica.

Criar um espaço em consideração às vítimas de crimes de Estado, é uma forma de denúncia dessas atrocidades, atuando como fonte histórica da repressão política, e acesso público à informação e de exercício do direito à verdade. Lembrar do assassinato do estudante de engenharia Olavo Hansen, por exemplo, é mostrar a forma violenta, mentirosa e ardilosa com que agiam os diversos órgãos de segurança. Inicialmente apresentado a público como mais um caso de suicídio, justificativa forjada muito usada pela polícia política, assim como a morte em confronto policial, Olavo foi vítima de intensas torturas nas dependências do DEOPS. ${ }^{325}$

\footnotetext{
${ }^{323}$ Entrevista concedida em 08 nov. 2014.

${ }^{324}$ SOARES, Inês Virgínia Prado. Memória democrática e desaparecidos politicos. Memória e Verdade: a Justiça de Transição no Estado Democrático Brasileiro. Coordenadoras Inês Virgínia Prado Soares e Sandra Akemi Shimada Kishi. Belo Horizonte: Fórum, 2009, 322 p. 317355.

${ }^{325}$ Relatório CNV: "Passou por diversos presídios - Batalhão Tobias Aguiar, QG da Polícia Militar, OBAN e finalmente DOPS, onde ficou detido na cela $\mathrm{n}^{\circ} 2$. No dia 5 de maio, foi retirado dessa cela e conduzido à sala de interrogatórios, onde permaneceu por mais de 6 horas. Na volta, os companheiros ouviram dele o relato das torturas sofridas: obrigado a despir-se, sofreu queimaduras com cigarros e charutos, choques elétricos oriundos do tubo de imagens de um televisor, palmatória nos pés e nas mãos, espancamentos e pau-de-arara com afogamentos. [...] O estado de Olavo
} 
Mais que a lembrança em forma de homenagem, Ivan Seixas compreende que lembrar os mortos e desaparecidos naquele espaço é também parte do processo de ressignificar as violações ali cometidas. Mesmo a morte não descaracteriza o embate, a oposição e a resistência a um sistema de forças políticas. O enfoque daquele espaço é, para ele, mesmo abordando a temática tão dolorosa das perdas fatais, não a tragédia, mas "a grandeza humana." Esta é, para ele, a grande marca do Memorial:

Para nós, naquele momento, foi extremamente importante a gente
dar essa marca. Aqui não é uma questão da violência. A violência
está presente em tudo. Eles criaram aquela segunda sala, a
primeira mostra o que foi a construção, onde estamos discutindo, a
segunda é uma homenagem aos mortos e desaparecidos. [...] A
gente homenageou, porque eles morreram aqui dentro. Para nós
era muito importante fazer uma homenagem dizendo "torturados,
são homenageados". Então a tortura está presente. E aí para ter
essa marca, de não ser uma coisa voltada para a tragédia e, sim,
para a grandeza humana da solidariedade, é que a gente construiu
isso. ${ }^{226}$

Para o narrador, ao homenagear os resistentes, até mesmo aqueles que sucumbiram nas mãos dos agentes de Estado, em um espaço que continua a resistência política agora por meio do diálogo com a nova geração, o Memorial mostra que "a humanidade venceu a barbárie":

Com uma marca que para nós era muito importante: a humanidade venceu a barbárie. Se nós temos isso hoje, essa é a prova maior, que toda barbárie, torturas, assassinatos, eram dominantes naquele momento, mas hoje quem manda somos nós. É a humanidade que venceu. ${ }^{327}$

A partir das memórias individuais do grupo de ex-presos políticos sobre os dias e meses vivenciados na rotina das carceragens do DEOPS/SP, a terceira cela se apresenta ao visitante como uma reconstituição do dia a dia nas celas. Ali são reconstituídos iluminação, disposição de mobiliário, cores e texturas que refletem as múltiplas e complementares lembranças de quem passou por ali em algum

\footnotetext{
vinha se agravando a cada dia. Os demais presos políticos promoveram manifestações coletivas para que fosse providenciada assistência médica efetiva. Tudo em vão. [...] No dia 13 de maio, a família foi informada de que Olavo se suicidara no dia 9, intoxicado por ter ingerido o inseticida Paration."

${ }^{326}$ Entrevista concedida em 08 nov. 2014.

${ }^{327}$ Entrevista concedida em 08 nov. 2014.
} 
momento. Há a reconstituição do varal improvisado com toalhas penduradas, o banheiro de piso quadriculado em preto e branco, a luz "bem fraca" do banheiro, uma "piazinha" para escovar os dentes e lavar o rosto, o banho de "canequinha", referência aos 16 colchonetes para 16 ou 18 presos. Tudo, reconstituído a partir da diversidade das recordações do grupo dos oito ex-presos políticos, formando, mais uma vez, um emaranhado de fios do tecido da memória social. ${ }^{328}$

Foi nesse ambiente que tomou corpo um símbolo que surge de modo muito marcante nas falas dos quatro narradores: as inscrições nas paredes das celas dos nomes de diversos presos políticos que por ali passaram. Esse foi um hábito desenvolvido pelos presos políticos de sempre gravar seus nomes nas paredes das celas do Departamento como forma de marcar sua passagem por aquele órgão. $A$ ideia buscava burlar a clandestinidade das prisões, os sequestros e mortes que aconteciam corriqueiramente e de modo velado dentro dos órgãos de repressão, e também servir à comunicação entre os próprios presos. Dessa forma, quando se chegava a uma cela do DEOPS já era possível saber quem passou lá. Foi assim que Ivan soube, por exemplo, que estava na mesma cela por onde haviam passado, em outras épocas, Monteiro Lobato e Caio Prado. Outra lembrança faz referência a palavras escritas com sangue, dizendo para a namorada "eu resisti até onde deu." 329

Na reconstituição desse símbolo na exposição do Memorial, o grupo de expresos foi fundamental. Foram eles que, reunidos em torno da evocação de suas lembranças pegaram em ferramentas para gravar a recomposição do que viram naquelas celas. Foi quando Ivan fez questão de recompor as gravações de Monteiro Lobato e Caio Prado.

Chegando à quarta e última cela, o visitante se depara com um cravo vermelho dentro de uma garrafa, bem ao centro, sobre um caixote de madeira e sob um única luz incidente. É Ivan que recorda o fato que gerou a representação da flor no Memorial:

Até que chega a história do cravo. A Elza Lobo conta que um dia ela pensou "Eu tenho visita e ninguém mais tem. Não dá para trazer

\footnotetext{
${ }^{328}$ Memorial da Resistência - Ensaio fotográfico de Pablo Di Giulio. Livro do Memorial, p. $99-137$.

${ }^{329}$ Registro de um ex-preso político no vídeo "Memória do DEOPS", publicado em 03/03/2010. Disponível em: <https://www.youtube.com/watch?v=BYvtJNOnwR8.> Acesso em: 18 jul. 2014.
} 
comida para todo mundo, vou trazer uma coisa que seja bonita para todo mundo", e pediu para mãe trazer flores. A mãe trouxe cravos e ela mandou entregar um cravo para cada preso. ${ }^{330}$

A história que traduz o simbolismo daquela flor é uma dentre tantas outras narrativas de ex-presos disponíveis em inúmeros fones de ouvido espalhados ao longo da cela. Pensado como "evocação sobre os valores que foram preservados, apesar de todas as provações de que essas personagens foram alvo", o espaço evoca os testemunhos das experiências de solidariedade e esperança vivenciadas naqueles tempos, como resgata Ivan:

Os depoimentos, o que é que têm ali? Tem que quando alguém chegava torturado, isso remete à tortura e a gente não esconde a tortura, mas quando alguém chegava torturado a gente estava junto, a gente puxava para o colchão, a gente dava comida, levava no banheiro e tal, porque estava quebrado, porque fizeram isso conosco. A marca que tem nos depoimentos é essa de solidariedade, de carinho de um ser humano com o outro. Então em vários depoimentos ali o que você vê é a preocupação não consigo mesmo mas com o próximo. ${ }^{331}$

A flor, trocada periodicamente, como se devem trocar as flores que enfeitam e perfumam os ambientes cheios de vida, surpreende e emociona os visitantes: "pensei que o cravo estaria vivo apenas na inauguração. Para minha surpresa, o cravo vermelho se mantém vivo no centro da cela e daqui por diante no meu coração. Viva a luta pela democracia e socialismo." ${ }^{332}$

Ao deixar a última cela, o visitante encontra referência ao culto religioso realizado por frades dominicanos presos no DEOPS, mais uma forma de resistência política. A missa realizada "nos subterrâneos do DEOPS" é narrada por Frei Betto, também preso naquelas carceragens, e um dos oito presos que colaborou no processo de formação do Memorial. Para ele, a ideia animou a todos os presos políticos, "inclusive os marxistas ateus." ${ }^{333} \mathrm{Em}$ seu livro narra a realização da missa, como um momento que "quebraria o espesso clima de atrocidades e permitiria, mais uma vez, a tentativa de recuperação de nosso espaço vital", e que inspiraria o desenho que permanece atualmente pintado na

\footnotetext{
${ }^{330}$ Entrevista concedida em 08 nov. 2014.

${ }^{331}$ Entrevista concedida em 08 nov. 2014.

${ }^{332}$ Conferir sessão "A voz dos visitantes" no livro Memorial da Resistência, 2009, p.173.

${ }^{333}$ BETTO, 1983, p. 344-345.
} 
parede do Memorial:

o carcereiro Adão permitiu que o monsenhor Marcelo celebrasse no corredor, onde foi colocada a pequena mesa que serviu de altar. $\mathrm{O}$ cálice, uma caneca de alumínio. As hóstias ficaram depositadas num desses pratos de papelão utilizados em pizzas para viagem. Tudo simples e rústico, como as antigas celebrações nas catacumbas romanas. Os padres e religiosos puderam ficar fora das celas, junto ao altar. Jeová também saiu, carregado numa cadeira. Os companheiros permaneceram espremidos nas grades. Nas pontas do corredor, a tropa de choque da PM apontava-nos metralhadoras. Os carcereiros olhavam espantados. Observavam, curiosos e silentes, as nossas orações e cânticos. [...] Era a primeira vez que participávamos de uma celebração na qual predominavam comunistas. [...] A litania não tinha fim. Todos tinham muito a dizer e a pedir. Parentes e companheiros eram lembrados. As súplicas transformaram-se num momento de livre manifestação, no qual os prisioneiros mostraram-se indiferentes à presença dos guardas e dos carcereiros. A cada intenção, todos acrescentavam: - Senhor, ouvi a nossas preces. ${ }^{334}$

Correndo as celas pelo lado de fora, o corredor do "banho de sol" é também espaço de visitação, local onde, segundo Maurice Politi, os presos reclamavam "pedindo para sair ao sol, principalmente, para se movimentar e para poder ver os companheiros através das grades e fechar história com os demais."

$\mathrm{Na}$ sequência, o corredor interno ao longo das celas, com o chamamento "Do lado de fora deste edifício: outras memórias" faz referência às manifestações que se davam nas ruas, em repúdio às prisões arbitrárias, aos sequestros, às torturas e assassinatos, e que, ultrapassando as paredes e grades, reverberavam nas carceragens, dando ânimo aos presos. Era a resistência das ruas refletindo dentro das celas.

O que se vê ao final do percurso das celas e, da própria exposição de longa duração, é de fato uma ode não às violações, sofrimentos e dores, mas sim à resistência política, em todas suas representações, no sentido de manter-se firme, em oposição a um regime autoritário, de arbítrios e violações de direitos. $\mathrm{Na}$ resistência, morrer ou sobreviver são igualmente formas de resistir. Assim como estar preso, clandestino ou exiliado. Os narradores não fazem essa diferenciação.

\footnotetext{
${ }_{335}^{334}$ dem, p.. 345-349.

${ }_{335}$ Registro no vídeo "Memória do DEOPS", publicado em 03/03/2010 em <https://www.youtube.com/watch?v=BYvtJNOnwR8.> Acesso em: 18 jul. 2014.
} 
Querem deixar no espaço a marca de todas essas formas de resistência. A resistência de quem morreu por lutar. A resistência no cuidado com as chagas do companheiro de cela. A resistência na organização e na distribuição das tarefas na rotina das carceragens. A resistência gravada nas paredes. A resistência nas celebrações daqueles encontros. A resistência de voltar, mais de quatro décadas depois, para lançar luz sobre essas experiências em reflexão com a anova geração.

\section{4 "UM GRÃOZINHO DE AREIA" 336 : A PERCEPÇÃO DOS EX-PRESOS POLÍTICOS SOBRE OS RESULTADOS DO MEMORIAL DA RESISTÊNCIA}

A conquista do prédio do DEOPS e sua transformação em espaço de cidadania é, sem dúvida, muito comemorada em todas as falas. No entanto, há também um sentimento claro para todos os entrevistados, de que esse é somente um dos passos, dentre tantos outros necessários à construção e promoção da memória.

A dimensão alcançada pelo Memorial da Resistência, tanto em relação ao nível de profissionalismo do projeto, quanto à repercussão dele junto à sociedade, são, para Maurice Politi, uma grande surpresa: "nunca imaginava que ia ser esse sucesso."337

O livro assinado pelos visitantes na saída do Memorial dá alguns indicativos de como essa experiência de entrar em contato direto com o cenário das histórias que se quer narrar, em especial, quando se trata de contar sobre experiências de graves violações de direitos humanos, alcança o ouvinte.

O significado deste contato, para quem não viveu diretamente as experiências, pode despertar a certeza da importância da preservação dos espaços na sua integralidade para a preservação da própria memória. Na mensagem "É lamentável que se destrua patrimônio, história, monumentos como, por exemplo,

\footnotetext{
${ }^{336}$ Fala de Maurice Politi em entrevista concedida em 10 jan. 2015.

${ }^{337}$ Entrevista concedida em 10 jan. 2015.
} 
Carandiru, Preservar a História!" ${ }^{338}$, visitante estende a perspectiva da preservação da memória das violações do DEOPS para outro caso igualmente de violência cometida pelo próprio Estado, em época mais recente, em referência ao Presídio do Carandiru, também na cidade de São Paulo, palco da morte de 111 presos comuns no ano de 1990 cujo prédio foi demolido e o local transformado no Parque da Juventude.

O Memorial da Resistência firma-se atualmente como um dos museus mais visitados da cidade de São Paulo, com média mensal de 70 mil pessoas por ano e 200 por dia no período de férias, com público de diversos estados e países, segundo Maurice.

Dessa forma, o Memorial foi considerado por De Varine-Bohan como um "modelo a seguir" e, "em razão de seu objeto e da amplitude", um projeto sem equivalente no Brasil. ${ }^{339}$

Todo esse alcance de público faz dele o que Maurice define, brincando, como sendo "o melhor e o pior lugar do Brasil. É o melhor, porque é o único, mas também é o pior, porque é o único."340

Os resultados alcançados são medidos de várias formas pelo grupo de narradores, inclusive pela quantidade de público interessado e pela crescente procura pelas atividades mediadas. É com ares de orgulho que Ivan apresenta o número de visitantes que o Memorial recebe:

[...] sete a oito mil pessoas por mês que vem aqui, pelos que são contados, fora os que entram e saem e você não sabe. [...] E você acha que têm visitantes basicamente de São Paulo? Não, você tem visitantes de outros países, outros estados, outras cidades. Então, é de uma importância muito grande. ${ }^{341}$

Nas suas contas, o Memorial é o terceiro ou quarto museu mais visitado no Estado de São Paulo e está bem administrado, "dando um resultado espetacular." O narrador expressa seu contentamento com os resultados pela atração que promove junto ao público jovem e à área da educação: "eu acho que é isso que a gente queria, não é? Então, eu só consigo imaginar que a gente fez o que tinha

\footnotetext{
${ }^{338}$ Ver "Voz dos visitantes" no livro Memorial da Resistência de São Paulo. p. 173.

${ }^{339}$ VARINE-BOHAN, Hugues de. 2009. 217.

${ }^{340}$ Entrevista concedida em 10 jan. 2015.

${ }^{341}$ Entrevista concedida em 08 nov. 2014.
} 
que fazer. E o produto final, o resultado eu acho que foi espetacular." ${ }^{342}$

Maurice Politi confirma este ranking, lembrando um cenário positivo de crescente interesse de público em relação ao Memorial, fato que o surpreende, principalmente, por se tratar de "um tema que não está nos livros." Segundo suas contas, o Memorial da Resistência já esteve em sexto lugar dentre os museus mais visitados da cidade de São Paulo, estando agora em quinto ${ }^{343}$. Neste cálculo, não deixa de demonstrar o tamanho de sua surpresa, também, em consideração a algumas questões que considera obstáculos ao interesse social, como a localização não tão acessível em termos territoriais e que, ainda assim, não impede seu grande número de visitantes mensais.

O livro de registros do Memorial é também o grande medidor do alcance do projeto para Ivan, material que já teve, inclusive, um de seus volumes furtados, como lembra com diversão. Ele conta que faz questão de ler o livro com certa frequência porque sempre sai "com a emoção redobrada." Entre as manifestações escritas dos visitantes, Ivan destaca algumas falas que muito o emocionam. São registros de ex-presos que nunca mais tinham pisado no lugar; filhos e netos de expresos; pessoas que nunca tinham ouvido falar daquelas histórias e que se deixaram tocar por elas:

Deixam nome, sobrenome, local e comentário. Você imagina o que é você ler "Obrigado, resistentes. Temos democracia graças a vocês." Isso derruba qualquer um. E também assim, um agradecimento ao Memorial: "Obrigado. Agora eu conheço o local onde meu pai esteve preso." "Eu nunca soube disso.", ou "Agora eu conheço o local onde minha avó esteve presa." Entendeu? É um negócio emocionante. Fora comentários do tipo: "Lindo, maravilhoso. Super importante." Então você olha ali, assim, é um negócio fascinante. É fascinante. ${ }^{344}$

O interesse despertado, especialmente, no público jovem é um dos grandes medidores de sucesso no trabalho realizado no Memorial e ganha destaque na fala de Ivan: "Vamos dizer que esse era o objetivo inicial. A gente alcançar a juventude para ela se interessar por esse assunto. E a gente já tem isso."

\footnotetext{
${ }^{342}$ Entrevista concedida em 10 jan. 2015.

${ }^{343}$ Teria a sua frente somente o Museu do Futebol, o MASP, a Pinacoteca e o Museu de Artes Sacras, passando o MIS e o Tomie Ohtake.

${ }^{344}$ Entrevista concedida em 08 nov. 2014.
} 
Ao servir de palco para o diálogo entre as gerações, o Memorial tem se colocado a serviço da construção de novos valores, como instrumento da cultural nacional, como acredita a narradora Rose:

O Memorial ele faz parte disso para que a gente possa continuar nessa coisa. Existe uma cultura brasileira e ele faz parte disso. Para que ela possa se perpetuar. Para as próximas gerações e para que nunca mais a gente tenha uma ditadura perversa daquela, embora tenha gente que fica abrindo faixa, pedindo intervenção militar sem saber nem do que se trata, porque está sendo levado pelas forças que nós combatíamos e que tomaram conta do Brasil junto com os militares, o chamado imperialismo. ${ }^{345}$

A possibilidade de colaborar com a transformação social por meio do Memorial é, ainda, segundo o narrador Maurice, um sinal de que ele e o grupo de ex-presos políticos estão cumprindo com seu papel, mesmo que com "um grãozinho de areia": "a gente queria transformar a sociedade e nós estamos transformando pouco a pouco, pelo menos para a próxima geração."346

\footnotetext{
${ }^{345}$ Entrevista concedida em 07 nov. 2014.

${ }^{346}$ Entrevista concedida em 10 jan. 2015.
} 
"NEM HERÓIS, NEM VÍTIMAS"

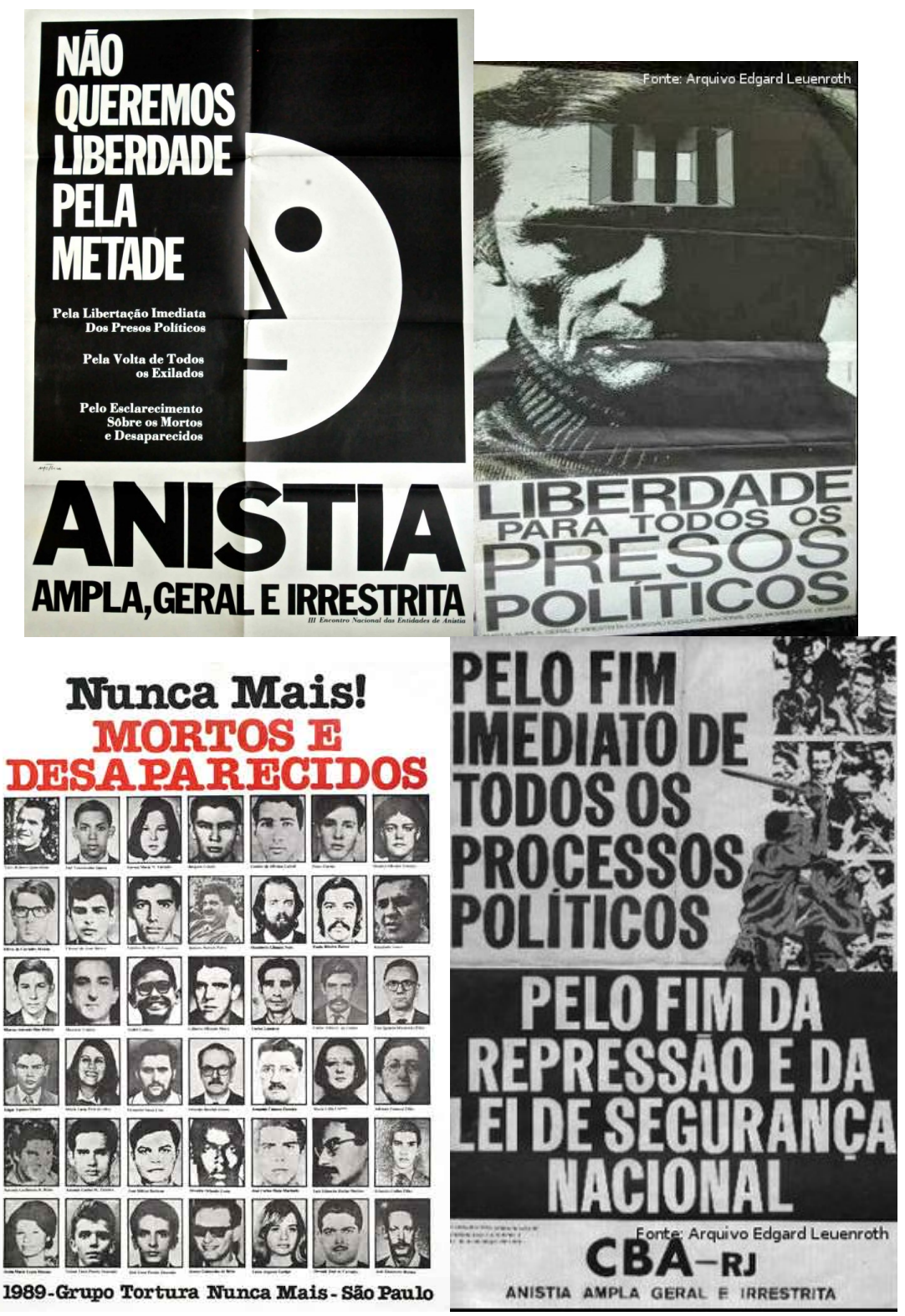

Ilustrações 3: Cartazes de campanhas pelo fim da ditadura. 


\section{3 "NEM HERÓIS, NEM VÍTIMAS" "347: A ESCOLHA PELOS CAMINHOS DE LUTA NA DITADURA E NA DEMOCRACIA}

Este terceiro e último capítulo é dedicado à análise das lembranças dos quatro narradores a partir das reconstituições das experiências vividas durante a ditadura até o reencontro do grupo em torno da formação do Memorial da Resistência, a partir de três enfoques: a escolha pela resistência política em diante do regime de exceção, ainda durante a juventude; a experiência nas mãos da repressão; e a escolha pela continuidade da luta em defesa e promoção dos direitos humanos após a abertura política. Embora sejam lembranças de um período que não se encerra no núcleo central da presente pesquisa, são recomposições que apontam os perfis dos narradores, auxiliando na compreensão de suas escolhas políticas. É o passado contribuindo para a compreensão do presente. São as reconstituições das recordações da militância estudantil, da atuação em organizações de resistência, clandestinidade e luta armada. Da experiência nas mãos dos agentes da repressão, emergem lembranças de perdas, dores, medos e incertezas, e também da solidariedade surgida no convívio com os companheiros de cárcere. Por fim, um destaque às falas sobre a persistência na defesa dos direitos humanos e em prol da dignidade humana como escolha de vida, pautando decisões profissionais e políticas até os dias de hoje.

\section{1 "PORQUE A DITADURA É QUE ESTÁ ERRADA"348: QUANDO RESISTIR É PRECISO}

As histórias de vida dos quatro narradores, após o golpe de 1964, que implantou no Brasil um regime de exceção de direitos, arbitrariedades e violações de direitos humanos, se assemelham em diversas recordações. Embora não tenham vivenciado essas experiências conjuntamente, dividindo os mesmos espaços ao mesmo tempo, levantaram-se, cada um a seu modo, em face do regime. Conheceram os meios de luta que aquele momento, em sua visão, exigia.

\footnotetext{
${ }^{347}$ Fala de Maurice Politi em entrevista concedida em 10 jan. 2015.

${ }^{348}$ Fala de Ivan Seixas em entrevista concedida em 08 nov. 2014.
} 
Além disso, na mesma cidade, passaram pelas mesmas carceragens, em momentos bem próximos; conheceram a mesma engrenagem da repressão; e, em consequência, foram expostos à mesma ideologia de combate ao "inimigo", sob a qual atuavam os órgãos de repressão. Ao final, foram também testemunhas e atores de um mesmo momento histórico, que marcou toda uma geração de brasileiros, deixando marcas e sequelas até os dias de hoje.

Na linha do que defende Michael Pollak, a memória social é composta não somente do que é pessoalmente vivido e compartilhado, no mesmo tempo e espaço, mas daquilo que foi vivenciado por outro grupo, até mesmo em outra época, mas que foi de tal maneira propagado coletivamente, que também é absorvido pelos demais sujeitos como sendo parte das experiências de cada um. ${ }^{349}$

No presente caso, os quatro narradores vivenciaram as experiências de deparar-se, em plena juventude, com um golpe de Estado que depôs o Presidente da República e instaurou um regime de violações de direitos. Naquele ano, o mais novo dos narradores, Ivan Seixas, ainda nem completara dez anos de idade. A mais velha, Elza Lobo, completaria, dias depois do golpe, vinte e sete anos. Rose Nogueira fazia dezoito e Maurice Politi, quinze. Todos, em algum momento daqueles anos que se seguiriam, decidiram não apoiar o estado de coisas que se fazia presente com a ditadura.

Os narradores compuseram uma resistência política que se fez presente desde a primeira hora do golpe, já em abril de 1964. De certo que boa parte da sociedade apoiou o golpe, mas até a sanção da Lei de Anistia, em agosto de 1979, inúmeras foram as frentes de embate e levante em face do governo de exceção. Formaram algumas frentes de embate e oposição, o movimento estudantil; o movimento cultural e artístico; publicações de jornais clandestinos; o movimento sindical; e o movimento das igrejas. Se pôde considerar igualmente como movimento de reação à ditadura grandes passeatas realizadas por todo o país, com gritos e faixas de denúncia, assim como o protesto em silêncio nos cortejos fúnebres e nas missas. Dentro das prisões, eram utilizadas as greves de fome. A campanha pela anistia mobilizou diferentes núcleos de advogados, estudantes, mães e pais e ativistas. Organismos internacionais enviaram manifestos de apoio à

\footnotetext{
${ }^{349}$ POLLAK, 1992, p. 2.
} 
resistência, rechaço e denúncia contra as violações. ${ }^{350}$

O conjunto das experiências dos quatro narradores reconstitui a composição de um vasto tecido de memória social dos tempos da ditadura. Das suas falas surgem recordações da influência da militância estudantil; do exemplo dentro de casa; da importância do trabalho da imprensa nos tempos de censura; do desejo de defesa dos direitos sociais e de reaver os direitos usurpados pelo governo de exceção; e das experiências nas organizações de resistência, na vida clandestina, na luta armada e no exílio.

Quando eclodiu o golpe de 1964, a militância estudantil, em grande parte pelo desempenho da União Nacional dos Estudantes (UNE), vinha de um período de forte atuação em busca de mudanças sociais e pela democratização da educação no país. Com o golpe, logo a entidade virou alvo da repressão política. E, da mesma forma, todo e qualquer espaço, movimento e reunião no meio estudantil.

Já nos primeiros dias de ditadura, inúmeros eventos em diversas cidades foram cercados e invadidos por policiais e militares, diretórios foram fechados e muitos estudantes e professores foram presos. No final de 1964, a UNE e demais entidades estudantis é extinta por força legal:

Configurado o golpe e nomeado o "Comando Supremo da
Revolução", este tratou de efetuar punições e cassações com a
chancela do Ato Institucional (que ficaria conhecido como Al-1) que
passou a vigorar em 9 de abril. As instituições universitárias se
tornariam, juntamente com sindicatos, alvos da ação repressiva dos
governos militares, considerados locais privilegiados para a difusão
de doutrinas revolucionárias e de recrutamento para as
organizações de esquerda. Logo após o golpe militar, as primeiras
semanas de aula nas universidades foram suspensas e foi
colocada em ação a chamada Operação Limpeza, nome utilizado
por agentes do Estado e seus apoiadores para expressar a
determinação de afastar do cenário público os adversários recém-
derrotados - comunistas, socialistas, trabalhistas e nacionalistas de
esquerda, entre outros.

\footnotetext{
${ }^{350}$ Texto "A resistência da sociedade civil às graves violações de direitos humanos", de autoria da conselheira Maria Rita Kehl e apresentado como anexo ao Relatório Final da Comissão Nacional da Verdade. Disponível em: <http://www.cnv.gov.br/images/pdf/relatorio/Volume\%202\%20\%20Texto\%209.pdf.> Acesso em: 08 jul. 2015.

${ }^{351}$ Texto "Violações de Direitos Humanos na Universidade", de autoria da conselheira Rosa Maria Cardoso da Cunha, extraído do Relatório Final da Comissão Nacional da Verdade. Disponível em <http://www.cnv.gov.br/images/pdf/relatorio/Volume\%202\%20-\%20Texto\%206.pdf>. Acesso em: 05 jul. 2015.
} 
Mesmo sendo alvo de ações que visavam seu domínio e esvaziamento, o movimento estudantil seguiu na clandestinidade, reorganizando-se com mais força a partir de 1966:

[...] passou a realizar protestos e greves, protagonizando uma série de manifestações que acabavam em choques, muitas vezes violentos, com as forças policiais nos diferentes estados. A pauta dos estudantes incluía desde questões mais específicas como a melhora dos restaurantes universitários e o fim dos acordos MECUSAID até a luta mais geral para terminar com a ditadura. [...] Foi no ano de 1966 que a UNE voltou a organizar eleições para sua diretoria, por meio de seu 28 Congresso. Mesmo sendo proibido pela ditadura, os estudantes escolheram a cidade de Belo Horizonte para organização do evento. ${ }^{352}$

O ambiente, no entanto, seguia dominado pelas forças da repressão, também de modo clandestino, por meio da infiltração de agentes entre os estudantes. Por meio dessa atuação, inclusive, muitos militantes, "caíram" nas mãos dos agentes. É a narradora Elza quem explica:

[...] quem me prendeu na minha casa foi o Capitão Maurício do DOI CODI e ele frequentava a USP como se fosse um aluno de geografia. Ele estava no contexto de ver quem eram os alunos, como eram as reuniões. Ele estava infiltrado. E essas situações nem sempre num primeiro momento foram vistas da maneira correta. Naquele tempo você precisava de autorização para entrar no prédio, e o porteiro nem sempre sabia quem é que estava chegando e acabava abrindo a porta do prédio para entrar uma pessoa que estava lá levantando informações e dados. O mesmo acontecia dentro da universidade. Você achava que estava com um colega e ele estava ligado ao esquema todo, ligado ao Fleury, ao DOI-CODI. Até as pessoas perceberem 0 que estava acontecendo... ${ }^{353}$

Foi esse o cenário no qual Elza e Maurice se engajaram na militância estudantil. Ambos reconhecem nas experiências vivenciadas a partir das escolas e universidades que frequentaram naquele momento a influência determinante de seu engajamento na resistência contra a ditadura.

Maurice, por exemplo, teve esta trajetória iniciada já a partir de um ato de rebeldia contra os ideias da própria família. De família conservadora, a escolha do

\footnotetext{
352“Violações de Direitos Humanos na Universidade”, de autoria da conselheira Rosa Maria Cardoso da Cunha, extraído do Relatório Final da Comissão Nacional da Verdade.

${ }^{353}$ Entrevista concedida em 08 nov. 2014.
} 
local onde estudaria o ensino secundário, a contragosto do pai, o colocaria, sem que planejasse, na efervescência da militância estudantil e, ao final, na composição de uma influente e atuante organização de resistência política, a Ação Libertadora Nacional:

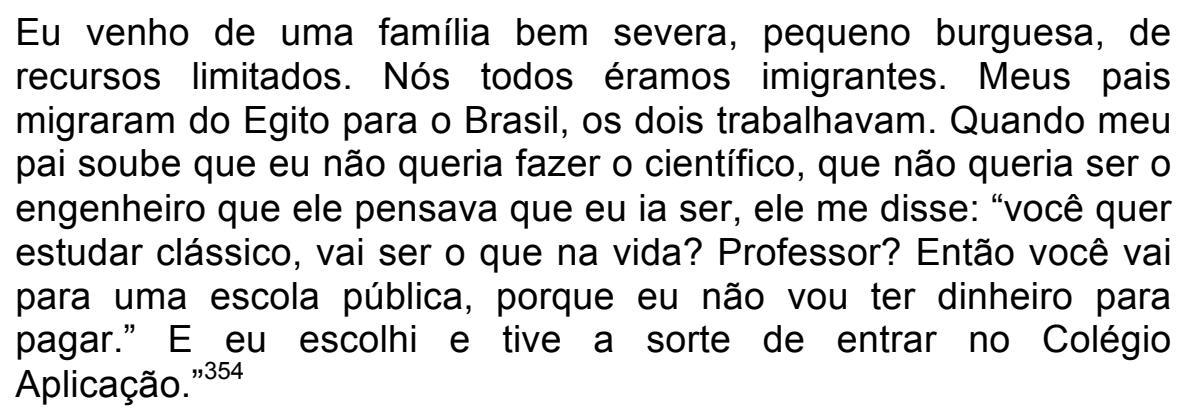

A sorte a que o narrador faz menção, se refere ao início do contato com a juventude militante de oposição à ditadura, por meio de uma escola pública secundarista "muito combativa e que tinha ideais" e cujo lema era "não se guiar pela educação tradicional". Naquela instituição aproximou-se de alunos e professores já ajustados com a resistência à ditadura, dos quais, "muitos, inclusive, tinham sido vetados em universidades" e também "professores que acabaram sendo presos". ${ }^{355}$ Sobre a influência daquele ambiente na sua escolha pela militância política, Maurice não tem dúvida: "Essa escola começou a me despertar para a política. Ali eu comecei a militar no movimento estudantil secundarista apoiando e tocando as manifestações." Dali em diante, trilharia um caminho sem volta, envolvendo-se cada vez mais com a causa da resistência e com a militância organizada.

É também à sua experiência no ensino colegial que a narradora Elza credita seu ingresso na militância de oposição ao governo durante a ditadura. A experiência no Colégio Estadual Fernão Dias Paes, localizado no bairro de Pinheiros, na capital paulista, foi, para ela, "muito marcante" em sua formação. Recorda que lá teve um ensino que privilegiava debates multidisciplinares e onde havia "um envolvimento muito forte dos professores, profissionais que se dedicavam inteiramente à formação dos alunos”. Essa experiência, da qual a

\footnotetext{
${ }^{354}$ Entrevista concedida em 08 nov. 2014.

${ }^{355}$ Entrevista concedida em 10/01/2015.
} 
narradora sente-se orgulhosa, parece tê-la marcado de uma maneira muito forte, de modo que atribui a ela o compromisso assumido com as questões sociais no passado e também no presente, tendo a educação como ponte entre esses diversos tempos de suas experiências de vida: durante a ditadura, optou pela atuação junto a programas de erradicação do analfabetismo, posteriormente, decidiu formar-se em Educação.

A fala de Elza, ao lembrar da experiência escolar, é carregada dos sentimentos nostálgicos de saudade e lamento. Saudade do tempo em que a educação contava com o compromisso dos profissionais e lamento por não ser esse o cenário atual da educação, na sua concepção:

Não temos mais colégios com esse perfil de envolvimento dos
profissionais como naquela época. Eu resgato isso, porque acho
que é importante a gente ter uma memória do passado. [...] Essa
caminhada são situações que hoje você não tem na formação dos
cursos. Esse lado foi o que se trouxe para que se tenha uma outra
visão de mundo e outra visão de como você pode estar, nos
diferentes momentos, se envolvendo nas atividades. Então essa
formação do Fernão Dias Paes, naquela época, foi muito
importante.

Foi neste clima, que, enquanto a militância estudantil secundarista já ocupava grande parte da vida de Maurice, ele ingressou em um curso prévestibular chamado à época de "Pré-USP", no ano de 1967. Ali, o narrador se viu em um espaço repleto de militantes políticos, em especial, "militantes que depois vieram a ser assassinados e foram presos", mergulhando ainda mais na oposição ao regime de exceção:

A gente não sabia. Entrava nesse cursinho porque era o mais barato. $E$ foi onde tínhamos professores que eram todos militantes. [...] Pouca gente soube da sua existência porque, depois de dois anos, com as prisões que ocorreram, ele foi fechado. Na verdade, era uma forma de viabilizar a vida de certos militantes que estavam na clandestinidade e de ter acesso à juventude e fazer proselitismo político, engajar as pessoas no movimento e tal [...] esse cursinho Pré-USP já era de gente ligada ao Marighella. ${ }^{357}$

Seguindo a vida nos ambientes acadêmicos, Elza ampliou sua atuação voltada às questões sociais, enquanto cursava Jornalismo e Educação, na

\footnotetext{
${ }^{356}$ Entrevista concedida em 08 nov. 2014.

${ }^{357}$ Entrevista concedida em 10 jan. 2015.
} 
Faculdade Casper Líbero e na Universidade de São Paulo (USP), respectivamente. Lá tocava trabalhos de alfabetização de adultos, entre os anos de 1964 e 1965:

Nós tivemos uma presença muito forte de juntar alguns setores. Juntar o SESC com a Folha de São Paulo e fazer um evento grande no litoral, em Ubatuba, levando os jovens de diferentes escolas para participarem desses grupos de alfabetização. Fomos quase em torno de 200 alunos que fomos para lá dar o curso de alfabetização, de fazer um trabalho muito intenso, mesmo já começando o período autoritário, em torno de 64, 65. Como tínhamos os órgãos internacionais também junto, nós tivemos a possibilidade de formar essas turmas e começaram a fazer grupos de alfabetização em diferentes cidades e diferentes locais. Foi uma caminhada muito significativa. ${ }^{358}$

Quando ingressou na Faculdade de Comunicação da USP, Maurice ampliou ainda mais sua militância política, sendo eleito, em 1968, vice-presidente do grêmio estudantil. Nesta época envolveu-se na luta pela ampliação de vagas na Universidade, razão pela qual sofreu seu primeiro processo de caráter administrativo:

Não foi um processo policial, mas foi onde meu nome já apareceu aqui no DOPS. O processo não deu em nada. Na época, quem foi meu defensor no processo administrativo, foi o Dalmo Dallari. O Dalmo era professor iniciante na Faculdade de Direito e foi me defender, porque quem tinha me acusado era outro professor, conhecido de direita, ligado aos militares. Então ele foi para fazer a contraposição e conseguiu me absolver dizendo: "Olha, não tem prova. Ninguém viu ele distribuindo panfleto." Mas isso passou. Isso foi em 68 e continuei minha militância. ${ }^{359}$

Era um período de ampliação dos encontros e manifestações estudantis em todo o país e, em consequência, do recrudescimento da repressão. Nesse momento a USP retomava a pauta da reforma universitária, houve a "batalha da Maria Antônia" ${ }^{360}$, e o Congresso de Ibiúna, episódio marcado por uma intensa investigação policial que culminou com a prisão de cerca de 700 estudantes $^{361}$.

\footnotetext{
${ }^{358}$ Entrevista concedida em 10 jan. 2015.

${ }^{359}$ Entrevista concedida em 10 jan. 2015.

360 "na qual um grupo paramilitar do Comando de Caça aos Comunistas, formado em parte por estudantes da Universidade Mackenzie, com a proteção de forças policiais, invadiu o prédio da Faculdade de Filosofia da USP, depredando instalações e agredindo seus ocupantes. No confronto, foi morto o estudante secundarista José Carlos Guimarães e várias pessoas foram feridas." Texto CNV.

361 “Em um episódio bastante conhecido de 12 de outubro, a polícia cercou e prendeu cerca de 700 estudantes em Ibiúna, durante o 30 o Congresso da UNE. Tão logo começou a movimentação pela organização desse congresso, no segundo semestre de 1968, o DOPS São Paulo montou uma
} 
Este último episódio se deu quando Maurice era vice-presidente do grêmio estudantil na USP, ocasião em que muitos de seus companheiros foram presos. Neste momento, o narrador recorda que atuava em parceria com a atual Presidenta do Brasil: "Fui eleito vice-presidente junto com uma pessoa que está hoje em Brasília, que é nossa Presidenta e ela acabou indo para Ibiúna, porque ela era a presidente e então eu acabei não indo para lbiúna."

O ingresso de Rose Nogueira na resistência à ditadura surge em sua fala de modo relacionado ao sonho de ser jornalista. Com 18 anos de idade, na ocasião do golpe de 1964, a narradora encantava-se com a ideia de trabalhar no jornal Última Hora, ligado ao Partido Trabalhista Brasileiro (PTB), do presidente deposto João Goulart. Tinha pressa e queria logo entrar em prática:

E seria bom que você fizesse sociologia ou entre na USP e faça história, filosofia, humanas... Mas eu disse: "eu quero agora, porque eu quero trabalhar e eu só quero ser jornalista." Eu nem sabia o que era pauta. Meu sonho não era só ser jornalista, era trabalhar na Última Hora, que era do PTB. Porque eu peguei toda essa herança. ${ }^{362}$

Quando apoiava as lutas de oposição ao regime de exceção, Rose já trazia consigo o ideal de luta pelas causas sociais. Durante quase toda a entrevista a narradora volta à história de vida de sua família, evocando, especialmente, a influência de seus avós. Nesses momentos é interessante a relação que faz entre afeto e luta pelas causas sociais. Para a narradora, parece que ambos estão inevitavelmente ligados:

operação, em conjunto com as polícias da Guanabara, Minas Gerais, Paraná e Rio Grande do Sul, entre outros estados, para acompanhar e desbaratar o evento estudantil. Assim foi lançada a Operação Ibiúna, 50 que ocorreu em três fases, a saber: a primeira, antes do evento, onde agentes infiltrados produziam informações sobre a realização do congresso. A segunda foi a ação da prisão ilegal dos estudantes: 95 investigadores do DOPS/SP participaram da ação coordenada pelos delegados José Paulo Bonchristiano (adjunto da Ordem Política) e Orlando Rozante (adjunto da Ordem Social), e, por fim, o inquérito propriamente dito. Após a decretação do Ato Institucional no 5 (Al-5), em 13 dezembro, um último episódio encerrou o ano universitário de 1968. Em 17 de dezembro, a Cidade Universitária da Universidade de São Paulo foi invadida e seu conjunto residencial (Crusp) foi ocupado por forças policiais e militares. No Crusp foram presos - e liberados aos poucos - cerca de 800 estudantes. Cerca de 1.400 estudantes que lá residiam foram desalojados. Houve protestos formais do vice-reitor em exercício e do Conselho Universitário. Logo depois foi aberto um IPM específico sobre o Crusp,51 com o indiciamento de 43 estudantes." Texto "Violações de Direitos Humanos na Universidade", de autoria da conselheira Rosa Maria Cardoso da Cunha, extraído do Relatório Final da Comissão Nacional da Verdade, p. 275. Disponível em <http://www.cnv.gov.br/images/pdf/relatorio/Volume\%202\%20-\%20Texto\%206.pdf>. Acesso em: 05 jul. 2015.

${ }^{362}$ Entrevista concedida em 07 nov. 2014. 
Tinha um avô anarquista que me ensinava muita coisa. Eu tenho essa formação familiar que não é acadêmica e me fez estudar. [...] E eu tinha uma avô anarquista e uma avó sindicalista. Tudo que eu era estava ali dentro. [...] Embora meu padrasto tenha me colocado desde menina em uma escola de freiras, eu sempre ouvia muito a minha avó e as histórias da classe operária, no bairro Ipiranga, eu morava lá. Para mim, tudo aquilo tinha a ver com os ensinamentos cristãos de amor ao próximo, de caridade. [...] Igreja fala de caridade. E bondade, obrigatórios. Eu achava tudo muito parecido $^{363}$

Na prática das edições dos jornais, naqueles anos de intensa censura, Rose foi conhecendo e trabalhando com diversos militantes políticos. Conviveu com militantes que acabaram sendo assassinados e outros que permanecem desaparecidos. Foi nesse meio que casou com o também militante de oposição, Luiz Roberto Clouset, e passou a conviver com muitos militantes, inclusive, com Carlos Marighella:

Fui junto com os companheiros dentro da coisa muito mais de conhecimento, de leituras. A gente ia até em almoços, do que propriamente de luta. Até que em 67 o Marighella lá na reunião da OLAS saiu do Partidão e propôs uma luta mais direta e armada e eu achei justo. Eu não integrei imediatamente. [...] Me casei com o Clouset na igreja dos dominicanos que já tinham se aproximado das lutas contra a ditadura. Eu já estava na Folha da Tarde, jornal. Meu chefe era o Frei Betto, chefe de reportagem e meu editor ela o Luiz Roberto Clouset. Trabalhava lá o Merlino, que foi morto em $71 .^{364}$

A entrada de Ivan Seixas na militância política deu-se por influência direta de sua família. Seus pais, Joaquim de Alencar Seixas e Fanny Akselrud Seixas, se conheceram na militância por meio do Partido Comunista, na cidade do Rio de Janeiro, e ajudaram a fundar, no Rio Grande do Sul, a organização Movimento Revolucionário 26 de Março (MR-26). Mais tarde, em 1970, atuam no Movimento Revolucionário Tiradentes (MRT), já na cidade de São Paulo. Nesta altura, já com 16 anos, Ivan também integrava o grupo.

Quando fala de sua experiência de militância política, o narrador traz a influência do pai, defensor da "honestidade, não violência e respeito às leis". Neste momento de sua fala aponta para a contradição de ter este mesmo homem

\footnotetext{
${ }^{363}$ Entrevista concedida em 07 nov. 2014.

${ }^{364}$ Entrevista concedida em 07 nov. 2014.
} 
escolhido pela luta armada como meio de combater à ditadura. Na sua visão, naquele momento, a resistência era uma obrigação, um dever cívico de se erguer contra um governo ilegítimo e usurpador, que, como tal, deveria ser combatido. $\mathrm{E}$, nesse sentido, o narrador se viu obrigado a tornar-se um soldado. Entende, ainda, que, não fosse aquela situação imposta pelo regime de exceção, certamente teria seguido os caminhos do pai, tornando-se também um operário. Mas, aos 16 anos de idade, viu-se um soldado clandestino. Na sua visão, esta foi a maior crueldade que a ditadura poderia ter feito com os cidadãos:

Meu pai era um mecânico. Virou um guerrilheiro. Eu, filho de um mecânico, ia ser mecânico ou um operário de outra coisa qualquer e me transformei num guerrilheiro. Foi uma violência muito grande. Imagina o que é um cara que está acostumado com chave inglesa, peças de motor, de repente está com um fuzil na mão, que ensinou para o filho honestidade, não violência, respeito às leis. Meu pai, apesar de comunista, sempre fez isso: "existe a lei, você tem que respeitar." E de repente fala assim: "Nós vamos assaltar um banco, nós vamos sequestrar, vamos fazer sei mais o quê. Por causa da causa, porque a ditadura é que está errada. Então nós temos que inverter." Então foi uma grande violência. ${ }^{365}$

A atuação de resistência por meio de organizações de esquerda tornou-se o caminho alternativo para manter atividades políticas e também a sobrevivência da militância de oposição ao regime. Entre os narradores, todos os quatro caíram na mira da repressão pela atuação em três organizações: ALN, AP e MRT.

As prisões de Maurice e Rose, por exemplo, se deram no período em que a organização na qual atuavam, ALN, era objeto de uma verdadeira caça aos militantes da luta armada e quando a organização foi praticamente dizimada. ${ }^{366}$

Já no início de sua fala, Maurice nos coloca à par de sua primeira prisão, quando traz à tona sua atuação na ALN:

Em 68 e 69 comecei a me envolver com o pessoal que depois formou a ALN. Na verdade, esse cursinho Pré-USP já era gente ligada ao Marighella. A Ação Libertadora Nacional se chamava Agrupamento Comunista de São Paulo. Quando o Marighella saiu do partido ele formou o Agrupamento Comunista de São Paulo. ${ }^{367}$

\footnotetext{
${ }^{365}$ Entrevista concedida em 08 nov. 2014.

${ }^{366}$ Mais informações sobre Carlos Marighella e a ALN no livro "Rádio Libertadora: a palavra de Carlos Marighella" / Organizadora lara Xavier Pereira. Brasília: Ministério da Justiça. Comissão de Anistia, 2012, p.113.

${ }^{367}$ Entrevista concedida em 10 jan. 2015.
} 
O narrador percorre com detalhes sua atuação junto à organização, na qual esteve "sempre atuando na legalidade". O adjetivo, para Maurice, se justifica pela atuação de "fachada" que mantinha para permitir que outras ações pudessem ser desempenhadas. Esclarece que o modus operandi da organização exigia tanto quem atuasse clandestinamente na linha de frente da luta armada, opção de atuação da ALN, quanto quem atuasse nos bastidores, de modo a dar todo o suporte necessário às ações da organização, como era sua posição. Nessa empreitada, seguia como estudante da USP acima de suspeitas enquanto utilizava diversas identidades para alugar carros e casas e transportar documentos que permitissem a mobilidade de outros militantes clandestinos:

Eu já estava com pessoas que militavam na Ação Libertadora Nacional e comecei a trabalhar no apoio logístico. Nunca fiz parte de grupo armado, embora a ALN fosse pela luta armada e tivesse o chamado GTA - Grupo Tático Armado, eu não fazia parte do GTA. [...] Então comecei a me envolver com 19 anos, ter todo apoio e fazendo coisas banais. Assim banais [...] eu comprei vários carros. [...] Ou precisava levar um passaporte para uma pessoa que estava no esquema de saída, igual o pessoal que saia pelo Sul. [...] A gente levava a pessoa perseguida, uma pessoa militante, clandestina, mas muitas vezes eles ficavam lá esperando a documentação falsa. Alguém tinha que levar a documentação falsa. Várias vezes eu me lembro de pegar ônibus ou avião e ir para Porto Alegre, sem saber quem era a pessoa. Depois que eu fiquei sabendo. Então, eu fazia esse tipo de apoio à organização. Sempre atuando na legalidade. ${ }^{368}$

A dedicação do narrador às atividades na ALN já ocupava quase que de modo exclusivo sua vida:

Eu mantive, até minha prisão, minha vida legal como estudante. Pouco estudava, mas oficialmente era estudante da USP e ia ajudando na logística da organização. Na época eu tinha muito contato não com o Marighella, mas com o Joaquim Câmara Ferreira que era o segundo, e ele sempre me dizia que havia necessidade de ter gente clandestina para pegar em armas e os outros que fossem legais que pudessem alugar um apartamento, comprar um carro. E eu fazia isso. ${ }^{369}$

Foi também pelo suporte logístico à ALN que Rose foi presa, estando ligada diretamente a seu dirigente:

\footnotetext{
${ }^{368}$ Entrevista concedida em 10 jan. 2015.

${ }^{369}$ Entrevista concedida em 10 jan. 2015.
} 
O que a gente podia fazer era oferecer nossa casa, para reuniões, para o que eles precisassem. Aí a gente foi preso por isso. Teve algumas reuniões na minha casa. Conheci o Marighella, dormia algumas vezes lá em casa. Prenderam os dominicanos e a eles levaram a polícia lá em casa. ${ }^{370}$

A prisão de Ivan pelo envolvimento com a organização MRT traz também em sua fala a experiência com a luta armada, a clandestinidade e os nomes falsos. Nesse momento, aponta detalhes de atuação por meio da organização, que realizava assaltos a bancos como forma de financiar sua atuação.

Ao falar da vida clandestina, expõe a situação de tensão, na qual qualquer passo dado fora do lugar significava pôr a vida em risco, representando para ele "um negócio sufocante", "uma violência":

Viver clandestino é você ter dois nomes. Se alguém chamar Ivan eu não posso virar a cabeça porque eu posso denunciar que eu sou o Ivan. E se alguém chamar meu nome de guerra eu não posso virar a cabeça também porque eu posso estar sendo vigiado e querem saber se eu sou aquele lá. $E$ quem tinha documento falso, tinha três nomes. O nome verdadeiro, o nome da carteira de identidade falsa e o nome de guerra. $E$ você não pode atender nenhum dos três. $A$ sua cabeça tem que ser condicionada a descondicionar dessa coisa do reflexo, se não você pode se trair e você pode morrer. [...] Eu não acho que é uma coisa agradável e eu não vou pregar uma vida dessa forma. Eu acho que é um horror isso. ${ }^{371}$

Ao mesmo tempo em que vê a vida clandestina de "Teobaldo", seu nome de guerra, como uma necessidade daquele momento histórico, Ivan também afirma com clareza que aquele tipo de atuação pertence ao passado:

Eu sou Ivan, né. Eu sempre fui Ivan. E num determinado momento eu fui Teobaldo. Eu não posso ser Teobaldo hoje. Não existe isso. Teobaldo é um personagem da história que eu encarnei porque era um dever cívico e patriótico fazer isso. Hoje eu tenho o dever cívico e patriótico de contar sobre o Teobaldo e dizer que ele fique no passado. Saibam que ele aconteceu, mas ele está lá. Não é para repetir. ${ }^{372}$

Dessas escolhas de vida dos narradores parece ter restado um sentido bem uníssono nas suas memórias: nada de remorsos ou arrependimentos. Ao contrário,

\footnotetext{
${ }^{370}$ Entrevista concedida em 07 nov. 2014.

${ }^{371}$ Entrevista concedida em 08 nov. 2014

${ }^{372}$ Entrevista concedida em 08 nov. 2014.
} 
suas falas deixam transparecer a insurgência contra a ditadura como o único caminho possível diante do quadro de necessária retomada da democracia.

Na visão de Maurice, por exemplo, tratou-se de uma escolha individual com total compreensão das consequências que possivelmente se seguiriam. Para o narrador, havia uma consciência do ônus da decisão de combater a ditadura: "Nós não somos nem heróis, nem vítimas. Nós sabíamos onde estávamos, onde estava o problema. Sabíamos dos perigos. Enfrentamos, alguns não sobreviveram, nós sobrevivemos. Por tanto, essa foi a forma que nós encontramos de resistir a um período." 373

Para ele, vítima é alguém despreparado, que não sabe das possíveis consequências de seus atos. Completando seu raciocínio, afirma que herói é o "moço que segura o bebê que cai do prédio." Está igualmente desavisado do que está acontecendo e acaba por fazer o inesperado. Falando no plural, em referência à coletividade de militantes, Maurice entende que os resistentes políticos não se encaixariam em nenhuma dessas duas categorias.

A narradora Rose também expressa sua indignação com uma possível vitimização de quem atuou na resistência política. É ela que se recusa, inclusive, a ser tratada como ex-presa política, de modo a despertar o sentimento de pena.

No caso de Ivan, a escolha pela luta armada, foi sim uma obrigação cívica, mas revestida de uma violência sem igual, imposta pela própria ditadura, à medida que obrigou os resistentes a desfazerem planos e caminhos para, ao final, tornarem-se combatentes. Para ele, a violência de transformar cidadãos em soldados, à medida que tinham o dever de lutar para retomar a democracia, superou as violências físicas, sendo mais forte que violência do eletrochoque. Obrigá-los a esse papel foi, na sua visão, a violência mais forte deixada pela ditadura.

Nem todas as experiências do passado merecem ser repetidas. Quando se fala em reconstituí-las em diálogo com o presente, é preciso reconhecer cada contexto e suas respectivas necessidades. É dessa forma que deve se dar o processo de reflexão política a partir de vivências: analisando cada contexto.

É com esta noção que o narrador Ivan recorda seu envolvimento com a luta

\footnotetext{
${ }^{373}$ Entrevista concedida em 10 jan. 2015.
} 
armada. Entende, e deixa claro, que este meio de oposição foi importante para a conjuntura política da época, sem, no entanto, apostar neste tipo de atuação nos dias de hoje:

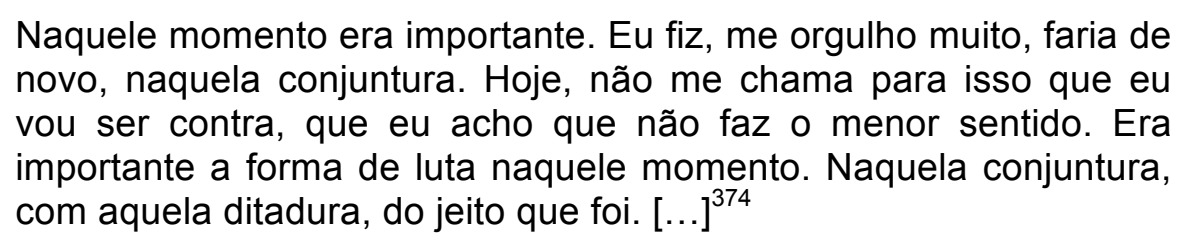

Com o passar do tempo, Ivan mantém-se acreditando na luta por uma vida mais digna e igualitária, mas acredita que os meios para isso são outros, como o diálogo que mantém com os jovens por meio do Memorial da Resistência: "Naquele momento eu defendi sequestro, justiçamento, defendi e defendo até hoje o que foi feito. Mas não defendo fazer hoje. Porque hoje é democracia." 375

\section{2 "UM CAMINHO DE SEMPRE PENSAR NOS OUTROS"376. ENTRE PERDAS, INCERTEZAS E DORES, VENCEU A SOLIDARIEDADE.}

As escolhas que os quatro jovens fizeram, naqueles anos da década de 1960, os levaram, cada um em determinado momento, a conhecer o peso dos órgãos de repressão, a vida no cárcere, na clandestinidade e no exílio. A partir das lembranças deste período, é possível conhecer o espaço das carceragens, o funcionamento do aparato repressor no Estado, além dos significados de dor, perda, incertezas e, também, afeto e solidariedade entre os companheiros.

De um modo geral, quando as narrativas mergulham nesses tempos de suas vivências, entre as prisões e o fim da ditadura, muitas informações deixam de ser ditas diretamente pelos narradores. Elza Lobo, por exemplo, não fala de sua atuação na AP - Ação Popular Marxista Leninista, razão que a pôs na mira dos órgão da repressão. Ivan não traz à tona, por exemplo,as horas que sucederam sua prisão, a morte do pai nas primeiras horas da prisão, os momentos de intensas torturas, nem os atentados que simularam sua execução, o período de

\footnotetext{
${ }^{374}$ Entrevista concedida em 08 nov. 2014.

${ }^{375}$ Entrevista concedida em 08 nov. 2014.

${ }^{376}$ Fala de Elza Lobo na entrevista concedida em 08 nov. 2014.
} 
incomunicabilidade ou os gritos que ouvia vindas das torturas de sua mãe e irmãs. ${ }^{377}$

No tema em estudo, em especial, é primordial lembrar que o silêncio é, antes, fruto de uma cultura de dominação, como lembra Ecléa Bosi ${ }^{378}$, nos remetendo, ainda, à memória subalterna tratada por Michael Pollak. Afinal, foram muitos os anos de repressão direta e outros tantos de vozes sufocadas.

Neste aspecto, Pollak (1989, p. 5) nos lembra que:

O longo silêncio sobre o passado, longe de conduzir ao esquecimento, é a resistência que uma sociedade civil impotente opõe ao excesso de discursos oficiais. Ao mesmo tempo, ela transmite cuidadosamente as lembranças dissidentes nas redes familiares e de amizades, esperando a hora da verdade e da redistribuição das cartas políticas e ideológicas.

Ainda, como ensina Bosi (2003, p.64), as omissões em história oral não significam necessariamente fracasso na coleta ou análise das narrativas. Ao contrário, insegurança e não linearidade, fala emotiva e fragmentada, conferem à fala o "selo de autenticidade"379

Quando se trata de lembranças traumáticas, a autora fortalece ainda mais seu discurso no sentido de reafirmar as hesitações, incertezas e silêncios não como vazios, mas sim "trabalhos da memória", indicando, inclusive, o próprio absurdo da experiência: "O eclipse da palavra advém da destruição: - do espaço biográfico das vítimas, - da própria pessoa, - da sua memória" (BOSI, 2003, p.64).

A tortura, sem sombra de dúvidas, um método já bastante utilizado contra presos comuns no Brasil, ganhava contornos de profissionalização com a repressão política pós-1964. Não seria ilação ou irresponsabilidade afirmar que praticamente todos os presos políticos sofreram algum tipo de tortura. Muitos são os relatórios, desde o "Brasil Nunca Mais" publicado em meados da década de

\footnotetext{
${ }^{377}$ Essas informações busquei no depoimento de sua própria mãe no Relatório da CNV p. 411: "Além de ter sido barbaramente torturado, assistiu ao início das torturas que culminaram com a morte de seu pai. Embora cessadas as torturas físicas - pau de arara, choques elétricos nos órgãos genitais, ouvidos, língua, etc. -, as torturas psicológicas duram até hoje, com idas ao DOI-CODI e DEOPS, para novos espancamentos e ameaças de morte. Depois de seis meses de incomunicabilidade ilegal, passou então Ivan à custódia da Justiça Militar."

${ }^{378} \mathrm{BOSI}, 2003$, p.64

${ }^{379}$ Como muito de suas experiências restaram registradas em outras fontes, pude delas me valer para complementar a compreensão dessas experiências.
} 
1980, até o mais recente relatório final da Comissão Nacional da Verdade, de 2014, em que a tortura é relacionada como prática corrente na política de segurança do Estado durante a ditadura.

As experiências dos narradores neste sentido emergem de modo bem sutil em suas falas. Não são eles que me contam os detalhes das violações que sofreram. ${ }^{380} \mathrm{O}$ silêncio, aqui, pode conter vários significados, cabendo, por ora, tão somente identificá-los e contextualizá-los. Podem representar justamente o contrassenso trazido por Bosi, dado o absurdo da própria vivência, como se poderia dizer da experiência de cárcere da narradora Rose, que é capaz de falar das torturas e humilhações sofridas pelos negros escravizados, mas não traz na sua fala os detalhes das sevícias que sofreu no DEOPS. Ela nada me fala das experiências com a equipe do delegado Fleury no período de puerpério, onde sua condição de mulher que acabara de dar à luz era usada para tornar ainda mais dolorosa a tortura. No entanto, bem no início da entrevista, a narradora conta que foi presa em casa logo após o nascimento de seu filho e fala abertamente de uma de suas sequelas, dando a conhecer o modo como a repressão fazia uso da condição das presas mulheres como meio de impingir-lhes ameaças e torturas psicológicas específicas a sua condição:

Naquela época eu tinha um bebê de um mês. [...] Esse é meu filho
que a ditadura ameaçou tanto. Que a ditadura levou lá para me
ameaçar. Então eles acabaram, eles foram em cima do melhor que
a gente tinha no Brasil. Então isso aconteceu comigo. Depois eu
não pude ter outros filhos, eu fiquei estéril. ${ }^{381}$

Outra razão para o silêncio sobre as experiências traumáticas vem da fala de Ivan. Ao tratar dos diálogos com os jovens, o narrador demonstrou expressamente o incômodo em falar sobre as violações sofridas. Sua justificativa foi, no entanto, relacionada ao desejo de "elevar" a conversa para questões de cunho mais político, fugindo agora da curiosidade sobre o modus operandi do Estado e as sensações pessoais do torturado. Para o narrador, falar sobre essas

\footnotetext{
${ }^{380}$ Busquei maiores informações sobre as violações que atingiram os quatro narradores em outras fontes. Todos os narradores, em algum outro momento de sua trajetória pós-ditadura, contaram essas experiências, sejam em processos administrativos ou judiciais, publicações de livros e documentários e outras entrevistas.

${ }^{381}$ Entrevista concedida em 07 nov. 2014.
} 
questões é responder a uma demanda de mera curiosidade e ele parece compreender que o momento atual pede um maior aprofundamento no interesse sobre as experiências do passado.

Maurice e Elza, quando perguntados sobre suas experiências durante a ditadura e prisão, também não falam das torturas sofridas. Talvez, como dito por Ivan, também já estejam cansados de repetir essas histórias e sintam a mesma necessidade de aproveitar o ouvinte para trazer outra abordagem, mais voltada à superação.

Mesmo não trazendo à tona detalhes das violências sofridas, os quatro narradores reconstituem as sensações sentidas no cárcere. Surgem o abandono, a falta de proteção e a fragilidade, trazidas pelo narrador Ivan Seixas:

A característica maior da tortura é expressa numa frase que os
torturadores falavam, e que eu acho que falam até hoje: "Aqui o
filho chora e a mãe não vê. Eu posso tudo com você. Se eu quiser
te matar, eu mato. Se eu não quiser te matar, você vai pedir para
morrer e eu não vou te matar." Essa ideia de "aqui o filho chora e a
mãe não vê" é a sensação maior de abandono. Você fica
desprotegido, o homem ou a mulher, está nu, na mão daqueles
monstros que podem tudo. Você está totalmente fragilizado.

Nas palavras de Elza, surgem as humilhações a que eram submetidos os presos políticos no caminho até a Auditoria Militar:

O que era feito? Era feito você ir em uma tanqueta de guerra e quando chegava na Auditoria, na Brigadeiro Luiz Antônio, eles fechavam a avenida e o público ficava ali. Quando a tanqueta chegava abria aquela tampa, você saia por cima e o público começava a gritar "Terrorista, terrorista!", que era uma forma agressiva de depreciar as pessoas. [...] Você chegava lá e não tinha sessão. Eles te deixavam no fundão, não tinha absolutamente nada, você passava às vezes praticamente a tarde inteira lá para depois no fim da tarde voltar outra vez para o Presídio. Que era uma forma de agredir. Então esse lado a gente mexeu muito. ${ }^{383}$

Embora já se soubesse muitos detalhes dessas práticas violadoras de direitos humanos durante a ditadura, a sistematização das torturas praticadas pelos agentes da repressão foi objeto do Relatório final da Comissão Nacional da Verdade, publicado no final do ano de 2014. As práticas foram identificadas em

\footnotetext{
382 Entrevista concedida em 08 nov. 2014.

${ }^{383}$ Entrevista concedida em 08 nov. 2014.
} 
diversos depoimentos e documentos como ação habitual dos agentes da repressão, em todos os órgãos da repressão, deixando de modo claro o conhecimento e a anuência de seus comandos, das Forças Armadas e da Presidência da República. Dentre os espaços que se prestaram a essas práticas, encontra-se também oficialmente o DEOPS/SP:

37. Os registros da prática de violência sexual por agentes públicos indicam que ela ocorria de forma disseminada em praticamente toda a estrutura repressiva. Nos testemunhos analisados pelo grupo de trabalho "Ditadura e Gênero" são citados DEIC, DOICODI, DOPS, Base Aérea do Galeão, batalhões da Polícia do Exército, Casa da Morte (Petrópolis), Cenimar, CISA, delegacias de polícia, Oban, hospitais militares, presídios e quartéis. E, como se pode depreender dos testemunhos recebidos pela CNV e dos documentos analisados, foram múltiplos os tipos de tortura sexual praticados durante a ditadura. $O$ desnudamento forçado era regra: acontecia em praticamente todas as ocasiões que um perseguido político ingressava em um órgão da estrutura da repressão. 38. Da mesma forma, eram constantes as ameaças de caráter sexual ou de gênero e suas práticas. Além disso, há registros de introdução de objetos (principalmente fios elétricos) ou animais na vagina ou ânus dos presos políticos, utilização de presilhas nos órgãos genitais e casos em que o pênis foi amarrado para impedir a vítima de urinar. Nessas sessões, foram utilizados como instrumentos de tortura produtos e objetos disponíveis no dia a dia como ácido, álcool, alicate, canivete, faca, vela e cigarro acesos, cabo de vassoura, corda, além de insetos e animais como barata, rato, cobra, jacaré, bastão elétrico, máquina para aplicação de choques elétricos, cassetete e até mesmo furadeira. ${ }^{384}$

Embora as diferentes técnicas de tortura tenham sido utilizadas indiscriminadamente nos diversos órgãos, o Relatório da CNV, cita expressamente alguns exemplos de casos identificados como ocorridos nas dependências do DEOPS/SP. Segundo o Relatório foram praticadas naquelas carceragens todo tipo de violência sexual e de gênero, em que "a feminilidade e a masculinidade foram mobilizadas para perpetrar a violência, rompendo todos os limites da dignidade humana" ${ }^{385}$. Há relatos em que os agentes ameaçavam a filha pequena de uma presa; em outro caso, uma presa grávida foi torturada até abortar; e, ainda, casos em que as presas eram expostas nuas na frente de diversos policiais e, por vezes, obrigadas a fazer performances de dança.

\footnotetext{
${ }^{384}$ Relatório CNV p. 421

${ }^{385}$ Relatório CNV p. 402 , vol. 1.
} 
Imputações de casos ocorridos na "fortaleza vermelha" ${ }^{386}$ do prédio do DEOPS/SP, dão notícia de órgãos genitais masculinos sendo amarrados por cordas e também a introdução de objetos juntamente com a ameaça de "castração"; choques elétricos e usos de alicates nas genitálias e estupros.

Enquanto no caso dos homens buscava-se ferir sua virilidade, no caso das mulheres havia o tom pejorativo de insinuações sobre sua "honra". Esposas e filhas de presos eram ainda usadas como ameaça de sequestro e estupro. A nudez era usada corriqueiramente como ferramenta de torturas psicológicas, assim como a violação sexual na presença do companheiro. ${ }^{387}$

A condição de mulher dava margem, ainda, às humilhações diferenciadas às presas de modo a denegrir sua participação na vida política, como relatado à CNV, em episódio ocorrido no DEOPS/SP:

Nós recebemos um sermão. Ele [delegado] disse: "vocês são moças, jovens, que provavelmente pretendem casar, constituir uma família, e fica muito mal, moças como vocês estarem frequentando sindicato, estarem metidas nesse tipo de coisa, então vocês vão para casa, tenham juízo e nunca mais se metam nessa." 388

Embora não traga isso em sua fala, as torturas as quais Rose foi submetida, por exemplo, foram potencializadas pela falta de cuidados médicos e de higiene adequada à sua condição de puerpério. A ela foram negados, por exemplo, cuidados com a lactação:

Agora eu estava com infecção, né? E infecção puerperal. Eu me
sentia muito mal, muito mal. Tinha febre, pedia remédio. Os caras
não traziamnada. Quando recebi prisão preventiva, e me levaram
para o Tiradentes, junto com o Clauset, eu não sei se foi minha
família, ou quem foi, que chamou o meu médico, que fez o meu
parto [...] Ele falou: é infecção puerperal. Infecção puerperal. Ela
precisa de antibiótico já. Imediatamente. Aí, tomei um monte de
antibiótico, que ele mesmo deixou lá, segundo as carcereiras [...]
Eu melhorei, só que nunca mais eu engravidei. ${ }^{389}$

As torturas sofridas pela narradora durante o tempo de prisão política, que durou, segundo suas lembranças, nove meses, por ser carregada do sadismo em

\footnotetext{
${ }^{386}$ Expressão utilizada por Frei Betto para se referir ao DEOPS, cuja fachada é de tijolos vermelhos. No livro Batismo de Sangue de sua autoria (p. 249).

${ }^{387}$ Relatório CNV p. 403-404, vol.1.

${ }^{388}$ Relatório CNV p. 405,vol. 1.

${ }^{389}$ Relatório CNV p. 422.
} 
face de sua condição de mulher e de mãe, são emblemáticas e voltam à tona no relato prestado à Comissão Nacional da Verdade:

Eles diziam: "Onde já se viu! Acabou de parir e tem esse corpo! É porque é uma vaca terrorista”. [...] Aí começaram a me chamar de Miss Brasil, porque tinha uma vaca de verdade, leiteira, que ganhou um prêmio [...] Uma vaca chamada Miss Brasil, a vaca ganhou um prêmio. Um daqueles caras, o Tralli, trouxe um jornal que mostrava a vaca e rasgava o jornal e passava em mim. Outra coisa é que eles me tiravam a roupa [...] tinha uma escrivaninha e eles me debruçavam nua com o bumbum para cima e eles ficavam enfiando a mão. Penetração, não tive [...]. Ele me beliscou inteira, esse Tralli. Ele era tarado. ${ }^{390}$

O estado de puerpério, no qual se encontrava quando presa, fase em que a mulher está mais vulnerável física e mentalmente, foi também aproveitado pelos agentes do DEOPS/SP para torturá-la, como contou à CNV:

Veio um enfermeiro logo depois, pra me dar uma injeção pra cortar o leite. Porque esse Tralli [torturador] dizia que o leite atrapalhava ele. Então, essa foi também uma das coisas horríveis, porque enquanto você tem o leite, você está ligada com o seu filho, né? Me deram uma injeção à força, eu não quis tomar, briguei e tal, empurrei, aquela coisa. [...] Ele me pegou à força e deu injeção aqui na frente, na frente da coxa. [...] Depois que ele me falou: "Cortar esse leitinho aí, tirar esse leitinho". Realmente, acabou o leite. ${ }^{391}$

A situação dos presos que tinham filhos pequenos era igualmente utilizada para potencializar os resultados das torturas e ameaças, estendendo as sequelas também para as crianças. A ameaça aos filhos era constantemente usada como meio de coagir os presos e presas. Em muitos casos eles chegaram a ser efetivamente levados às dependências policiais. $E$ há relatos em que agentes do DEOPS/SP chegaram a praticar violências diretas contra crianças:

O meu filho mais velho, Carlos Alexandre Azevedo, suicidou-se na madrugada de hoje, com uma overdose de medicamentos. Com apenas um ano e oito meses de vida, ele foi preso e torturado, em 14 de janeiro de 1974, no DEOPS paulista, pela "equipe" do delegado Sérgio Fleury, onde se encontrava preso com sua mãe. $\mathrm{Na}$ mesma data, eu já estava preso no mesmo local. Cacá, como carinhosamente o chamávamos, foi levado depois a São Bernardo do Campo, onde, em plena madrugada, os policiais derrubaram a porta e o jogaram no chão, tendo machucado a cabeça. Nunca mais se recuperou. Como acontece com os crimes da ditadura de

\footnotetext{
${ }^{390}$ Relatório CNV p. 404-405, vol.1.

${ }^{391}$ Relatório CNV p. 408, vol.1.
} 
1964-1985, o crime ficou impune. O suicídio é o limite de sua angústia. ${ }^{392}$

Muitas crianças acompanharam seus pais na rotina de voltar ao DEOPS/SP, no período de liberdade vigiada. Em outros casos, os agentes do Departamento levavam os pais ao DEOPS enquanto outros ficavam na casa da família com as crianças sob a mira de fuzis. Para Rose, ainda que seu filho não tenha sido levado para as dependências do DEOPS, nem tenha ficado sob a mira de seus agentes, por meio desses afastamentos forçados entre pais e filhos, em virtudes das prisões, a ditadura "acabou com o melhor "que se tinha no Brasil, em atenção às marcas deixadas nos filhos de militantes políticos, um capítulo à parte em todas as experiências dessa época.

Das reconstituições daqueles tempos, surgem fartas referências aos caminhos percorridos pelos quatro narradores e, em consequência, por milhares de presos políticos. Era um trajeto que percorria os diversos órgãos da repressão na cidade de São Paulo. Neste ponto, suas falas auxiliam na compreensão do funcionamento da integração entre os vários órgãos da repressão: DEOPS, Operação Bandeirantes, DOI-CODI, Auditoria Militar e Presídio Tiradentes. De modo mais excepcional, também integravam aquela engrenagem, a Penitenciária do Estado, na cidade de Presidente Venceslau, a aproximadamente 600 quilômetros da capital paulista, e a Casa Custódia e Tratamento de Taubaté. ${ }^{393}$

As lembranças de Ivan, sobre os caminhos percorridos nas mãos dos agentes da repressão, são bem detalhadas. Perguntado sobre qual período teria estado no DEOPS, o narrador recorda todo o trajeto pelos diversos espaços por onde passou:

Inicialmente de maio até novembro de 1971. Depois me levavam para lá a cada dois meses, em média, e me mantinham preso lá por um período de outros dois meses. Isso aconteceu de durante os anos de 1971, 1972 e 1973, mês de outubro, quando fui isolado na Casa de Custódia e Tratamento de Taubaté, misto de penitenciária e manicômio, durante dois anos e oito meses seguidos. No total, se forem somadas todas as vezes que fui levado para lá, devo ter

\footnotetext{
${ }^{392}$ Relatório CNV p. 423.

${ }^{393}$ Também serviram aos órgãos de repressão no Estado de São Paulo, os chamados centros clandestinos de detenção. Os quatro narradores, embora também tenham vivenciado experiências de prisões clandestinas, não passaram por esses locais.
} 
ficado cerca de um ano e meio no cárcere do DOPS. ${ }^{394}$

As diversas situações às quais fora submetido nesse caminho, no entanto, também não surgem de suas falas. As busquei igualmente em outras fontes considerando serem bem peculiares e relevantes no sentido de conhecer melhor sua história e, ainda, considerando que são informações apresentadas por ele próprio em outro momento de sua vida. A vivência de Ivan naquele tempo aponta um vasto leque de subterfúgios utilizados pelo Estado para manter uma prisão clandestina, legitimá-la e legalizá-la quando conveniente: teve acesso à notícia jornalística da morte de seu pai enquanto ele ainda estava vivo; foi tido como desaparecido por cerca de oito meses, enquanto já estava preso, período em que foi mantido incomunicável; fizeram uso da Lei de Menores para mantê-lo preso; foi proferido laudo neurológico afirmando sua periculosidade "devido às más companhias"; tropas da Polícia Militar, Polícia Civil, Polícia federal e Operação Bandeirantes cercaram a Casa de Custódia no dia de sua soltura, conseguindo a revogação de sua liberdade; gozou de uma espécie de prisão perpétua não oficializada; conviveu com presos de alta periculosidade; e ficou sem acesso a jornais, cartas, revistas ou livros durante todo o período de prisão. ${ }^{395}$

Outras peculiaridades se fizeram presentes também nas experiências dos demais narradores, a partir de suas prisões. Elza e Rose, por exemplo, conheceram a Torre das Donzelas, como foi nominada a ala feminina do Presídio Tiradentes; Maurice ficou isolado em solitária no interior do Estado, local onde fez greve de fome, até que acabasse expulso do país, na condição de apátrida.

Sem dúvida as reconstituições dos ex-presos políticos sobre as experiências de vida nesses espaços possibilitaram, nos últimos anos, o início de uma compreensão da utilização dos mecanismos de Estado para a prática sistemática e bem afinada de violações de direitos humanos e hoje já é possível desenhar com bastante acerto o que foi todo aquele aparato de apoio e suporte ao governo de exceção. Sabe-se, por exemplo, que foi composto por diversos órgãos, recebia apoio de empresas particulares, e dividia-se em duas frentes, sob o conhecimento

\footnotetext{
${ }^{394}$ Questionário eletrônico respondido em 02/06/2015.

${ }^{395}$ BRASIL. Livro do votos da Comissão de Anistia: verdade e reparação aos perseguidos políticos do Brasil. Brasília: Ministério da Justiça; Florianópolis: Instituto Primeiro Plano. 2013. p. 269-270.
} 
e comando das Forças Armadas: uma voltada a atividades de inteligência, na obtenção e produção de informação e outra direcionada à efetiva repressão por meio da força. ${ }^{396}$

Ainda que houvesse reconhecida dificuldade de coordenação formal dos trabalhos e definição de funções, a rotina dos diversos órgãos de segurança em todo o Brasil contava com intenso intercâmbio de informações e presos. Dos arquivos da burocracia às salas de tortura; do almoxarifado, às celas coletivas e solitárias; dos camburões às salas de audiência; dos quartéis aos centros clandestinos de detenção, o trabalho de repressão seguia de modo bem orquestrado.

Essa rede de diferentes atores foi tida como um verdadeiro sucesso na repressão e combate à oposição política e contava com uma engrenagem bem complexa:

Além dos interrogadores, havia toda uma rede de atores subsidiários: investigadores de campo, tanto civis como militares, analistas de informações, torturadores, observadores dos pontos e dos aparelhos, comandos hierarquizados. Havia também estruturas de apoio, em serviços diversos, alguns com missões específicas, em clara divisão de trabalho entre aqueles encarregados de extorquir informações nos interrogatórios, outros de transcrever e datilografar depoimentos, outros de revesti-los de legalidade através de fórmulas acordadas entre os órgãos superiores, civis e militares." 397

Esse intercâmbio se dava para o DEOPS/SP, principalmente, com a Operação Bandeirantes, posteriormente, com os agentes do DOI-CODI/SP, com a Auditoria Militar, o Presídio Tiradentes e centros clandestinos, como descreve Maurice:

Fui preso aqui no DOPS no ano de 1970. [...] No início, a polícia não me conhecia. Mas aos poucos, outras pessoas foram sendo presas, outros documentos falsos meus apareceram e aí viram que eu estava bastante implicado. Por isso eu fiquei quase um mês na OBan e depois eu fui transferido para aqui. [...] Daqui, segui para o Tiradentes e aí fui condenado em uma primeira instância. [...] Então foi essa minha trajetória, mais ou menos. Passei quatro anos na prisão, em vários presídios. Aqui no DOPS, no Tiradentes, ficamos

\footnotetext{
${ }^{396}$ Mais informações no Relatório final da Comissão Nacional da Verdade.

${ }^{397}$ Sergio Adorno, Apresentação, No Centro da Engrenagem: os interrogatórios na Operação Bandeirante e no DOl de São Paulo (1969-1975), Mariana Joffily, Rio de Janeiro: Arquivo Nacional, São Paulo: EDUSP, 2013, p.17.
} 
isolados na Penitenciária. ${ }^{398}$

A sistemática é recordada por Ivan, de todos os narradores, o que mais tempo ficou no DEOPS, segundo suas próprias contas:

A primeira vez que eu vim para cá eu passei seis, sete meses aqui
escondido. Me mantiveram aqui. Me levaram para o Presídio
Tiradentes e dois meses depois me esconderam na Penitenciária
do Estado. Em Tiradentes eu tinha aparecido formalmente como
preso, tinha acabado de ser preso, como se fosse. Me esconderam
na Penitenciária, porque eles queriam me forçar a ir na televisão
dar aquelas declarações. Depois eu volto para o Presídio
Tiradentes. Alguns meses depois tem a greve de fome, eu volto
para OBan, Doi-Codi e depois fico lá quase um mês e volto para o
Presídio. Eu fico dois meses lá, dois meses cá, dois meses lá, dois
meses cá. Então, se fizer uma conta, assim, mais ou menos,
somando todos os meses que eu vim aqui e as várias vezes,
somando, dá quase um ano e meio que eu estive aqui. ${ }^{399}$

A rotina de transferências sistemáticas surge nas lembranças de Elza com alguma confusão espacial, de modo a deixar dúvida, por vezes, sobre o local a que se refere, não restando muito claro se tratar de uma lembrança do DEOPS ou de algum dos outros locais onde esteve presa. Mas se recorda bem de uma rotina de rotatividade:

O roteiro era assim: você chegava lá no DOI-CODI, do DOI-CODI você vinha para cá, para esse prédio, onde era o DOPS e daqui você ia para o Presídio Tiradentes, que não existe mais, que foi destruído. [...] Uma das coisas que acontecia é que primeiro começava no DOI-CODI, de lá você vinha para cá, ficava aqui onde são as celas [...].Daqui você ia para o Presídio Tiradentes e depois você ia para a Auditoria Militar para depoimentos."

Neste ponto é importante observar que a "confusão" da narradora, assim como o próprio silêncio, igualmente não invalida sua narrativa, como defende Bosi, diferentemente do que ocorre com a mentira, que pode ser "muitas vezes exata e detalhista." ${ }^{401}$

Continuando o desenho do papel do Departamento de Ordem Política e Social de São Paulo (DOPS/SP ou DEOPS/SP), na repressão política, este é bem

\footnotetext{
${ }^{398}$ Entrevista concedida em 10 jan. 2015.

${ }^{399}$ Entrevista concedida em 08 nov. 2014.

${ }^{400}$ Entrevista concedida em 08 nov. 2014.

${ }^{401} \mathrm{BOSI}, 2003$, p. 66
} 
peculiar. O órgão já existia quando da eclosão do golpe de 1964 e sua atuação na repressão política desse período foi de grande destaque: "de todos os Departamentos de Ordem Política e Social do país, nenhum foi mais atuante que o DOPS de São Paulo (DOPS/SP)", concluiu o Relatório Final da Comissão Nacional da Verdade, em dezembro de 2014. ${ }^{402}$

No momento em que é dado o golpe de 1964, o DEOPS/SP, ainda denominado DOPS, Delegacia de Ordem Política e Social, já contava com vasta experiência na repressão social e política, filosofia que incorporou na década de 1910, quando a atuação de grupos de anarquistas, comunistas e sindicalistas passa a ser "caso de polícia". A mais antiga polícia política do país contava, à época, com a simpatia das elites e do empresariado, tendo sob sua alçada, por exemplo, a tarefa de manter atualizado o registro de operários em lista de "indesejáveis". 403

Atuou sob esta cartilha já durante o Estado Novo, tendo em sua mira, por exemplo, a dissidência política e espiões alemães. Na década de 1950, além de comandar o presídio político e as agências de serviço secreto e de vigilância, era responsável por uma extensa lista de atividades de segurança:

[...] dirigir os serviços policiais ligados à investigação, à prevenção e à repressão dos delitos de caráter político, social e econômico; fiscalizar importação, exportação, comércio, fabricação, emprego ou uso de armas, explosivos, inflamáveis, munições, produtos químicos agressivos ou corrosivos; fiscalizar a entrada, a permanência e a saída de estrangeiros do território nacional, a partir do estado de São Paulo. ${ }^{404}$

Em 1964, o Departamento continuava com o apoio da elite econômica do país e possuía um corpo técnico qualificado e capacitado para o monitoramento e repressão à dissidência política, no qual passam a ganhar destaque, a partir de então, agentes com experiência em interrogatórios e torturas, além de contar com muitos informantes infiltrados entre os militantes.

Além de possuir o maior e mais bem organizado arquivo do país, o DEOPS/SP mantinha relações diretas não só com o Governo do Estado, a quem

\footnotetext{
402 Relatório CNV, p. 161, vol. 4.

${ }^{403}$ Relatório CNV p. 161 , vol. 1.

${ }^{404}$ Relatório CNV p. 162 , vol. 1
} 
se subordinava formalmente, mas também com o Conselho de Segurança Nacional da Presidência da República e com as Forças Armadas. ${ }^{405}$ Todo esse currículo faria do DEOPS/SP o departamento de polícia política e social, dentre todos do país, o que mais se destacaria durante o governo de exceção na tarefa de reprimir as insurgências contra o regime. Foi o DEOPS/SP, por exemplo, que colaborou com a instalação da Polícia Federal em São Paulo, inclusive pedindo doações a empresários. $^{406}$

Composto por agentes da polícia civil, entre delegados, investigadores e informantes, o DEOPS/SP ocupava todos os seis andares do prédio da Rua General Osório:

No subsolo, havia o almoxarifado e a carceragem com capacidade para cerca de 30 presos. Somente a delegacia de Sérgio Paranhos Fleury possuía uma carceragem própria; as demais utilizavam essa carceragem do subsolo [...] No térreo, além da recepção, funcionavam as salas de investigadores e guarda militar, com cerca de 200 policiais, empregados nas diligências do DOPS/SP; [...]no térreo e no primeiro andar ficavam investigadores que não pertenciam a nenhuma equipe específica, ou que estavam de plantão. O acesso ao pavimento térreo era livre, dado ali funcionarem várias delegacias. No entanto, aos andares superiores só se podia ter acesso com autorização de um delegado. [...]No primeiro andar funcionava a chefia-geral dos investigadores, salas para servidores, seção de pessoal, arquivo geral e restaurante para os servidores.[...] O segundo andar era utilizado pelo delegado Sérgio Fleury. Lá trabalhavam ele, três delegados assistentes, cerca de 40 investigadores e respectiva equipe de carceragem. Só seus protegidos podiam circular nesse andar. [...]No terceiro andar funcionava a Delegacia de Ordem Econômica e a Delegacia de Estrangeiros [...]ali também funcionavam ambulatórios de médicos e dentistas. [...] No quarto andar funcionavam a Diretoria-Geral e as Delegacias de Ordem Social e de Ordem Política [...] Na entrada da sala do diretor-geral havia uma luz vermelha que, se acesa, impedia o acesso à sala. [...]Era também nesse andar que ficava o Cartório Central. [...] Finalmente, no quinto andar funcionava o Serviço Secreto e, em uma área separada, sua Divisão de Informações, Contrainformação e Desinformação ${ }^{407}$.

Ao longo de sua trajetória na repressão política, pós golpe de 1964, agentes do DEOPS/SP fizeram parte das principais e mais sangrentas chacinas na

\footnotetext{
${ }^{405}$ Relatório CNV volume 1

${ }^{406}$ Depoimento do delegado José Paulo Bonchristiano, que atuava no DEOPS/SP, à CNV. Relatório CNV, p. 113, vol.1.

${ }^{407}$ Relatório CNV p. 167-168, vol.1.
} 
eliminação das organizações de resistência como, por exemplo: a emboscada que culminou com o assassinato do líder da Ação Libertadora Nacional, Carlos Marighella (1969); Operação Pajussara, mobilizada no interior da Bahia para localizar e eliminar Carlos Lamarca e que culminou na sua execução com mais quatro lideranças do MR-8 ${ }^{408}$; Operação Radar (1973-1976), para a dizimação de lideranças do Partido Comunista Brasileiro $(\mathrm{PCB})^{409}$; e a Chacina da Lapa, operação no bairro de mesmo nome na capital paulista que levou ao assassinato de dirigentes do Comitê Central do Partido Comunista do Brasil (PCdoB), (1976) $)^{410}$.

Nesta atuação, mantinha papel central em algumas atividades de controle, repressão e combate aos grupos de resistência política, como a gerência do Instituto Médico Legal, crucial para "validar tecnicamente os casos duvidosos", em relação a mortes de presos políticos ${ }^{411}$, desempenhando também o papel de local da burocracia:

b) o cartório: era necessário manter uma burocracia policial que produzisse a formalização das prisões e os laudos periciais; tornouse hábito, a partir daí, que os presos passassem a prestar depoimentos formais no DOPS/SP, mesmo já depois de terem sido interrogados e torturados pelos militares do DOI-CODI [... $]^{412}$

Chegar nesse momento de formalidade e legalidade de sua prisão era um momento de alívio. A partir dali seria possível ser localizado pela família e pelos advogados, dificultando a prática de torturas, o assassinato e as desaparições, como sente o narrador Maurice, ao falar de sua chegada ao DEOPS:

[...] aqui pelo menos a gente era legalizado. [...] Eles chamavam "fazer cartório", que era fazer o processo. As famílias já sabiam que você estava oficialmente preso. Na OBan a gente estava clandestino. A minha família cansou de ir na OBan e falavam: "Não, não está." Só quando estive aqui é que a família soube e então me mandou um bilhete e eu pude responder. Até minha mãe veio uma vez. Eles deixaram ela vir. e começou a me ver. ${ }^{413}$

\footnotetext{
${ }^{408}$ Além de Carlos Lamarca, na Operação que contou com o delegado Sérgio Fleury, foram assassinados Zequinha Barreto, Otoniel Barreto, Luiz Antônio Santa Bárbara e, em Salvador, lara lavelberg e a jovem Nilda Carvalho Cunha. Relatório CNV, p. 622 -628, vol.1.

${ }^{409}$ Relatório CNV p. 640 volume 1.

${ }^{410}$ Relatório CNV p. 648 volume 1.

${ }^{411}$ Relatório CNV p. 165 capítulo 4.

${ }^{412}$ Idem.

${ }^{413}$ Entrevista concedida em 10 jan. 2015.
} 
Mas foi também por meio deste aparato da burocracia que a repressão descobriu um jeito de expulsar Maurice do país:

Eu dou azar porque quando eu estava aqui, aqui era a burocracia. Nesse prédio trabalhavam duas mil pessoas. Tem que pensar que esse prédio inteirinho, seis andares, enorme, tinha gente para tudo. Em um dos dias que estava aqui, porque naquele tempo também não tinha telefone, o estrangeiro que queria virar brasileiro tinha que ir no departamento, jurar a bandeira e pedir o RG. E se você não fosse? Então eles te convocavam através do jornal. "Convocamos o indivíduo estrangeiro, damos dez dias, se não caduca o pedido e tal." E aí alguém viu meu nome. E vieram dizer: "Olha, você não é brasileiro." Eu disse: "Não, eu sou." "Não, você não é. Está aqui, tem que fazer a opção." Nem brasileiro, nem nada, apátrida. E foi por isso que depois que eu cumpri os quatro anos eles falaram: "não pode ser solto, tem que ser expulso do país, porque a Lei de Segurança Nacional diz que estrangeiro..." $E$ aí acabei saindo do país e morei muitos anos no exterior.

Nas interações entre os diversos órgãos, cada narrador parece ter destacado em suas recordações um ou outro mais fortemente. O narrador Maurice, por exemplo, é quem mais fala da Operação Bandeirantes - Oban, surgida no ano de 1969, quando o DEOPS/SP teve assento na sua Coordenação. Fruto de um agrupamento financiado por empresas privadas para a atuação coordenada entre os órgãos de segurança estaduais e federais na verdadeira caça aos grupos de resistência política, a OBan elevou o aparato repressor da ditadura a níveis excepcionais de violações, a partir da cidade de São Paulo.

Com a missão de "identificar, localizar e capturar os elementos integrantes dos grupos subversivos que atuam na área do II Exército, particularmente em São Paulo", a Oban tinha como objetivo maior dar fim ou neutralizar as organizações de oposição. ${ }^{414}$ Esta união de forças de segurança e financiamento do empresariado trouxe, ainda, as Forças Armadas para as linhas de frente da atuação policial:

[...] reunia elementos provenientes das três forças amadas (Exército, Marinha e Aeronáutica), do DOPS, do SNI, do DPF e da Secretaria de Segurança Pública (Polícia Civil, Força Pública, Guarda Civil). (...) O novo órgão não foi legalmente oficializado. Seu comando coube ao Exército - nas pessoas do coronel Antônio Lepiane, chefe do Estado- Maior da segunda divisão de infantaria -, que fez dele o meio de entrada, em grande escala, das forças armadas em operações de ordem policial, especializadas na

\footnotetext{
${ }^{414}$ Relatório CNV p. 127-129 vol.1.
} 
repressão política ${ }^{415}$.

Neste agrupamento de forças, o DEOPS/SP mantinha seus agentes à disposição de um dos braços da Oban, responsável por inúmeras "prisões ilegais, interrogatórios, torturas, execuções e desaparecimento forçado de militantes". A Operação recorria a intensas práticas de torturas, "como se, para seus agentes, a tortura fosse o meio para alcançar o sucesso das operações, como se os fins justificassem todos os meios, para além de qualquer dimensão ética."416

É da passagem pela Operação que surgem para Maurice as lembranças de uma rotina marcada por investidas mais violentas: "a lembrança que eu tenho do DOPS, entre uma e outra sessão mais violenta, eu não fui torturado aqui. Eu fui torturado na OBan." Lembra, ainda, que "na OBan, era um por dia. Você ficava sozinho, você não tinha com quem compartilhar, na época que eu fiquei."

Somente após o êxito na obtenção das informações, é que os agentes da Oban encaminhavam o preso para as dependências do DEOPS, a fim de registrar e "legalizar" sua prisão. Depois de quase um mês na OBan, é que Maurice Politi, por exemplo, foi identificado como preso e transferido para O DEOPS/SP.

Como mais um exemplo dessa atuação conjunta, a ALN, organização na qual atuaram os narradores Maurice e Rose, foi um dos maiores alvos dessa parceria. Foi em uma das tentativas de desmantelar a ALN que Maurice foi parar no DEOPS e posteriormente na OBan, em virtude de sua atuação no apoio logístico à organização. A intenção de eliminar as organizações de oposição estava mesmo no objetivo central desta parceria, tanto que as mortes por tortura e execução de membros da $A L N$, só para citar uma única organização, corresponderam a $14 \%$ do quadro total deste método utilizado pela repressão política. ${ }^{417} \mathrm{Ou}$, seja, a cada 100 militantes mortos sob tortura, 14 pertenciam à organização de Rose e Maurice.

Em um determinado momento, os níveis de violações de direitos humanos e práticas de crimes pelos agentes de Estado atingiram graus dos mais elevados.

\footnotetext{
${ }^{415}$ JOFFILY, Mariana, No Centro da Engrenagem: os interrogatórios na Operação Bandeirante e no DOI de São Paulo (1969-1975), Rio de Janeiro: Arquivo Nacional, São Paulo: EDUSP, 2013, p.43.

${ }^{416}$ Relatório CNV p. 136 , vol. 1.

417 Relatório CNV p. 443, vol.1.
} 
Era a resposta às investidas das organizações de resistência. A época em que o DEOPS aparece mais implicado em sistemáticos casos de graves de violações de direitos humanos foi aquela sob o comando do delegado Sérgio Paranhos Fleury, o que prendeu pessoalmente a narradora Rose, em sua casa, quando estava com seu bebê de um mês de vida nas mãos.

Foi também no DEOPS, comandado por Fleury, que a narradora sofreu torturas físicas e psicológicas. Quando este agente assume o Departamento em 1968, o órgão ganha notoriedade na contenção da resistência política. Conhecido por suas estratégias sádicas na tortura de presos, mantinha presos "exclusivos" sobre os quais somente pessoal de sua extrema confiança teria conhecimento. A ele é ainda atribuída a manutenção e utilização de centros clandestinos de detenção, como um no bairro de São Conrado, na cidade do Rio de Janeiro, conhecido como "Casa de São Conrado" e outro em São Paulo, conhecido como "Fazenda 31 de Março". 418

Sob seu comando, o DEOPS/SP passou a sua fase de maior recrudecimento da repressão:

\footnotetext{
Uma pergunta que vocês estão cansados de fazer: "Tinha tortura [no DOICODI do II Exército]?". Eu digo que, institucionalmente, não. Mas, eu imagino que possa ter havido. Eu seria inocente e ia bancar o idiota na frente de vocês se dissesse que não. $E$ quem nos ensinou a trabalhar foi a Polícia Militar e a Polícia Civil. A Polícia Civil era [o pessoal] do DOPS, comandados pelo Sérgio Fleury, o maior delegado que São Paulo já teve. E, lá, era na base do "pau". ${ }^{419}$
}

Era a repressão política comandada por quem "matava criminosos comuns, numa tentativa de limpar a sociedade" 420 . E, ainda, segundo a narradora Rose Nogueira, "a polícia civil e o esquadrão da morte que comandavam o país na época." 421

Essas lembranças das dores e violências sofridas naqueles tempos são interrompidas em suas falas pelo desejo de contar outras experiências. De um modo que ouso dizer surpreendente, os quatro narradores atravessam os

\footnotetext{
${ }^{418}$ Relatório CNV p. 804.

${ }^{419}$ Relatório CNV, p. 112 vol.1.

${ }^{420}$ Relatório CNV, p.166, vol.1.

${ }^{421}$ Entrevista concedida em 07 nov. 2014.
} 
momentos de trauma para chegar às lembranças de alento. São recomposições que evocam os sentidos de solidariedade, companheirismo e afeto compartilhados pelos ex-presos políticos naqueles tempos vividos atrás das graves, onde parecia imperar a "preocupação não consigo mesmo, mas com o próximo", e que tomam suas recordações de modo bem contundente e constante durante as entrevistas. ${ }^{422}$

O tempo de permanência no DEOPS surge, assim, como um tempo de descanso, se comparado a outros locais da repressão por onde passou naquela mesma época, segundo as recordações de Maurice Politi. Entre os "alívios" recordados pelo narrador estão, além da oficialização de sua prisão, também o fim da solidão. Era ali que ficavam em celas coletivas e onde era possível vivenciar os cuidados mútuos entre os presos que voltavam feridos após as sessões de tortura.

Esse cuidado com o companheiro seviciado nas ininterruptas e subsequentes sessões de tortura surgem também nas recordações do narrador Ivan, igualmente com o mesmo sentido de acalanto:

[...] quando alguém chegava torturado a gente estava junto, a gente puxava para o colchão, a gente dava comida, levava no banheiro e tal, porque estava quebrado. Estes momentos, para ele, em há o cuidado, a solidariedade, superam os sentidos da tragédia: "no momento em que você tem uma relação de amigos e companheiros, em que você pega e estende a mão, que você acarinha, que você carrega, é muito maior que a tortura. ${ }^{423}$

Havia no cárcere, ainda, uma necessidade de os presos se envolverem, de se preocuparem e colaborarem uns com os outros, e de "não ficar fechada em você", como coloca a narradora Elza:

[...] a gente foi abrindo um caminho de sempre pensar nos outros. Não era uma coisa de ficar fechada em você. Você tinha que ver o que estava acontecendo, quem estava com mais dificuldades, quais as pessoas que estavam com muita limitação e tudo isso fazendo com que a equipe fosse cada vez mais se unindo. ${ }^{424}$

A narradora recorda que "naquele momento você tinha um envolvimento em que se tentava, a cada pessoa nova pessoa que chegava, saber quem era, de onde veio, o que aconteceu, como é que a pessoa se situava dentro do contexto

\footnotetext{
422 Entrevista concedida em 08 nov. 2014

${ }^{423}$ Entrevista concedida em 08 nov. 2014.

${ }^{424}$ Entrevista concedida em 08 nov. 2014.
} 
todo." O clima entre os presos, emerge nas lembranças de Elza Lobo como sendo de colaboração mútua, seja nas recordações dos tempos de DEOPS ou do Presídio Tiradentes:

Foi muito marcante, foram dois anos de prisão. Nos dois anos teve muita atuação de apoio entre as várias presenças as mais diversas [...] nessa caminhada você tinha também que ter um envolvimento com as pessoas [...] tentar fazer com que as pessoas soubessem o que estava acontecendo e, por outro lado, elevar a moral das pessoas, para que as pessoas não se sentissem sem nenhum contato, sem nenhum tipo de apoio, porque era uma situação muito pesada. [...] Foi um momento muito intenso de tentar ver o que era possível de ser feito, como é que você podia estar conversando com as pessoas e isso foi uma postura que não foi só minha, foi de todas nós. ${ }^{425}$

É daquele presídio que a narradora restaura nas suas lembranças as atividades conjuntas realizadas com o intuito não só de ocupar a mente das presas, mas também render de fato uma produção que pudesse ser revertida no auxílio da própria resistência política. Havia na vida do cárcere, então, uma preocupação também com que ocorria lá fora, na resistência que continuava nas ruas, na clandestinidade. Quem estava preso, continuava a resistir agora de outras formas:

E tentar que se tivesse produção. Então se fazia trabalhos manuais. Conseguimos ter na Rua Augusta, que é uma rua bem badalada de São Paulo, a gente conseguiu abrir uma loja, através de amigos que estavam fora, e colocar os produtos que se fazia para venda na Rua Augusta, que era a rua mais badalada. Tinha uma menina que já faleceu que fazia crochê muito bem. Fez um véu de noiva todinho de crochê e esse véu foi vendido para uma socialite do Rio de Janeiro que nem sabia que aquilo saiu do presídio, que ela comprou na loja da Rua Augusta. E foi uma renda boa que ajudou familiares que estavam com dificuldade. ${ }^{426}$

A força das atividades coletivas e responsabilidades compartilhadas segue na voz de Elza, para quem o trabalho coletivo parece ter uma força muito forte, sendo citada em vários momentos de sua vida, antes mesmo da prisão e, depois dela, também no exílio:

A gente conseguiu que esse espaço não ficasse trancafiado. Você ficava com essa parte que se foi arrumando. Vinha um latão com uma comida horrorosa, que ninguém comia. A gente começou a ter uma espiriteira e duplas de cozinha. Você ia fazendo com que as

\footnotetext{
${ }^{425}$ Entrevista concedida em 08 nov. 2014.

${ }^{426}$ Entrevista concedida em 08 nov. 2014.
} 
pessoas se organizassem. No dia tal é fulano, no outro dia outra. Ter uma forma de apoio a todas e ao mesmo tempo era importante que todas tivessem sua responsabilidade. Esse foi um marco que caminhou muito. ${ }^{427}$

As preocupações e cuidados coletivos se estendiam também às rotinas de interrogatórios, quando afloravam questões como saúde, higiene e autoestima. Nas ocasiões em que os presos seriam conduzidos para interrogatório no prédio da Auditoria Militar, por exemplo, ocasião em que eram expostos pelos órgãos repressão à imprensa e à sociedade, sendo apresentados como terroristas, "o que se fazia era se preparar para ir bem vestida, bem arrumadinha e levantar a cabeça, não deixar ninguém ficar abalado porque sabia que ia acontecer esse tipo de situação", recorda Elza. ${ }^{428}$

As recordações afetivas da vida no cárcere parece seguirem com os narradores nas suas trajetórias de vida. A experiência de Ivan, por exemplo, trouxeIhe um grande presente afetivo que carrega até os dias hoje. Ao tempo de prisão em que perdeu seu pai, foi também da experiência do cárcere que conheceu Raphael Martinelli, seu eterno "véio", com quem desenvolveu uma relação de amizade para a vida toda:

[...] eu fui parar na cela dele quando fui preso no Tiradentes, eu sou um aprendiz dele desde lá de dentro. Meu pai morreu com 49 anos, ele tinha 49 anos quando eu cheguei lá. Até hoje eu chamo ele de véio e ele me chama de moleque, mesmo eu com 60 anos idade, sou o moleque (risadas). ${ }^{429}$

Muitas imagens do modo como o grupo de narradores percebe essas experiências de solidariedade no cárcere, estão presentes na concepção do Memorial da Resistência, como observa o narrador Ivan, voltando à história da flor permanentemente instalada no centro de uma das celas reconstituídas no Memorial da Resistência, que representa o presente compartilhado da narradora Elza com demais presos. E, sobre as lembranças do companheirismo e do afeto no cárcere, para àqueles que se viam presos, torturados, sozinhos e abandonados,

\footnotetext{
${ }^{427}$ Entrevista concedida em 08 nov. 2014.

428 Entrevista concedida em 08 nov. 2014.

${ }^{429}$ Entrevista concedida em 08 nov. 2014.
} 
conclui: "obviamente que é uma coisa que acaricia o coração da pessoa."

\section{3 "SOU MILITANTE DOS DIREITOS HUMANOS DESDE O DIA QUE SAÍ DA CADEIA"431: A VIDA DEPOIS, AGORA E ADIANTE.}

A pauta da resistência política que se levantou frente ao regime de exceção, no sentido de retomar os caminhos da democracia, veio sempre acompanhada das lutas sociais. Ao sair em defesa dos direitos dos presos políticos, fazendo denúncias sobre as violências e arbitrariedades cometidas pelos agentes da repressão, a pauta dos movimentos de resistência, ia além. Evelina Dagnino chama atenção para o início do projeto democrático em construção no Brasil ainda nos idos da repressão, por meio da atuação da sociedade civil organizada, embora seu marco formal tenha sido a Constituição Federal de $1988 .{ }^{432}$

As discussões e bandeiras desses grupos tinham já naquele tempo um sentido sempre mais amplo de cidadania e democracia. Trabalhavam na perspectiva da emancipação social, da educação democratizada e democratizadora, e da participação social nas esferas decisórias do projeto político, como visto no capítulo primeiro.

Sem demonstrações de arrependimentos, parece ter sido com o sentimento de orgulho e dever cumprido, que os quatro narradores seguiram suas vidas após o fim da ditadura e a retomada da democracia, até o reencontro do grupo na década de 2000 em torno da retomada do Memorial.

O grupo de narradores seguiu com sua vida, cada um a seu modo. Maurice Politi viveu fora do Brasil, até retornar com esposa e filhos. Rose Nogueira, não teve outro filho, montou a "praça Che Guevara" nos fundos de casa e se cercou de flores, frutos e animais. Elza Lobo permaneceu solteira e tem orgulho de seus sobrinhos-netos. Ivan Seixas se casou, teve filhos, se separou.

Assim como as escolhas pela resistência política em face da ditadura se deram por escolhas bem individuais, mas com um desejo comum, também as escolhas que se seguiram à retomada da democracia, se assemelham em algumas

\footnotetext{
${ }^{430}$ Entrevista concedida em 08 nov. 2014.

${ }^{431}$ Fala de Rose Nogueira na entrevista concedida em 07 nov. 2014.

${ }^{432}$ DAGNINO, 2004, p.95.
} 
aspirações: a permanente luta pela garantia e defesa dos direitos humanos; o compromisso com a juventude atual e a vontade de reconstituir e manter vivas as experiências de resistência política da época da ditadura.

As quatro trajetórias, já em um Estado Democrático de Direito, fundado nos princípios da cidadania e da dignidade da pessoa humana, apontam para pelo menos uma conclusão: das ruas ao cárcere, da anistia ao Memorial da Resistência, o grupo tem mantido sua convicção de que é preciso resistir. Parece que todos trazem das experiências da resistência política contra a ditadura a ideia central da luta pelos direitos humanos, de que a "luta continua." Este é o tom que surge nas quatro narrativas quando falam dos trabalhos com a juventude, dos problemas sociais que ainda persistem, e da violência policial nas periferias, por exemplo.

Nas últimas décadas mantiveram seu compromisso com as causas sociais e a luta pela garantia dos direitos humanos. Essa tarefa, que parece terem abraçado como uma missão, dialoga com a concepção de direitos humanos enquanto um processo de luta constante na conquista de direitos que eleve a vida ao mais alto grau de dignidade.

É esta exatamente a noção que surge na fala de Rose:

Eu não consigo ver a história como um evento, ou vários eventos grudados uns nos outros, eu só vejo a história como um processo. E a história dos direitos humanos é um processo e um processo de luta, ainda. Porque nós não atingimos nem metade do que está na primeira carta, como humanidade. ${ }^{433}$

A evolução dos direitos humanos é vista pela narradora como um caminho em eterna construção:

O homem tem direito à vida, o homem tem direito ao teto. Então, se você for examinar a carta dos direitos humanos da Revolução Francesa você vai ver que ela é atual. A da Revolução Americana também, é um aperfeiçoamento daquela. A da ONU ainda é um aperfeiçoamento daquela. E o DHESCA, como a gente chama para resumir, da Convenção de Viena de noventa e três, é um aperfeiçoamento também. Eu sempre fiquei muito chocada, porque tudo que o mundo todo ainda não tem como direitos humanos estava lá na carta da Revolução Francesa do século XVIII. Tá tudo lá... ${ }^{334}$

\footnotetext{
${ }^{433}$ Entrevista concedida em 07 nov. 2014.

${ }^{434}$ Entrevista concedida em 07 nov. 2014.
} 
E por saber que a luta é permanente, a narradora é enfática no compromisso assumido: "É por isso que eu luto pelos direitos humanos e vou até o fim da minha vida, de uma maneira ou de outra, da maneira que eu puder."

A ligação de Elza com o serviço voluntário junto à comunidade, por exemplo, iniciado ainda durante a militância estudantil no trabalho de alfabetização de adultos, no desejo de erradicar o analfabetismo, estendeu-se também nos tempos de asilo político, pelos vários países por onde esteve - Argentina, Chile, Peru e França, atuando também junto às Nações Unidas, por meio da UNESCO. Em Paris, trabalhou na sede do Comitê Coordenador de Serviço Voluntário onde desenvolvia atividades de debates sobre as diferentes realidades dos diferentes países.

Ao retornar ao Brasil, no ano de 1979, a narradora continuou suas atividades na área da educação e também da saúde, junto às secretarias do Município e do Estado de São Paulo respectivamente, até sua aposentadoria em 2014, em uma "caminhada sempre de envolvimento com os grupos locais, sociais, de tentar trazer um pouco da caminhada do que se tinha vivenciado fora para ver o que a gente podia trabalhar internamente no país."

Maurice ficou no exílio desde sua expulsão até a aprovação da anistia, em 1979. Até aquele momento, morou com sua irmã mais nova em Israel: "Pela minha religião eles davam a cidadania na hora. Eu precisava de um passaporte, então eles me davam uma cidadania e dão até hoje. Qualquer judeu que pedir a cidadania eles dão na hora". ${ }^{435}$

Esta acolhida em Israel possibilitou também o seu reencontro com a irmã mais nova, enviada para lá pelo pai quando o narrador foi pego pelos órgãos de repressão para que não sofresse sua influência.

O trabalho em uma empresa multinacional levou Maurice a ficar fora do país de 1985 a 2004, quando passa a frequentar o Fórum de ex-presos de São Paulo, participando do processo de ampliação da pauta da entidade para a promoção da memória. Nesta época, sua preocupação com o tema o levou a trabalhar com implantação de políticas públicas de memória no cargo de Coordenador-Geral de Memória da Secretaria de Direitos Humanos da Presidência da República. A luta

\footnotetext{
${ }^{435}$ Entrevista concedida em 10 jan. 2015.
} 
de Maurice pela promoção da memória da resistência à repressão o tem levado nos últimos anos a buscar a formação de vários memoriais na cidade de São Paulo e a prestar assistência a vários grupos de ex-presos em outros locais. Expressa o desejo de ocupar todo o prédio do DEOPS para o Memorial. Quer ocupar o DOICODI, atuara no prédio da Auditoria Militar. Maurice quer traçar na cidade o mapa da memória da resistência, uma forma de salvar os jovens com seu "quinhão de areia."

No caminho seguido por Rose, mesmo antes do fim da ditadura, quando ainda permaneceria em liberdade vigiada por dois anos, a luta pelos direitos humanos foi uma decisão tomada no momento em que deixou a prisão:

Desde o dia que eu saí da prisão, nove meses depois de ter entrado, respondendo a processo por mais dois anos e meio de liberdade vigiada, desde o dia que eu saí da prisão eu decidi que eu lutaria pelos direitos humanos. E é o que eu faço até hoje e vou continuar fazendo onde eu estiver. ${ }^{436}$

Há quarenta anos nesse compromisso, a narradora passou a atuar no Grupo Tortura Nunca Mais de São Paulo (GTNM-SP), sendo sua atual diretora. Fundado ainda clandestinamente no ano de 1976, reunia familiares de mortos e desaparecidos e também de sobreviventes das torturas na tentativa de buscar informações sobre as circunstâncias em que se deram aqueles tantos crimes. Com o fim da ditadura, o grupo continuou seu trabalho em relação às violações do período de exceção, somando à sua agenda de lutas também a denúncia de torturas e outros crimes praticados por agentes de Estado já no Estado democrático. No ano de 1987 foi tido como entidade de utilidade pública.

Atuando na defesa e promoção dos direitos humanos, civis, econômicos, sociais, culturais e ambientais, a entidade trabalha em pautas sempre bem atuais: denúncias de torturas praticadas por policiais; produção de pesquisas e relatórios sobre violência policial, segurança pública e política de extermínio; execuções sumárias ocorridas na Baixada Santista no ano de 2006; reconstituição da memória histórica da resistência às ditaduras na América Latina; fim dos autos de resistência e do uso de armas de baixa letalidade. ${ }^{437}$

\footnotetext{
${ }^{436}$ Entrevista concedida em 07 nov. 2014.

${ }^{437}$ Disponível em: <http://www.torturanuncamais-sp.org>. Acesso em: 12 jul. 2015.
} 
$\mathrm{Na}$ condição de presidente do GTNM-SP, segundo as lembranças da narradora, "lá pelo ano de 2002", passou a atuar também no Conselho Estadual de Defesa da Pessoa Humana de São Paulo (CONDEPE) ${ }^{438}$. Ivan Seixas também foi presidente do Conselho, que nasceu ainda durante a ditadura já como iniciativa da sociedade civil na defesa e promoção dos direitos humanos e cujas primeiras ideias são atribuídas também ao professor Fábio Konder Comparato para ser "um conselho com total autonomia, e que é fundamental para a garantia dos direitos humanos no Estado e evidentemente com repercussão nacional." 439

$\mathrm{Na}$ esteira da nova democracia apresentada pela Constituição Federal de 1988, o Conselho "foi refletido envolvendo vários seguimentos da sociedade civil” $^{\prime 40}$, para converter-se em espaço capaz de expressar os anseios sociais na promoção de uma sociedade mais justa e igualitária, com respeito às garantias constitucionais e à dignidade humana, acima de projetos de governos.

A participação em conselho deliberativo, com poder de fiscalizar e impulsionar o Estado, segue na esteira dos expoentes da nova cidadania, surgida com a Constituição Federal.

O órgão de Estado do qual participam os narradores Rose e Ivan tem sua atuação reconhecida, em especial, contra a violência policial:

Quantas e quantas vezes os membros do CONDEPE estiveram presentes em prisões e em estabelecimentos de saúde mental do Estado. Realmente a atuação do CONDEPE, de seus conselheiros, de todos os tempos sempre foi realmente exemplar. Vale à pena ser CONDEPE, colaborar com o CONDEPE porque ele tem força, tem independência. Tem força natural que é aquela que vem do povo e o povo deu esta força ao CONDEPE. ${ }^{441}$

Rose, a partir do CONDEPE, recorda a evolução dos diversos conselhos protetivos do Estado de São Paulo:

\footnotetext{
${ }^{438}$ O CONDEPE foicriado pela Lei $n^{\circ} 7.576$, de 27/11/1991, da Assembleia Legislativa do Estado de São Paulo, com a finalidade de "com a finalidade de investigar as violações de direitos humanos no território do Estado, encaminhar às autoridades competentes as denúncias e representações que Ihe sejam dirigidas, estudar e propor soluções de ordem geral para os problemas referentes à defesa dos direitos fundamentais da pessoa humana."

${ }^{439}$ Vídeo "20 anos de Condepe-SP publicado no Canal de Condepe SP em 17 de janeiro de 2012.

${ }^{440}$ Idem.

${ }^{441}$ Depoimento de Antonio Carlos Malheiros, Desembargador do Tribunal de Justiça de São Paulo, no vídeo "20 anos de Condepe-SP (Conselho Estadual de Defesa dos Direitos da Pessoa Humana)", publicado no CanaldeCondepeSP, em 17 de janeiro de 2012. Disponível em https://www.youtube.com/watch?v=D_SUiFC4m5o.. Acesso em: 19/07/2015.
} 
É um Conselho de Estado, não é uma ONG como muita gente pensa, não tem nada a ver (risos). Seria dentro dessa proposta de participação popular o melhor que nós tivemos em São Paulo, instituído no governo do Franco Montoro, se não me engano. Não sei se foi no Franco Montoro, para falar a verdade. Mas nós já tivemos o Conselho de Defesa da Mulher, de Defesa da Criança e dos Direitos Humanos, que é o CONDEPE, que foi considerado uma grande conquista na época. Então, esses conselhos existem para que você possa atuar a favor dos direitos humanos, para que você possa verificar, dar parecer e até prender quem viola os direitos humanos, e ele está acima dos governos. Para um monte de gente é considerado só um trampolim político. E eu levei a sério, eu levo a sério tudo que eu faço. ${ }^{442}$

Quando fala de sua atuação na defesa dos direitos humanos, a convergência de uma complexidade de direitos necessários a uma vida digna e a necessidade de unir esforços para fazer desta pauta uma luta sempre atual, ganha sentido na fala da narradora:

Nos direitos humanos eu gosto muito de seguir os conceitos do DHESCA. O DHESCA refere-se aos conceitos dos direitos humanos, aperfeiçoando a carta dos direitos humanos da ONU de quarenta e oito, que são direitos econômicos, sociais, culturais e ambientais. Então eu não consigo ver o homem isolado, eu só consigo ver dentro desse contexto, desse mundo humano mesmo, que são as condições sociais, econômicas, culturais e ambientais. E eu continuo lutando pelos direitos humanos. ${ }^{443}$

Defensora também dos direitos dos animais, Rose acredita na irmandade dos povos e na herança da doçura da manga plantada pelos negros escravizados para alimentar seus filhos. Sua fala é repleta de referências que parecem justificar sua escolha por uma vida em defesa dos direitos humanos. Não raro faz referência ao respeito às diferenças, ao respeito "a tudo que é vivo" e à necessidade de harmonia entre os seres humanos e a natureza. Seja na praça "Che Guevara" construída no jardim de casa, entre suas flores, pássaros e cães, ou ao lado das muitas mães que ainda buscam justiça pelas mortes de seus filhos, nas periferias da cidade de São Paulo, a mulher que teve seu filho arrancado dos braços para suportar as dores das torturas, carrega, ao lado de suas dores inevitáveis, a crença na evolução do ser humano e em mundo melhor:

\footnotetext{
${ }^{442}$ Entrevista concedida em 07 nov. 2014.

${ }^{443}$ Entrevista concedida em 07 nov. 2014.
} 
[...] eu acho que é uma das coisas mais importantes que tem do pensamento humano, é o respeito ao outro, sua personalidade, porque nós somos tão iguais e tão diferentes, tão únicos. Tudo que é vivo é único, seja aquela folha ali do lírio, seja nós seres humanos, seja o cachorrinho, seja a tartaruga. Todos nós representamos uma evolução e é nessa evolução que eu estou interessada, em um mundo melhor. ${ }^{444}$

Ao final, mesmo que a juventude de outrora não tenha alcançado todo o seu conjunto de anseios, na eterna luta pela conquista e garantia de direitos, há também, como acredita Elza, a certeza de que a caminhada ainda não acabou e que muito ainda está por ser feito. E se, diante do preço cobrado aos que se levantam frente a um estado de coisas que não corresponde aos anseios de uma vida mais justa e igualitária, restar alguma dúvida, Rose Nogueira adianta: "toda luta vale à pena, viu?!"

\footnotetext{
${ }^{444}$ Entrevista concedida em 07 nov. 2014.
} 


\section{CONSIDERAÇÕES FINAIS}

Com o fim do último regime de exceção e violação de direitos, a partir da anistia de 1979 e mais profundamente com a promulgação da Constituição Federal de 1988, o Brasil deu passos significativos na recomposição de um Estado comprometido com os direitos humanos. Com a Carta Cidadã, deu-se uma explosão de normas jurídicas e atuações políticas de proteção e promoção de direitos e exercício da cidadania, ampliando-se os meios e mecanismos de participação social nas esferas decisórias do Estado.

Além disso, o Brasil é parte de comunidades internacionais de direitos humanos, como o sistema das Nações Unidas e da Organização dos Estados Americanos, obrigando-se a internalizar e sancionar seus paradigmas. A partir dessa integração, o Estado brasileiro assume compromissos com padrões elevados de defesa e promoção dos direitos humanos, incluindo-se o dever de assumir, enfrentar e sanar as consequências dos episódios de sistemáticas violações de direitos humanos praticados sob sua responsabilidade, como aqueles que foram prática corrente do governo de exceção.

Todo esse arranjo, contudo, não foi suficiente para impulsionar um processo radical de resposta às heranças deixadas pelas décadas da ditadura iniciada no país no ano de 1964. Ao longo das últimas décadas, justamente pelo seu não enfrentamento de modo primordial, muitas das violações praticadas durante a ditadura permanecem em diversas estruturas sociais, desde a criminalização da militância política até a própria estrutura do Estado que, ou nega as violações praticadas, ou se abstém de apurá-las, em especial, nos órgãos de segurança pública.

No entanto, é preciso reconhecer um lastro de ações significativas de alguns órgãos e grupos sociais: ampliação considerável dos registros de depoimentos de vítimas, levando-os por todas as regiões do país; a judicialização da responsabilização criminal; as demandas sociais no sistema interamericano de direitos humanos; e a criação de uma comissão nacional da verdade, e outras tantas espalhadas pelo país, ação que ampliou consubstancialmente as 
investigações sobre as circunstâncias em que se deram as violações naquele período. Nesse processo, o Memorial da Resistência desponta como valioso mecanismo na construção e promoção da memória, e de outros tantos aspectos que dela refletem.

Ecléa Bosi ensina que "o espaço é capaz de exprimir a condição do ser no mundo" 445 , indicando que, a partir de nossa relação com os locais que nos cercam, o modo como os ocupamos e os transformamos, pode nos manter como meros espectadores ou como sujeitos ativos do cotidiano da vida. E é com essa concepção transformadora de nosso "estar" no mundo que, levada pelo fio condutor das lembranças de ex-presos políticos engajados na construção da memória social da repressão e da resistência políticas, encontro uma participação social pulsante no Memorial da Resistência.

Mais que um conjunto de acervos de informações, essas vozes me mostraram um local que é hoje terreno fértil de debates e reflexões políticas, sociais e culturais, cujo trabalho ali realizado vem somar expressivos esforços na pauta do enfrentamento das violações de direitos humanos, de ontem e de hoje. Suas falas permitem o uso dos processos do passado como mecanismos de problematização de nossa realidade presente, de modo que se possa compreender uma história não mais "do alto de um prédio", mas descendo as escadas e se embrenhando no cotidiano, "observando o mundo a partir das lentes da cultura, tirando dos becos os sujeitos ordinários."

A partir das narrativas, percebi no Memorial um tributo não só à liberdade e à resistência. Ali as experiências de vida são colocadas a serviço da coletividade; lançam luz às experiências invisibilizadas e propõem processos de reflexão política, em verdadeiro engajamento cívico.

A cada vez que um jovem se interessa em passar uma tarde de sábado no Memorial para ouvir o que um ex-preso político tem a dizer; a cada vez que alguém entra em uma cela reconstituída e lê os escritos de presos no concreto; que lá vê o

\footnotetext{
${ }^{445}$ BOSI, 2003, 71.

${ }^{446}$ ARAGÃO, Milena;TIMM, Jordana Wruck;KREUTZ, Lúcio. A história oral e suas contribuições para o estudo das culturas escolares. Conjectura: Filos. Educ., Caxias do Sul, v. 18, n. 2, p. 28-41, maio/ago. 2013.
} 
colchão onde muitos dormiram e outros tantos agonizaram, está-se operando a empatia, a capacidade de compreender a vida, a dor e a luta do outro, e "de outros", de um grupo e de uma geração.

No uso daquelas histórias de vida para retomar, recompor e dar vida ao Memorial, pude captar nas suas falas percepções que foram além do processo de formação do espaço ao admitirem, por exemplo, que embora haja esforços do Estado brasileiro em ampliar uma agenda que proteja e promova os direitos humanos, ao mesmo tempo tudo isso se opera com lentidão, permitindo a perpetuação das violações de direitos humanos nos dias de hoje, como o uso da tortura e desaparição forçada como métodos de atuação dos órgãos policiais; a política de combate ao inimigo interno dos órgãos de segurança pública, manifesta na criminalização dos movimentos sociais; a apatia e o descompromisso com questões políticas e, ainda mais grave, as recentes manifestações públicas em deferência ao retorno da ditadura. Essa percepção, no entanto, não tira o ânimo do grupo. Daí sua certeza de que ainda há muito a ser feito.

A partir de suas falas, percebi, ainda, que compreendem essas questões como consequências do negacionismo e do obscurantismo do próprio Estado sobre as violências cometidas e sobre a própria resistência política que foi igualmente relegada da história oficial do Brasil por tantas décadas. Por isso, os narradores, enquanto representantes de uma parcela muito maior de resistentes, abraçam sua tarefa de contar suas experiências às novas gerações, enquanto compromisso com a memória social e com a própria cidadania. Não há, assim, nas reconstituições de suas lembranças, a nostalgia de quem revive o passado sem significados no presente e sem olhar para o futuro. Ao contrário, percebi no grupo a necessidade de "emprestar" suas histórias no emprego de significativas mudanças.

Compreendi a intenção dos narradores em fazer propagar na juventude atual o potencial da resistência, talvez também como forma de manter vivos seus próprios sonhos de juventude. Resta claro que sua luta não ficou lá atrás. Ao contrário, mantiveram-se firmes no compromisso com as causas sociais e na luta constante que constitui os próprios direitos humanos. O trabalho de construir uma memória social a partir das experiências vividas na ditadura se insere em suas vidas como mais uma tarefa dentre tantas outras, como um "caminho natural" na 
promoção e defesa de uma vida com mais dignidade, propósito maior dos direitos humanos.

Concluí, assim, que acreditam na resistência política como processo que não se encerrou no passado. Suas vozes me mostraram não só a resistência em face de um Estado que atentou contra suas vidas e os projetos de vida de toda uma nação. Sua resistência seguiu e segue até os dias atuais: ao manterem suas agendas de busca pela verdade das circunstâncias das violações de direitos humanos; ao insistirem na localização e identificação dos desaparecidos políticos; ao denunciarem crimes e criminosos; ao pleitearem reparações e responsabilizações; e, finalmente, ao construírem e promoverem a memória social.

E, mais: resistem ao retomar o espaço de suas vivências de dor para dar-lhe um novo significado; ao reconstituírem suas recordações; ao darem novos sentidos aquelas carceragens; e ao homenagear os que padeceram na luta. E, ainda de modo mais radical, resistem à apatia e à alienação quando chamam os jovens à reflexão e participação política.

Se, ao final, recordar é tornar a passar pelo coração, ouso dizer que o Memorial da Resistência é um local excepcional impregnado de sensibilidades, afetos e lutas, onde as reconstituições de vida gravadas nas paredes e reverberadas nos diálogos com os ex-presos e resistentes políticos ganham sentido. Porque incitam, provocam, incomodam, encantam, emocionam, fazendo da reconstituição das experiências de vida um valioso e potencial instrumento de, não só olhar o passado, mas transformar o presente, e buscar melhores caminhos futuros.

Por fim, contra o legado de violações construído ao largo das últimas décadas, as narrativas que me foram aqui compartilhadas e o trabalho desenvolvido no Memorial, me fazem confiar na construção real e possível de um redentor legado da resistência. 


\section{REFERÊNCIAS}

ABRÃO, Paulo; TORELLY, Marcelo. As razões da eficácia da Lei de Anistia no Brasil e as Alternativas para a Verdade e a justiça em relação às graves violações de direitos humanos ocorridas durante a ditadura militar (1964 - 1985). In.: PRADO, Alessandro Martins;BATISTA, Cláudia Karina Ladeia;SANTANA, Isael José (Orgs.).Direito à Memória e à Verdade e Justiça de Transição no Brasil: uma história inacabada! Uma República inacabada!. 1.ed. Curitiba: CRV, 2011. p. 189-234.

ABRÃO, Paulo et. al. Educação e Anistia Política: idéias e práticas emancipatórias para a construção da memória, da reparação e da verdade no Brasil. In:Repressão e Memória Política no Contexto íbero-Brasileiro: Estudos sobre Brasil, Guatemala, Moçambique, Peru e Portugal. Brasília: Ministério da Justiça, Comissão de Anistia; Portugal: Universidade de Coimbra, Centro de Estudos Sociais, 2010. p. 60-87

ADORNO, Sergio. As raízes históricas e sociais da violência no Brasil.Canal do Núcleo de Estudos da Violência - NEV-USP. [28 jan. 2015]. Disponível em: <https://www.youtube.com/watch?v=PkTdCtZReX8>. Acesso em: 26 jul. 2015.

ALVES, Zélia Maria Mendes Biasoli; SILVA, Maria Helena G. F. Dias da. Análise qualitativa de dados de entrevista: uma proposta. Paidéia, FFCLRP - USP, Rib. Preto, 2, Fev/Jul, 1992. $61-69$.

ARAGÃO, Milena;TIMM, Jordana Wruck;KREUTZ, Lúcio. A história oral e suas contribuições para o estudo das culturas escolares. Conjectura: Filos. Educ., Caxias do Sul, v. 18, n. 2, p. 28-41, maio/ago. 2013.

ARAÚJO, Marcelo Mattos et al. A implantação do programa museológico. In:ARAÚJO, Marcelo Mattos; BRUNO, Maria Cristina Oliveira (Coord.).Memorial da Resistência de São Paulo. São Paulo: Pinacoteca do Estado, 2009. p. 53-97.

. O Memorial em Ação. In:ARAÚJO, Marcelo Mattos; BRUNO, Maria Cristina Oliveira (Coord.).Memorial da Resistência de São Paulo. São Paulo: Pinacoteca do Estado, 2009.

ARQUIDIOCESE DE SÃO PAULO. Brasil: nunca mais. Prefácio de Dom Paulo Evaristo Arns. Petrópolis: Vozes, 1985. 
ARTHUR, Paige. Como as transições reconfiguram os direitos humanos: uma história conceitual da justiça de transição.Justiça de Transição: Manual para a América Latina, Brasília, Ministério da Justiça; Nova lorque: Centro Internacional para Justiça de Transição, 2011. 73-133.

BASTOS, Roberto Gicello. Estações de Ferro: Raphael Martinelli.São Paulo: Pinacoteca do Estado, 2015.

BAUMAN, Zygmunt. Modernidade Líquida. Rio de Janeiro: Jorge Zahar Ed., 2001. p. $199-200$

BENEVIDES, Maria Victoria. Palestra. [2009]. São Paulo: USP, 2009. Cidadania e direitos humanos.Palestra apresentada no Instituto de Estudos Avançados da Universidade de São Paulo. Disponível em:<http://www.iea.usp.br/publicacoes/textos/benevidescidadaniaedireitoshumanos .pdf>. Acesso em: 26 jul. 2015.

BERNARDES, Maria Elena. Memória e Constituição de Espaços de Cidadania. .Fênix - Revista de História e Estudos Culturais. Abril/ Maio/ Junho de 2008. Vol. 5. Ano V. n 2.

BETTO, Frei. Batismo de Sangue. Rio de Janeiro: Editora Rocco, 1983.

BOSI, Ecléa. Memória e Sociedade: lembrançasde velho. 2 ed. São Paulo: T. A. Queroz: Editora da Universidade de São Paulo, 1987.

O tempo vivo da memória. São Paulo: Ateliê editorial, 2003.

BRASIL. Ato Institucional n. 5, de 13 de dezembro 1968. Decreta a intervenção nos estados e municípios, sem as limitações previstas na Constituição. Disponível em:<http://www.planalto.gov.br/ccivil_03/AIT/ait-05-68.htm>. Acesso em: 26 jul. 2015.

Instituto de Pesquisa Econômica Aplicada. Sistema de Indicadores de Percepção Social (SIPS). Defesa Nacional. Parte III. 19 de janeiro de 2012.Disponível

em:<http://www.ipea.gov.br/portal/images/stories/PDFs/SIPS/120119_sips_mobilid adeurbana.pdf>. Acesso em: 26 jul. 2015. 
Lei n. 10.559, de 13 de novembro2002. Disponível em: <http://www.planalto.gov.br/ccivil_03/leis/2002/L10559.htm>. Acesso em: 26 jul. 2015.

Lei n. 9.140, de 04 de dezembro1995. Disponível em: <http://www.planalto.gov.br/CCIVIL_03/LEIS/L9140.htm>. Acesso em: 26 jul. 2015.

- Livro do votos da Comissão de Anistia: verdade e reparação aos perseguidos políticos do Brasil. Brasília: Ministério da Justiça; Florianópolis: Instituto Primeiro Plano, 2013.

Relatório da Comissão Nacional da Verdade. Brasília: CNV, 2014. v. 1, p. 976.Disponível em: <http://www.cnv.gov.br/images/pdf/relatorio/volume_1_digital.pdf>. Acesso em: 01 jun. 2015.

Secretaria de Direitos Humanos da Presidência da República. Programa Nacional de Direitos Humanos (PNDH-3). p. 185-306. Disponível em:<http://www.sdh.gov.br/assuntos/direito-para-todos/programas/pdfs/programanacional-de-direitos-humanos-pndh-3>. Acesso em: 26 jul. 2015.

Supremo Tribunal Federal. Arguição de Descumprimento de Preceito Fundamental n. 153, de 28 de abril de 2010. Disponível em:<http://www.stf.jus.br/arquivo/cms/noticianoticiastf/anexo/adpf153.pdf>. Acesso em: 26 jul. 2015.

BRESCIANI, Maria Stella Martins. As intrínsecas e (im) possíveis relações entre memória e história. Revista da Anistia Política e Justiça de Transição / Ministério da Justiça. - N. 5 (jan. / jun. 2011). - Brasília : Ministério da Justiça , 2012. 16-27.

BRITO, Alexandra Barahona. Justiça transicional e uma política de memória: uma visão global. Revista Anistia Política e Justiça de Transição / Ministério da Justiça. - N. 1 (jan. / jun. 2009). -- Brasília : Ministério da Justiça , 2009. 56-83.

BRUNO, Maria Cristina Oliveira; CARNEIRO, Maria Luiza Tucci; AIDAR, Gabriela. Projeto Museológico de Ocupação. A implantação do programa museológico. In: ARAÚJO, Marcelo Mattos; BRUNO, Maria Cristina Oliveira (Coord.).Memorial da Resistência de São Paulo. São Paulo : Pinacoteca do Estado, 2009.p. 42. 
CARDIA, Nancy et al (Coord.). Pesquisa nacional, por amostragem domiciliar, sobre atitudes, normas culturais e valores em relação à violação de direitos humanos e violência: um estudo em 11 capitais de estado. São Paulo: Núcleo de Estudos da Violência da Universidade de São Paulo, 2012. Disponível em: <http://www.nevusp.org/downloads/down264.pdf>. Acesso em: 05 jul. 2012.

CARVALHO, José Murilo de. Cidadania no Brasil: o longo caminho. Rio de Janeiro: Civilização Brasileira, 2013. 16. Ed.

CONDEPE-SP. 20 anos de Condepe-SP. Canal Condepe. [17 jan. 2012]. Disponível em: <https://www.youtube.com/watch?v=D_SUiFC4m5o>. Acesso em: 26 jul. 2015.

CORREAA, Roberto Lobato. Monumentos, política e espaço. Revista eletrônica Scripta Nova. ISSN: 1138-9788. Volume IX, núm. 183, 15 de fevereiro de 2005.

CUNHA, Rosa Maria Cardoso da. Violações de Direitos Humanos na Universidade. In: Relatório da Comissão Nacional da Verdade 2014. Disponível em: $<$ http://www.cnv.gov.br/images/pdf/relatorio/Volume\%202\%20-

\%20Texto\%206.pdf>. Acesso em: 26 jul. 2015.

DAGNINO, Evelina. Sociedade civil, participação e cidadania: de que estamos falando? In: MATO, Daniel (coord.), Políticas de cidadania e sociedade civil em tempos de globalização. Caracas: FACES, Universidade Central de Venezuela, 2004. p. 95-110.

- Os movimentos sociais e a emergência de uma nova noção de cidadania. Anos 90 - Política e sociedade no Brasil. Org. Evelina Dagnino, Ed. Brasiliense, 1994, pág. 103-115.

DE VARINE-BOHAN, Hugues. O museu comunitário é herético? Rio de Janeiro:Associação Brasileira de Ecomuseus e Museus Comunitários, 2005.

. Os princípios da Sociomuseologia a serviço da preservação da memoria da resistência política: uma reflexão sobre as metodologias aplicadas ao projeto. In: ARAÚJO, Marcelo Mattos; BRUNO, Maria Cristina Oliveira. (Coord.) Memorial da Resistência de São Paulo. São Paulo: Pinacoteca do Estado, 2009. p. 209- 221. 
DELGADO, Lucilia Neves de Almeida. História oral e narrativa: tempo, memória e identidades. HISTÓRIA ORAL, 6, 2003, p. 9-25.

DEOPS. Memória do DEOPS. [03 mar. 2010]. Disponível em: <https://www.youtube.com/watch?v=BYvtJNOnwR8 >. Acesso em: 26 jul. 2015.

FILHO, José Carlos Moreira. Dever de memória e a construção da história viva: a atuação da Comissão de Anistia do Brasil na concretização do direito à memória e à verdade. In:Repressão e Memória Política no Contexto Íbero-Brasileiro: Estudos sobre Brasil, Guatemala, Moçambique, Peru e Portugal. Brasília: Ministério da Justiça, Comissão de Anistia; Portugal: Universidade de Coimbra, Centro de Estudos Sociais, 2010. p. 186-227.

FIORUCCI, Rodolfo. História oral, Memória, História. Revista História em Reflexão: Vol. 4 n. 8 - UFGD - Dourados jul/dez 2010.

FLORES, Joaquin Herrera. A (re) invenção dos direitos humanos. Trad. Carlos Roberto Diogo Garcia, Antonio H. G. Suxberger e Jefferson A. Dias. Florianópolis: Fundação Boiteux, 2009.

GANDON, Tânia. Entre memória e história: tempo múltiplo de discursos e muitas vozes. São Paulo: Proj. História , 2001. p. 139-155.

GENRO, Tarso; ABRÃO, Paulo. Memória Histórica, Justiça de Transição e Democracia sem Fim. In:Repressão e Memória Política no Contexto ÍberoBrasileiro: Estudos sobre Brasil, Guatemala, Moçambique, Peru e Portugal. Brasília: Ministério da Justiça, Comissão de Anistia; Portugal: Universidade de Coimbra, Centro de Estudos Sociais, 2010. p. 16-24.

GOHN, Maria da Glória. Movimentos Sociais e Redes de Mobilizações Contemporâneo. Petrópolis: Vozes, 2010.

GONÇALVES, Rita de Cássia; LISBOA, Teresa Kleba. Sobre o método da história oral em sua modalidade trajetórias de vida. Rev. Katál. Florianópolis v. 10 n. Esp. p. 83-92. 2007.

GOULART, Elias Estevão; PERAZZO, Priscila Ferreira; LEMOS, Vilma. Memória e 
cidadania nos acervos de história oral e mídia digital. Em Questão, Porto Alegre, v. 11, n. 1, p. 153-166, jan./ jun. 2005.

GUMIERI, Julia Cerqueira. Espaços de memória: uma luta por memória, verdade e justiça no Brasil e na Argentina. Em Tempo de Histórias.Publicação do Programa de Pós-Graduação em História da Universidade de Brasília (PPGHIS/UnB) №. 20, Brasília, jan. - jul. 2012. ISSN 2316-1191. p. 49-74.

HALBWACHS, Maurice. A Memória Coletiva. São Paulo: Centauro, 2003.

HUYSSEN, Andreas. Culturas do passado-presente: modernismo, artes visuais, políticas da memória. Rio de Janeiro : Contraponto, 2014. 1.ed.

INSTITUTO DE ESTUDOS SOBRE A VIOLÊNCIA DE ESTADO; COMISSÃO DE FAMILIARES DE MORTOS E DESAPARECIDOS POLÍTICOS. Dossiê Ditadura: Mortos e Desaparecidos Políticos no Brasil (1964-1985). São Paulo: Imprensa Oficial do Estado de São Paulo, 2009.2ª ed.ver. ampl. e atualizada.p. 23.

INSTITUTO DE POLÍTICAS PÚBLICAS EM DIREITOS HUMANOS DO MERCOSUL (IPPDH). Principios Fundamentales sobre Sitios de Memoria, XXII Reunião de Altas Autoridades em Direitos Humanos e Chancelarias do Mercosul e Estados Associados (RAADH), 2012, Porto Alegre. Disponível em: $<$ http://www.ippdh.mercosur.int/principios-fundamentales-para-las-politicaspublicas-en-materia-de-sitios-de-memoria/> . Acesso em: 25 jul. 2015.

INTERNATIONAL COUNCIL ON MONUMENTS AND SITES. Declaração de Québec sobre a preservação do "Spiritu loci". Disponível em: <http://www.international.icomos.org/quebec2008/quebec_declaration/pdf/GA16_Q uebec_Declaration_Final_PT.pdf>.Acesso em: 26 jul. 2015.

JELIN, Elizabeth. Cidadania Revisitada: Solidariedade, Responsabilidade e Direitos. In: JELI, Elizabeth; HERSHBERG, Eric (orgs.) Construindo a Democracia: Direitos Humanos, Cidadania e Sociedade na América Latina. São Paulo: EDUSP, 2006. p. 155-179.

JOFFILY, Mariana. No Centro da Engrenagem: os interrogatórios na Operação Bandeirante e no DOI de São Paulo (1969-1975), Rio de Janeiro: Arquivo Nacional, São Paulo: EDUSP, 2013. p.43. 
JOUTARD, Philippe. Desafios à história oral do século XXI. In. FERREIRA, Marieta de Moraes; FERNANDES, Tânia Maria; ALBERTI, Verena (orgs.). História Oral: desafios para o século XXI. Rio de Janeiro: FGV, 2000, p. 31-45.

KEHL, Maria Rita. A resistência da sociedade civil às graves violações de direitos humanos. In: Relatório da Comissão Nacional da Verdade 2014. Disponível em: $<$ http://www.cnv.gov.br/images/pdf/relatorio/Volume\%202\%20\%20Texto\%209.pdf>. Acesso em: 26 jul. 2015.

LOBO, Elza Ferreira. Documentário Torre das Donzelas: Elza Lobo. [2014]. Disponível em: <http://www.torredasdonzelas.com.br/vozes-da-memoriavideos/elza-lobo/>. Acesso em: 26 jul. 2015.

ElzaFerreira Lobo: entrevista [08 nov. 2014]. Entrevistadora: Viviane

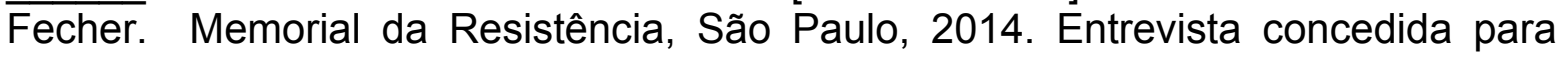
elaboração de dissertação de mestrado do entrevistador.

LOZANO, Carlos; GUILLEROT, Julie. Concepto, fundamentos y opciones para emprender tareas de reparación colectiva y simbólica en Brasil.Bogotá: ICTJ, 2010. Disponível em: <https://www.ictj.org/sites/default/files/ICTJ-BrasilReparations-Options-2010-Spanish.pdf >. Acesso em: 26 jul. 2015.

MEIHY, José Carlos Sebe Bom. Os novos rumos da história oral: o caso brasileiro. Revista de História. 155 (2 - 2006), 191 - 203.

MENEZES, Caroline Grassi Franco; NEVES, Kátia Felipini. O programa museológico e a abertura de novos caminhos preservacionistas e educacionais: rotas para um novo caminho. In: ARAÚJO, Marcelo Mattos; BRUNO, Maria Cristina Oliveira. (Coord.) Memorial da Resistência de São Paulo. São Paulo: Pinacoteca do Estado, 2009.p. 29-38.

MEYER, Eugênia. O fim da memória.Revista Estudos Históricos, Rio de Janeiro, v. 22, n. 43, p. 31-44, jan.-jun. 2009.

MICHAELIS.Dicionário de Português Online.Disponível em: $<$ http://michaelis.uol.com.br/moderno/portugues/index.php?lingua=portuguesportugues\&palavra=resistir>. Acesso em 26 jul. 2015.

NAIDU, Ereshnee. Da Memória à Ação: Um Kit de Ferramentas para 
Memorialização em Sociedades pós-conflito. Brasília:Ministério da Justiça, Comissão de Anistia, 2010.

NOGUEIRA, Rosemary. Documentário Torre das Donzelas: Rose Nogueira. [2014]. Disponível em: <http://www.torredasdonzelas.com.br/vozes-da-memoriavideos/rose-nogueira-2/>. Acesso em: 26 jul. 2015.

Rosemary Nogueira: entrevista [07 nov. 2014]. Entrevistadora: Viviane Fecher. São Paulo, 2014. Entrevista concedida para elaboração de dissertação de mestrado do entrevistador.

NORA, Pierre. Entre memória e História. A problemática dos lugares. Revista Projeto História, São Paulo, v. 10, p. 8, dez. 1993.

OLIVEIRA, Almir Almeida de. Observação e entrevista em pesquisa qualitativa. Revista FACEW. Vila Velha. N. 4. Jan./ Jun. 2010. p. 22-27.

ORGANIZAÇÃO DAS NAÇÕES UNIDAS. O Estado de Direito e a justiça de transição em sociedades em conflito ou pós-conflito. Revista Anistia Política e Justiça de Transição, Brasília, Ministério da Justiça, n. 1, p. 320-351, jan.-jun. 2009.

ORGANIZAÇÃO DOS ESTADOS AMERICANOS. Corte Interamericana de Direitos Humanos. Sentença no Caso Gomes Lund e outros (Guerrilha do Araguaia) versus Brasil. [24 de novembro de 2010]. Dsiponível em: <http://www.corteidh.or.cr/docs/casos/articulos/seriec_219_por.pdf>. Acesso em: 10 jun.2015.

PADRÓS, Enrique Serra Jorge; VIVAR, Eduardo Enríquez. MEMÓRIAS DA RESISTÊNCIA E DA SOLIDARIEDADE: O Movimento de Justiça e Direitos Humanos contra as ditaduras do Cone Sul e sua Conexão Repressiva. Porto Alegre. $\quad$ ASF-Brasil. 2013.2 Disponível em <http://www2.cddc.vt.edu/marxists/portugues/tematica/livros/diversos/solidariedade. pdf>

PAOLI, Maria Célia. Memória, História e Cidadania: o direito ao passado. In: 0 direito à memória: patrimônio histórico e cidadania. São Paulo: DPH, 1992, p. 25-28. 
PEREIRA, lara Xavier (org.). Rádio Libertadora: a palavra de Carlos Marighella. Brasília: Ministério da Justiça, 2012.

PINSKY, Jaime; PINSKY, Carla Bassanezi (Orgs.). História da Cidadania. 6 ed., São Paulo: Contexto, 2014. p.13.

PINTO, Julio Pimentel. Os muitos tempos da memória. Proj. História, São Paulo, (17), nov. 1988. p.203-211.

POGREBINSCHI, Thamy. O direito de resistência na teoria política contemporânea.In: Revista Lugar Comum, Rio de Janeiro,v. 19-20, p.61-86, 2004.

POLITI, Maurice. Depoimento para a História: A Resistência à Ditadura Militar no Paraná - Dh Paz. [08 fev. 2014]. Disponível em: <https://www.youtube.com/watch?v=r7rw40XWWww>. Acesso em: 26 jul. 2015.

Maurice Politi: entrevista [10 jan. 2015]. Entrevistadora: Viviane Fecher. Memorial da Resistência, São Paulo, 2015. Entrevista concedida para elaboração de dissertação de mestrado do entrevistador.

POLLACK, Michael. Memória, esquecimento, silêncio. In: Revista Estudos Históricos, Rio de Janeiro, v. 2, p. 4, mar. 1989.

- Memória e Identidade Social. In: Revista Estudos Históricos,Rio de Janeiro, v. 5, n. 10, p. 200-212, 1992.

QUINALHA, Renan Honório. Justiça de transição: contornos do conceito. São Paulo : Outras Expressões, 2013. p. 148-149.

RANIERI, Leandro Penna ; BARREIRA, Cristiano Roque Antunes . A entrevista fenomenológica. In: IV Seminário Internacional de Pesquisa e Estudos Qualitativos - SIPEQ, 2010, Rio Claro. Anais do IV Seminário Internacional de Pesquisa e Estudos Qualitativos - SIPEQ, 2010, Disponível em: <http://www.sepq.org.br/IVsipeq/anais/artigos/46.pdf>Acesso em: 15 mar. 2015.

REYES MATE, Manuel. Pensamiento y cultura después del Holocausto. Nuestra Memoria. Año XV · No 32 · Septiembre de 2009. p. 31-38. 
RICOEUR, Paul. A memória, a história, o esquecimento. Campinas: Editora UNICAMP, 2007.

O bom uso das feridas da memória. In: Les résistances sur le Plateau Vivarais-Lignon (1938-1945):Témoins, témoignages et lieux. de mémoires. Les oubliés de l'histoire parlent. Editions du Roure, 2005.

RODEGHERO, Carla Simone; GUAZZELLI, Dante Guimarães; DIENSTMANN, Gabriel.Não calo, grito:Memoria visual da ditadura civil-militar no Rio Grande do Sul. Porto Alegre: Tomo Editorial, 2013. 1.ed.

SANTOS, Cecília Macdowell. Questões de Justiça de Transição: a mobilização dos direitos humanos e a memória da ditadura no Brasil. In:Repressão e Memória Política no Contexto Íbero-Brasileiro: Estudos sobre Brasil, Guatemala, Moçambique, Peru e Portugal. Brasília: Ministério da Justiça, Comissão de Anistia; Portugal: Universidade de Coimbra, Centro de Estudos Sociais, 2010.p. 124-151.

SÃO PAULO. Decreto n. 46.507, de 21 de janeiro de 2002. Disponível em:<http://www.al.sp.gov.br/repositorio/legislacao/decreto/2002/decreto-4650721.01.2002.html>. Acesso em: 26 jul. 2015.

Decreto n. 46.508, de 21 de janeiro de 2002. Disponível em:<http://www.al.sp.gov.br/repositorio/legislacao/decreto/2002/decreto-4650821.01.2002.html>. Acesso em: 26 jul. 2015.

Decreto n. 46.900, de 05 de julho de 2002. Disponível

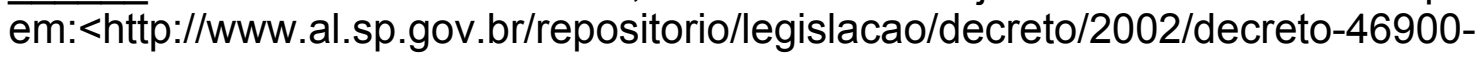
05.07.2002.html>. Acesso em: 26 jul. 2015.

Decreto n. 48.461, de 20 de janeiro de 2004. Disponível em:<http://www.al.sp.gov.br/repositorio/legislacao/decreto/2004/decreto-4846120.01.2004.html>. Acesso em: 26 jul. 2015.

Lei n. 7.576, de 27 de novembro de 1991. Disponível

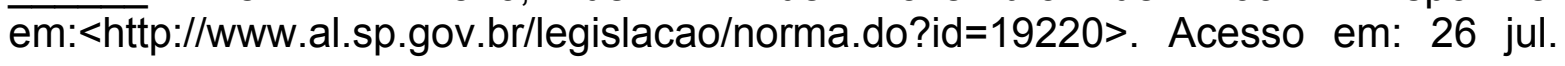
2015. 
SCHERER-WARREN, Ilse. Das mobilizações às redes de movimentos sociais. Revista Sociedade e Estado, Brasília, v. 21, n. 1, p. 109-130, jan.-abr. 2006. Disponível em: <http://www.scielo.br/pdf/se/v21n1/v21n1a07.pdf>. Acesso em: 26 jul. 2015.

SEIXAS, Ivan; POLITI, Maurice. Os elos que vinculam as vivências carcerárias com as perspectivas de comunicação museológica: olhar dos ex-presos politicos. In: ARAÚJO, Marcelo Mattos; BRUNO, Maria Cristina Oliveira. (Coord.) Memorial da Resistência de São Paulo. São Paulo: Pinacoteca do Estado, 2009. p. 199-207.

. Depoimento de IvanSeixas sob o título: Ivan Seixas - Preso e torturado pelo regime militar aos 16 anos. [10 abr. 2014]. Disponível em: <https://www.youtube.com/watch?v=4mt1FVvXdql>. Acesso em: 26 jul. 2015.

Depoimento de IvanSeixas para SBT: Amor e Revolução - Depoimento \#5. [11 abr. 2011]. Disponível em: <https://www.youtube.com/watch?v=w7IXQGOgFS4>. Acesso em: 26 jul. 2015.

IvanAkseirud Seixas: entrevista [08 nov. 2014]. Entrevistadora: Viviane Fecher. Memorial da Resistência, São Paulo, 2014. Entrevista concedida para elaboração de dissertação de mestrado do entrevistador.

SOARES, Inês Virgínia Prado; KISHI, Sandra Akemi Simada. Memória e Verdade: a Justiça de Transição no Estado Democrático Brasileiro. Belo Horizonte: Fórum, 2009. p. 317-355.

TEITEL, Ruti. Genealogia da Justiça Transicional.Justiça de Transição: Manual para a América Latina, Brasília, Ministério da Justiça; Nova lorque: Centro Internacional para Justiça de Transição, 2011. p. 135-170.

TORELLY, Marcelo D. Justiça Transicional, Memória Social e Senso Comum Democrático: notas conceituais e contextualização do caso brasileiro. In:Repressão e Memória Política no Contexto Íbero-Brasileiro: Estudos sobre Brasil, Guatemala, Moçambique, Peru e Portugal. Brasília: Ministério da Justiça, Comissão de Anistia; Portugal: Universidade de Coimbra, Centro de Estudos Sociais, 2010.p. 104-123.

VALDEZ, Patricia Tappatá de. Cuando nada es suficiente. In: TOSI, Giuseppe et al (Orgs.) .Justiça de transição: direito à justiça, memória e à verdade. João Pessoa: Editora da UFPB, 2014. p. 25-38. 
ZYL, Paul Van. Promovendo a Justiça Transicional em sociedades pósconflito.Justiça de Transição: Manual para a América Latina, Brasília, Ministério da Justiça; Nova lorque: Centro Internacional para Justiça de Transição, 2011. p. 47-71.

\section{SÍTIOS ELETRÔNICOS NA REDE MUNDIAL DE COMPUTADORES:}

1.Brasil Nunca Mais Digital: www.bnmdigital.mpf.mp

2.Centro Internacional de Justiça de Transição - ICTJ: www.ictj.org

3.Cidade de São Paulo: www.cidadedesaopaulo.com

4.Comissão Nacional da Verdade : www.cnv.gov.br

5.Comitê da Verdade de Porto Alegre <https://comitedaverdadeportoalegre.wordpress.com/campanhas/>.

6.Conselho Internacional de Monumentos e Sítios - ICOMOS: www.icomos.org

7.Corte Interamericana de Direitos Humanos: <http://www.cddh.org.br/>.

8.Fórum de Ex-presos e Perseguidos Políticos de São Paulo: www. forumexpresospoliticossp.files.wordpress.com

9.Grupo Tortura Nunca Mais - GTNM -RJ <http://www.torturanuncamaisrj.org.br/jornal/gtnm_74/memoria.html>.

10.Grupo Tortura Nunca Mais SP- GTNM-SP: www.torturanuncamais-sp.org

11.Instituto de Estudos da Religião - ISER: www.iser.org.br

12.Memorial da Resistência: www.memorialdaresistênciasp.org.br

13.Núcleo Memória: www.nucleomemoria.org.br

14.Ordem dos Advogados do Brasil - SP <http://www.oabsp.org.br/noticias/2013/08/06/espera-inaugurar-o-memorial-da-lutapela-justica-no-proximo-ano-1/>.

15.Pinacoteca de São Paulo: www.pinacoteca.org.br

16.Sites of Conscience <http://www.sitesofconscience.org/pt-br/membros/>. 


\section{ANEXO}

\section{GUIA DE ENTREVISTA}

Guia de questões para as entrevistas com ex-presos políticos que participaram do processo de formação do Memorial da Resistência, parte integrante da pesquisa para dissertação em nível de Mestrado do Programa de Pós-graduação em Direitos Humanos e Cidadania do Centro de Estudos Avançados Multidisciplinares da Universidade de Brasília.

\section{1) Dados de identificação:}

- qualificação, idade, profissão, escolaridade, onde vive e etc.

\section{2) Experiência durante a ditadura:}

- narrar um pouco de sua experiência durante a ditadura - militância; violações e filiação partidária;

- como percebe o tempo decorrido até a iniciativa do Estado em criar o memorial;

- qual o sentido de transformar um local de violação em espaço de memória;

3) Sobre o processo de formação do Memorial da Resistência:

- por qual motivo decidiu participar do processo de criação do Memorial(buscar percepções tais como: significado político, cunho moral, político, afetivo, revanchista, processo de cura, reparação, reconciliação e etc.);

-que tipo de considerações foram consideradas para esta decisão: crença, concepções de mundo, representações sobre a vida em sociedade e etc.;

- como se deu a decisão de participar (se foi a convite do Estado e etc.); 
- como se deu o processo de transformação do prédio do DEOPS/SP no Memorial (buscar percepções tais como dificuldades encontradas, envolvimento dos agentes de Estado e etc.);

- como se deu a participação do(a) entrevistado(a) na formação do Memorial (ativa; propositiva; consultoria; nível decisório e etc.);

- como era a rotina de trabalhados no processo de formação do Memorial;

- qual sentido atribui à sua participação na criação do Memorial (buscar percepções tais como orgulho, satisfação, arrependimento, decepção etc.);

- se atribui à sua participação na criação do Memorial como direito e/ou dever;

- se percebe que sua atuação na construção do Memorial foi representativa de um grupo ou movimento;

- se sim, explorar mais as caraterísticas desse grupo ou movimento;

- se viu suas demandas contempladas no projeto;

- se foi a primeira vez que teve participação na construção de uma política em conjunto com o Estado;

- como percebe essa relação sociedade civil e Estado na realização de uma política pública (percebeu como parceria; "projeto participativo democratizante"447; relação equilibrada; relação de submissão e etc.);

- como percebe/avalia a atuação do Estado no processo de construção do Memorial;

447Expressão utilizada por Evelina Dagnino, designa um processo iniciado ainda durante a resistência ao regime militar, baseado na "ampliação da cidadania e na participação da sociedade civil". p. 98-99 


\section{4) Sobre o Memorial da Resistência}

- qual a compreensão do(a) entrevistado(a) sobre memória coletiva;

- se tem compreensão de que a memória é um direito;

- o que entende por cidadania;

- qual a compreensão do(a) entrevistado(a) sobre os "lugares de memória";

- se tem compreensão de que preservar a memória é um dever do Estado;

- que sentido o(a) entrevistado(a) atribui ao Memorial(reparação, homenagem, espaço político);

- qual a expectativa do(a) entrevistado(a) em relação ao Memorial ainda na sua fase de construção;

- se o Memorial correspondeu às suas expectativas depois de inaugurado e, ainda, atualmente;

- se percebe o Memorial como espaço que presentifica suas memórias;

- se o(a) entrevistado(a) participa das atividades realizadas pelo Memorial junto à comunidade; se sim, qual percepção tem de sua participação (direito/dever; construção da memória coletiva e etc.);

- como percebe o papel do Memorial junto à comunidade;

- se percebe o Memorial enquanto espaço gerador de novos direitos e de transformação social;

- se sim, que direitos e que transformações;

- caso tenham alguma foto ou documento que queiram compartilhar.

5) Sobre sua relação com o Memorial

- se percebe como agente político transformador;

- se percebe fortalecendo um projeto; 
- se sua proximidade com o Memorial modificou sua relação com o Estado, outrora violador de direitos humanos e, agora, promotor de políticas de memória (buscar percepções tais como reconciliação, cura, revolta, tristeza, decepção e etc.);

- se sim, o que mudou nesta relação;

- como avalia sua atuação junto com o Estado (pontos positivos; pontos negativos; arrependimento; satisfação e etc.);

6) Trabalhar percepções durante a entrevista: repetições; pausas; olhares; mãos; expressões faciais; expressões linguísticas; vocabulário; emoções e etc. 